\title{
Idaho National Engineering and Environmental Laboratory Site Environmental Report for Calendar Year 1997
}

Roy B. Evans

Donny Roush
Ron W. Brooks

Don B. Martin
BECEIVED

DEC 272000

OSTI

Environmental Science and Research Foundation, Inc.

Doyle Markham, Executive Director

B. Sue Lantz

U.S. Department of Energy-Idaho Operations Office

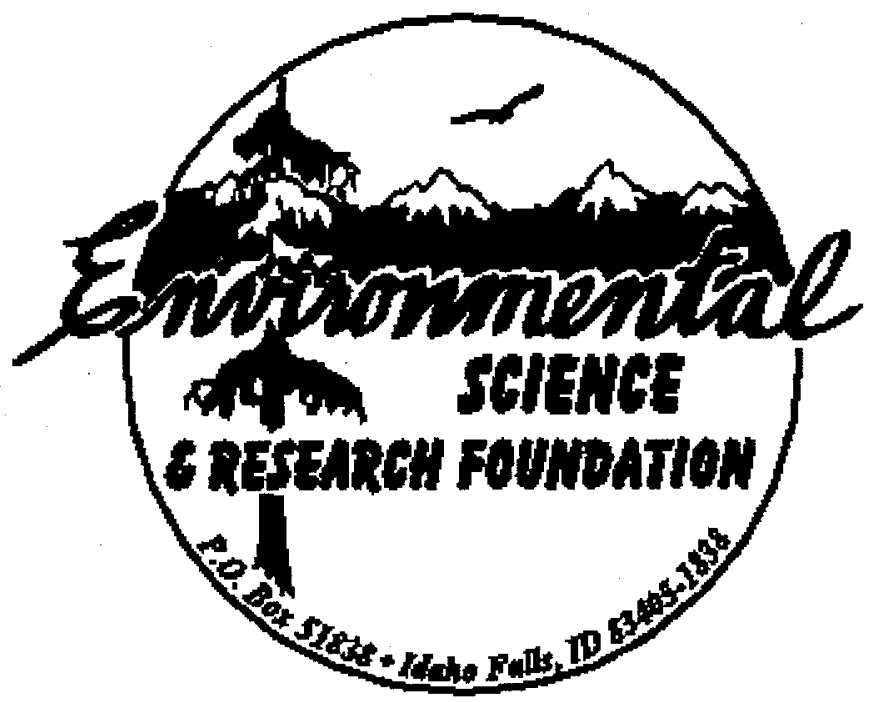

Report was prepared for the U.S. Department of Energy-Idaho Operations Office under Contract DE-AC07-94ID13268 by the Environmental Science and Research Foundation, Inc.

101 S. Park Avenue, Suite 2; PO Box 51838 Idaho Falls, Idaho 83405-1838 


\section{DISCLAIMER}

This report was prepared as an account of work sponsored by an agency of the United States Government. Neither the United States Government nor any agency thereof, nor any of their employees, make any warranty, express or implied, or assumes any legal liability or responsibility for the accuracy, completeness, or usefulness of any information, apparatus, product, or process disclosed, or represents that its use would not infringe privately owned rights. Reference herein to any specific commercial product, process, or service by trade name, trademark, manufacturer, or otherwise does not necessarily constitute or imply its endorsement, recommendation, or favoring by the United States Government or any agency thereof. The views and opinions of authors expressed herein do not necessarily state or reflect those of the United States Government or any agency thereof. 


\section{DISCLAIMER}

Portions of this document may be illegible in electronic image products. Images are produced from the best available original document. 


\section{U.S. Department of Energy \\ Idaho National Engineering and Environmental Laboratory}

Environmental Policy June, 1998

The mission of the INEEL as a national laboratory has always necessitated a partnership between our work and our environmental surroundings. As such, we are both a National Laboratory and a National Research Park. The 890 square miles of unique ecosystem that is home to the INEEL has been kept relatively undeveloped and unoccupied throughout our history. These conditions have provided an opportunity to maintain the quality of this unique ecosystem while conducting valuable scientific research in both energy and environmental areas.

In continuing this legacy, it is the policy of the INEEL that:

\section{We conduct business and operations in a manner that protects human health and the environment and complies with environmental laws and regulations.}

In support of this policy we:

- Develop, use, and refine environmental management systems for the planning and execution of work.

- Establish documented environmental objectives and targets, and update them as necessary to reflect the changing needs, missions, and goals of the INEEL.

- Continuously improve our activities through critical self-assessment and corrective action.

- Conduct our operations in full compliance with applicable laws, codes and regulations.

- $\quad$ Reduce environmental impacts, costs and compliance liabilities through pollution prevention and recycling.

- $\quad$ Ensure all employees understand the environmental impacts of their work.

- Work openly with regulators and stakeholders to build and maintain an atmosphere of trust.

Care for the natural resources of the INEEL.

This policy was developed and issued jointly by the Department of Energy field elements for the Idaho National Engineering and Environmental Laboratory. 



\section{PREFACE}

Every person in the world is exposed to ionizing radiation-radiant energy that produces ions as it passes through cells. There are three general types of radiation sources: those of natural origin unaffected by human activities, those of natural origin but enhanced by human activities, and those produced by human activities (anthropogenic).

The first group includes terrestrial radiation from natural radiation sources in the ground, cosmic radiation from outer space, and radiation from radionuclides naturally present in the body. Exposures to natural sources may vary depending on the geographical location, and even the altitude, at which a person resides. When such exposures are substantially higher than the average, they are considered to be elevated.

The second group includes a variety of natural sources from which the radiation has been increased by human actions. For example, radon exposures in a given home may be elevated because of natural radionuclides in the soil and rock on which the house is built; however, the radon exposures of occupants may be enhanced by characteristics of the home, such as extensive insulation. Another example is the increased exposure to cosmic radiation that airplane passengers receive when traveling at high altitudes.

The third group includes a variety of exposures from manmade materials and devices such as medical x-rays, radiopharmaceuticals used to diagnose and treat disease, and consumer products containing minute quantities of radioactive materials. Exposures may also result from radioactive fallout from nuclear weapons testing, accidents at nuclear power plants, and other such episodic events caused by human activities in the nuclear industry. Except for major nuclear accidents, such as the one that occurred at Chernobyl in 1986, exposures to workers and members of the public from activities at nuclear industries are very small compared to exposures from natural sources [Reference P-1].

To verify that exposures resulting from operations at Department of Energy (DOE) nuclear facilities remain very small, each site at which nuclear activities are conducted operates an environmental surveillance program to monitor the air, water and any other pathway whereby radionuclides from operations might conceivably reach workers and members of the public. Environmental surveillance and monitoring results are reported annually to the DOE-Headquarters.

This report presents a compilation of data collected in 1997 for the routine environmental surveillance programs conducted on and around the Idaho National Engineering and Environmental Laboratory (INEEL). During 1997, the offsite surveillance program was conducted by the Environmental Science and Research Foundation. Onsite surveillance was performed by Lockheed Martin Idaho Technologies Company. Effluent monitoring and facility monitoring were conducted by the contractor responsible for operating each facility. The U.S. Geological Survey performed ground-water monitoring both on and offsite, and Lockheed Martin Idaho Technologies Company conducted facility and onsite ground-water monitoring. Air pathways were characterized by the National Oceanic and Atmospheric Administration.

This report, prepared in accordance with the requirements in DOE Order 5400.1, is not intended to cover the numerous special environmental research programs being conducted at the INEEL by the Environmental Science and Research Foundation, Lockheed Martin Idaho Technologies Company, the U. S. Geological Survey, and others [Reference P-2].

Section 9.g of DOE Order 5400.1 exempts the Naval Nuclear Propulsion Program's Naval 
Reactors Facility (NRF) from the provisions of this order and preparation of the Annual Site Environmental Report. The Naval Nuclear Propulsion Program separately maintains an environmental protection program to assure compliance with all applicable environmental laws and regulations. Monitoring data and information specific to NRF are provided in a separate annual environmental report issued by NRF. For completeness, however, some information from onsite monitoring programs at NRF is included in this report.

The Idaho National Engineering and Environmental Laboratory Site Environmental Report for Calendar Year 1997 was prepared by the Environ.. mental Science and Research Foundation under DOE Contract DE-AC97-94ID13268. 


\section{EXECUTIVE SUMMARY}

The results of the various monitoring programs for 1997 indicated that radioactivity from the Idaho National Engineering and Environmental Laboratory (INEEL) operations could generally not be distinguished from worldwide fallout and natural radioactivity in the region surrounding the INEEL. Although some radioactive materials were discharged during INEEL operations, concentrations in the offsite environment and doses to the surrounding population were far less than state of Idaho and federal health protection guidelines.

Chapter 2 of the report summarizes INEEL activities related to compliance with environmental regulations and laws, describes various environmental issues and activities, and summarizes INEEL permits for 1997. Chapter 3 provides a description of major activities and milestones in waste management, environmental restoration, and other environmental programs.

Chapter 4 discusses results from radiological environmental surveillance programs conducted by the Environmental Science and Research Foundation, an independent nonprofit organization, and Lockheed Martin Idaho Technologies Company (LMITCO), the INEEL's maintenance and operations contractor. As part of these programs, samples of air, water, and foodstuffs were collected at distant locations, INEEL boundary locations and onsite locations. Environmental radiation measurements were also made at these locations.

Gross alpha and gross beta measurements, used as a screening technique for air filters, were investigated by making statistical comparisons between onsite or boundary location concentrations and the distant community group concentrations. Gross alpha activities were generally higher at distant locations than at boundary and onsite locations. One LMITCO monthly mean gross alpha activity (EBR-1 for September) was significantly higher than the mean of distant locations for the same time period.
Foundation data indicated statistically significant differences in gross beta activities in $8 \%$ of comparisons of monthly means of onsite locations with the monthly distant group means. Comparisons of monthly mean gross beta activities measured onsite by LMITCO with the monthly means measured by LMITCO at distant locations found statistically significant differences in $11 \%$ of cases. In comparisons of monthly means, onsite stations were higher than distant stations in April and June in Foundation data. Onsite stations were higher than distant stations in August for LMITCO data. At least some of these statistical differences may have been related to operations at the INEEL, but no source could be identified.

Air samples were also analyzed for specific radionuclides. Some manmade radionuclides were detected at offsite locations, but most were near the minimum detectable concentration and their presence was attributable to natural sources, worldwide fallout, and statistical variations in the analytical results rather than to INEEL operations.

Americium-241 was detected in several Foundation air samples during the year. The Foundation is currently investigating the high incidence of these detections but has reached no conclusions at this time. The annual concentrations of all specific nuclides detected at all locations were well below the DOE's derived concentration guides for radiation protection.

Tritium was detected in some atmospheric moisture and precipitation samples, but concentrations were similar at distant, boundary, and onsite locations indicating that these detections were likely due to natural production in the upper atmosphere rather than to INEEL activities.

Gross alpha and gross beta activity were measured in offsite drinking and surface water samples. Concentrations were within the range expected for natural radioactivity. One offsite water sample 
contained a tritium concentration just above the minimum detectable concentration, attributable to fallout sources or statistical variations.

Two milk samples contained ${ }^{131} \mathrm{I}$ at levels just above the minimum detectable concentration. Tritium was not detected in any milk sample in 1997. Seven samples contained detectable concentrations of ${ }^{90} \mathrm{Sr}$. These concentrations were consistent with levels seen in samples nationwide, as reported by the Environmental Protection Agency (EPA). Some food samples (lettuce, wheat, and potatoes) contained small amounts of ${ }^{137} \mathrm{Cs}$ and ${ }^{90} \mathrm{Sr}$, two radionuclides deposited by worldwide fallout which are found in soil.

Low concentrations of ${ }^{137} \mathrm{Cs}$ were found in muscle tissue and liver of some game animals and sheep. These levels were mostly consistent with background concentrations measured in animals sampled onsite and offsite in recent years. Two pronghorns accidentally killed on INEEL highways had detectable ${ }^{137} \mathrm{Cs}$ in muscle tissue. Anthropogenic radionuclides were also found in above-background concentrations in waterfowl and doves collected near the Test Reactor Area. The potential dose to a hunter consuming game with the highest concentration of radionuclides was calculated to be approximately $1.4 \mathrm{mrem}$, or $0.4 \%$ of annual background radiation.

Ionizing radiation measured simultaneously at the INEEL boundary and distant locations using environmental dosimeters were similar and showed only background levels.

Both the Environmental Science and Research Foundation and LMITCO also perform environmental surveillance for nonradiological substances. Chapter 5 presents a summary of air and storm water sampling results from the INEEL and offsite locations.

As in most previous years, total suspended particulate concentrations in air were generally higher at distant and boundary locations than at onsite locations. Agricultural activities are generally considered to be the major source of par-ticulates in eastern Idaho. Annual onsite particulate concentrations were lower than in other recent years

Fine particulates, nitrogen dioxide, and sulfur dioxide measured on and in the vicinity of the INEEL were all well within air quality standards. Levels of one or more parameters in storm water were above the corresponding EPA benchmarks at three monitoring points. However, no storm water discharge from INEEL facilities reached any permanent surface streams.

Ground-water monitoring was performed at the INEEL by the USGS using over 125 wells that tap the Snake River Plain Aquifer, as described in Chapter 6. Results of a number of special studies of the properties of the aquifer and the water within it were published during 1997. Several purgeable organic compounds (POC's) continue to be found in wells at the INEEL. One well used for drinking water contained POC's. At all but three wells, concentrations of organic compounds were below the USEPA maximum contaminant levels (MCLs) for these compounds. In one monitoring well and one production well at the Radioactive Waste Management Complex (RWMC), concentrations of carbon tetrachloride slightly exceeded the MCL. One sample from a low-yielding well completed in a perched ground-water zone at the RWMC also showed substantial concentrations of carbon tetrachloride, chloroform, tetrachloroethylene, and trichloroethylene which exceeded the corresponding MCLs. (Throughout this report, measured concen-trations of contaminants in ground water and surface water are compared to the corresponding USEPA drinking water standards as benchmarks. The EPA drinking water MCLs apply only to water being consumed by at least 25 people on a nontransient basis. For any other water source, the MCLs are cited for comparison purposes only.)

Routine monitoring of ground water was also conducted by contractors operating facilities at the INEEL. Five onsite production (drinking water) wells contained measurable concentrations of 
tritium. An effective dose equivalent of 0.6 $\mathrm{mrem} / \mathrm{yr}$, within the EPA standard for community drinking water, was calculated for INEEL workers at the Central Facilities Area, the location with the highest tritium concentration in drinking water.

Production wells in the vicinity of the Idaho Nuclear Technology and Engineering Center (formerly the Idaho Chemical Processing Plant), where ${ }^{90} \mathrm{Sr}$ monitoring is performed regularly because this radionuclide is known to be present, did not contain detectable levels of ${ }^{90} \mathrm{Sr}$ in 1997.

Water samples, taken from the wellhead at one Test Area North well, showed purgeable organic compounds were above the maximum contaminant level for trichlorethylene. At Test Area North, an aerating system known as a sparger is used to volatilize the trichloroethylene and remove it prior to the water entering the distribution system. This has resulted in organic compounds remaining less than drinking water standards in the distribution system.

Chapter 7 presents a description of the monitoring of airborne and liquid effluents released from INEEL facilities during 1997. An estimated total of 5,595 curies of radioactivity, primarily in the form of noble gases, were released as airborne effluents. Approximately 100 curies of radioactivity, mostly tritium, were released to onsite disposal ponds during the year.

A total of 828 metric tons of nitrogen oxide and nitrogen dioxide and 96 metric tons of sulfur dioxide were released from INEEL facilities. Nitrogen dioxide and sulfur dioxide concentrations, calculated for the INEEL boundary using meteorological models and measured at onsite locations, were well below air quality regulatory limits. Monitoring of liquid effluent streams indicated that all were below applicable guidelines.

Chapter 8 describes the potential dose to members of the public from INEEL activities. The calculated hypothetical maximum individual effective dose equivalent of $0.02 \mathrm{mrem}\left(2 \times 10^{-4} \mathrm{mSv}\right)$ was found to occur near Howe, Idaho. This calculation was performed with MDIFF, a computer model developed to evaluate dispersion of pollutants from INEEL facilities. The calculation considered continuous submersion in and inhalation of radioactivity in air, ingestion of radioactivity in leafy vegetables and milk, and exposure to radioactive particulates deposited on the ground surface at that location on a continuous, year-round basis. This calculated dose is about $0.006 \%$ of the background radiation dose in this area from all sources, including cosmic radiation, radioactive material in soil, natural radioactive potassium in the body, and exposure to radon

The 1997 effective dose equivalent to the maximally exposed individual, calculated using the CAP-88 computer code required for demonstration of compliance with EPA regulations, was 0.03 mrem $(0.008 \%$ of background). The model predicted the maximally exposed individual resided at Frenchman's Cabin, located at the INEEL's southern boundary. This location is currently inhabited only during portions of the year. The section entitled "Maximum Individual Dose-Airborne Emissions Pathway" includes a discussion of the two different computer models used. The maximum calculated dose to an individual by either of the methods was in compliance with the applicable radiation protection standards of 10 mrem per year.

The maximum potential population dose from submersion, ingestion, inhalation, and deposition to the approximately 121,500 people residing within an $80-\mathrm{km}(50-\mathrm{mi})$ radius from the geographical center of the INEEL was estimated to be 0.2 person-rem $\left(2 \times 10^{-3}\right.$ person-Sv) using the MDIFF air dispersion model. This population dose is less than $0.0005 \%$ of the estimated 43,700 person-rem ( 437 person-Sv) population dose from background radioactivity.

In Chapter 9, the methods used to ensure the quality of data generated by contractors performing environmental monitoring at the INEEL are described. Data from quality control samples, including duplicate samples (two similar samples collected at the same time) and spiked samples 
(samples containing a known amount of a contaminant) are provided. Comparisons are also provided between data collected by the Environmental

Science and Research Foundation, LMITCO and the state of Idaho INEEL Oversight Program at locations where the three groups conduct similar sampling. 


\section{HELPFUL INFORMATION}

\section{Scientific Notation}

Scientific notation is used to express numbers which are very small and very large. A very small number will be expressed with a negative exponent, for example, $1.3 \times 10^{-6}$. To convert this number to the more commonly used form, the decimal point must be moved left by the number of places equal to the exponent ( 6 , in this case). The number thus becomes 0.0000013 .

For large numbers, those with a positive exponent, the decimal point is moved to the right by the number of places equal to the exponent. The number $1,000,000$ (or one million) can be written as $1.0 \times 10^{6}$.

\section{Unit Prefixes}

Units for very small and very large numbers are commonly expressed with a prefix. One example is the prefix kilo (abbreviated $\mathrm{k}$ ), which means 1,000 of a given unit. A kilometer is therefore equal to 1,000 meters. Other prefixes used in this report are:

\begin{tabular}{cc} 
Prefix & Abbreviation \\
\hline Mega- & $\mathrm{M}$ \\
centi- & $\mathrm{c}$ \\
milli- & $\mathrm{m}$ \\
micro- & $\mu$ \\
nano- & $\mathrm{n}$ \\
pico- & $\mathrm{p}$
\end{tabular}

\author{
Meaning \\ $1,000,000\left(=1 \times 10^{6}\right)$ \\ $1 / 100\left(=1 \times 10^{-2}\right)$ \\ $1 / 1,000\left(=1 \times 10^{-3}\right)$ \\ $1 / 1,000,000\left(=1 \times 10^{-6}\right)$ \\ $1 / 1,000,000,000\left(=1 \times 10^{-9}\right)$ \\ $1 / 1,000,000,000,000\left(=1 \times 10^{-12}\right)$
}

\section{Units of Radioactivity, Radiation Exposure and Dose}

The basic unit of radioactivity used in this report is the curie (abbreviated $\mathrm{Ci}$ ). The curie was historically based on the radionuclide radium-226, of which one gram decays at the rate of 37 billion nuclear disintegrations per second. For any other radionuclide, one curie is the amount of the radionuclide that decays at this same rate.

Radiation exposure is expressed in terms of the Roentgen ( $R$ ), the amount of ionization produced by gamma radiation in air. Dose is given in units of "Roentgen equivalent man" or rem, which takes into account the effect of radiation on tissues. For the types of environmental radiation generally encountered, the unit of Roentgen is approximately numerically equal to the unit of rem. A person-rem is the sum of the doses received by all individuals in a population.

Concentration of radioactivity in air samples and liquid samples such as water and milk is expressed in units of microcuries per milliliter $(\mu \mathrm{Ci} / \mathrm{mL})$ of air or liquid. Radioactivity in foodstuffs is expressed in microcuries per gram $(\mu \mathrm{Ci} / \mathrm{g})$. Annual human radiation exposure, measured by environmental dosimeters, is 
expressed in units of milliRoentgens (mR). This is sometimes expressed in terms of dose as millirem (mrem), after being multiplied by an appropriate dose equivalent conversion factor.

The Système International is also used to express units of radioactivity and radiation dose. The basic unit of radioactivity is the Becquerel $(\mathrm{Bq})$, which is equivalent to one nuclear disintegration per second. The number of curies must be multiplied by $3.7 \times 10^{10}$ to obtain the equivalent number of Becquerels. Doses may also be expressed using the Système International unit Sievert (Sv), where 1 Sievert equals 100 rem.

\section{Uncertainty of Measurements}

There is always an uncertainty associated with the measurement of environmental contaminants. For radioactivity, the predominant source of uncertainty is the inherent statistical nature of radioactive decay events, particularly at the low activity levels encountered in environmental samples. The uncertainty of a measurement is denoted by following the result with a " \pm " (uncertainty) term. This report follows convention in reporting the uncertainty as a $95 \%$ confidence limit (or interval). That means there is about $95 \%$ confidence that the real concentration in the sample lies somewhere between the measured concentration minus the uncertainty term and the measured concentration plus the uncertainty term.

\section{Negative Numbers as Results}

Negative values occur when the measured result is less than a preestablished average background level for the particular counting system and procedure used. These values, rather than "not detectable" or "zero," are reported to better enable statistical analyses and observe trends or bias in the data.

\section{Radionuclide Nomenclature}

Radionuclides are frequently expressed with the one- or two-letter chemical symbol for the element. Radionuclides may have many different isotopes, which are shown by a superscript to the left of the symbol. This number is the atomic weight of the isotope (the number of protons and neutrons in the nucleus of the atom). Radionuclide symbols used in this report are shown in the following table.

\begin{tabular}{lrlr} 
Radionuclide & Symbol & Radionuclide & $\underline{\text { Symbol }}$ \\
\hline Tritium & ${ }^{3} \mathrm{H}$ & Iron-55 & ${ }^{55} \mathrm{Fe}$ \\
Beryllium-7 & ${ }^{7} \mathrm{Be}$ & Manganese-56 & ${ }^{56} \mathrm{Mn}$ \\
Carbon-14 & ${ }^{14} \mathrm{C}$ & Cobalt-57 & ${ }^{57} \mathrm{Co}$ \\
Sodium-24 & ${ }^{24} \mathrm{Na}$ & Cobalt-58 & ${ }^{58} \mathrm{Co}$ \\
Potassium-40 & ${ }^{40} \mathrm{~K}$ & Iron-59 & ${ }^{59} \mathrm{Fe}$ \\
Argon-41 & ${ }^{41} \mathrm{Ar}$ & Cobalt-60 & ${ }^{60} \mathrm{Co}$ \\
Scandium-46 & ${ }^{46} \mathrm{Sc}$ & Zinc-65 & ${ }^{65} \mathrm{Zn}$ \\
Chromium-51 & ${ }^{51} \mathrm{Cr}$ & Krypton-85 & ${ }^{85} \mathrm{Kr}$ \\
Manganese-54 & ${ }^{54} \mathrm{Mn}$ & &
\end{tabular}




\section{Radionuclide Nomenclature (Cont.)}

Radionuclide

Krypton-87

Krypton-88

Rubidium-88

Strontium-90

Yttrium-90

Niobium-94

Niobium-95

Zirconium-95

Technetium-99

Ruthenium-103

Ruthenium-106

Antimony-125

Iodine-129

Iodine-131

Iodine-132

Iodine-133

Xenon-133

Cesium-134
Symbol

${ }^{87} \mathrm{Kr}$

${ }^{88} \mathrm{Kr}$

${ }^{88} \mathrm{Rb}$

${ }^{90} \mathrm{Sr}$

${ }^{90} \mathrm{Y}$

${ }^{94} \mathrm{Nb}$

${ }^{95} \mathrm{Nb}$

${ }^{95} \mathrm{Zr}$

${ }^{99} \mathrm{Tc}$

${ }^{103} \mathrm{Ru}$

${ }^{106} \mathrm{Ru}$

${ }^{125} \mathrm{Sb}$

${ }^{129} \mathrm{I}$

${ }^{131} \mathrm{I}$

${ }^{132} \mathrm{I}$

${ }^{133} \mathrm{I}$

${ }^{133} \mathrm{Xe}$

${ }^{134} \mathrm{Cs}$
Radionuclide

Xenon-135

Cesium-137

Cesium-138

Xenon-138

Barium-140

Cerium-144

Europium-152

Hafnium-181

Radium-226

Radium-228

Thorium-232

Uranium-234

Uranium-238

Plutonium-238

Plutonium-239/240

Americium-241

Curium-244

$$
\begin{gathered}
\frac{\text { Symbol }}{{ }^{135} \mathrm{Xe}} \\
{ }^{137} \mathrm{Cs} \\
{ }^{138} \mathrm{Cs} \\
{ }^{138} \mathrm{Xe} \\
{ }^{140} \mathrm{Ba} \\
{ }^{144} \mathrm{Ce} \\
{ }^{152} \mathrm{Eu} \\
{ }^{181} \mathrm{Hf} \\
{ }^{226} \mathrm{Ra} \\
{ }^{228} \mathrm{Ra} \\
{ }^{232} \mathrm{Th} \\
{ }^{234} \mathrm{U} \\
{ }^{238} \mathrm{U} \\
{ }^{238} \mathrm{Pu} \\
{ }^{239 / 240} \mathrm{Pu} \\
{ }^{241} \mathrm{Am} \\
{ }^{244} \mathrm{Cm}
\end{gathered}
$$




\section{ACRONYMS}

AEC

Atomic Energy Commission

ANL-W

ARA

CERCLA Comprehensive Environmental

Response, Compensation, and

Liability Act

CDC

CFA

CFR

CFSGF

CMS

CWA

DEQ

DOE

DOE-CH

DOE-ID

DOE-HQ

EAL

EBR-I

EFS

Argonne National

Laboratory-West

Central Facilities Area

Code of Federal Regulations

Coal Fired Steam Generating

Facility

Clean Water Act Quality

U.S. Department of Energy

U.S. Department of

Energy-Chicago Operations

Office

Operations Office

U.S. Department of

Energy-Headquarters

Environmental Assessment

Laboratory

Experimental Field Station
Community Monitoring Station

(Idaho) Division of Environmental

U.S. Department of Energy-Idaho

Experimental Breeder Reactor-I
EMS

EPCRA

EPA

HLW

IMPROVE

INTEC

LLW

LMAES

Environmental Measurements

Laboratory

Environmental Management

System

Emergency Planning and

Community Right-to-Know Act

Environmental Protection

Agency

High-level [radioactive] waste

Idaho Chemical Processing Plant (now Idaho Nuclear Technology and Engineering Center, or INTEC)

Interagency Monitoring of Protected Visual Environments

Idaho National Engineering and Environmental Laboratory

Idaho Nuclear Technology and Engineering Center (formerly Idaho Chemical Processing Plant, or ICPP)

Low-level [radioactive] waste

Lockheed Martin Advanced

Environmental Systems

LMITCO Lockheed Martin Idaho

Technologies Company

$\mathrm{MCL}$

Maximum Contaminant Level

MSDS

Material Safety Data Sheet

NCRP

National Council on Radiation

Protection and Measurements 
NEPA National Environmental Policy Act

NERP

National Environmental Research

Park

NESHAPs National Emission Standards for

Hazardous Air Pollutants

NIST National Institute of Standards and

Technology

NOAA National Oceanic

and Atmospheric Administration

NOV Notice of Violation

NPDES National Pollutant Discharge

Elimination System

NRF

NRTS National Reactor Testing Station

PBF Power Burst Facility

PCBs Polychlorinated Biphenyls

PFA Plutonium Focus Area

QAP : Quality Assessment Program

RCRA Resource Conservation and

Recovery Act

RESL Radiological and Environmental

Sciences Laboratory

RWMC Radioactive Waste Management

Complex

RWMIS Radioactive Waste Management

Information System

SMC
SWPPP

TAN

TLD

TRA

TRU

TSF

USGS

WERF

WIPP
Storm Water Pollution

Prevention Plan

Test Area North

Thermoluminescent Dosimeter

Test Reactor Area

Transuranic

Technical Support Facility

U.S. Geological Survey

Waste Experimental Reduction Facility

Waste Isolation Pilot Plant 


\section{CONTENTS}

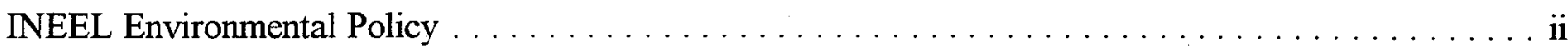

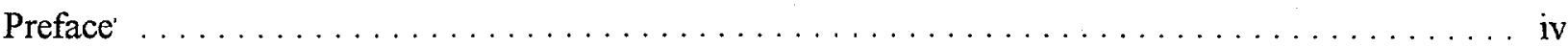

Executive Summary $\ldots \ldots \ldots \ldots \ldots \ldots \ldots \ldots \ldots \ldots \ldots \ldots \ldots \ldots \ldots \ldots \ldots \ldots \ldots$

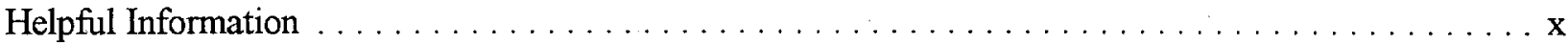

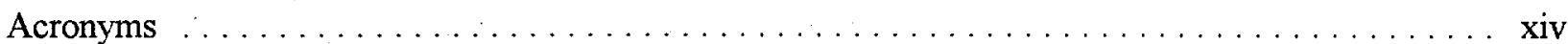

List of Contributors $\ldots \ldots \ldots \ldots \ldots \ldots \ldots \ldots \ldots \ldots \ldots \ldots \ldots \ldots \ldots \ldots \ldots \ldots \ldots \ldots$

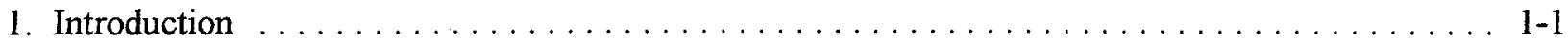

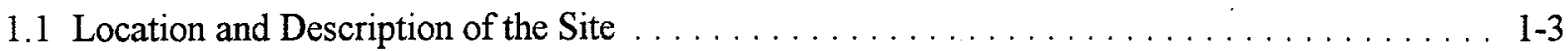

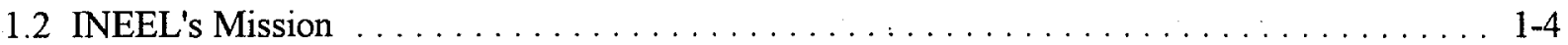

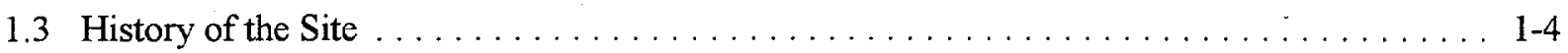

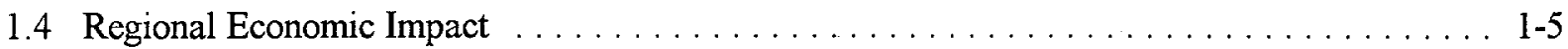

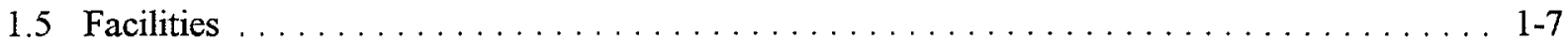

Argonne National Laboratory-West (ANL-W) $\ldots \ldots \ldots \ldots \ldots \ldots \ldots \ldots \ldots \ldots \ldots \ldots \ldots$

Idaho Nuclear Technology and Engineering Center (INTEC) $\ldots \ldots \ldots \ldots \ldots \ldots \ldots \ldots$ 1-7

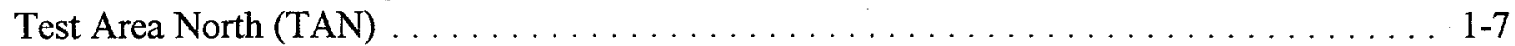

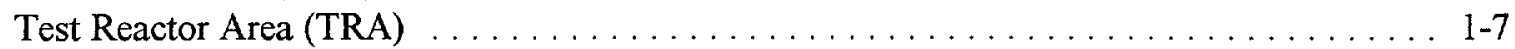

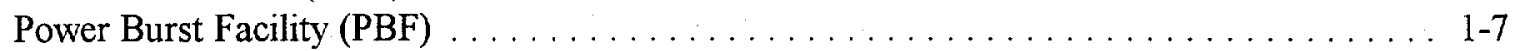

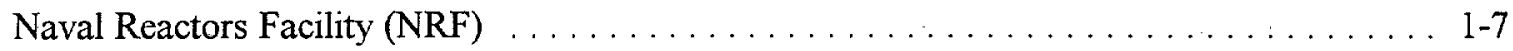

Radioactive Waste Management Complex (RWMC) $\ldots \ldots \ldots \ldots \ldots \ldots \ldots \ldots \ldots \ldots \ldots$

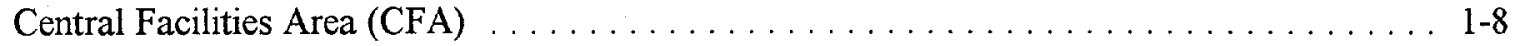

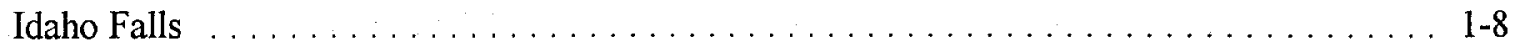

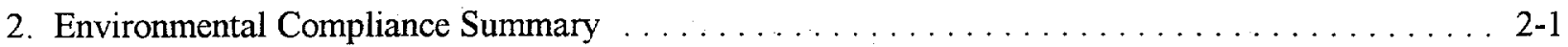

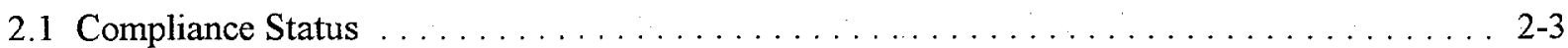

Comprehensive Environmental Response, Compensation and Liability Act (CERCLA) . . . 2-3

Emergency Planning and Community Right-to-Know Act (EPCRA) . . . . . . . . . 2-3

Natural Resource Trusteeship \& Natural Resources Damage Assessment . . . . . . . . . . . 2-4

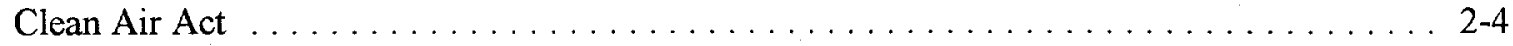

National Emission Standards for Hazardous Air Pollutants $\ldots \ldots \ldots \ldots \ldots \ldots \ldots \ldots . \ldots \ldots$

Clean Water Act . . . . . . . . . . . . . . . . . . . . . . . . . . 2-6

National Pollutant Discharge Elimination System Point Source Discharge Permits . . . . . 2 2-6

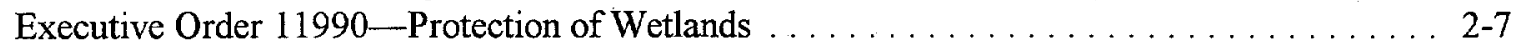

Executive Order 11988 -Floodplain Management $\ldots \ldots \ldots \ldots \ldots \ldots \ldots \ldots \ldots$. . . . . . . . . . 


\section{CONTENTS (Cont.)}

State of Idaho Wastewater Land Application Permits $\ldots \ldots \ldots \ldots \ldots \ldots \ldots \ldots \ldots . \ldots .7$

Resource Conservation and Recovery Act (RCRA) . . . . . . . . . . . . . . . . . . 2-7

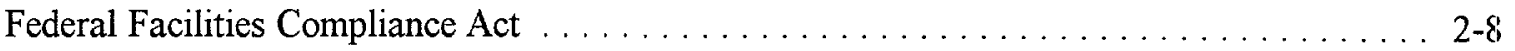

National Environmental Policy Act (NEPA) . . . . . . . . . . . . . . . . . . . . . . 2-9

Safe Drinking Water Act . . . . . . . . . . . . . . . . . . . . . . . . . . . 2-9

Toxic Substances Control Act . . . . . . . . . . . . . . . . . . . . . . . . 2-10

Federal Insecticide, Fungicide, and Rodenticide Act . . . . . . . . . . . . . . . 2-10

National Historic Preservation Act . . . . . . . . . . . . . . . . . . . . . . 2-10

Native American Grave Protection and Repatriation Act $\ldots \ldots \ldots \ldots \ldots \ldots \ldots \ldots$ 2-10

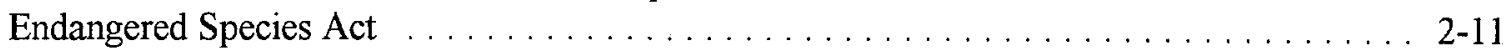

2.2 Other Major Environmental Issues and Activities $\ldots \ldots \ldots \ldots \ldots \ldots \ldots \ldots \ldots \ldots \ldots$

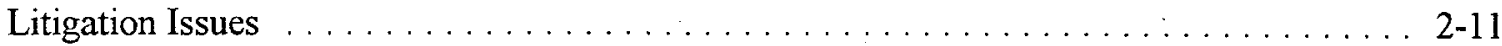

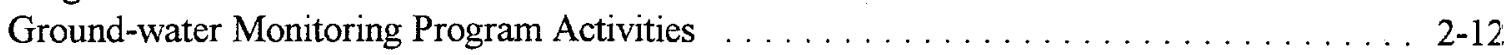

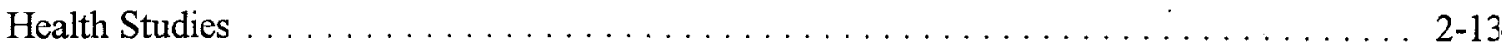

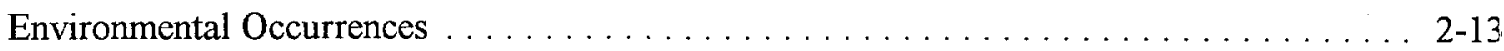

Environmental Oversight and Monitoring Agreement . . . . . . . . . . . . . 2-14

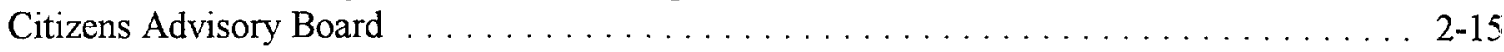

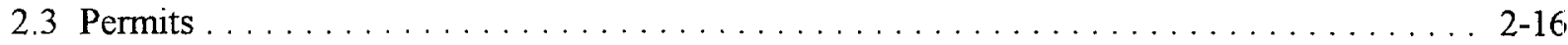

3. Environmental Program Information $\ldots \ldots \ldots \ldots \ldots \ldots \ldots \ldots \ldots \ldots \ldots \ldots \ldots \ldots \ldots \ldots$

3.1 Environmental Management System (EMS) $\ldots \ldots \ldots \ldots \ldots \ldots \ldots \ldots \ldots \ldots \ldots \ldots \ldots$

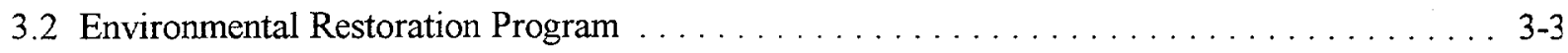

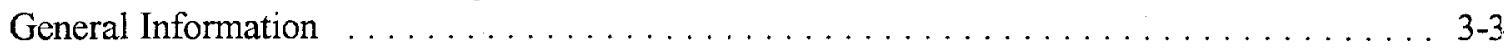

Waste Area Group 1 -Test Area North (TAN) $\ldots \ldots \ldots \ldots \ldots \ldots \ldots \ldots \ldots \ldots .4 . \ldots \ldots$

Waste Area Group 2-Test Reactor Area (TRA) . . . . . . . . . . . . . . . . . . 3-5

Waste Area Group 3-Idaho Nuclear Technology and Engineering Center (INTEC) . . . . . 3-5

Waste Area Group 4-Central Facilities Area (CFA) . . . . . . . . . . . . . . . . . . . 3-5

Waste Area Group 5-Power Burst Facility(PBF)/Auxiliary Reactor Area (ARA) . . . . . . . 3-6

Waste Area Group 6-Boiling Water Reactor Experiment . . . . . . . . . . . . . . . . 3-7

Waste Area Group 7-Radioactive Waste Management Complex (RWMC) . . . . . . . . 3-7

Waste Area Group 8-Naval Reactors Facility (NRF) . . . . . . . . . . . . . . . 3-8

Waste Area Group 9-Argonne National Laboratory-West (ANL-W) . . . . . . . . . . . . . 3-9

Waste Area Group 10-Miscellaneous Sites/Snake River Plain Aquifer . . . . . . . . . . . . . 3-9

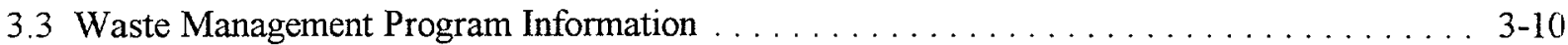

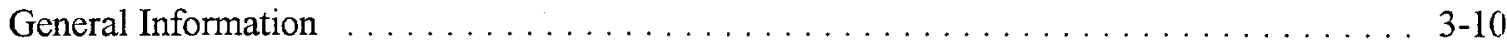

Accomplishments of the Waste Management Program . . . . . . . . . . . . . . . . 3-10

Waste Minimization/Pollution Prevention $\ldots \ldots \ldots \ldots \ldots \ldots \ldots \ldots \ldots \ldots \ldots . \ldots \ldots$. $\ldots \ldots \ldots$

Recycle/Re-use of Excess Materials . . . . . . . . . . . . . . . . . . . 3-13

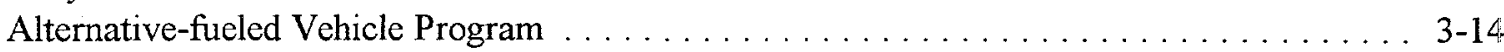

Waste Treatment Accomplishments . . . . . . . . . . . . . . . . . . 3-15 


\section{CONTENTS (Cont.)}

Waste Storage Accomplishments . . . . . . . . . . . . . . . . . . 3-15

Waste Disposal Accomplishments . . . . . . . . . . . . . . . . . . . . 3-16

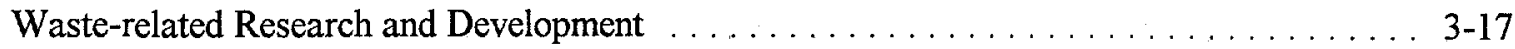

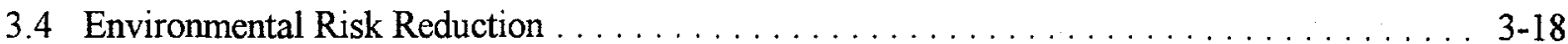

Decontamination \& Dismantlement Activities $\ldots \ldots \ldots \ldots \ldots \ldots \ldots \ldots \ldots \ldots \ldots$. . . . . . . . . . . . . .

Activity Summary . . . . . . . . . . . . . . . . . . . . . . . . . . . 3-19

3.5 Additional Environmental Programs . . . . . . . . . . . . . . . . . . . . . . . 3-19

Public Involvement in INEEL Program Activities . . . . . . . . . . . . . . . . . 3-19

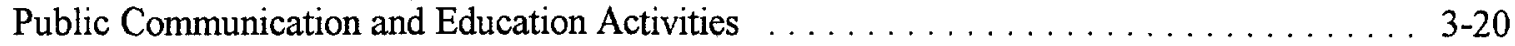

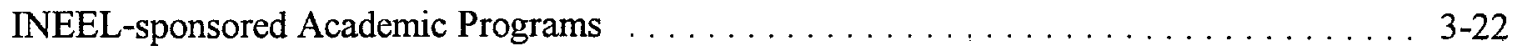

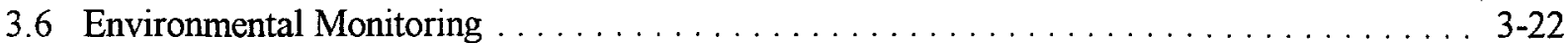

Purpose and Organization of Monitoring Programs $\ldots \ldots \ldots \ldots \ldots \ldots \ldots \ldots \ldots \ldots \ldots \ldots$ 3-22

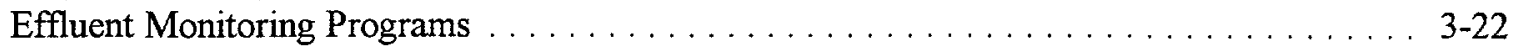

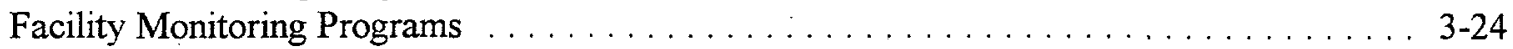

Drinking Water Programs . . . . . . . . . . . . . . . . . . . . . . . . .

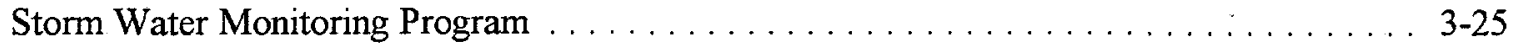

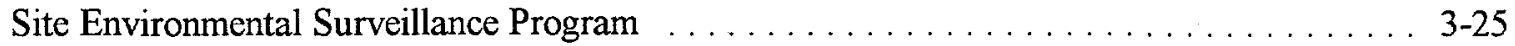

INEEL Offsite Environmental Surveillance Program $\ldots \ldots \ldots \ldots \ldots \ldots \ldots \ldots \ldots \ldots$ 3-28

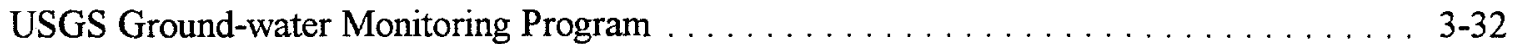

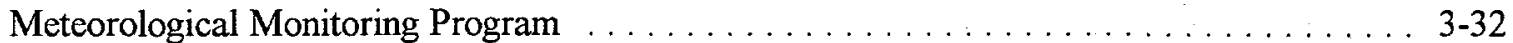

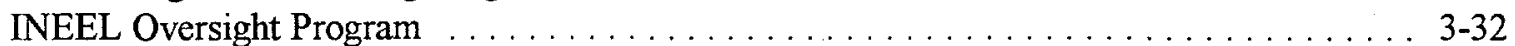

4. Environmental Radiological Program Results $\ldots \ldots \ldots \ldots \ldots \ldots \ldots \ldots \ldots \ldots \ldots \ldots$. . . . . . . .

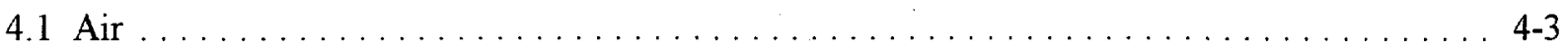

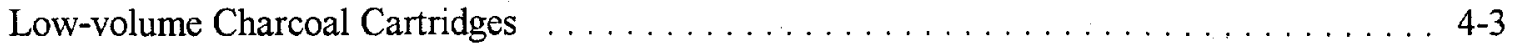

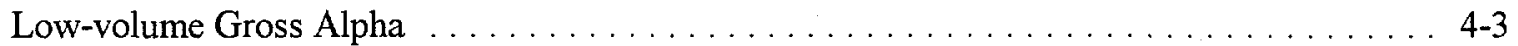

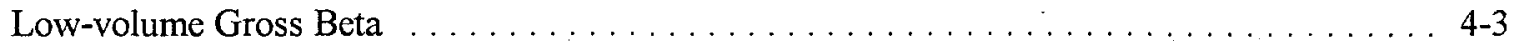

Specific Radionuclides in Air Samples . . . . . . . . . . . . . . . . . . . . . . . . 4-10

Atmospheric Moisture . . . . . . . . . . . . . . . . . . . . . . . . . . . . . . . 4-10

Precipitation $\ldots \ldots \ldots \ldots \ldots \ldots \ldots \ldots \ldots \ldots \ldots \ldots \ldots \ldots \ldots \ldots \ldots \ldots \ldots \ldots \ldots \ldots .12$

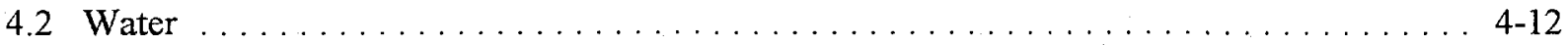

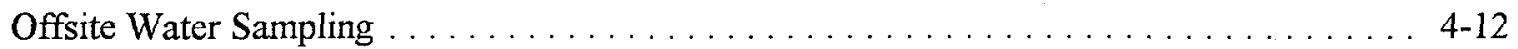

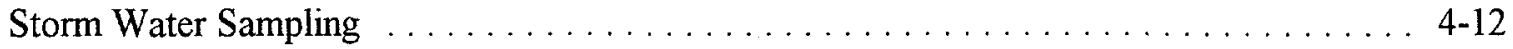

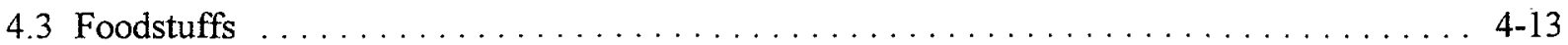

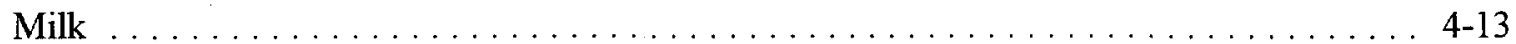

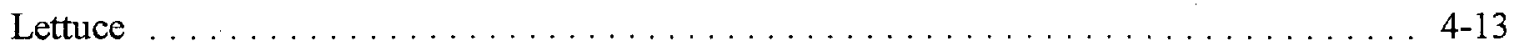

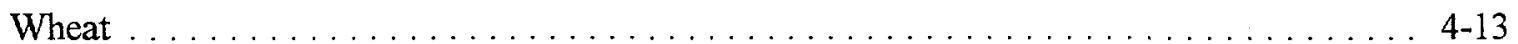

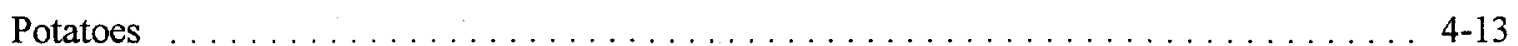

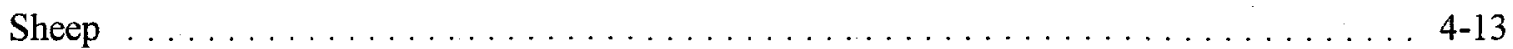

Game Animals . . . . . . . . . . . . . . . . . . . . . . . . . 


\section{CONTENTS (Cont.)}

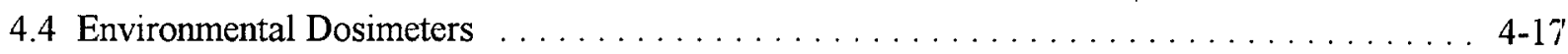

5. Nonradiological Environmental Monitoring Results $\ldots \ldots \ldots \ldots \ldots \ldots \ldots \ldots \ldots \ldots \ldots \ldots$. $5-1$

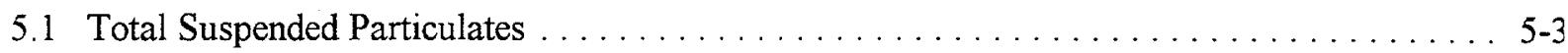

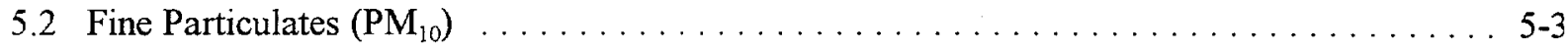

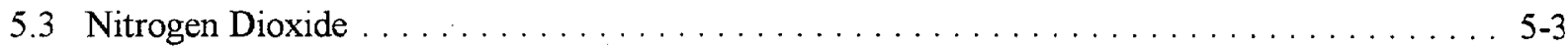

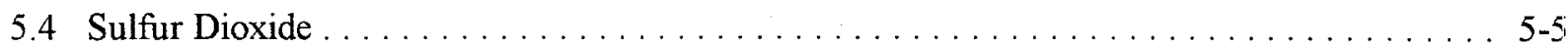

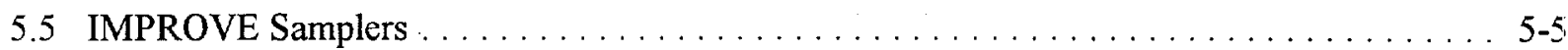

5.6 Storm Water Monitoring $\ldots \ldots \ldots \ldots \ldots \ldots \ldots \ldots \ldots \ldots \ldots \ldots \ldots \ldots \ldots$

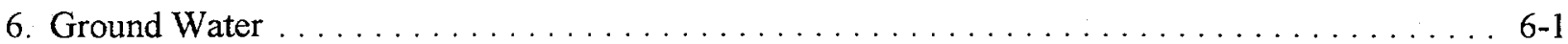

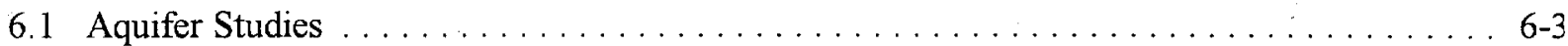

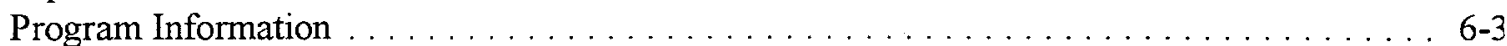

Summary of USGS Special Studies $\ldots \ldots \ldots \ldots \ldots \ldots \ldots \ldots \ldots \ldots \ldots \ldots \ldots \ldots$

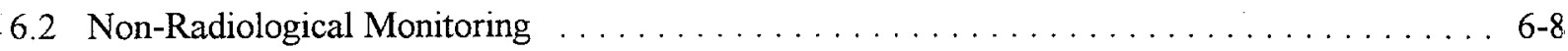

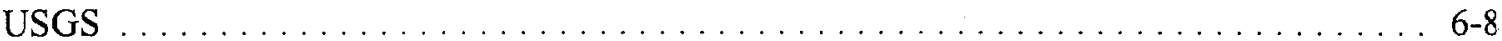

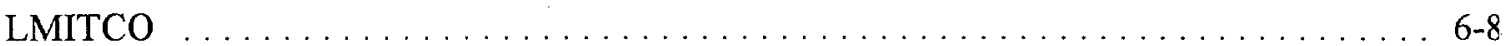

Argonne National Laboratory-West (ANL-W) . . . . . . . . . . . . . . . . . . 6-9

Naval Reactors Facility (NRF) . . . . . . . . . . . . . . . . . . . . . . . . . . . 6-9

6.3 Radiochemical Monitoring . . . . . . . . . . . . . . . . . . . . . . . . . . . 6-11

USGS ..................................... $6-11$

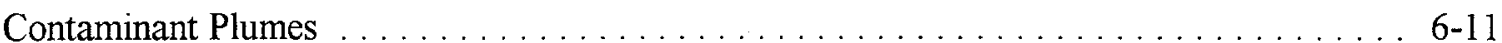

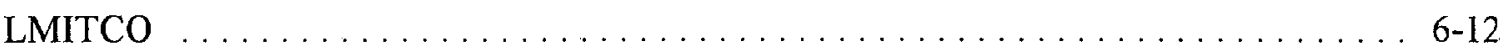

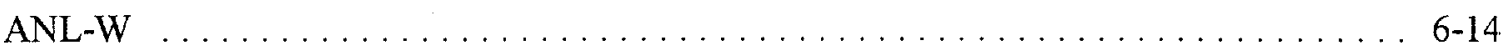

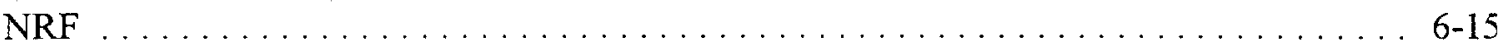

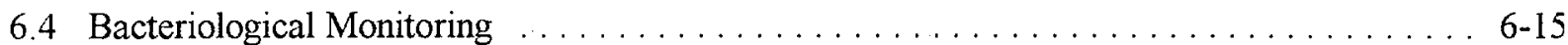

LMITCO . . . . . . . . . . . . . . . . . . . . . . . . . . . . . 6 6-15

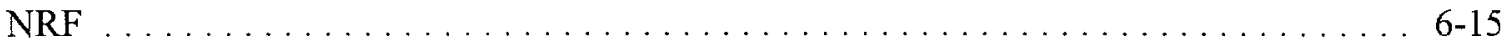

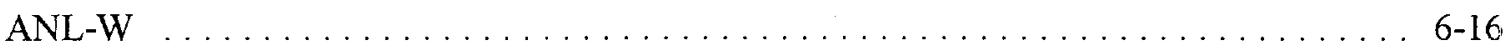

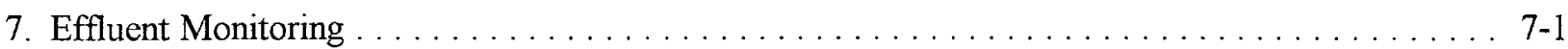

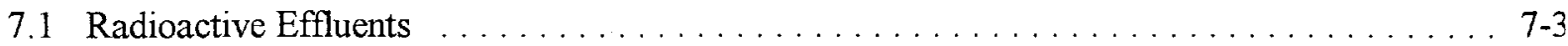

General .................................... $7-3$

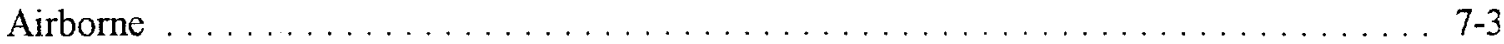

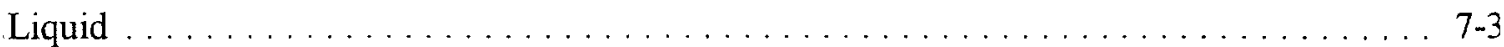

xix 


\section{CONTENTS (Cont.)}

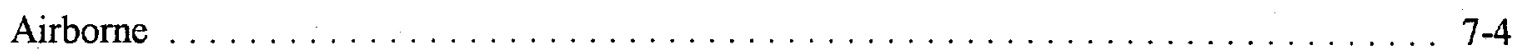

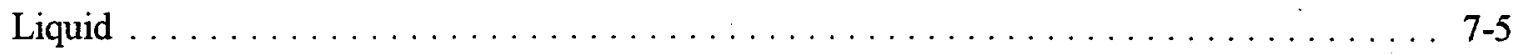

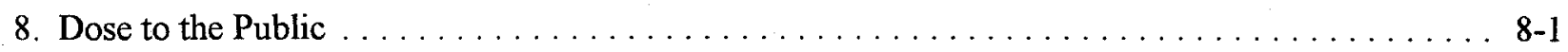

8.1 General Information $\ldots \ldots \ldots \ldots \ldots \ldots \ldots \ldots \ldots \ldots \ldots \ldots \ldots \ldots \ldots$

8.2 Maximum Individual Dose-Airborne Emissions Pathway $\ldots \ldots \ldots \ldots \ldots \ldots \ldots \ldots$

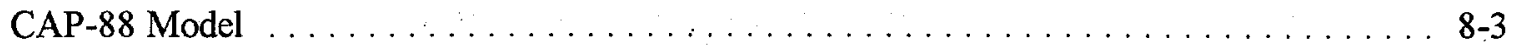

MDIFF Model . . . . . . . . . . . .

8.3 Maximum Individual Dose-Game Ingestion Pathway $\ldots \ldots \ldots \ldots \ldots \ldots \ldots$

8.480 -kilometer Population Dose $\ldots \ldots \ldots \ldots \ldots \ldots \ldots \ldots \ldots \ldots \ldots \ldots \ldots$

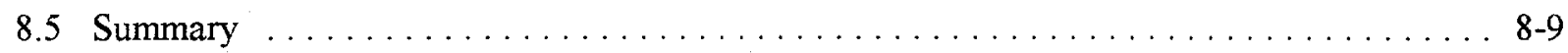

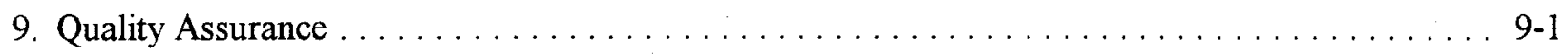

9.1 Quality Assurance Programs $\ldots \ldots \ldots \ldots \ldots \ldots \ldots \ldots \ldots \ldots \ldots \ldots \ldots \ldots$

9.2 Laboratory Intercomparison Programs . . . . . . . . . . . . . . . . . . . $9-3$

General Information . . . . . . . . . . . . . . . . . . . . . . . .

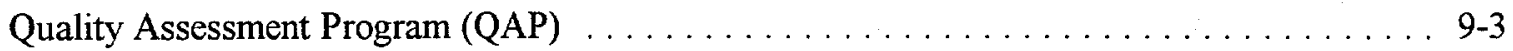

National Institute of Standards and Technology (NIST) $\ldots \ldots \ldots \ldots \ldots \ldots \ldots \ldots . . \ldots$

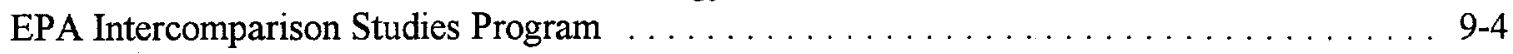

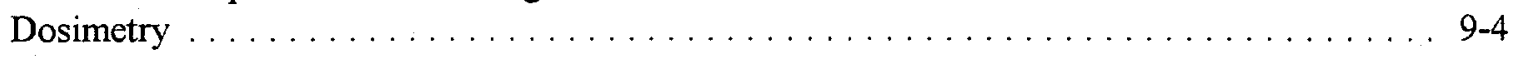

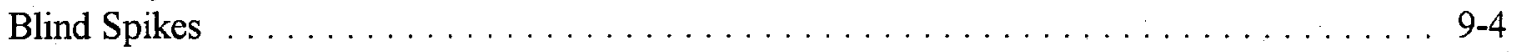

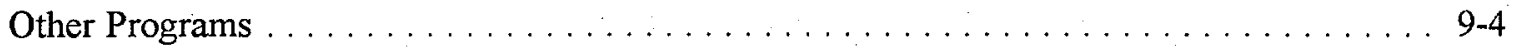

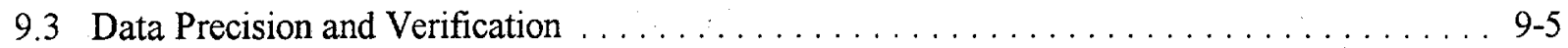

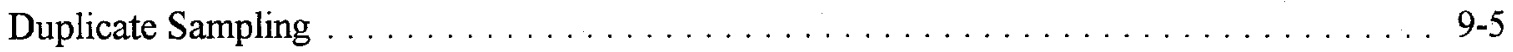

Duplicate Data Comparisons . . . . . . . . . . . . . . . . . . . . .

Appendix A-Environmental Standards and Regulations $\ldots \ldots \ldots \ldots \ldots \ldots \ldots \ldots \ldots \ldots \ldots$

Appendix B-Statistical Methods Used for the Environmental Surveillance Program . . . . . . . . B-1

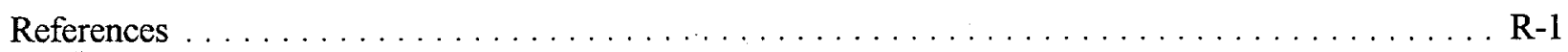




\section{FIGURES}

1-1 Location of INEEL $\ldots \ldots \ldots \ldots \ldots \ldots \ldots \ldots \ldots \ldots \ldots \ldots \ldots \ldots \ldots \ldots$

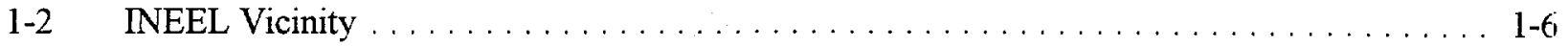

1-3 INEEL Facilities $\ldots \ldots \ldots \ldots \ldots \ldots \ldots \ldots \ldots \ldots \ldots \ldots \ldots \ldots \ldots \ldots \ldots$

3-1 Potential Pathways from the INEEL to Humans $\ldots \ldots \ldots \ldots \ldots \ldots \ldots \ldots \ldots \ldots$

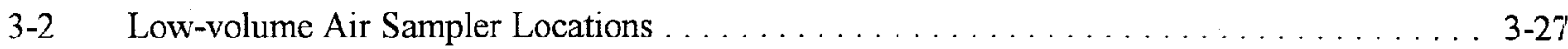

3-3 Offsite Foodstuff Sampling and Environmental Dosimeter Locations . . . . . . . . . . . . 3-31

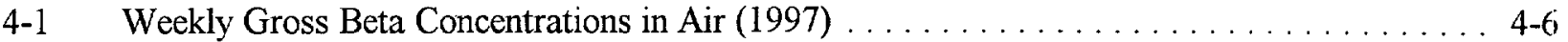

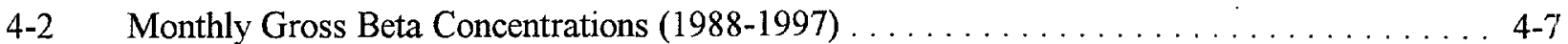

4-3 Environmental Dosimeter Measurements at ANL-W (1997) . . . . . . . . . . . . . . . . . . 4-21

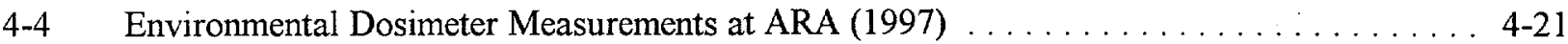

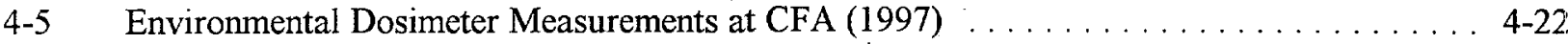

4-6 Environmental Dosimeter Measurements at INTEC (1997) . . . . . . . . . . . . . . 4-22

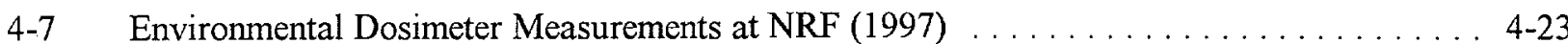

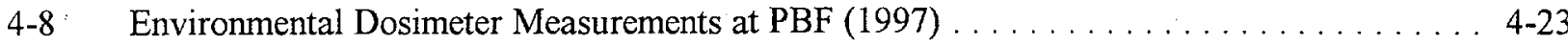

4-9 Environmental Dosimeter Measurements at RWMC (1997) . . . . . . . . . . . . . . 4-24

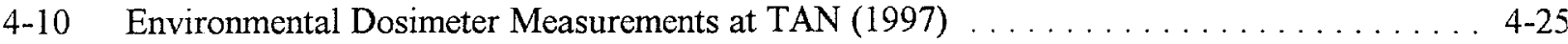

4-11 Environmental Dosimeter Measurements at TRA (1997) . . . . . . . . . . . . . . . . 4-25

4-12 Environmental Dosimeter Measurements along Lincoln Blvd. and U.S. Highways $20 \& 26(1997) \ldots \ldots \ldots \ldots \ldots \ldots \ldots \ldots \ldots . \ldots \ldots$. . . . . . . . . . . .

$5-1 \quad$ Nitrogen/Sulfur Dioxide Monitoring Locations $\ldots \ldots \ldots \ldots \ldots \ldots \ldots \ldots \ldots$

5-2 Nitrogen Dioxide and Sulfur Dioxide Concentrations at the INEEL (1990-1997) . . . . . 5-6

5-3 Fine Mass $\left(\mathrm{PM}_{2.5}\right)$ Concentrations at Craters of the Moon and CFA (1992-1997) . . . . . . 5-8 


\section{FIGURES (Cont.)}

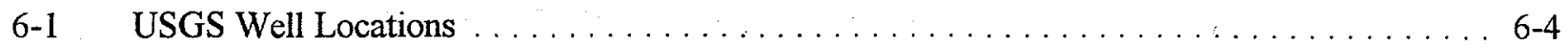

6-2 USGS Well Locations at INTEC-TRA and RWMC $\ldots \ldots \ldots \ldots \ldots \ldots \ldots \ldots \ldots$

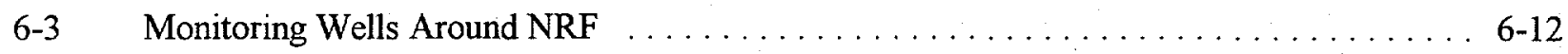

6-4 Distribution of Tritium in the Snake River Plain Aquifer on the INEEL, $1995 \ldots \ldots$. . . 6-13

6-5 . Distribution of ${ }^{90} \mathrm{Sr}$ in the Snake River Plain Aquifer on the INEEL, $1995 \ldots \ldots \ldots \ldots$

6-6 Tritium Concentrations in INEEL Production Wells and

Distribution Systems $(1987-1997) \ldots \ldots \ldots \ldots \ldots \ldots \ldots$ 6-16

$7-1 \quad$ INEEL Airborne Radioactive Effluent $\ldots \ldots \ldots \ldots \ldots \ldots \ldots \ldots \ldots \ldots \ldots \ldots \ldots$

8-1 Average Mesoscale Dispersion Isopleths of Air Concentrations at Ground Level, Normalized to Unit Release Rate of TRA/INTEC $\ldots \ldots \ldots \ldots \ldots \ldots \ldots \ldots \ldots \ldots$. $\ldots$.5

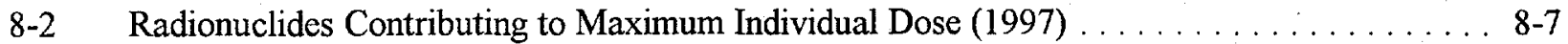




\section{TABLES}

2-1 INEEL 1997 Emergency Planning and Community Right-to-Know Act Update $\ldots \ldots \ldots$. . 2-4

2-2 Permit Summary for the INEEL $(1997) \ldots \ldots \ldots \ldots \ldots \ldots \ldots \ldots \ldots \ldots \ldots \ldots \ldots$

3-1 LMITCO Environmental Surveillance Radiological Program Summary (1997) . . . . . . . . 3-26

3-2 Environmental Science and Research Foundation Environmental Surveillance Radiological Monitoring Program Summary (1997) . . . . . . . . . . . . . . . . 3-29

3-3 USGS Ground-water Monitoring Program Summary $\ldots \ldots \ldots \ldots \ldots \ldots \ldots \ldots \ldots$

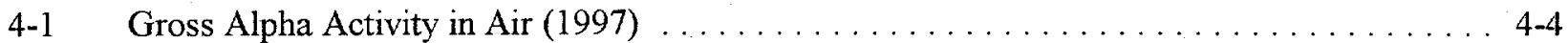

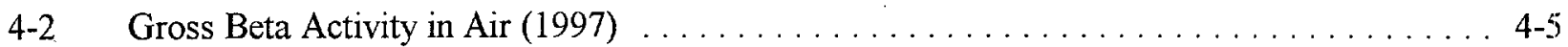

4-3 Statistical Comparison Table of Gross Beta Concentrations in Air at Distant,

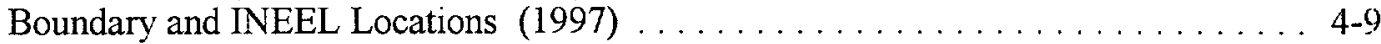

4-4 Manmade Radionuclides in Foundation Air Samples (1997) . . . . . . . . . . . . . . 4-1 $\mathbb{1}$

4-5 Strontium-90 Concentrations in Garden Lettuce $(1993-1997) \ldots \ldots \ldots \ldots \ldots \ldots \ldots$. . . . . . . . 4-13

4-6 Strontium-90 Concentrations in Wheat $(1993-1997) \ldots \ldots \ldots \ldots \ldots \ldots \ldots \ldots$. . . . . . . . . . . .

4-7 Manmade Gamma-emitting Radionuclides in Edible Portions of Waterfowl (1997) . . . . . 4-15

4-8 Strontium-90 and Transuranics in Edible Portions of Waterfowl (1997) . . . . . . . . 4-16

4-9 Manmade Radionuclides in Breast Meat of Mourning Doves (1997) . . . . . . . . . . . 4 4-17

4-10 Environmental Radiation Exposures $(1993-1997) \ldots \ldots \ldots \ldots \ldots \ldots \ldots \ldots$. . . . . . . . . .

4-11 Estimated Natural Background Effective Dose Equivalent (1997) . . . . . . . . . . . . . 4-19

5-1 Particulate Matter Concentrations in Air $(1997) \ldots \ldots \ldots \ldots \ldots \ldots \ldots \ldots \ldots \ldots$

5-2 Ten-year Summary of Particulate Matter Concentrations $(1987-1997) \ldots \ldots \ldots \ldots \ldots$

5-3 Data for IMPROVE Samplers at CFA and Craters of the Moon National Monument (May1992-February 1997) ... . . . . . . . . . . . . . . . . . 5-7

5-4 Nonradiological Storm Water Monitoring Data $(1997) \ldots \ldots \ldots \ldots \ldots \ldots \ldots \ldots$ 


\section{TABLES (Cont.)}

6-1 Purgeable Organic Compounds in USGS Well Samples (1997) . . . . . . . . . . . . . . 6-9

6-2 Purgeable Organic Compounds $[\mu \mathrm{g} / \mathrm{L}]$ in INEEL Drinking Water $(1997) \ldots \ldots \ldots \ldots$. . . . . .

6-3 Inorganic Chemicals in INEEL Potable and Production Wells (1997) . . . . . . . . . . 6-11

6-4 Tritium Concentrations in INEEL Production Wells and Distribution Systems (1997) . . . 6-14

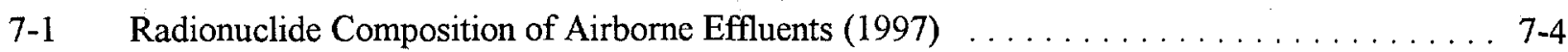

7-2 Radionuclide Composition of Liquid Effluent Released Onsite (1997) . . . . . . . . . . 7-5

7-3 Summary of $\mathrm{NO}_{2}$ and $\mathrm{SO}_{2}$ Emissions and Ambient Monitoring

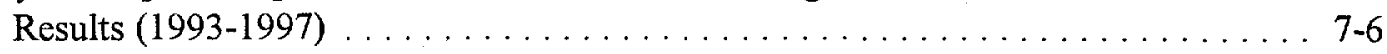

7-4 TRA Liquid Effluent Inorganic Monitoring Data $(1997) \ldots \ldots \ldots \ldots \ldots \ldots \ldots$

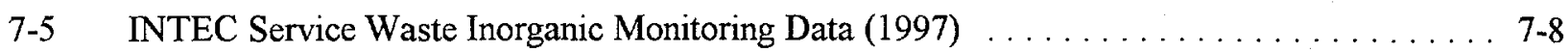

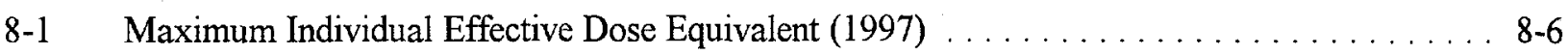

8-2 Dose from Ingestion of Muscle Tissue of Waterfowl Using

INEEL Waste Disposal Ponds (1997) . . . . . . . . . . . . . . 8-8

8-3 Dose from Ingestion of Mourning Doves Using INEEL Waste

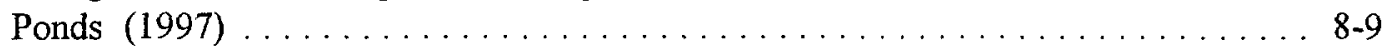

8-4 80-Kilometer Population Dose $(1997) \ldots \ldots \ldots \ldots \ldots \ldots \ldots \ldots \ldots \ldots \ldots$

8-5 Summary of Annual Effective Dose Equivalents Due to INEEL Operations (1997) _ . . 8-11

9-1 Environmental Measurements Laboratory (EML) Quality Assessment Program Results for the Environmental Assessment Laboratory (EAL) [1997] . . . . . . . . . . . . 9-4

9-2 Environmental Measurements Laboratory (EML) Quality Assessment Program Results

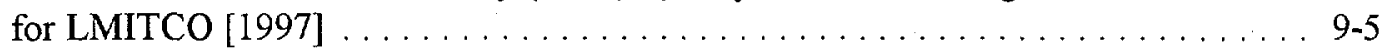

9-3 Environmental Measurements Laboratory (EML) Quality Assessment Program Results for Paragon Analytics, Inc. [1997] . . . . . . . . . . . . . . . . 9-6

9-4 Environmental Measurements Laboratory (EML) Quality Assessment Program Results

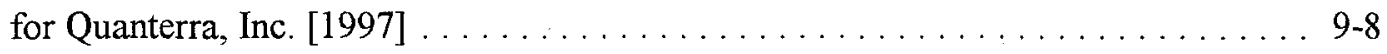

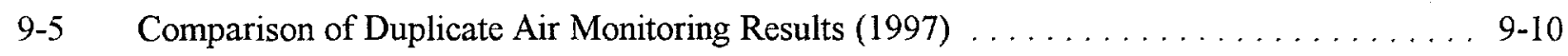

9-6 Comparison of Foundation, LMITCO and State of Idaho Air Monitoring Results

(1997)-Gross Alpha 
TABLES (Cont.)

9-7 Comparison of Foundation, LMITCO and State of Idaho Air Monitoring Results (1997)-Gross Beta . . . . . . . . . . . . . . . . . . . . . .

9-8 Comparison of Foundation and State of Idaho Water Monitoring Results (1997) . . . . 9-13

A-1 Derived Concentration Guides for Radiation Protection $\ldots \ldots \ldots \ldots \ldots \ldots \ldots \ldots \ldots$ A-2

A-2 Radiation Standards for Protection of the Public in the Vicinity of DOE Facilities . . . . . A A-3

A-3 EPA Ambient Air Quality Standards $\ldots \ldots \ldots \ldots \ldots \ldots \ldots \ldots \ldots \ldots \ldots \ldots \ldots \ldots \ldots$

A-4 EPA Maximum Contaminant Levels for Nontransient Noncommunity Drinking Water Systems . . . . . . . . . . . . . . . . . . . . A 4 . 


\section{LIST OF CONTRIBUTORS}

Brad Andersen

W.G. Bass

Roy Bartholomay

Bob Bates

Mike Bennett

Bryan Borsella

Teresa Brock

Ron Brooks

Eddie Chew

Roy Evans

Lori Fritz

John Gill

Katie Hain

Rosemary Haines

Carol Hathaway

Neil Hukari

Talley Jenkins

Nolan Jensen

Alan Jines

Patti Kroupa

B. Sue Lantz

Chuck Ljungberg

Stacey Madsen

Christopher Martin

Don Martin

Teresa Meachum
John Medema

Maria Miles

Patty Natoni

Joan Neff

R.D.E. Newbry

Kevin O'Neill

Brennon Orr

Don Rasch

Tim Reynolds

Donny Roush

Woody Russell

Jerry Sagendorf

Mark Shaw

Chris Staley

Leah Street

Karen Taylor

Jim Tkachyk

Betty Tucker

Roger Twitchell

Dennis Walker

Ron Warren

Dave Wessman

Roger Wilhelmsen

Mary Willcox

Stephanie Woolf 


\section{Summary of Chapter 1 \\ Introduction}

The Idaho National Engineering and Environmental Laboratory (INEEL), a 2,300-km² U.S. Department of Energy site on the Snake River Plain of Idaho, employs 8,100 people. They work on nationally important nuclear energy, systems engineering, and environmental technology problems. The INEEL was founded in 1949 and occupies a mostly undeveloped site of sagebrush desert. This chapter describes the INEEL's environment (Section 1.1), mission (Section 1.2), history (Section 1.3), economic impact (Section 1.4), and facilities (Section 1.5). 



\section{INTRODUCTION}

\subsection{LOCATION AND DESCRIPTION OF THE SITE}

In Idaho, the U.S. Department of Energy (DOE) owns and administers the Idaho National Engineering and Environmental Laboratory (INEEL). Located in the southeastern portion of the state, the INEEL occupies approximately 2,300 $\mathrm{km}^{2}$ (890 square miles) on the upper Snake River Plain and represents an important example of the sagebrush-steppe biome [Reference 1-1]. The INEEL site extends $63 \mathrm{~km}$ (39 miles) from north to south and is about $58 \mathrm{~km}$ ( 36 miles) across at its broadest east-west extent (Figure 1-1). Average elevation across the INEEL is approximately 1,500 $\mathrm{m}(4,900 \mathrm{ft})$ above sea level. The Site is bordered on the north and west by three basin-and-range fault block mountain ranges and on the south by three buttes of volcanic origin. Lands immediately beyond the boundaries of the INEEL are desert, foothills, or agricultural fields. Most of the nearby farming is concentrated northeast of the INEEL. Large areas of agricultural land are farmed adjacent to the Snake River, but these regions are more distant from the INEEL.

The altitude, intermountain setting, and latitude of the INEEL combine to produce a semi-arid climate [Reference 1-2]. Prevailing weather patterns are from the southwest, moving up the Snake River Plain. Air masses, which gather moisture over the Pacific Ocean, traverse several hundred miles of mountainous land prior to reaching southeastern Idaho. The result is frequently dry air and little cloud cover. Solar heating can be intense with extreme day-to-night temperature fluctuations.

The climate of the cold desert environment of the INEEL is characterized by sparse precipitation, hot summers, and cold winters. The Site's climate and mostly alkaline soils support plant communities and animal populations able to cope with both dryness and temperature extremes. Most of the plain is covered by basalt flows, which produce a

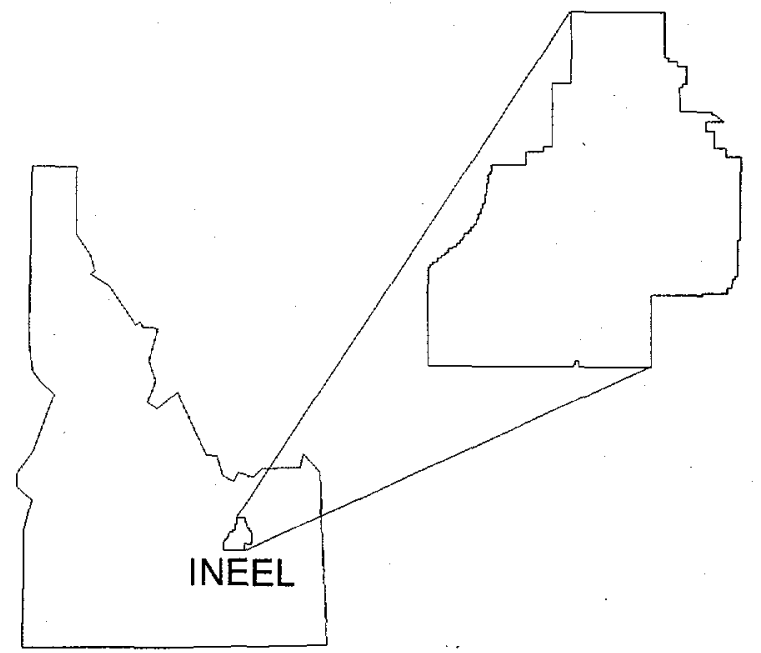

Figure 1-1. Location of INEEL

rolling topography. Vegetation is visually dominated by big sagebrush. Beneath these shrubs is found an array of grasses and flowering plants, most adapted to the harsh climate. A recent plant inventory counted 409 species on the INEEL [Reference 1-3]. Vertebrate animals are represented by suites of small burrowing mammals, snakes, birds of prey, and several game species. Published species counts include six fishes, two amphibians, 11 reptiles, 224 birds and 44 mammals [Reference 1-4]. Sixty percent of the INEEL is open to livestock grazing.

Within the plain, and its ample basalt flows interceded with sedimentary deposits, is a productive aquifer. The eastern Snake River Plain Aquifer stores one of the most bountiful supplies of ground water in the nation. An estimated 200 to 300 million acre-feet are stored in the aquifer's upper portions. Significant recharge of the aquifer beneath the INEEL comes from waters of the Henry's Fork of the Snake River, as well as the South Fork of the Snake River, Big Lost River, Little Lost River, and Birch Creek drainages. In this century, irrigation recharge has come to account for as much as $60 \%$ of the water returning to the aquifer. The Big Lost River and Birch 
Creek flow onto the INEEL during wet periods. There, they sink into porous soils. Beneath the INEEL, the aquifer moves laterally to the southwest at a rate of $1.5 \mathrm{~m}$ to $6 \mathrm{~m} /$ day ( 5 to $20 \mathrm{ft} /$ day) The eastern Snake River Plain Aquifer emerges in springs along the Snake River between Milner and Bliss, Idaho. On the Snake River Plain, the preponderant use of both surface water and ground water is for crop irrigation.

The INEEL consists of several primary facility areas located on an expanse of otherwise undeveloped terrain. Most buildings and structures on the INEEL are situated within facilities, leaving about $94 \%$ of the Site undeveloped and open land [Reference 1-5]. Such an expanse of sagebrush steppe offers important ecological characteristics, with representative suites of native animals and plants functioning without major human disturbances from agriculture and recreation.

\subsection{INEEL'S MISSION}

The DOE Idaho Operations Office (DOE-ID) has stated its mission in this way: "Through world class applied engineering, we will clean up the cold war legacy, execute multi-program missions, and leverage INEEL's expertise with merging technology to meet the Nation's needs." The INEEL is dedicated to restoring and protecting our environment and now reflects that emphasis by adding the words "and Environmental" to the Laboratory's name to more closely represent the site's missions.

In addition to this stated mission, DOE-ID is committed to providing a safe and healthy workplace for its employees, protect public health and safety, and protect the environment. The INEEL was designated the second of seven National Environmental Research Parks (NERP) in 1975.

NERPs are used to assist in scientific endeavors to evaluate the environmental consequences of energy use and development as well as the strategies to mitigate such effects [Reference 1-6].

About $60 \%$ of the INEEL's funding is devoted to environmental restoration and waste manage- ment activities. The INEEL's environmental program is laid out over the next 40 years through the Idaho Settlement Agreement for spent nuclear fuel and radioactive waste, the Site Treatment Plan for Mixed Wastes and the cleanup agreement among the DOE, the state of Idaho, and the Environmental Protection Agency. These legally enforceable agreements are geared toward assessing and remediating past contamination of the Site, and putting wastes now stored at the Site in more stable forms "road ready" for disposal when per-manent repositories become available.

The other $40 \%$ of the INEEL budget funds ongoing programs like the Advanced Test Reactor, and research into a wide range of fields, including energy efficiency, renewable energy, technology development, systems engineering and other areas. "Finish the 60 , grow the 40 " is shorthand for INEEL's two strategic priorities.

\subsection{HISTORY OF THE SITE}

The geologic events that have shaped the modern Snake River Plain on and near the INEEL took place during the last two million years [References 1-7 \& 1-8]. The plain, which arcs across eastern Oregon and southern Idaho, marks the passage of the earth's crust over a dome of mantle material pressing up from the super-heated center of the planet. The resultant lava flows are oldest in the west and youngest at the Yellowstone Pla-. teau, where the thermal upwelling is most evident today. The plain is a $650 \mathrm{~km}$ (400 mile) trail made by the passage of the continent over the "hot spot."

Human use of the upper Snake River Plain, and especially of the lands of the INEEL, seems to have always been sporadic and nomadic since humans appeared in the area 10,000 to 12,000 years ago. The Shoshone and Bannock peoples lived in socially fluid groups travelling among the mountains, plains, and river bottoms as their seasonal needs changed. From the plain, game animals were taken in late summer. Obsidian and other useful stones were quarried at Big Southern 
Butte. Plants, from camas to dogbane, were gathered. A prime route between the Fort Hall area and the Camas Prairie passed across the plain near the three buttes, and across what became the INEEL.

The earliest exploratory visits by European descendants came in the $1810 \mathrm{~s}, 20 \mathrm{~s}$, and ' $30 \mathrm{~s}$. Trappers scrounged over the plain seeking new supplies of beavers for pelts. Their impressions discouraged potential settlers, and the pioneers using the Oregon Trail avoided lingering in the high desert. The second half of the 1800 s saw valuable ores mined in the surrounding mountains and the beginning of cattle and sheep grazing in the valleys. More lines of transportation-stock trails and stage routes-pressed across the plain. A railroad opened between Blackfoot and Arco in 1901. There was by then sufficient enticement for homesteaders to attempt to win a section of land on the plain. The Carey Land Act of 1894 and the Desert Reclamation Act of 1902 are credited as setting the stage for Idaho's irrigation-based farming economy. The heart of the plain remained immune to irrigation attempts, however. The porosity of its soils could not be overcome and water drained out of the bottom of newly-built canals faster than it could be carried to crops and stock. A broad swath of the eastern plain is still sparsely inhabited.

World War II brought Pocatello a plant where large guns from the U.S. Navy ships were retooled. The U.S. Naval Ordnance Station was one of two such installations. This factory was located inland for fear of being too enticing of a target for enemy bombs along a coast. Retooled guns must be tested, and the nearby, uninhabited plain was put to use as a gunnery range. In the aftermath of the war, as the nation moved to learn how to tame the newly-released powers within atoms, the Naval Proving Ground caught the eye of the Atomic Energy Commission (AEC). On the AEC's drawing boards were plans for an isolated facility with ample water supply at which to build, test, and perfect nuclear reactors. The plain was chosen as the best location.
Arco's proving ground became the National Reactor Testing Station (NRTS) in 1949, under the Atomic Energy Commission, predecessor to the DOE. The station's administrative offices were situated in Idaho Falls, then a city of less than 20,000. By the end of 1951, a reactor at the NRTS produced useful electricity. The facility evolved into an assembly of 52 reactors, associated research centers, and waste handling areas. Only three reactors are operable today. The NRTS had a technological mission that required both of the defining characteristics of the Snake River Plain, desert land and ample ground water. The NRTS was renamed the Idaho National Engineering Laboratory in 1974 and Idaho National Engineering and Environmental Laboratory in January 1997 [Reference 1-9].

The human population, based on 1990 census figures, living within $80 \mathrm{~km}$ ( 50 miles) of the INEEL's operational center is 121,500 [Reference 1-10]. There are no permanent residents within $16 \mathrm{~km}$ (10 miles) of that center (Figure 12). Atomic City (population 25) is the closest community to the INEEL's center. Other boundary communities include Arco (population 1,106), Howe (population 20), Monteview (population 10), Mud Lake (population 179), and Terreton (population 100). The larger population centers of Idaho Falls (population 49,928), Blackfoot (population 10,769), and Pocatello (population $50,588)$ are at least $35 \mathrm{~km}$ (22 miles) from the nearest INEEL boundary.

\subsection{REGIONAL ECONOMIC IMPACT}

Approximately 8,100 people work at the INEEL, making it the largest employer in eastern Idaho. This number includes about 400 federal employees, most of whom work for DOE's Idaho Operations Office. The majority of the other 7,700 work for Lockheed Martin Idaho Technologies Company (LMITCO). Others work for contractors such as Westinghouse Electric Corporation, the University of Chicago's Argonne National Laboratory and various contractors and subcontractors. 


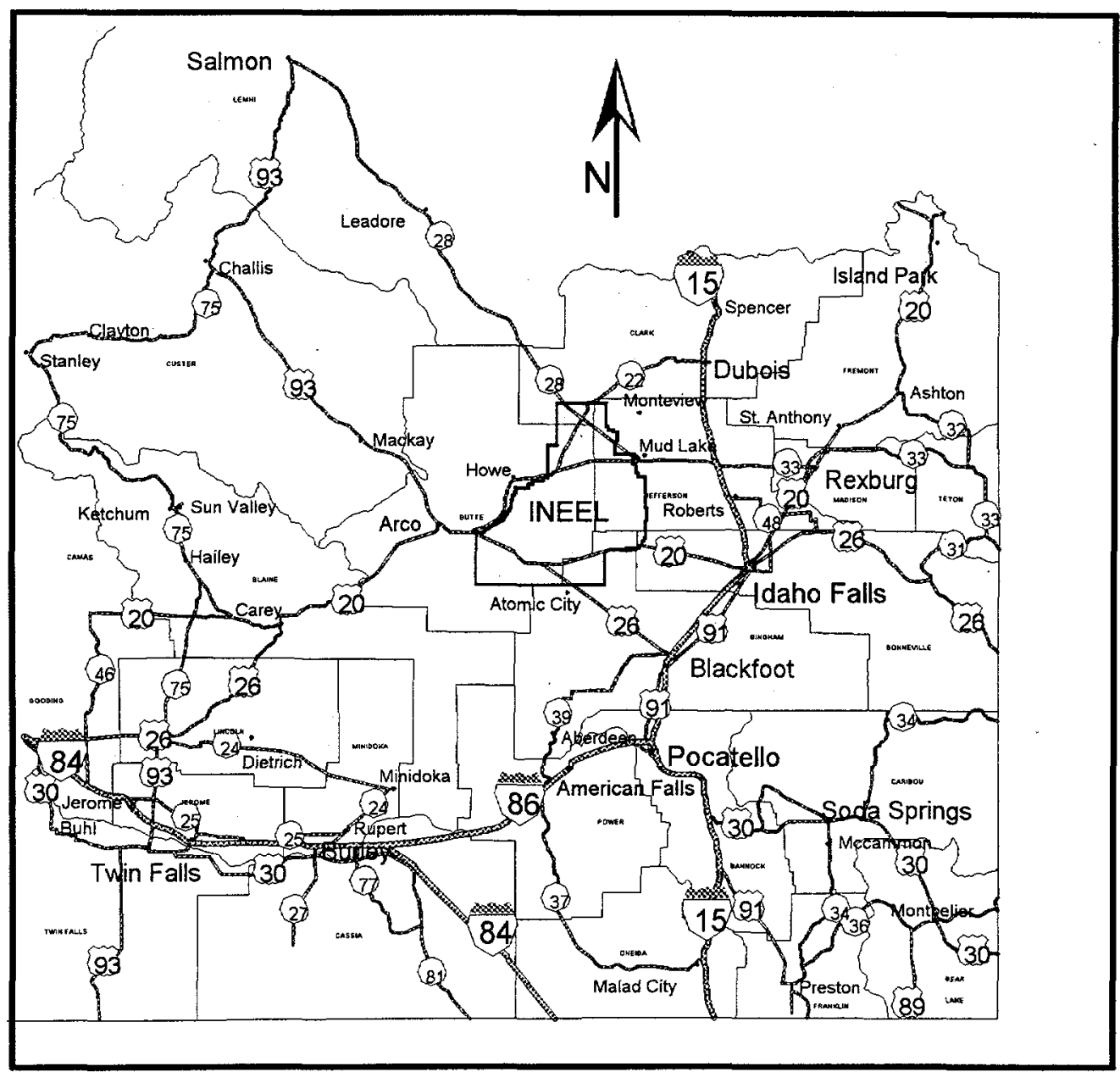

Figure 1-2. INEEL Vicinity

With a fiscal year 1997 budget of $\$ 827$ million, the INEEL has a tremendous economic impact. The following statistics demonstrate why the INEEL is an integral component of Idaho's economy and society [Reference 1-9].

- The INEEL generated 15,114 jobs and accounted for more than half a billion dollars in economic activity for Idaho.

- The INEEL made direct payments of $\$ 380$ million to its employees in salaries and wages which generated an additional $\$ 112$ million in indirect earnings.

- The INEEL purchased $\$ 135$ million worth of goods and services from Idaho businesses. Nearly $90 \%$ was purchased from businesses in southeastern Idaho.

- Nearly 4,000 people visited the INEEL and spent $\$ 590,000$ on food and lodging in the local economy.

- The average INEEL employee earned $\$ 47,000$. The average INEEL family earned 
$\$ 67,000$ and paid an average of $\$ 17,000$ in taxes. Altogether INEEL families paid $\$ 117$ million in taxes.

- DOE and INEEL contractors consistently give their time and income to the community through various civic activities. In 1997 , $1,223,888$ hours were contributed to community concerns, church affiliations, educational activities, political and issue-related causes, youth and other areas of interest.

\subsection{FACILITIES}

The Idaho National Engineering and Environmental Laboratory is operated for the U.S. Department of Energy by LMITCO. Additional facilities are operated by Westinghouse Electric Corporation and the University of Chicago's Argonne National Laboratory. Facilities are located in the city of Idaho Falls and at eight operating areas on the INEEL (Figure 1-3). Major facilities, and their current missions, are listed in the following sections.

\section{Argonne National Laboratory-West (ANL-W)}

This facility is operated by the University of Chicago's Argonne National Laboratory under contract to the DOE-Chicago Operations Office. The present mission of the laboratory is research into spent nuclear fuel, nuclear proliferation, and waste reduction and cleanup technologies.

\section{Idaho Nuclear Engineering and Technology Center (INTEC)}

The Idaho Nuclear Engineering and Technology Center (INTEC, formerly Idaho Chemical Processing Plant or (ICPP)) receives and stores nuclear fuels from the U.S. Navy and other activities. Technologies for treatment and disposal of high-level waste are being developed at the plant. High-level wastes are being treated and will ulti-: mately be prepared for disposal in a permanent repository.

\section{Test Area North (TAN)}

Located at the north end of the INEEL, TAN was built to house the program to develop a nuclear-powered airplane during the 1950s. Facilities include one of the world's largest "hot shops," which also supported research into the Three Mile Island accident from 1986 to 1990 . The largest program currently at TAN, the Specific Manufacturing Capability Project, produces armor for the M1A2 Abrams tank for the U.S. Army.

\section{Test Reactor Area (TRA)}

The TRA has studied the effects of radiation on materials, fuels, and equipment for over 40 years. The Advanced Test Reactor at TRA is currently used for the production of important isotopes used in medicine, research and industry.

\section{Power Burst Facility (PBF)}

The PBF area contains the Waste Experimental Reduction Facility, which processes lowlevel waste to reduce waste volume through sizing of metallic waste, compaction and incineration.

\section{Naval Reactors Facility (NRF)}

The NRF is operated by Westinghouse Electric Corporation for DOE's Pittsburgh Naval Reactors Office. From 1953 through May 1995, NRF prototypes served as a site for training Navy personnel who serve aboard nuclear-powered submarines and warships. At the Expended Core Facility, NRF also tests and examines naval reactor fuel components to improve current designs and to monitor the performance of existing reactors.

\section{Radioactive Waste Management Complex (RWMC)}

The RWMC's mission is to manage the disposal of low-level radioactive waste and the temporary storage of transuranic waste in an environmentally sound manner. The facility studies various strategies for the storage, processing and 
disposal of radioactive wastes. The Stored

Waste Examination Pilot Plant is used to nondestructively examine waste before it can be sent to the Waste Isolation Pilot Plant in New Mexico.

\section{Central Facilities Area (CFA)}

The CFA is headquarters for services at the INEEL. The area contains environmental monitoring, radiochemistry, radiation protection, quality assurance and calibration laboratories, vehicle and equipment pools, a cafeteria, fire and emergency medical facilities, warehouses, various craft shops, and a security facility.

\section{Idaho Falls}

Idaho Falls facilities include the INEEL Research Center, featuring programs in materials science, physical science, biotechnology, environmental science, and geotechnology. The Engineering Research Office Building, Willow Creek Building, Woodruff Avenue Complex, two DOE buildings, and other buildings house support personnel for the facilities at the INEEL.

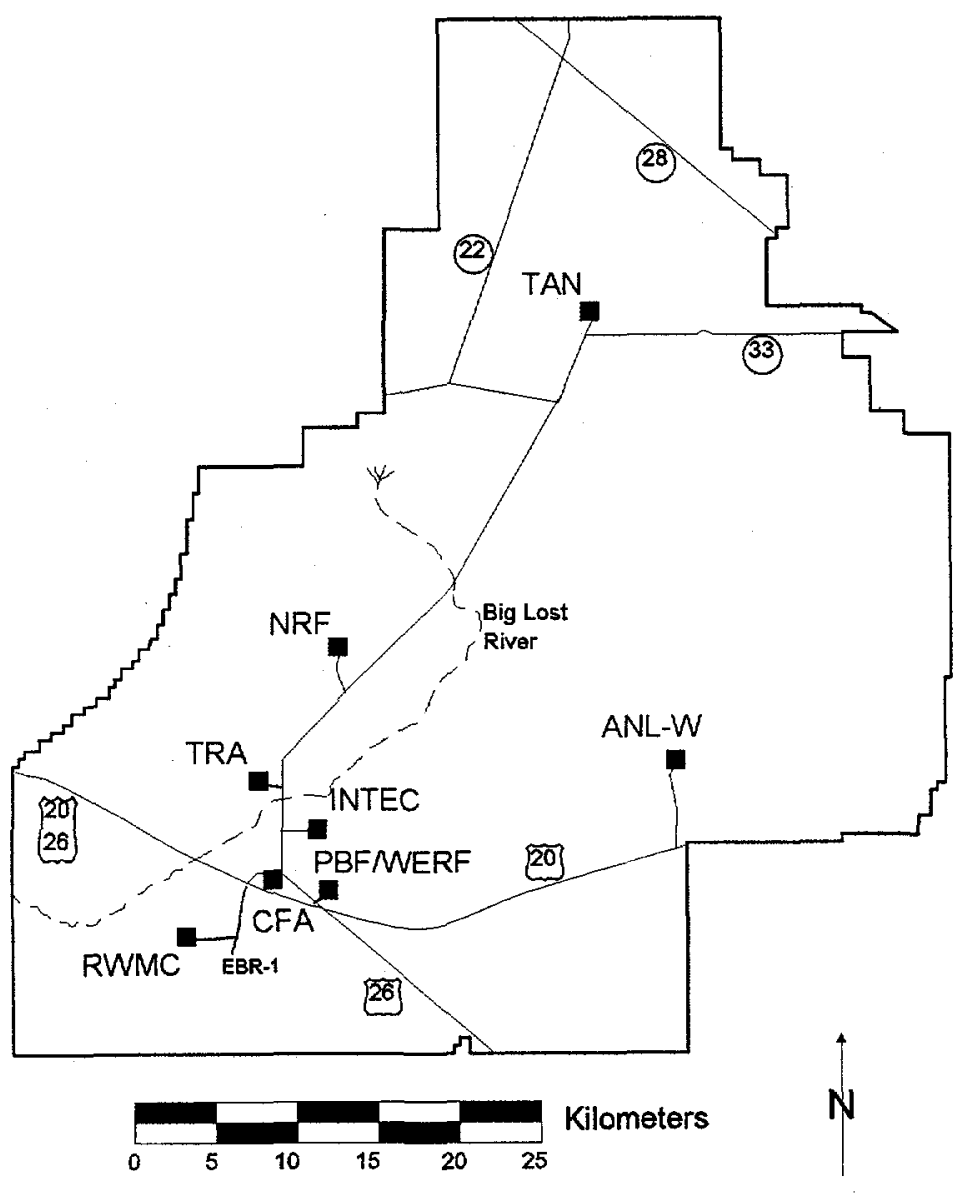

Figure 1-3. INEEL Facilities 


\section{Summary of Chapter 2 \\ Environmental Compliance Summary}

The Idaho National Engineering and Environmental Laboratory (INEEL) is committed to operating in compliance with all environmental laws, regulations, Executive Orders, U.S. Department of Energy (DOE) Orders, and compliance agreements with the Environmental Protection Agency (EPA) and the state of Idaho. This chapter provides a summary of the INEEL's current compliance status with major environmental statutes for the period January through December 1997 (Section 2.1) and summarizes major environmental issues and activities (Section 2.2). The current status of various permits are also described in this chapter (Section 2.3). 



\section{ENVIRONMENTAL COMPLIANCE SUMMARY}

\subsection{COMPLIANCE STATUS}

\section{Comprehensive Environmental Response, Compensation \& Liability Act (CERCLA)}

CERCLA provides the specific procedures to assess and remediate inactive waste sites where the release of hazardous substances has occurred. The INEEL was placed on the National Priorities List under CERCLA on November 29, 1989. Environmental restoration activities at the INEEL are being conducted in accordance with the Federal Facilities Agreement and Consent Order signed in December 1991 in consultation with the state of Idaho and EPA Region 10.

During 1997, investigations under the processes outlined in the 1991 Agreement continued to be streamlined. Limited field investigations, termed either Track 1 or Track 2, are used in lieu of the more extensive remedial investigation/feasibility study to evaluate many potential release sites. A Track 1 designation is used for potential release sites where existing data are expected to demonstrate that a site needs no further action. Track 2 denotes limited field data collection is necessary. After each limited investigation is completed, a determination is made by the Consent Order Project Managers that no further action is necessary, or that either proceeding with an interim cleanup action or further investigation under a remedial investigation/feasibility study is appropriate. Most currently scheduled Track 1 and Track 2 field investigations have been completed.

Cleanup milestones scheduled in the 1991 agreement were all met during 1997. All but one of the 10 Waste Area Groups (WAG) identified in the agreement have initiated a Comprehensive Remedial Investigative and Feasibility Study (RI/FS) which was intended as the last major investigation at each WAG. The Comprehensive RI/FS for WAG 2 (TRA) was completed by signing a Record of Decision in December 1997.

\section{Emergency Planning and Community Right-to- Know Act (EPCRA)}

The purpose of EPCRA is to provide the public with information about hazardous chemicals on the INEEL and to establish emergency planning and notification procedures to protect the public from chemical releases. This Act also contains requirements for periodic reporting on hazardous chemicals stored and/or used at the facilities. Executive Order 12856, "Federal Compliance with Right-to-Know Laws and Pollution Prevention Requirements," requires all federal facilities to comply with the provisions of this act (Table 2-1).

311 Report. Quarterly 311 reports were submitted to Local Emergency Planning Committees, the State Emergency Response Commission, and to local fire departments by January 1, April 1, July 1 , and October 1 in 1997 . These quarterly reports satisfy the 90-day notice requirement for new chemicals brought onsite.

312 Report. The Emergency and Hazardous Chemical Inventory (Tier II) Report for 1997 was transmitted to the planning and response agencies before March 1, 1998. This report identifies the types, quantities, and locations of hazardous and extremely hazardous chemicals stored at INEEL facilities that exceed CERCLA and Emergency Planning Act reporting thresholds.

313 Report. The Toxic Chemical Release Inventory Report was transmitted to EPA and the state of Idaho by July 1, 1997. The report identified quantities of toxic chemicals released to the environment by the INEEL during calendar year 1997. A report was prepared for one toxic chemical nitric acid - in 1997. 
TABLE 2-1. INEEL 1997 EMERGENCY PLANNING AND COMMUNITY RIGHT-TO-KNOW ACT (EPCRA) UPDATE

\begin{tabular}{lc} 
EPCRA 302-303: Planning Notification & Yes [ ] No [ ] Not Required [X] \\
\hline EPCRA 304: EHS Release Notification & Yes [ ] No [ ] Not Required [X] \\
EPCRA 311-312: MSDS /Chemical Inventory & Yes [X] No [ ] Not Required [ ] \\
\hline Extremely Hazardous Substances &
\end{tabular}

\section{Natural Resource Trusteeship \& Natural Resources Damage Assessment}

Executive Order 12580, Section 2(d), appoints the Secretary of Energy as the primary Federal Natural Resource Trustee for natural resources located on, over, and under land administered by DOE. Natural resource trustees act on behalf of the public when natural resources may be injured, destroyed, lost, or threatened as a result of the release of hazardous substances. In the case of the INEEL, other potential natural resource trustees with possible jurisdiction over trust resources are the state of Idaho, Department of Interior (Bureau of Land Management and U.S. Fish and Wildlife Service), and the Shoshone-Bannock Tribes.

Past releases of hazardous substances resulted in the INEEL's placement on the National Priorities List. These same releases create the potential for injury to natural resources. DOE is liable under CERCLA for damages to natural resources resulting from releases of hazardous substances to the environment. The Environmental Restoration Program is attempting to coordinate with DOE-ID cotrustees on any INEEL Natural Resource Damage Assessment issues arising as a result of the comprehensive RI/FS study for each Waste Area Group.

In April 1995, Lockheed Martin Idaho Technologies Company (LMITCO) and the Environmental Science and Research Foundation wrote a guidance manual for conducting screening level ecological risk assessments [Reference 2-1]. The manual was developed to streamline and standardize the ecological assessment process at the INEEL. It supports DOE schedules and milestones in the Federal Facilities Agreement/Consent Order for carrying out RI/FS activities at the INEEL.

Although the ecological risk assessment is a separate effort from the Natural Resources Damage Assessment, it is anticipated that the ecological assessment performed for CERCLA remedial actions can be used to help resolve many natural resource issues among trustees as well. The regulation allows for this substitution [Reference 2-2]. DOE-ID continues to submit documentation regarding four Waste Area Groups to the cotrustees.

\section{Clean Air Act}

The Clean Air Act sets standards for ambient air quality and for air emission of hazardous air 
pollutants. EPA is the federal regulatory agency of authority, but states may administer and enforce provisions of the act by obtaining EPA approval of a State Implementation Plan. Idaho has been delegated such authority.

The Idaho air quality program is primarily administered through the permitting process. Potential sources of air pollutants are evaluated against regulatory criteria to determine if the source is specifically exempt from permitting requirements, and if the source's emissions are significant or insignificant. If emissions are determined to be significant, several actions will occur:

- Self-certification that emissions are below any trigger level necessitating action by a regulatory agency;

- Request for a permit applicability determination from the regulatory agency;

- Request for a Permit to Construct; and

- Request for a Permit to Construct for sources of significant emissions through a Prevention of Significant Deterioration analysis.

Permitting actions for potential sources of air pollutants are discussed in Section 2.3.

Title V Operating Permit. Title V of the 1990 Clean Air Act Amendments required the EPA to develop a federally enforceable operating permit program for air pollution sources to be administered by the state and/or local air pollution agencies. The EPA promulgated regulations in July 1992 that defined the requirements for state programs. Idaho has promulgated regulations and EPA has given interim approval of the Idaho Title V Operating Permit program.

The INEEL Title V Air Operating Permit Application was submitted to the Idaho Division of Environmental Quality on July 28, 1995. The permit application was declared "administratively complete" on December 22, 1995. The reg- ulatory technical review of the application is not anticipated to begin until summer of 1999 , with a permit to be issued in 2000. An emission inventory of sources of air pollutants has been and will continue to be conducted with the inventory submitted to the regulatory agency annually. In addition, the INEEL prepared an addendum to the Title $\mathrm{V}$ application that updates emission sources.

The INEEL received one permit to construct during 1997 which provides for treating mixed debris waste at the INTEC New Waste Calcining Facility. Efforts are ongoing to evaluate release points and to ensure such sources are adequately described in existing permits and in the Title $\mathrm{V}$ application. A database which identifies all applicable air quality requirements was developed in 1997 and is currently undergoing review. The database will support the Title V Operating Permit, helping to identify requirements and to develop strategies for ensuring compliance.

\section{National Emission Standards for Hazardous Air Pollutants}

In June 1998, DOE-ID submitted the 1997 INEEL National Emission Standards for Hazardous Air Pollutants-Radionuclides report to EPA, DOE-Headquarters, and state of Idaho officials. Using the CAP- 88 computer model, the hypothetical maximum individual effective dose equivalent to a member of the public resulting from 1997 INEEL airborne radionuclide emissions (monitored, unmonitored, and diffuse sources) was $0.03 \mathrm{mrem} / \mathrm{yr}$. This dose was $0.3 \%$ of the regulatory standard of $10 \mathrm{mrem} / \mathrm{yr}$. The 1997 calculations with this code are discussed further in Chapter 8, Dose to the Public.

In addition to the radiological program, LMITCO operates an asbestos program. All renovations or demolitions of structures that involve asbestos must satisfy requirements of 40 CFR 61, Subpart M. During 1997, 13 nonscheduled renovation operations were carried out involving amounts less than the EPA threshold. 
There were 48 scheduled renovation or demolition operations that required EPA notifications (amounts above the EPA threshold); of these, 21 were LMITCO operations, and 27 were operations of subcontractors.

ANL-W also operates an asbestos program. In 1997, ANL-W conducted 31 planned asbestos removals and 45 unplanned removals.

\section{Clean Water Act}

The Clean Water Act, passed in 1972, established goals to control pollutants discharged to U.S. surface waters. Among the main elements of the act are effluent limitations set by the EPA for specific industry categories and water quality standards set by states. The Clean Water Act also provided for the National Pollutant Discharge Elimination System (NPDES) permit program, requiring permits for discharges from a point source into surface waters. DOE was issued NPDES storm water general permits for the discharge of storm water from industrial and construction activities at the INEEL in 1993.

Clean Water Act Section 404 Permits. In October 1994, the Army Corps of Engineers granted a 10-year Section 404 permit that authorizes DOE-ID to discharge dredged and fill material associated with the excavation of soil material in Spreading Area B. Borrow activities have ceased in this area since then. Currently, Spreading Area $\mathrm{B}$ is undergoing restoration activities including recontouring and revegetation.

Spill Prevention, Control and Countermeasure Plans. Only TAN, INTEC, and RWMC require Spill Prevention, Control, and Countermeasure Plans. The INEEL facilities were evaluated in 1997 in accordance with 40 CFR 112. The determination was made that all other facilities remain exempt. The plans were reviewed and updated as necessary.

\section{National Pollutant Discharge Elimination System Point Source Discharge Permits}

A National Pollutant Discharge Elimination System permit application is on file with EPA Region 10 for minor discharges from INTEC production wells to the Big Lost River. INTEC is required to comply with Idaho Water Quality Standards for these discharges.

Storm Water Discharge Permits for Industrial Activity. INEEL's General Permit for Storm Water Discharges Associated with Industrial Activity was issued in February 1993. The permit expired in September 1997. DOE-ID applied for continuance of the permit on September 5, 1997. The continuance will be in effect until a modified NPDES storm water multi-sector general permit for industrial activities is published in 1998. The INEEL Storm Water Pollution Pre-vention Plan (SWPPP) for Industrial Activities [DOE/ID-10431] was implemented in 1993. The plan provides for baseline and tailored controls and measures to prevent pollution of storm water. Annual evaluations are conducted by the SWPPP team to determine compliance with the plans and the need for revision.

The LMITCO Environmental Monitoring Unit monitors storm water in accordance with the permit requirements and with DOE Orders. Results from this monitoring in 1997 are provided in Chapters 4 and 5 .

The National Oceanic and Atmospheric Administration (NOAA) Air Resources Laboratory provides identification and notification of storm events. Storm water pollution prevention training is provided to INEEL personnel in accordance with the permit requirements.

\section{Storm Water Discharge Permit for Construc-} tion Activity. INEEL's General Permit for Storm Water Discharges from Construction Sites was issued in June 1993. The INEEL Storm Water Pollution Prevention Plan for Construction Activities (DOE/ID-10425) was distributed in January 1994. The plan provides for measures 
and controls to prevent pollution of storm water. Worksheets are completed for construction projects and appended to the plan. Inspections of construction sites are performed in accordance with permit requirements. The NOAA Air Resources Laboratory provides identification and notification of storm events. Under the permit for construction activities, storm water monitoring is not a requirement.

\section{Executive Order 11990-Protection of Wetlands}

The only area of the INEEL identified as jurisdictional wetlands is the Big Lost River Sinks. The U.S. Fish and Wildlife Service National Wetlands Inventory map is used as to identify potential jurisdictional wetlands and nonregulated sites with ecological, environmental, and future development significance. Currently, there are no identified operations at the INEEL that have a significant impact on jurisdictional wetlands. However, cattle grazing is conducted by private parties in the Big Lost River Sinks area under Bureau of Land Management permits.

\section{Executive Order 11988-Floodplain Management}

During the current year, the United States Geological Survey completed "The Birch Creek Report." This report addresses a simulation of water-surface elevations for a hypothetical 100year peak flow in Birch Creek at the INEEL (USGS Water Resources Investigations Report 97-4083) [Reference 6-6].

\section{State of Idaho Wastewater Land Application Permits}

DOE-ID has applied for state of Idaho Wastewater Land Application Permits for all existing land application facilities (e.g., percolation ponds and sewage treatment irrigation systems), and four permits have been issued. Applications for Wastewater Land Application Permits have been submitted to the Idaho Division of Environmental Quality for the Water
Reactor Research Test Facility Sewage and Process Ponds at Test Area North (TAN) and the Test Reactor Area (TRA) Chemical Waste and Cold Waste Ponds. The Argonne National Laboratory-West (ANL-W) Industrial Waste Pond and Conveyance Ditches application was submitted by DOE Chicago Operations Office to the state of Idaho. An application for the Naval Reactors Facility (NRF) Industrial Waste Ditch has also been submitted to the state for review.

A Final Wastewater Land Application Permit was issued in July 1997 for temporary land application at the TRA Sewage Treatment Plant. However, the system was never used, and the permit was cancelled.

\section{Resource Conservation and Recovery Act (RCRA)}

RCRA establishes regulatory standards for the generation, transportation, storage, treatment, and disposal of hazardous waste. The state of Idaho is authorized by EPA to regulate hazardous waste and the hazardous component of mixed waste at the INEEL. Mixed wastes contain both radioactive and hazardous materials. Radioactive wastes not containing hazardous materials are regulated by the Atomic Energy Act as administered through DOE Orders.

RCRA Notices of Violation (NOV). On August 21, 1997, DOE received an NOV from the November 18, 1996, inspection containing 135 violations and a fine of $\$ 892,725$. The violations cover four main areas: 1) releases of hazardous waste at TRA, 2) mismanagement of hazardous waste with the mercury retort, 3 ) waste determinations at the ARA and 4) waste determination and management at INTEC. A negotiation team has met several times with the state, and negotiations are continuing into early 1998.

Since the March 1996 NOV (resulting from an inspection in January 1996), both DOE and LMITCO have conducted several audits at the INEEL. These audits have resulted in a list of additional non-compliant issues. This list has 
been given to the state. In parallel with the negotiations concerning the August 21, 1997, NOV, DOE and LMITCO are negotiating a voluntary consent order to address these additional noncompliant issues.

RCRA Closure Plans. The state of Idaho approved the closure certifications and removal of the following units from the Part A permit:

- Naval Ordnance Disposal Area, January 1997;

- Evaporator at TAN 607A, February 1997;

- Hazardous Waste Storage at CFA, February 1997;

- Sodium Storage at TAN 647, June 1997;

- Waste Acid Calciner at the Specific Manufacturing Capability (SMC), September 1997; and

- Waste Stabilization and Container Storage at PBF, December 1997.

RCRA Reports. As required by the state of Idaho, DOE-ID submitted the Idaho Hazardous Waste Generator Annual Report for 1997. The report contains information on waste generation, treatment, recycling, and disposal activities at INEEL facilities for 1997.

DOE-ID submitted the INEEL 1997 Affirmative Procurement Report to EPA by December 1, 1997, as required by Section 6002 of RCRA and Executive Order 12780. This report provides information on the INEEL's procurement of products containing recovered, rather than virgin materials.

The INEEL RCRA permit for the Hazardous Waste Storage Facility at CFA and some areas at ANL-W requires submittal of an annual certification to the DEQ that the INEEL has a waste minimization program in place to reduce the vol- ume and toxicity of hazardous waste. The certification was submitted on July 1, 1997.

The Annual Reports on Treatability Studies for Calendar Year 1996 were submitted to the DEQ in March 1997. Reports were submitted for the INEEL and the INEEL Research Center Treatability Studies, as defined by the regulation [Reference 2-4], are those in which a hazardous waste is subjected to a treatment process to determine:

- whether the waste is amenable to the treatment process;

- what pretreatment, if any, is required;

- the optimal process conditions needed to achieve the desired treatment;

- the efficiency of a treatment process for a specific waste or wastes; and

- the characteristics and volumes of residuals from a particular treatment process.

The annual reports describe the types of studies performed on both hazardous waste and mixed waste, and the quantities of waste used in the studies for the previous calendar year. The reports also provide a brief description of studies planned for the current calendar year. A "treatability study" is not a means to commercially treat or dispose of hazardous waste.

\section{Federal Facilities Compliance Act}

The Federal Facilities Compliance Act, which amends RCRA, requires the preparation of site treatment plans for the treatment of mixed wastes at DOE facilities that store or generate mixed wastes. Mixed waste contains both hazardous and radioactive components. The INEL Proposed Site Treatment Plan formed the basis for state of Idaho and DOE-ID consent order negotiations for mixed waste treatment at the INEEL. The Federal Facility Compliance Act Consent Order and Site Treatment Plan was 
finalized and signed by the state of Idaho on November 1, 1995. See Section 3.2 for more information.

In November 1997, the annual report and update were submitted to the state for review, public review, and final approval. In December 1997, the state approved the update and report. The INEEL Site Treatment Plan Update has been distributed. In 1997, the INEEL treated 25 cubic meters of mixed waste from off-site sources.

\section{National Environmental Policy Act (NEPA)}

NEPA and the Council on Environmental Quality Regulations at 40 CFR 1500 require each federal agency to consider every significant aspect of the environmental impacts of its proposed actions, inform the public that the agency considered environmental concerns in its decision-making process, and inform the agency decision maker of the environmental impacts and public concern associated with a proposed action. DOE's NEPA implementing procedures are at 10 CFR 1021 as amended. DOE Order 451.1 assigns authorities and responsibilities for the NEPA process within DOE. DOE-ID specific processes are set forth in its NEPA Internal Scoping Procedures, Quality Program Plan and Public Participation Plan. The DOE-ID NEPA Compliance Officer and NEPA Planning Board implement the process

\section{The Advanced Mixed Waste Treatment Project Environmental Impact Statement} (EIS). The Notice of Intent to prepare an EIS was published in the Federal Register November 20, 1997 (62 FR 62025). Public scoping was conducted November 20, 1997, through January 9,1998 , with scoping meetings held in Idaho Falls and Boise, Idaho. The schedule is to publish the draft EIS in June and the final EIS in November 1998. For more information, refer to Section 3.2 of this report.
High-Level Waste Treatment and Facilities Disposition EIS. The Notice of Intent was published in the Federal Register September 19, 1997 (62 FR 49029). It provides background information, gives the purpose and need, and describes the proposed action and agency-identified alternatives. Public scoping was conducted from September 19, 1997, through November 24, 1997, during which time two public scoping meetings were held - one in Idaho Falls, and one in Boise, Idaho. Currently, the schedule is to issue the Draft EIS in February 1999, and the Final EIS in September 1999. See Section 3.2 of this report for more information.

\section{Environmental Assessments.}

Deactivation and Closure of Obsolete Spent Nuclear Fuel Processing. Storage, and Support Facilities at the Idaho Nuclear Technology and Engineering Center. The proposed action would deactivate the Fuel Processing Complex (CPP-601), Fuel Receipt and Storage Facility (CPP-603), Remote Analytical Facility (CPP-627), and Head End Processing Plant (CPP-640). The Environmental Assessment Determination for this proposed action was signed December 17, 1997. The schedule is to issue the EA for public review by April 30, 1998.

\section{Safe Drinking Water Act}

The INEEL operates 12 active public water systems. All INEEL facilities performed sampling of drinking water as required by the state and EPA.

The Safe Drinking Water Act was reauthorized on August 6, 1996. It establishes primary standards for drinking water delivered by systems that supply drinking water to 15 or more connections or 25 individuals for at least 60 days per year. The INEEL drinking water supplies meet those criteria and are classified as nontransient either noncommunity or transient noncommunity systems, because persons who use the water do so four or five days per week, but do not live at the Site. 
The bacteriological program for drinking water at the INEEL involves monthly and/or quarterly testing for coliform bacteria.

Because bacteriological contamination was found in the drinking water supply at TRA and Power Burst Facility (PBF) during 1996, a permanent disinfectant system for TRA and PBF was completed in the spring of 1997. All INEEL bacteriological monitoring conducted in 1997 (Chapter 6) tested negative for coliform bacteria.

\section{Toxic Substances Control Act}

The Toxic Substances Control Act, which is administered by EPA, requires testing and regulation of chemical substances that enter the environment. The act supplements sections of the Clean Air Act, the Clean Water Act, and the Occupational Safety and Health Act. Compliance with the act at the INEEL is primarily directed toward management of polychlorinated biphenyls (PCBs).

\section{Storage of PCB-Contaminated Materials.} DOE-ID continues to store radioactively contaminated PCBs at the INEEL. Negotiations between DOE and EPA resulted in a complexwide agreement (May 8, 1996) for storage longer than one year. DOE-ID and EPA Region 10 are in the process of developing an agreement for issues other than one-year storage of these materials. DOE-ID personnel met with EPARegion 10 personnel in November 1997. The issues discussed include characterization, inspections, labeling, storage, and treatment. Several of those issues related to management of CERCLA waste. Documentation has been submitted to EPA and negotiations have begun.

Federal Insecticide, Fungicide, and Rodenticide Act

The Federal Insecticide, Fungicide, and Rodenticide Act governs the registration and use of pesticides (i.e. fungicides, herbicides, insecticides, and rodenticides). The INEEL complies with the act's requirements pertaining to storage and application of pesticides. There were no activities or issues at the INEEL with respect to this statute during 1997.

\section{National Historic Preservation Act}

Preservation of historic properties on lands managed by DOE is mandated under Section 106 of the National Historic Preservation Act. The act requires that when any federal undertaking will have an adverse effect on historic property, the cognizant federal agency must enter into an agreement with the state Historical Preservation Officer for the purpose of mitigating those adverse effects.

A comprehensive draft Historic Context of the INEEL was prepared in 1997, and is currently under review by the State Historical Preservation Officer. This Historic Context contains a historic evaluation of all properties built on the INEEL under the DOE-ID's authority, and provides the background with which to assess their historic significance. It will be used to guide a more comprehensive approach to managing the preservation and documentation of buildings scheduled to be modified or dismantled.

Draft Tribal Consultation Procedures were developed in partnership with the Tribes. These procedures provide clarity and guidance to ensure continued good communication between the Tribes, DOE and LMITCO regarding cultural resource management on the INEEL.

\section{Native American Grave Protection and Repatriation Act}

The INEEL is located on the aboriginal territory of the Shoshone people. The Shoshone-Bannock Tribes are major stakeholders in INEEL activities. They are particularly concerned with how the remains of their ancestors and culture are treated by DOE-ID and its contractors. The Native American Graves Protection and Repatriation Act provides for the protection of Native American remains and the repatriation of human remains and associated burial objects. Repatria- 
tion refers to the formal return of human remains and cultural objects to the tribes with whom they are culturally affiliated.

The State Historic Preservation Office and DOE-ID have been working closely to develop protocols based on the repatriation efforts for human remains found on the INEEL in 1995. Draft procedures have been formulated to assist in future repatriations on the INEEL, and are being used to guide this most recent repatriation effort.

Human remains were discovered at the Waste Experimental Reduction Facility during the summer of 1996; however, cultural affiliation could not be determined. DOE-ID and the Tribes are working closely and carefully to determine how to proceed. Resolution is still in process.

\section{Endangered Species Act}

The Environmental Science and Research Foundation conducts ecological research, field surveys, and NEPA evaluations regarding ecological resources. Particular emphasis is given threatened and endangered species and species of special concern identified by the U.S. Fish and Wildlife Service. Although sightings of wolves (Canis lupus), an endangered species, on the INEEL have been sporadically reported since 1993, none were reported during 1997. Nor were any Ute's ladies tresses (Spiranthes diluvialis) reported. It is unlikely suitable habitat (wet meadows) exists on the INEEL long enough each year to support this threatened species. Two bald eagles (Haliaeetus leucocephalus), a threatened species, were sighted on the INEEL during the 1997 mid-winter INEEL raptor count. Research and monitoring continued on several species of special biological, economic, and social concern, including Townsend's big-eared bat (Corynorhinus townsendii), pygmy rabbit (Brachylagus idahoensis), burrowing owl (Speotyto cunicuilaria), sage grouse (Centrocercus urophasianus), elk (Cervus elaphus) and pronghorn antelope (Antilocapra americana). Summaries of these and other research projects can be found in Reference 2-5.

\subsection{OTHER MAJOR ENVIRONMENTAL ISSUES AND ACTIVITIES}

\section{Litigation Issues}

Fort St. Vrain Litigation. On February 9, 1996, DOE and the Public Service Company of Colorado signed a settlement that allows continued safe storage of spent nuclear fuel from the Fort St. Vrain power reactor near Platteville, Colorado, until a permanent repository becomes available. The agreement meets one of the requirements of the October 1995 spent fuel agreement between DOE, the state of Idaho, and the U.S. Navy. Under the agreement, spent nuclear fuel from Fort St. Vrain can only be shipped to the INEEL if a permanent repository or interim storage facility located outside Idaho has been opened and is accepting fuel from the INEEL. In that case, spent nuclear fuel from Fort St. Vrain could be shipped to the INEEL for the purpose of preparing it for disposal or storage out-of-state. The Nuclear Regulatory Commission is processing an application for the transfer of the NRC license from Public Service Company to DOE.

The out-of-court settlement between DOE and the Public Service Company resolves the company's claims against DOE emanating from the 1965 contract. The Public Service Company claimed the contract obligated DOE to receive spent nuclear fuel from the Fort St. Vrain reactor for storage. However, DOE was unable to fulfill the contract because of the legal challenges to spent nuclear fuel storage at the INEEL. The utility company subsequently constructed and now operates a Nuclear Regulatory Commissionlicensed fuel storage facility located adjacent to the former Fort St. Vrain power plant. In lieu of accepting the spent nuclear fuel for storage in Idaho, DOE has taken title to the spent fuel and will pay the Public Service Company \$16 million to settle the claim. Public Service Company personnel will continue to manage the fuel for 
DOE under its current storage license until it has been transferred to DOE. At that time, DOE will take title to the facility and begin managing it. It is anticipated that the license transfer will take place on or about August 7, 1998.

\section{Environmental Impact Statement Litigation.} In 1993, in a lawsuit brought by the state of Idaho, the U. S. District Court ordered DOE to prepare an EIS on the proposed shipment of spent nuclear fuel from Fort St. Vrain to Idaho and the associated impacts of storing this fuel at the INEEL.. On August 10, 1995, the Snake River Alliance Education Fund filed a separate lawsuit challenging the adequacy of the same EIS. Relief requested by the plaintiff was an injunction as well as a "reversal" of the entire Record of Decision and a rewrite of the EIS. On March 31, 1998, the Court granted DOE's motion for summary judgement and denied the Snake River Alliance Education Fund's partial motion for summary judgment, which dismisses the lawsuit.

CERCLA Claim. Cowboy Oil Company filed a lawsuit for recovery of response costs under CERCLA. Third party plaintiff Cowboy Oil was sued for transporting used oil for recycling to the Ekotek/Petrochem Superfund Site in Salt Lake City, Utah. EG\&G (previously the DOE's prime contractor for the INEEL) had arranged with Cowboy Oil to transport their used oil for disposal, and Cowboy Oil alleges EG\&G and other third party defendants are liable for contribution under Section 113(f) of CERCLA. The plaintiff has demonstrated no basis for liability at this point. DOE is attempting to work toward settlement with the plaintiff's attorneys.

\section{Ground-water Monitoring Program Activities}

The INEEL Ground-water Monitoring Plan establishes a programmatic framework for ensuring compliance with all state, federal, and DOE ground-water-related standards. In accordance with DOE Order 5400.1, the plan documents local and regional hydrologic regimes, known and potential sources of ground-water contamination at the INEEL, and the monitoring networks and sampling programs necessary to evaluate the effects of the INEEL's activities on the local and regional ground-water resources.

The INEEL Ground-water Monitoring Program was designed using a three-tiered approach which integrates "Regional," "Area-specific", "Facility-specific" and "Unit-specific" monitoring networks. These networks are being installed and ground-water monitoring schedules are being implemented using a phased approach. The regional monitoring network is mostly in place and is being implemented by the USGS as part of their ongoing program which has been conducted since 1949. The development of area-specific monitoring networks was initiated in 1993 and networks have been completed at the Auxiliary Reactor Area, Special Training Facility, PBF, and INTEC. Area-specific monitoring networks are being installed in accordance with the INEEL Ground-water Monitoring Plan implementation schedule. Unit- and facility-specific monitoring networks were designed to provide leak detection. These wells are designed, installed, and monitored on an as-needed basis.

In 1997, compliance ground-water monitoring was conducted at TAN and INTEC as required by the waste water land application permit. Observational ground-water monitoring was conducted by the USGS in accordance with its Memorandum of Agreement with DOE-ID (see Section 6), and ground-water monitoring and characterization were conducted by the Environmental Restoration program in accordance with the INEEL Federal Facility Agreement and Compliance Order.

\section{Health Studies}

The Department of Energy and the INEEL have a medical surveillance program to monitor the health of current workers. The program is based on routinely collected health data, such as recordable injuries and illnesses specified by the Occupational Health and Safety Administration. 
The program will help identify emerging health issues at the INEEL.

A medical surveillance program for former workers at the INEEL was begun in 1997. The program, required by Section 3162 of Public Law 102-484, will evaluate the long-range health conditions of former employees who may have been subject to significant health risks from exposure to hazardous substances as a result of their employment at the INEEL. A Phase I pilot project is being carried out by a group of investigators consisting of the Oil, Chemical, and Atomic Workers International Union, Mt. Sinai School of Medicine, the University of Massachusetts at Lowell, and Alice Hamilton College.

Researchers from the Boston University School of Public Health, in cooperation with the National Institute of Occupational Safety and Health (NIOSH), are investigating the effects of workforce restructuring (downsizing) in the nuclear weapons industry. The health of displaced workers will also be studied.

In August 1996, the DOE and the Department of Health and Human Services revised their Memorandum of Understanding under which the Department of Health and Human Services conducts and manages all epidemiological studies at DOE facilities. Two study areas, dose reconstruction and worker epidemiology, are discussed below.

The Centers for Disease Control and Prevention $(C D C)$ have established a public advisory group, the INEEL Health Effects Subcommittee. The Subcommittee meets four times a year, usually in different cities in Idaho. This group will provide recommendations to the $\mathrm{CDC}$ and to the Agency for Toxic Substances and Disease Registry (ATSDR) regarding INEEL health studies performed under two Memorandums of Understanding.

INEEL Dose Reconstruction Study. The INEEL Environmental Dose Reconstruction Project is being conducted by the National Center for
Environmental Health of the CDC. Phase 2 began in 1996 with the start of a task to determine the feasibility of estimating doses to the offsite public from toxic chemicals released from the INEEL. A similar task for radionuclides began near the end of 1997 .

\section{Epidemiological Study of Workers at the} INEEL. The INEEL Epidemiological Study of Workers, which will evaluate patterns of mortality in all workers at the INEEL since 1949, is being conducted by NIOSH of CDC. NIOSH is conducting an all-cause cohort mortality study. and will evaluate the feasibility of a prospective cancer incidence study among INEEL employees. Exposures of interest are external ionizing radiation and a variety of chemicals. The first phase of the study, analysis of standardized mortality ratios, is planned for completion by December 1998.

Under a NIOSH cooperative agreement, the epidemiologic evaluation of childhood leukemia and paternal exposure to ionizing radiation now includes the INEEL, as well as other DOE sites

CERCLA Health Assessment. The ATSDR began a Health Assessment of the INEEL Site as required by CERCLA for all sites listed on the CERCLA National Priorities List. The focus of the Health Assessment is to provide information that would further the goal of preventing and mitigating exposures to hazardous substances released to the environment. The majority of the Health Assessment is expected to be completed in fiscal years 1998 and 1999 and is funded by DOE.

\section{Environmental Occurrences}

Several small spills occurred at the INEEL during 1997 that were not reportable under environmental regulations. These included small releases of diesel fuel, sulfuric acid, nitric acid, ethylene glycol and oil.

During calendar year 1997, there were six reportable releases. These notifications were 
made in accordance with DOE and CERCLA requirements. Five of the six incidents involved petroleum spills which were not cleaned up within 24 hours; these spills were subsequently addressed. The sixth release was the discovery of corroded paint cans in soil. The paint was suspected to contain lead. The area of impacted soil was removed for disposition.

\section{Environmental Oversight \& Monitoring Agreement}

The Environmental Oversight and Monitoring Agreement between DOE-ID, DOE-Naval Reactors Idaho Branch Office, and the state of Idaho maintains the state's program of independent oversight and monitoring established under the agreement first creating the INEEL Oversight Program. The main objectives as established under the second five-year agreement are to:

- Assess the potential impacts of present and future DOE activities in Idaho;

- Assure citizens of Idaho that all present and future activities in Idaho are protective of the health and safety of Idahoans and the environment; and

- Communicate the findings to the citizens of Idaho in a manner that provides them the opportunity to evaluate potential impacts of present and future DOE activities in Idaho.

The State Oversight Program activities produced many accomplishments in 1997, due in large part to a coordinated working relationship with DOE, the INEEL contractors, the ShoshoneBannock Tribes, USGS, NOAA, and Idaho State University.

\section{Monitoring and Surveillance Committee} (MSC). The INEEL Monitoring and Surveillance Committee was created in March 1997, and has held monthly meetings since then to coordinate monitoring activities between the several groups involved in INEEL onsite and offsite environmental monitoring. This standing committee brings together representatives from DOE-Idaho, DOE-Chicago, DOE-Naval Research, LMITCO, ANL-W, Westinghouse, the Shoshone-Bannock Tribes, the Idaho Department of Environmental Quality, the Idaho INEEL Oversight Program, NOAA, USGS, and the Environmental Science and Research Foundation. The MSC has served as a valuable forum to review monitoring, analytical, and quality assurance methodologies, to coordinate efforts, and to avoid unnecessary duplication. All INEEL monitoring groups have benefitted from participation.

Environmental Surveillance Program. The Environmental Surveillance Program is intended to verify and supplement existing surveillance programs operated by DOE contractors. The program's approach is designed to accomplish environmental verification.

A research study regarding atmospheric tritium measurements was continued during 1997 in conjunction with Idaho State University and LMITCO. The study will evaluate and attempt to improve current methods of field sampling and laboratory analysis for environmental levels of atmospheric tritium. The results of this study will enable the State Oversight Program to enhance its current sampling methods and ensure comparable results with other INEEL monitoring programs. State Oversight completed the installation of three community monitoring stations surrounding the INEEL in 1997. One station is located in Idaho Falls along the Snake River Greenbelt, one in Mud Lake, and one at the rest: stop beside U.S. Highway 20/26 on the INEEL. A fourth community monitoring station is operated by the Shoshone-Bannock Tribes but provides the same monitoring parameters as those operated by the State Oversight Program. Those monitoring stations provide real time monitoring data to the state as well as the public via on-site visits and through access on the Internet.

Emergency Response and Preparedness Program. The agreement requires assistance to local authorities with emergency preparedness. DOE has assisted the State Oversight Program in 
establishing a statewide Interagency Planning Group. The group provides a process for coordination of emergency preparedness issues and concerns among the various state agencies as well as increased communication among the various organizations. A five-phase radiological emergency response plan and emergency response training has been cooperatively established with the State Oversight Program to assist the local governments to meet local emergency response needs. The community monitoring stations have helped enhance the monitoring parameters and locations of meterological conditions for use in emergency planning as well as emergency response. This information is available to the state of Idaho as well as the local emergency response personnel for use in actual emergencies and for use in drills and exercises.

Impact Assessments Program. The Impacts Assessment Program produces scientific validation through independent risk assessment of current and future operations specific to Idaho. A collaborative effort improves and scientifically validates DOE's processes. The activity allows the state and DOE to more effectively and efficiently plan future needs in surveillance and emergency response.

\section{Citizens Advisory Board}

The INEEL Citizens Advisory Board, formerly called the Site Specific Advisory Board, was formed in March 1994. Its charter is to provide input and recommendations on environmental management strategic decisions that impact future use, risk management, economic development, and budget prioritization activities

During 1997, five members rotated off the Board and were replaced with five new members, including a new representative appointed by the Shoshone-Bannock Tribes. The board held its biannual election for chair and vice-chair. Mr. Charles Rice was re-elected as the chair, and Dr. Maxine Dakins was elected as the vice-chair. The board had a productive year in 1997, producing 15 recommendations and one joint state- ment with the Hanford Advisory Board. The 15 recommendations are provided in the board's 1997 Annual Report, and concern the following:

- INEEL High Level Waste Program;

- DOE Strategic Laboratory Missions Plan;

- Waste Isolation Pilot Plant Supplemental EIS;

- Use of Video Conferencing for Public Hearings;

- Environmental Documentation Process for the Advanced Mixed Waste Treatment Project;

- DOE-ID Environmental Management FY99 Budget Priorities;

- Mixed Low-Level Waste Management;

- Low-Level Waste Management;

- Waste Area Group 3 Fact Sheet;

- Waste Area Group 3 Remedial Investigation/Feasibility Study;

- TNEEL FY99 Budget Priorities Summary (Advice);

- Draft Surplus Plutonium Disposition EIS;

- Opening of the INEEL Technical Library to the public;

- High Level Waste and Facilities Disposition EIS; and

- Curricula Development and Continuing Education Opportunities for Elementary and Secondary School Teachers in Idaho. 


\subsection{PERMITS}

Permits that were granted to the INEEL in 1997 and those for which applications have been submitted are summarized in Table 2-2.

In 1997, the RCRA units with Hazardous Waste Permits included:

- Radioactive Sodium Storage Facility at ANL-W;

- Radioactive Scrap and Waste Facility at ANL-W;

- Sodium Process Facility at ANL-W;
- Hazardous Chemical Waste Handling and Neutralization Facility at INTEC;

- CPP 666 Fluorinel Disolution Process Cell Container Storage at INTEC;

- Debris Treatment Processes Holdup and Collection Tanks at INTEC;

- Intermediate-Level Transuranic Storage Facility, Pad 2 at RWMC;

- Waste Storage Facilities (Type I and Type II) at RWMC; and

- Stored Waste Examination Pilot Plant at RWMC.

\begin{tabular}{|c|c|c|c|}
\hline \multicolumn{4}{|c|}{ TABLE 2-2. PERMIT SUMMARY FOR THE INEEL (1997) } \\
\hline Permit Type & Issuing Agency & Granted & Pending \\
\hline $\begin{array}{l}\text { Air } \\
\text { Self-Certify }\end{array}$ & & & \\
\hline \multirow{2}{*}{$\begin{array}{l}\text { Self-Certify } \\
\text { Permit to Construct }\end{array}$} & None & 21 & 0 \\
\hline & DEQ & 3 & 1 \\
\hline Exempt/PAD & DEQ & 8 & 2 \\
\hline NESHAPs ${ }^{b}$ & EPA Region 10 & 0 & 0 \\
\hline Operating Permit & DEQ & 0 & 1 \\
\hline \multicolumn{4}{|l|}{ Ground Water } \\
\hline Injection Well & Dept. of Water Resources & 8 & 0 \\
\hline Well Construction & Dept. of Water Resources & 1 & 0 \\
\hline \multicolumn{4}{|l|}{ Surface Water } \\
\hline NPDES-Point Source & EPA Region 10 & 0 & 1 \\
\hline NPDES-Storm Water & EPA Region 10 & 2 & 1 \\
\hline & DEQ & 4 & 5 \\
\hline 404 Permit & Corps of Engineers & 1 & 0 \\
\hline Industrial Waste Acceptance Form & City of Idaho Falls & 16 & 1 \\
\hline \multicolumn{4}{|l|}{ RCRA } \\
\hline Part A & State of Idaho & 1 & 0 \\
\hline Part $B^{c}$ & State of Idaho & 7 & 17 \\
\hline $\begin{array}{l}\text { Permit Applicability Determination } \\
\text { National Emissions Standards for } \\
\text { F }\end{array}$ & $\begin{array}{l}\text { Pollutants. } \\
\text { eral volumes. }\end{array}$ & & \\
\hline
\end{tabular}




\section{Summary of Chapter 3 \\ Environmental Program Information}

This chapter describes activities and milestones within major environmental programs at the Idaho National Engineering and Environmental Laboratory (INEEL). The U.S. Department of Energy (DOE) is developing an environmental management system for the INEEL, based on an international standard known as ISO 14001 (Section 3.1). The Environmental Restoration Program section (Section 3.2) describes the activities within the 10 Waste Area Groups, ranging from limited field investigations to major RI/FS. The goal of the Waste Management Program (Section 3.3) is to manage wastes at the INEEL in such a manner as to ensure that workers and the public are protected, and that there is no further impact to the environment.

Other programs at the INEEL contain environmental components (Section 3.4). Public education programs and publications designed to inform the public about the INEEL activities are also discussed in this section.

Several groups perform environmental monitoring of various pathways by which members of the public might be impacted by operations at the INEEL (Section 3.5). During 1997 major environmental surveillance activities at the INEEL were performed by the Environmental Science and Research Foundation, Lockheed Martin Idaho Technologies Company (LMITCO), the U.S. Geological Survey (USGS), the National Oceanic and Atmospheric Administration (NOAA), and the state of Idaho. 



\section{ENVIRONMENTAL PROGRAM INFORMATION}

\subsection{ENVIRONMENTAL MANAGEMENT SYSTEM (EMS)}

In 1997, DOE-ID and LMITCO made the decision to improve existing management systems. Applying the management systems approach to the environmental arena is aligned with and complementary to the quality improvement effort being undertaken by DOE-ID. The Environmental Management System (EMS) will meet the requirements of ISO 14001, an international voluntary standard for environmental management systems. This standard is being vigorously embraced worldwide and within the DOE complex. Certification under ISO14001 will demonstrate our commitment to improved environmental performance to our regulators, the public, and the international business community.

An EMS provides an underlying structure to make the management of environmental activities more systematic and predictable. The EMS focuses on three core concepts: pollution prevention, environmental compliance, and continuous improvement. The primary system components are (1) Environmental Policy, (2) Planning, (3) Implementation and Operation, (4) Checking and Corrective Action, and (5) Management Review. DOE-ID is pursuing an EMS enhancement development initiative for the Idaho workforce and LMITCO is working on a parallel effort for the INEEL.

This effort will be integrated with the Safety Management Systems (SMS) and quality initiatives currently being implemented by DOE-ID and LMITCO. Both the EMS and SMS are based on the "plan, do, check, act" concept; both involve work planning, analysis of hazards and impacts, operational controls, feedback, and continuous improvement. DOE-ID and LMITCO already have in place many SMS/EMS systems. However, linkages can be improved and redundancies can be minimized. A primary goal of both DOE-ID and LMITCO is for work planning and execution to proceed with full consideration of environmental, safety, and health objectives and targets. A joint registration will be sought in early 2000 .

\subsection{ENVIRONMENTAL RESTORATION PROGRAM}

\section{General Information}

A common perception of environmental restoration investigative and remedial activities at DOE and other government sites is that all parts of the process are expensive and time-consuming. However, during recent years, streamlining environmental restoration activities at the NNEEL by DOE, the Environmental Protection Agency (EPA), and the state of Idaho has saved millions of dollars. This streamlining was possible due to the flexibility and management principles established under the Federal Facilities Agreement and Consent Order such as:

- Making cleanup decisions as soon as sufficient data are present;

- Using existing data whenever possible;

- Avoiding duplication of analyses and documentation; and

- Matching the level of investigation to the level of complexity of each release site.

During the six years since the agreement was signed, the INEEL has cleaned up sites containing asbestos, petroleum products, acids and bases, radionuclides, unexploded ordinance and explosive residues, PCBs, heavy metals and other hazardous wastes. The INEEL Environmental Restoration Program has maintained significant progress in accomplishing its goals. As of December 1997, a tally of environmental restoration activities at the INEEL showed:

- 15 Records of Decision have been signed; 
- 18 removal actions were completed;

- 8 major investigations were in progress;

- 4 interim actions were completed; and

- 8 final actions were completed or fully operational.

Comprehensive remedial investigation/feasibility studies are under way in all Waste Area Groups. The comprehensive investigations, which take an average of forty months to complete, accomplish the following:

- Determine the cumulative risks for an entire Waste Area Group by assessing the combined impact of all release sites within that group;

- Review assumptions used in each previous investigation, including "No Further Action" sites, Track 1 and 2 limited field investigations, RI/FS, and interim actions;

- Identify data gaps and recommend actions such as field sampling or historical document research to resolve questions;

- Perform a feasibility study to evaluate remedial alternatives for the entire Waste Area Group;

- Develop a proposed plan presenting the alternatives and recommending a preferred alternative; and

- Develop a record of decision selecting the alternative and resolving public comments.

The general procedure for all comprehensive investigations begins with developing a Work Plan outlining potential data gaps and release sites which may require more field sampling. When the investigation is complete, DOE, EPA and the state hold public comment meetings on the proposed cleanup alternative. The first proposed plan for cleanup resulting from a compre- hensive remedial investigation/ feasibility study was released for public comment on March 9, 1997. The agencies signed the Record of Decision for the Waste Area Group 2 documenting the final cleanup decision. The status of each Waste Area Group was given in the 1997 edition of the INEEL Reporter Supplement: Citizen's Guide - An Update on INEEL's Environmental Restoration Program, available by calling 1-800708-2680.

\section{Waste Area Group 1-Test Area North (TAN)}

\section{TAN Ground-water Remediation.}

Cleanup of the TAN injection well began in 1993. The well was used from 1953 until 1972 to inject liquid wastes into the fractured basalt of the Snake River Plain Aquifer. The wastes included organic and inorganic compounds and low-level radioactive wastes combined with industrial and sanitary waste waters. The resulting plume contaminated some of the drinking water wells used by TAN workers. The drinking water has been treated to meet drinking water standards, and untreated water is not accessible.

An interim action to remove the source of contamination and to prevent further impact to the aquifer began in 1994. A subcontract was awarded for the design, construction, and operation of a Ground-water Treatment Facility. The objective was to pump and treat the TAN injection well water to remove trichloroethylene, the primary contaminant of concern. However, after operating the treatment facility for several months, the agencies learned that contaminant levels were higher than expected, other contaminants were present, and that the facility could not remove some of these additional contaminants.

The final RI/FS addressing the entire contamination plume was completed in 1994. The TAN ground water final remedial action Record of Decision was approved in August 1995. The treatment facility used in the interim action was purchased from the subcontractor and has been surging and stressing the injection well and providing hydraulic containment since soon after the 
Record of Decision was signed. The treatment plant began continuous operations in November 1996 and has since treated over 79.5 million liters (21 million gallons) of water. The remedy calls for containing the contaminated ground water and reducing contamination levels to below maximum contaminant levels within 100 years. The decision also calls for the evaluation of new, innovative technologies, such as in-situ bioremediation and in-situ chemical oxidation. Plans for 1998 include continuing hydraulic containment and surge and stress at the injection well, and evaluating bioremediation and chemical oxidation as possible enhancements to pump and treat.

\section{Waste Area Group 1 Comprehensive RI/FS.} This investigation began during 1995. DOE-ID submitted the draft Final Work Plan to EPA and the state of Idaho on January 24, 1996. Eleven operable units and 94 potential release sites, including the V-tanks (tanks containing hazardous, PCB, and radioactive wastes) were evaluated during the final investigation. The RI/FS was finalized on November 14, 1997. Activities planned for 1998 include completing the Proposed Plan and Record of Decision and completing treatability studies on the V-tank contents.

\section{Waste Area Group 2-Test Reactor Area (TRA)}

Perched-water System. The perched water under TRA is a zone of ground water sitting on a relatively impermeable layer of clay $100 \mathrm{~m}$ (330 $\mathrm{ft}$ ) above the Snake River Plain Aquifer. It was formed over time by percolation from the TRA waste water disposal ponds. The INEEL Project Office of the USGS has monitored perched water in the TRA area for many years. LMITCO personnel began routine compliance monitoring following closure of the TRA Radioactive Waste Pond in 1993. The agencies will use the monitoring data to determine whether contaminant concentrations are behaving as predicted in the perched water.
Waste Area Group 2 Comprehensive RI/FS. Activities performed in 1997 related to the comprehensive investigation for Waste Area Group 2 included completing the RI/FS. The Record of Decision was signed December 1997. It documented that remedial action will be taken at eight of the 55 potential release sites at WAG 2 . Remedial Design will occur through 1998 with the majority of Remedial Action being completed in 1999.

\section{Waste Area Group 3-Idaho Nuclear Technol- ogy and Engineering Center}

\section{Waste Area Group 3 Comprehensive RI/FS.}

The Draft Comprehensive RI/FS report was submitted to the EPA and the state of Idaho in June 1997 for review and comment. Comments on the draft document were received in September 1997, and the draft final RI/FS was sent to the EPA and state of Idaho in November 1997. The RI/FS become final in December 1997. The results of ground-water modeling, risk assessment, and evaluation of remedial action alternatives are contained in the RI/FS. The Proposed Plan will be finalized in September 1998 and a public comment period held during September and October 1998.

\section{Waste Area Group 4-Central Facilities Area (CFA)}

\section{Simulated Calcine/Mercury-Contaminated} Soil Removal Action. Proper disposal methods were used for all secondary wastes generated by this removal action during the year. The summary report, which discusses the project, was initiated and is scheduled to be completed in 1998. The materials associated with this project were excavated from a dry pond used in the $1950 \mathrm{~s}$ and 1960s to dispose of materials from the Chemical Engineering Laboratory during development of a nuclear waste calcining process. The excavation, treatment, storage, and disposal were performed under a Comprehensive Environmental Response, Compensation and Liability Act removal action associated with the Operable Unit 4-05 Track 2 investigation. 
Miscellaneous Sites 1996 Removal Action. The summary report was completed, thus concluding all work on this project which remediated one site contaminated with petroleum products and two sites contaminated with lead.

Miscellaneous Sites 1997 Removal Action. A Comprehensive Environmental Response, Compensation and Liability Act Non-Time Critical Removal Action was performed at five WAG 4 sites in 1997. Petroleum-contaminated materials, primarily soils, were cleaned up at three sites, and two dry-wells from the other two sites were removed for disposal. Approximately $8,950 \mathrm{~m}^{3}$ $\left(11,700 \mathrm{yd}^{3}\right)$ of petroleum contaminated soils were excavated and transported to the CFA Land Farm for treatment. Before the excavations were backfilled, confirmation samples were taken to ensure that cleanup goals were met. The two dry-wells were excavated and the dirt disposed of at the CFA Landfill after sampling results confirmed that the dry-wells were not contaminated.

Landfills I, II, and III Remedial Action. The final work to complete this remedial action was performed early in the year and routine groundwater monitoring has been performed quarterly throughout the year. Periodic maintenance and monitoring will be performed as required by project documentation.

As specified in the Record of Decision for the CFA Landfills I, II, and III, Operable Unit 4-12, the remedy consisted of native soil covers, access controls such as fencing and signs, and environmental monitoring. Minimizing infiltration of water through the wastes that could facilitate migration of contaminants to the Snake River Plain Aquifer is the main purpose of the soil covers, which also mitigate direct contact with the wastes in the landfills.

Used as recently as 1984 , the landfills accepted municipal-type and industrial wastes generated from INEEL operations. Wastes disposed to the landfills included cafeteria garbage, trash sweepings, weeds, grass, asphalt, asbestos, scrap lumber, and metal. DOE-ID, EPA, and the state agreed to take action to reduce any potential of ground-water contamination from the landfills and risks associated with exposure to the waste.

Waste Area Group 4 Comprehensive RI/FS. The Remedial Investigation Work Plan for this investigation, which began in 1996, was completed in the spring of 1997. Field sampling was conducted during the summer and by late fall the data were being evaluated for use in the Remedial Investigation/Baseline Risk Assessment. In total, 13 operable units and 52 potential release sites are being examined during this investigation.

\section{Waste Area Group 5-Power Burst Facility (PBF)/Auxiliary Reactor Area (ARA)}

\section{Stationary Low-Power Reactor-1/Boiling} Water Reactor Experiment-I. Although these two reactor burial sites are located in different Waste Area Groups, similarities led to combining them for the investigative and remedial processes.

The Stationary Low-Power Reactor-1 facility was a small nuclear power plant designed for the military to generate electric power and heat for remote installations. It accidentally achieved a critical reaction on January 3, 1961, resulting in a steam explosion that destroyed the reactor and killed the three operators on duty. To minimize: radiation exposure to site workers and the public, a reactor burial ground was built for the contaminated debris near the original reactor site. Disposing of the material onsite was preferable to transporting the radioactive debris over $26 \mathrm{~km}$ (16 mi) of public highway to the Radioactive Waste Management Complex.

The Boiling Water Reactor Experiment-I facility was a small reactor for testing boiling water reactor technology. It was intentionally destroyed in 1954 after completion of its mission. The destruction of the reactor contaminated about 0.8 ha ( 2 acres) of surrounding terrain. Much of the reactor debris was buried in place, and the area was covered with about $15 \mathrm{~cm}$ (6 in) of gravel to reduce radioactivity levels. 
Capping of these sites was completed in 1996. Access and land use to industrial applications is restricted for at least 100 years. Reseeding of the disturbed areas within the exclusion zones and support areas at both sites, and recontouring and reseeding of construction roads in and around cap material source locations was completed in April 1997. The Remedial Action Report was completed in September 1997.

ARA. A Time Critical Removal Action was conducted at the ARA-I facility in 1996. Contaminated sludge was removed from aging septic tanks and placed in waste drums. The drums are currently kept in monitored compliant storage awaiting shipment for offsite treatment.

Waste Area Group 5 Comprehensive RI/FS. This investigation began in February 1995. Waste Area Group 5 has 13 operable units and 54 potential release sites. Activities for 1997 included finalization of the work plan for the comprehensive RI/FS, as well as sampling and analysis to support the remedial investigation and the baseline risk assessment. Activities planned for 1998 include completion of the remedial investigation and the baseline risk assessment and the feasibility study.

\section{Waste Area Group 6-Boiling Water Reactor Experiment}

\section{Boiling Water Reactor Experiment I.}

Remediation of this reactor burial site is discussed under Waste Area Group 5 with the SL-1 burial ground discussion.

Waste Area Group 6 Comprehensive RI/FS. The comprehensive investigation for Waste Area Group 6 is being conducted in combination with the Waste Area Group 10 comprehensive RI/FS.

\section{Waste Area Group 7-Radioactive Waste Management Complex (RWMC)}

Remedial Action of Organic Contamination in the Vadose Zone. The Record of Decision signed by DOE, EPA and the state of Idaho agreeing to use the vapor vacuum extraction with treatment as the remediation technology for the vadose zone at RWMC became final on December 2,1994 . The vadose zone is the area between the land surface and the top of the water table into which organic vapors were released when buried drums containing volatile organic compounds, such as degreasers and solvents, deteriorated over time. The three agencies agreed to take action because small quantities of the contaminants had already reached the Snake River Plain Aquifer.

The full-scale extraction/treatment system consists of three treatment units that extract vapors from three wells. Extracted vapors are then treated using a technology called "Recuperative Flameless Thermal Oxidation." When the vapors reach the optimum oxidation temperature inside the treatment units, the majority of organic compounds break down chemically to form carbon dioxide, hydrogen chloride and water. As of July 1998 , approximately 20,470 kilograms $(45,000 \mathrm{lbs})$ of total volatile organic compounds have been removed from the vadose zone. Phase 2 of this remediation started in January 1998 and will continue to extract and treat organics from the subsurface disposal area for the next two years.

Pit 9 Interim Action. On June 1, 1998, the INEEL management and operating contractor (LMITCO) terminated the Pit 9 Lockheed Martin Advanced Environmental Systems (LMAES) subcontract for default. Therefore, on June 18, 1998, DOE notified EPA and the state of Idaho of its decision to pursue a contingency path, referred to as the Staged Interim Action project, described below. The OU7-10, Staged Interim Action will remediate Pit 9 in accordance with the Record of Decision (ROD) (i.e., physical separation chemical extraction/stabilization).

This contingency path became necessary when the original subcontractor failed to perform its obligations under the subcontract in a timely manner. DOE did not meet two enforceable regulatory milestones, and in March 1997, the 
Agencies developed an Agreement to Resolve Disputes [Reference 3-1].

The DOE remains committed to executing the terms of the Pit 9 Record of Decision. As a result of the Agreement to Resolve Disputes, DOE developed a revised Remedial Design/Remedial Action Scope of Work and Remedial Design Work Plan [Reference 3-2]. The revised Work Plan included a new schedule for implementation of the Pit 9 ROD by the subcontractor, and a schedule for a contingent path, which would be implemented in the event the subcontractor failed to perform their subcontract. The DOE-ID, the EPA and the IDHW jointly developed this contingency plan. The Agencies agreed to proceed with the contingency planning in order to ensure future schedules would be met. In addition, there was a need to obtain information to support the Waste Area Group 7 decision process, including characterization and treatability information.

The primary objective of the Pit 9 Interim Action is to remediate contamination to a level which protects human health and the environment. The Pit 9 Interim Action is also to provide information to support the final remedial decision for the Radioactive Waste Management Complex (RWMC) Subsurface Disposal Area (SDA). In particular, the Pit 9 project was to generate information to support the RI/FS for the RWMC SDA.

The RWMC SDA is under investigation as required by the INEEL FFA/CO. Pit 9 is designated OU 7-10 and is scheduled as an interim action in the FFA/CO action plan. DOE is implementing its obligations under the FFA/CO, as well as other applicable state and federal laws (e.g. CERCLA), through the ROD.

The Staged Interim Action, a three-stage approach agreed to by the agencies, will satisfy the requirements of the ROD. The Staged Interim Action, as the original subcontractor's approach, will result in the remediation of Pit 9 . The Staged Interim Action, like the original Pit 9 approach, is also designed to generate information to support the Remedial Investigation and Feasibility Study for the RWMC SDA.

The Stage I activities will provide early information on specific subsurface conditions, including whether, how far, and which contami-nants have migrated. This information is neces.sary to support the transport modeling and baseline risk assessment activities under WAG 7.

Stage I will also include a limited treatment technology evaluation. Stage II activities include construction, retrieval, and soil treatment studies, and retrieval of buried material from an area of the pit selected during Stage I. Stage II will also obtain further characterization and treatment information to support the WAG 7 decision. Stage III will complete the remediation of Pit 9

Waste Area Group 7 Comprehensive RI/FS. An addendum to the work plan which details how the Comprehensive Investigation will be performed will be completed in August 1998. The addendum will reflect schedule and scope changes that resulted from significant delays in the Pit 9 interim action. These changes will allow DOE to evaluate a wider range of remedial alternatives for the buried waste.

\section{Waste Area Group 8-Naval Reactors Facility (NRF)}

Naval Reactors Facility Remediation. The DOE, EPA, and state of Idaho signed a Record of Decision for 10 sites at the Naval Reactors Facility (NRF) in 1994. Three of these sites were landfills which have been capped with a native soil cover. The agencies agreed the other sites (the industrial waste ditch and six other landfills) required no further action.

Waste Area Group 8 Comprehensive RI/FS. DOE-Naval Reactors, EPA, and the state of Idaho completed the Comprehensive RI/FS for the NRF Waste Area Group (WAG) 8 in September 1997. The RI/FS identified nine inactive waste sites with potential unacceptable risk to human health or the environment. The agencies 
recommended Limited Excavation Disposal, and Containment as the preferred remedy for the nine sites of concern. The Waste Area Group 8 Proposed Plan was issued for public comment in January 1998. The Agencies hosted public meetings in January, 1998 and plan to issue a Record of Decision in September 1998.

\section{Waste Area Group 9-Argonne National Laboratory-West (ANL-W)}

\section{Waste Area Group 9 Comprehensive} RI/FS. DOE, EPA, and the state of Idaho completed the Comprehensive RI/FS for Argonne National Laboratory -West (Waste Area Group 9) in December 1997. Of 39 inactive waste sites considered in the RI/FS, five sites were determined to pose a potential unacceptable risk to human health or the environment. The $\mathrm{DOE} / \mathrm{EPA} /$ state of Idaho preferred remedy for these sites is phytoremediation, which is the use of selected plants to extract shallow depth contaminants from ditch and pond bottoms at Waste Area Group 9. Contaminants of concern include cesium-137 and various nonradioactive heavy metals. The Waste Area Group 9 Proposed Plan was sent out for public comment on January 12 , 1998. Public meetings were held in three Idaho cities during January 20-22, 1998.

\section{Waste Area Group 10-Miscellaneous Sites/Snake River Plain Aquifer}

Unexploded Ordnance Projects. Prior to the inception of the INEEL in 1949, the U.S. Navy conducted aerial bombing practice, naval artillery testing, explosives storage bunker testing, and ordnance disposal at the site. These naval activities resulted in the unexploded ordnance areas that are being addressed in this removal action. Ordnance found to date include artillery shells, partially exploded bombs, anti-tank mines, anti-personnel mines, depth charges, smokeless powder, and dummy bombs with spotting charges. Unexploded ordnance and explosive residues from four areas of the INEEL are being removed in a $\$ 3$ million, time-critical removal action.
An interim action on six ordnance sites was performed in 1993. The six sites included the Central Facilities Area Gravel Pit, the Explosive Storage Bunkers north of INTEC, the National Oceanic and Atmospheric Administration Grid, the CFA-633 Area, the Fire Station II Area, and the Power Line Road. During the interim action unexploded ordnance and ordnance explosive waste were removed to a depth of $0.6 \mathrm{~m}$ (2 feet) at each site, and soils greater than $44 \mathrm{ppm}$ for trinitrotoluene (TNT) and greater than $18 \mathrm{ppm}$ for cyclotrimethylene trinitroamine were remediated. Approximately $140 \mathrm{~m}^{3}\left(185 \mathrm{yd}^{3}\right)$ of explosive contaminated soil were excavated and sent offsite for incineration.

CERCLA removal actions were performed in 1994, 1995, 1996, and 1997. During these actions, unexploded ordnance and pieces of explosives were removed from the Naval Ordnance Disposal Area, the Twin Buttes Bombing Range, an area located east of Lincoln Boulevard at Milepost 17, the Rail Car Explosion Area and the adjacent river bed, the Land Mine Fuse Burn Area, the unexploded ordnance site east of Test Reactor Area, the Mass Detonation Area, the NOAA Grid, the Experimental Field Station, the Fire Station II area, and the craters east of INTEC.

Remaining ordnance removal and soil remediation 69 hectares (170 acres) are planned to be conducted after the OU 10-04 Record of Decision during the Remedial Design/Remedial Action phase scheduled to begin in the year 2003. All ordinance contamination is planned to be complete to meet the objectives of DOE's 2006 Plan [Reference 3-3].

\section{Radionuclide-Contaminated Soils Removal} Action. On May 4, 1995, DOE, EPA Region 10 , and the Idaho Department of Health and Welfare determined that seven of the Waste Area Group 10 radionuclide-contaminated soil sites were to be remediated through removal actions. Excavation at one of the seven locations near TAN showed that contamination was widespread in several areas and could not be completely 
remediated through this soil removal action. Further assessment of that contamination is being conducted, and it may be appropriate to address this problem in the final TAN comprehensive RI/FS. The excavated areas were recontoured and reseeded.

Waste Area Group 10 Comprehensive RI/FS. The comprehensive RI/FS is ongoing and will address the remaining WAG $6 \& 10$ sites, the Snake Plain River Aquifer as well as conducting the site wide ecological risk assessment.

\subsection{WASTE MANAGEMENT PROGRAM INFORMATION}

\section{General Information}

The mission of the Waste Management Program at the INEEL is to provide safe, compliant and cost-effective management services for waste streams and spent nuclear fuel. Safe operations and compliance with federal, state, and local regulations are the highest priorities along with meeting the commitment made in the Settlement Agreement and the INEEL Site Treatment Plan. The goals of the program are to ensure that workers and the public are protected, and that the environment is not further impacted. INEEL waste management activities consist of:

- Reducing the total amount of wastes generated;

- Treating wastes already generated by reducing their toxicity, mobility, and volume;

- Storing wastes awaiting development of new disposal and treatment options; and

- Disposing of wastes.

Another challenge faced in managing wastes at the INEEL is involving the citizens of Idaho in the search for solutions to significant waste management issues. A variety of methods are used to keep the public informed about INEEL activities and involved in making decisions. Some of these are discussed in Section 3.4.

\section{Accomplishments of the Waste Management Program}

The Federal Facility Compliance Act. This act requires the preparation of site treatment plans for the cleanup of mixed wastes, those containing both radioactive and nonradioactive hazardous materials, at the INEEL. The INEEL Proposed. Site Treatment Plan was submitted to the state of Idaho and EPA on March 31, 1995. Copies of the plan were also sent to various reading rooms throughout Idaho, the INEEL Citizens Advisory Board, and the Shoshone-Bannock Tribes. This plan outlined DOE-ID's proposed treatment strategy for INEEL mixed waste streams and provided a preliminary analysis of potential offsite mixed low-level waste treatment capabilities.

The final INEEL Site Treatment Plan formed the basis for state of Idaho and DOE consent order negotiations for mixed waste treatment at the INEEL. The Federal Facility Compliance Act Consent Order and Site Treatment Plan was finalized and signed by the state of Idaho on November 1, 1995. Two changes to the administrative sections of the plan were negotiated to resolve issues between the state and DOE-ID: DOE reserved its right to challenge the approval authority of the state over offsite wastes, and both parties agreed to immediately modify the plan's schedules to be consistent with the Idaho Settlement Agreement and court order issued in October 1995 in the Spent Nuclear Fuel and INEEL Environmental Impact Statement litigation.

In accordance with the INEEL Site Treatment Plan, the INEEL began receiving offsite mixed waste for treatment in January 1996. The shipments of offsite mixed waste were the result of two Department of Defense naval base closures: the Mare Island Naval Shipyard and the Charleston Naval Shipyard. The INEEL has received mixed waste shipments from other sites 
within the DOE complex including Los Alamos, Sandia National Laboratory, Pantex, Paducah, and six locations managed by the Office of Naval Reactors.

Storage and treatment of the majority of the offsite waste will be performed at the Waste Reduction Operations Complex using technologies of incineration, macroencapsulation, stabilization, neutralization, and carbon absorption. Additional offsite mixed wastes will be treated at the Advanced Mixed Waste Treatment Facility planned for construction at the INEEL.

\section{Advanced Mixed Waste Treatment Project.} The overall goal for the project is the treatment of alpha low-level mixed and transuranic waste for final disposal by a process which minimizes overall costs while ensuring safety. This will be accomplished through a private sector treatment facility with the capability to treat specified INEEL waste streams, and with flexibility to treat other INEEL and DOE regional and national waste streams. The services will treat waste to meet the most current requirements, reduce waste volume and life-cycle cost to DOE, and perform tasks in a safe, environmentally compliant manner.

A contract for treatment services was awarded to BNFL, Inc in December 1996. The contract was awarded in three phases. Phase I, licensing, permitting and environmental compliance, is expected to be completed in May 1999. Phase II is construction and process demonstration which is to be completed in December 2002. Phase III, treatment operations, is to begin by March 2003 . The facility will operate until 2015 with the possibility of continued operations until 2033.

\section{High-level Waste (HLW) Treatment and Facilities Disposition. HLW results from repro- cessing spent nuclear fuel and is highly radioac- tive. HLW includes liquid waste produced directly from reprocessing and any solid waste (calcine) derived from the liquid. At the INEEL, HLW exists in both liquid and solid forms and is}

stored in underground tanks and in bins at the INTEC on the INEEL. The INEEL has continued to calcine the liquid non-sodium HLW; completion is planned for 1998. The sodium-bearing liquid radioactive waste is also contained in underground tanks, and the 1995 Settlement Agreement calls for the calcining of this waste by the end of the year 2012. The waste and the amount to be treated are characterized in the Spent Nuclear Fuel \& INEL Environmental Impact Statement (EIS). For more information on the EIS, see section 2.1.

Plutonium Focus Area (PFA). In May 1994, the Defense Nuclear Facilities Safety Board issued Recommendation 94-1 expressing concern that the halt in weapons production froze the manufacturing pipeline, leaving it in a state that "...for safety reasons, should not be allowed to persist unremediated." In the recommendation, the board expressed concern about certain liquids and solids containing unstable fissile materials and other radioactive substances stating "...imminent hazards could arise within two to three years unless certain problems are corrected." In response to board concerns, PFA was chartered (October 1995) to implement the 94-1 Research and Development Plan-identifying, developing, and deploying technologies for the stabilization, characterization, packaging, transportation, and interim storage of plutonium residues.

PFA is a multi-year (i.e., 1995-2002), complex-wide project that includes collaboration on technology ventures with Russian scientists as part of the U.S.-Russian non-proliferation program. PFA research and development projects for 1997 include:

- Development of 3,013 containers from radioactively contaminated scrap metal;

- Advanced plutonium stabilization technology development;

- Demonstration of integrated plutonium monitoring and surveillance system; 
- Development of cold ceramification process;

- Development of plutonium packaging and transportation systems;

- Development of a plutonium stabilization verification system;

- Collaboration on Russian stabilization technologies; and

- Continuation of complex-wide integration functions.

\section{Mixed Waste Focus Area. DOE-HQ} announced in December 1994 that the INEEL had been selected as the lead laboratory for mixed waste technology development. DOE-ID, supported by LMITCO, formed a group called the Mixed Waste Focus Area to coordinate the national effort to treat mixed waste. At the INEEL alone, there is enough mixed waste to fill about 600 railroad boxcars.

In 1997, the Integrated Technical Baseline, which evaluated the characterization and treatment alternatives for all the mixed waste on the Mixed Waste Inventory Report, was updated to reflect new changes from the previous year. Technology deficiencies which prevent a treatment system from being implemented were identified and re-prioritized, and became the principal emphasis of the focus area. Twenty-four deficiencies for the implementation of thermal and non-thermal treatment systems were identified, reduced by four from 1996.

A comparative demonstration of mobile non-destructive assay systems was conducted at the INEEL, using standard and real waste drums. Several ash and salt stabilization technologies were demonstrated at small scale. A demonstration of stabilization of Fernald silo waste was initiated with four stabilization technologies. The Transportable Vitrification System (TVS) completed a mixed waste demonstration at the Oak Ridge K-25 site. $7,300 \mathrm{~kg}(16,000 \mathrm{lbs})$ of pond sludge were treated by the TVS
DOE Accreditation Programs. The Radiological and Environmental Sciences Laboratory (RESL) at the INEEL is the national lead laboratory for two major laboratory accreditation programs. The DOE Laboratory Accreditation Program for personnel dosimetry has operated since 1986. The radio bioassay portion of that program was implemented in 1997 at RESL, and the draft handbook for the DOE Laboratory Accreditation Program for Radiobioassay has been distributed.

The second program is the Mixed Analyte Performance Evaluation Program. The program distributes samples containing known quantities of specific analytes to participating laboratories for analyses. This year, participation grew to approximately 100 laboratories, almost $25 \%$ of: which are foreign.

\section{Low-level Waste Management Program.} Volume reduction treatments at the WERF and direct disposal at the RWMC Subsurface Disposal Area (SDA) disposed of approximately $1,400 \mathrm{~m}^{3}\left(1,830 \mathrm{yd}^{3}\right)$ of low-level radioactive waste (LLW). Prior to 1997, the INEEL had approximately $16,800 \mathrm{~m}^{3}\left(22,000 \mathrm{yd}^{3}\right)$ of LLW in storage awaiting disposal. In $1997,4,300 \mathrm{~m}^{3}$ $\left(5,620 \mathrm{yd}^{3}\right)$ of LLW was treated at WERF to reduce the volume to be disposed of at the SDA. This treatment, along with direct disposal of LLW, resulted in the disposal of approximately $1,400 \mathrm{~m}^{3}\left(1830 \mathrm{yd}^{3}\right)$ of LLW. Current plans call for using the SDA for on-site disposal of LLW through 2006 for ContactHandled LLW and 2008 for Remote-Handled LLW. Future disposal of INEEL generated LLW is being evaluated by DOE and stakeholders.

\section{Waste Minimization/Pollution Prevention}

The mission of the INEEL Pollution Prevention Program is to reduce the generation and release of wastes and pollutants by implementing cost-effective pollution prevention techniques, practices, and policies. Pollution prevention is also required by various Orders, including but not limited to, the Pollution Prevention Act of 
1990 , the Resource Conservation and Recovery Act, Executive Order-12856 Federal compliance with Right-to-Know Laws and Pollution Prevention, and Executive Order 12873-"Federal Acquisition, Recycling, and Waste Prevention."

It is the policy of DOE-ID and LMITCO to incorporate pollution prevention into every INEEL activity. Pollution prevention is one of the key underpinnings of the INEEL Environmental Management System. It functions as an important preventive mechanism in that reduced waste generation reduces waste management costs, compliance vulnerabilities, and the potential for environmental insult. The INEEL is promoting the inclusion of pollution prevention into all planning activities as well as the concept that pollution prevention is integral to mission accomplishment.

Noteworthy pollution prevention accomplishments in 1997 include:

- 53 metric tons of radioactive contaminated lead was used as shielding in the manufacture of containers for remote-handled mixed transuranic waste. This project has been nominated for a DOE National Pollution Prevention Award.

- The INEEL Decontamination and Decommissioning Program recycled 595 metric tons of recovered scrap iron and 28.3 metric tons of stainless steel.

- Approximately 1,875 fluorescent light tubes containing mercury were replaced by nonhazardous tubes for a waste disposal cost avoidance of $\$ 84,000$. All light tubes procured in the future will be non-hazardous, thereby eliminating an NEEL hazardous waste stream.

- The INEEL Pollution Prevention Unit purchased launderable anti-contamination clothing with the goal of eliminating a routine low-level waste stream comprised of disposable clothing. $\$ 38,700$ was saved this year with expectations for increased savings in future years with expanded use of the launderable product.

\section{Recycling and Re-use of Excess Materials}

In November 1996, the cold waste cuber was brought on-line and began converting the nonradioactive cold waste at the INTEC into fuel for the INEEL Coal Fired Steam Generation Facility. This translates to $80 \%$ of the INTEC office waste going to the cuber, and ultimately to fuel, rather than the landfill. Beginning January 21, 1997, all INEEL cold combustible waste began being diverted from the landfill to the cuber. During December 1997, 2,113 $\mathrm{m}^{3}$ (2,672 $\mathrm{yd}^{3}$ ) of waste was received at the facility, producing $4,770 \mathrm{~kg}(10,500 \mathrm{lbs})$ of cubes. Production rates will increase as experience is gained in operation of the system. Current projects show that disposal of INEEL non-radioactive waste to the landfill could be reduced by $65 \%$, with a corresponding reduction in disposal costs. This project has generated interest worldwide and numerous tours are conducted on an almost weekly basis with visitors from the United States and foreign countries. The cuber has also turned out to be a cost-effective method of handling the INEEL's sensitive, unclassified paper, resulting in a significant cost savings in the handling of that material. In addition to the cost savings, the mixture of coal and cubes burns cleaner and more efficiently than the present fuel. Burning cubes at the Coal Fired Steam Generation Facility will reduce sulfur and nitrogen oxide emissions and heavy metal releases.

The fuel is now being tested with a bio-oil additive (processed from organic matter) that increases heat content and decreases pollutant emissions. This technology has great promise to eliminate the landfill disposal of $75 \%$ of INEELgenerated sanitary waste, and provide an environmentally preferable alternative fuel. 
Lead Management Program. The intent of the INEEL Lead Management Program is to minimize new lead purchases, evaluate lead substitutes, maximize reuse of contaminated lead for shielding, protect lead from contamination, reduce the accumulation of contaminated lead, recycle contaminated lead to the scrap metal ${ }^{\text {' }}$ market by decontamination and surface and volumetric survey for free release, and provide the means for generators to disposition mixed waste lead.

The dismantlement of lead casks and devices continued in 1997. Five large casks and five TX4 boxes with small lead shielded cases were processed by cask dismantlement. The total weight of the casks and devices dismantled in 1997 was $118,730 \mathrm{~kg}(261,200 \mathrm{lbs})$. The volume of mixed waste processed by cask dismantlement was $61.02 \mathrm{~m}^{3}\left(79.7 \mathrm{yd}^{3}\right)$ and the total weight of clean lead recovered for recycle was $23,820 \mathrm{~kg}$ $(52,400 \mathrm{lbs})$.

The Site Treatment Plan backlog schedule for treatment of mixed waste lead-shielded casks was established in January 1996. The backlog schedule identified $136.7 \mathrm{~m}^{3}\left(179 \mathrm{yd}^{3}\right)$ of waste lead and lead-shielded casks. In FY-1996, 9.27 $\mathrm{m}^{3}\left(12.1 \mathrm{yd}^{3}\right)$ of this waste were processed by the cask dismantlement activity. In FY 1997, an additional $61 \mathrm{~m}^{3}\left(80 \mathrm{yd}^{3}\right)$ of casks were dismantled. The combined percentage of the backlog processed as of September 1997 was $51.4 \%$. Therefore, the established milestones to process $25 \%$ of the backlog by March 31,1998 , and to process $50 \%$ by March 31, 1999, have both been completed ahead of schedule.

A total of $94,406 \mathrm{~kg}(207,693 \mathrm{lbs})$ of clean lead recovered from past cask dismantlement activities were recycled to the private sector during the 1997 calendar year. A total of $109,000 \mathrm{~kg}(240,000 \mathrm{lbs})$ of mixed waste lead was shipped off-site for treatment and disposal during 1997.

\section{Alternative-fueled Vehicle Program}

INEEL alternate-fueled vehicle (AFV) program efforts expanded in 1997. The six liquefied natural gas (LNG) powered buses have continued to perform well. This cooperative effort between the INEEL and industry has been highly successful in proving the technology both from operational and emissions performance standpoints. Operational testing has proven the LNG engine's ability to compete with existing fossil engines, and at the present the 1,450-plus-km (900-mile) range of two of the buses is a competitive advantage. The program has resulted in international as well as national attention, as evidenced by visits from British Gas, Tokyo Gas, and several Canadian companies and requests to exhibit the INEEL LNG buses at a number of events. In 1996, the LNG buses were well received at the Olympics in Atlanta, and, in 1997, the LNG buses were favorably received at the G-8 Summit in Denver, at the Olympic Committee meeting in Salt Lake City, and in several other showings. In addition to excellent emissions performance, maintenance requirements have been observed to be lower than those of conventional vehicles. The buses have accumulated approximately $370,000 \mathrm{~km}(230,000$ miles $)$ without any mechanical failures related to natural gas.

The INEEL fleet operations continue to meet the regulations of the Clean Air Act and Executive Orders, specifically in fossil fuel emissions reduction requirements and $A F V$ acquisition goals. In 1997, the fleet comprised of the six LNG buses and 87 AFV light-duty vehicles (LNG, CNG, LPG). Acquisitions and conversions in 1998 will increase the numbers of AFVs, both buses and light duty vehicles. Also during 1998, a second natural gas fueling station will be commissioned into service. The INEEL is performing research and development on a low-cost liquefaction fueling station to help overcome the scarcity of refueling stations. After prototype testing at the INEEL additional stations will be installed in the Salt Lake City area in support of the 2002 Olympics. 


\section{Waste Treatment Accomplishments}

Offsite Mixed Low-Level Waste Treatment. The INEEL is marketing the capacity to treat DOE mixed low-level waste by incineration at the Waste Experimental Reduction Facility (WERF). Under provisions proposed in the NEEL Site Treatment Plan, any offsite waste received at the INEEL must be treated within six months of receipt, and all treatment residues sent out of Idaho within six months of treatment.

In June 1996, the INEEL received 51 drums containing approximately $10,000 \mathrm{~L}(2,640$ gallons) of mixed low-level waste from the Los Alamos National Laboratory. The shipment tested the system for receipt of offsite waste to see if the established time frames could be met. Six drums of ash, treatment residues from the incineration of the mixed low-level waste, were shipped to Envirocare in Utah for permanent disposal in March 1997. All time frames were met.

Since this first offsite waste treatment campaign, a second shipment of mixed low-level waste, $26 \mathrm{~m}^{3}\left(34 \mathrm{yd}^{3}\right)$, has been received and incinerated from the Los Alamos National Laboratory. Waste shipments totaling $44 \mathrm{~m}^{3}\left(58 \mathrm{yd}^{3}\right)$ have been received and incinerated from the Naval Nuclear Propulsion Program. This amount includes waste shipments from Mare Island Naval Shipyard, Charleston Naval Shipyard, Puget Sound Naval Shipyard, Pearl Harbor Naval Shipyard, Norfolk Naval Shipyard, Bettis Atomic. Power Laboratory, and Knolls Atomic Power Laboratory. Waste shipments from the Pantex Plant in Amarillo, Texas, the Sandia National Laboratory in Albuquerque, New Mexico, and the Paducah Gaseous Diffusion Plant in Kentucky are scheduled for the first part of Calendar Year 1998.

WERF Waste Processes Program. The Waste Reduction Operations Complex (WROC) processed Mixed Low-Level Waste/Low-Level Waste (MLLW/LLW) throughout 1997. The WERF Incinerator processed $103.6 \mathrm{~m}^{3}$ $\left(135.4 \mathrm{yd}^{3}\right)$ of MLLW and $1,276.8 \mathrm{~m}^{3}$ $\left(1,668.7 \mathrm{yd}^{3}\right)$ of LLW. In addition to the incineration of MLLW/LLW, LLW volume reduction was performed: $2,318.1 \mathrm{~m}^{3}\left(3,030 \mathrm{yd}^{3}\right)$ of LLW was compacted and $793.3 \mathrm{~m}^{3}\left(1,037 \mathrm{yd}^{3}\right)$ was sized; 866 shifts of waste processing were performed in 1997.

\section{Waste Storage Accomplishments}

Dry Fuel Storage Agreement. DOE-ID presented its case to the state of Idaho for storage of certain CPP-603 fuels in the Irradiated Fuel Storage Facility. However, the state did not agree that the facility was adequate for safe storage, expressing concern about seismic vulnerabilities of the facility. Further seismic analysis was performed in preparation for proposed modifications to the facility west wall. The analysis demonstrated that the facility seismic deficiencies could be eliminated. Modifications to the facility west wall were completed in December 1997. On January 7, 1998, the state agreed that, with the seismic upgrades to the facility, the facility was now adequate for storage of the CPP-603 fuels and provided their authorization for such storage. DOE-ID began transfer of CPP-603 fuels on February 7, 1998. A separate agreement to allow transfer of the fuels while facility upgrades were in progress was no longer required and was not executed.

The Idaho Settlement Agreement. On October 16, 1995, DOE, the United States Navy, and the state of Idaho entered into an agreement which will guide management of spent nuclear fuel and radioactive waste at the INEEL for the next 40 years. The agreement makes Idaho the only state with a federal court-ordered agreement limiting shipments of DOE and Naval spent nuclear fuel into the state and setting milestones for shipments of spent nuclear fuel and radioactive waste out of the state

During 1997, DOE lowered the risk of potential releases to the Snake River Plain Aquifer by reducing the total volume of liquid high-level waste stored in underground tanks at the INEEL. 
Operation of the High-Level Liquid Waste Evaporator in early 1997 reduced liquid inventory by over $1,249,000 \mathrm{~L}$ ( 330,000 gallons). In June, DOE began converting the concentrated liquid waste into a granular, more stable form called calcine with the restart of the New Waste Calcining Facility after a three-year shutdown.

DOE and BNFL, Inc. met state licensing requirements for siting a new hazardous mixed waste treatment facility on the INEEL. This was the first of several steps for the Advanced Mixed Waste Treatment Project, a facility for trcating clothing, equipment, tools and sludge, contaminated with radionuclides such as plutonium, and hazardous chemicals. The facility will destroy the hazardous constituents, reduce the volume, and prepare the waste for disposal at the Waste Isolation Pilot Plant in New Mexico. This facility is currently slated to incinerate and vitrify $22 \%$ of waste and supercompact and/or macroencapsulate the remainder of the waste. The facility will also be designed to meet the technical requirements of Idaho's Hazardous Waste Management Act and the Clean Air Act.

Because of poor conditions in aging facilities, DOE is aggressively moving spent nuclear fuel into safer interim storage at the INEEL. DOE applied for a license with the Nuclear Regulatory Commission for a new dry, aboveground storage facility to house the damaged Three Mile Island reactor core and spent fuel, currently stored in a deteriorating water basin. DOE is also continuing to transfer other spent fuel from aging basins into more modern facilities.

As an alternative to wet storage of its spent nuclcar fuel, the Navy is designing and manufacturing containers for dry storage and eventual transport out of Idaho. The Navy also began design and contractual preparations for the facility to load fuel into these containers.

As part of the settlement agreement, Idaho received its sccond installment of \$6 million from DOE for cconomic development in castern Idaho.
Idaho awarded grants to the Regional Development Alliance and state universities and colleges to reduce economic dependence on the INEEL. Awards to date are projected to create over 1,500 jobs. In northern Idaho, the Navy met a settlement agreement commitment by beginning a $\$ 7$ million expansion project at its Acoustic Research Detachment on Lake Pend Oreille.

\section{Waste Disposal Accomplishments}

Although it is DOE's goal to eliminate the generation of wastes, ongoing operations result in the creation of waste ultimately requiring disposal, and in some cases, permanent isolation from people and the environment. Currently, only industrial and low-level radioactive wastes are being disposed of at the INEEL. Other waste types are being stored for eventual disposal at the Site and elsewhere or until treatment technologies are available.

Low-Level Radioactive Waste. As mentioned above, in 1997 the INEEL reduced its inventory of approximately $16,800 \mathrm{~m}^{3}\left(22,000 \mathrm{yd}^{3}\right)$ of stored Low-Level Radioactive Waste by a total of approximately $4,800 \mathrm{~m}^{3}\left(6,270 \mathrm{yd}^{3}\right)$ through volume reduction and direct disposal in the RWMC Subsurface Disposal Area.

Transuranic Waste. The consent order milestone to reconfigure accessibly stored TRU waste was completed July 1997, four months ahead of schedule.

The TRU Waste Characterization Program will ensure TRU waste is properly characterized to meet the Waste Isolation Pilot Plant (WIPP) wastc acceptance criteria. Every major subsystem in the Stored Waste Examination Pilot Plant was modified in order to meet production throughput requirements. Non-intrusive characterization at the RWMC commenced productionrate operations in September 1997. The concept for a container/data management system called the Transuranic Reporting Inventory and Proecssing System is currently in development in 
order to handle the critical volume of data requirements identified by WIPP.

Efforts in support of the Matrix Depletion Program continued to provide scientific evidence to support the reduction of WIPP Waste Acceptance Criteria transportation requirements. The INEEL continued to assist in the execution of the Performance Demonstration Program, which certifies that equipment across the complex is operating satisfactorily and provides assurances to the regulators of WIPP that waste is being properly characterized.

The TRU project continued to support efforts to examine the effectiveness of waste inspection tomography and the active and passive neutron examination and assay systems. This is a joint venture between DOE, academia and private industry to improve characterization of TRU waste.

\section{Waste-related Research and Development}

A wide variety of research projects are conducted at the INEEL to benefit major DOE-ID programs. The Environmental Science and Research Foundation and its university affiliates primarily conduct ecological and radioecological research. LMITCO conducts a wide range of projects including methods of waste characterization and disposal, robotics, alternate-fuel vehicles, and bioremediation of wastes.

\section{Environmental Science and Research}

Foundation Program. The Environmental Science and Research Foundation, an independent nonprofit organization, conducts a variety of waste-related research for DOE-ID on the INEEL. Much of this work is performed through a network of university affiliates from local and regional academic institutions working with the Foundation.

The Protective Cap/Biobarrier Experiment was designed to rigorously test the performance of four protective cap configurations for lowlevel buried wastes in semi-arid to arid climates.
In order to effectively store wastes underground, it is necessary to keep water out of the waste material.

The ultimate objective of the experiment is to confidently recommend an effective, economical soil-plant cover system for interred wastes at the NNEEL and climatically similar repositories. During the first three years, baseline data were collected on plant establishment, rooting depths, patterns of soil water storage and depletion. Burrowing ants were introduced to the plots in 1996, and burrowing rodents will be introduced in the spring of 1998. Current plans call for application of excess irrigation until cap failure occurs (drainage through the entire cap) in the sixth year. Results from these manipulations will allow the prediction of the amount and seasonal distribution of precipitation that could fall on the site before a particular cap configuration would fail, and whether burrowing organisms will significantly affect cap performance under high levels of precipitation.

Another, related experiment is testing the effectiveness of closure cap materials in preventing the entry of small mammals into closed hazardous waste areas. The intrusion of burrowing mammals into hazardous waste areas and the subsequent transport of waste off the burial area has been shown to be a problem in older waste areas and continues to be a concern regarding future closure of current waste areas. The objective of one study is to determine the effectiveness of three types of material in preventing the burrowing of small mammals into waste areas. The three materials are 5- to $10-\mathrm{cm}$ (1- to 2 -in) cobble, chipped roofing gravel, and a mixture of gravel and cobble. In 1994, Townsend's ground squirrels and Ord's kangaroo rats were introduced into enclosures containing $50-\mathrm{cm}(20-$ in) thick layers of these materials overlaid by native soil. An additional objective was to determine whether creating such a biobarrier in the presence of burrowing mammals might alter soil moisture patterns and compromise the integrity of the waste cap. After three years, there is still 
no evidence that the test animals have burrowed through the biobarrier layers.

Various EPA and DOE regulations require that shallow-land burial sites for mixed low-level radioactive wastes remain effective at least 100 years. Primary to the success of a waste management site is the capability to keep wastes isolated from water. At the INEEL, most of the annual soil moisture recharge results from precipitation during the months when plants are dormant (October - March). Improvements in management practices since 1952 at the RWMC have resulted in differences in soil covers, thickness, land contours, vegetation types, and proximity of buried wastes to roads and ditches. Each of these factors influences soil moisture dynamics in the protective soil caps. Since 1988, the Foundation has measured soil moisture on eight study sites within the RWMC, mostly during the late winter, early summer, and fall Throughout that period, precipitation during the non-growing season ranged from $46.6 \%$ to $135.5 \%$ of normal. Soil moisture recharge was generally less than $40 \mathrm{~cm}$ (16 in) deep for all areas and years except for 1989, 1993, 1995, and 1997. During those years maximum infiltration was recorded at depths of up to $1.4 \mathrm{~m}$ $(4.6 \mathrm{ft})$.

Research is being conducted to determine the fate of radionuclides released as liquid effluent to two double-lined evaporation ponds at TRA. In order to determine the fate of radionuclides at the TRA ponds, it is necessary to quantify all inputs to, and losses from, those systems. Emphasis was placed on determining potential radionuclide transport from the ponds, especially transport to humans via waterfowl which have spent time on the ponds. During 1997, 24 samples were taken to quantify radionuclide concentrations in the pond components and in bird species potentially transporting radionuclides from the ponds. A total of 52 analyses were conducted on those samples. Results from the analysis of waterfowl and mourning doves are presented in Chapter 4, and an evaluation of the potential dose to humans is provided in Chapter 8 .
Summaries of these and other Foundation research projects are published annually [Reference 2.5].

Subsurface Contaminants Focus Area. The Subsurface Contaminants Focus Area is led by DOE's Savannah River Site. The mission is to contain, control, and/or remediate waste site source terms and contaminant plumes to environmentally acceptable levels. The INEEL leads the Source Term Remediation Product Line featuring a suite of technologies related to location, characterization, retrieval, stabilization, and disposal of buried wastes.

The INEEL has been successful in achieving applications, or deployments, of several new technologies at the INEEL and other DOE facil-. ities, including the Savannah River Site and the Mound facility. Partnerships have been formed with other DOE offices, private industry, and universities for development and deployment of these technologies.

Other Subsurface Contaminants Focus Area projects at the INEEL included development of technologies that address remediation of the TAN Injection Well plume, emplacement of subsurface barriers under existing waste pits and stabilization of buried wastes. The INEEL also provides systems engineering and integration services for the focus area and has created the Decision Analysis for Remediation Technology System, an interactive database that includes complex-wide subsurface remediation needs and applicable technologies.

\subsection{ENVIRONMENTAL RISK REDUCTION}

\section{Decontamination \& Dismantlement (D\&D)/Demolition Activities}

D\&D and demolition activities at the INEEL are primarily concerned with the safe and compliant decontamination and disposition of inactive facilities/structures potentially suitable for reuse, and the $\mathrm{D} \& \mathrm{D} /$ demolition, and disposal of those 
inactive facilities/structures not suitable for reuse. 12 facilities/structures were identified for D\&D in FY-97 with 10 more planned for FY-98.

Pollution Prevention. INEEL D\&D projects are required to apply the precepts of pollution prevention and waste minimization. Such applications are accomplished by on-site incineration, compaction, and sizing technologies at the INEEL Waste Experimental Reduction Facility (WERF) prior to their disposal at the INEEL Radioactive Waste Management Complex (RWMC). The reuse and reclamation of equipment and materials resulting from D\&D activities is a major goal of $D \& D$ projects. In $1997, D \& D$ project activities recycled/reused structural steels and component items and brass/ bronze totally approximately 265 tons, 15 tons, and 3 tons respectively.

\section{Activity Summary}

Following are INEEL area-specific summaries of $\mathrm{D} \& \mathrm{D} /$ Demolition projects completed during the year.

Test Reactor Area (TRA). The D\&D and removal of a concrete basin for a cooling tower structure was completed as well as its coolingwater pump house facility including the pumping system. The affected areas were graded to be consistent with the adjoining lands. The cooling tower and pump-house supported the now shutdown Engineering Test Reactor (ETR).

Auxiliary Reactor Area (ARA-I, -II, \& -III. The D\&D and removal of a guardhouse and storage building from the ARA-II and -III sites was completed. Also saw-cut sectioning effected the size-reduction and bulk disposal of approximately $60 \%$ of a heavily reinforced concrete hot-cell at ARA-I. Completion of these D\&D activities is planned for 1998 .

Central Facilities Area (CFA). The D\&D and removal was completed of several facilities that had supported INEEL operations over the past 40 years. The facilities included the "Big Shop" (vehicle/equip, maintenance), a Storage Building, an Ammunitions Bunker, a Lead Shop, a Diesel Fuel Pump-house, and a Tire Warehouse, followed by grading the affected areas consistent with the adjoining lands.

Chemical Processing Plant (CPP). The D\&D project involved the D\&D and in-place entombment of three waste process support facilities inactive since 1985 to 1990 . The $D \& D$ and inplace entombment of two of the facilities was completed with completion of the third in-place entombment planned for 1998.

The facility cleanup and removal of all uraniumbearing materials from the ROVER processing facility was completed, thus eliminating what had been determined to be currently the highest environmental risk on the INEEL. This facility will become part of the planned entombment scheduled to start design efforts in 1998.

\subsection{ADDITIONAL ENVIRONMENTAL PROGRAMS}

\section{Public Involvement in INEEL Program Activities}

INEEL public involvement activities during 1997 included:

- Publishing four INEEL Reporters;

- Publishing two INEEL Reporter Progress Report Supplements;

- Hosting three major public scoping meetings for environmental impact statements;

- Providing more than a dozen briefings to the INEEL Citizens Advisory Board;

- Holding three briefings with the ShoshoneBannock Tribes;

- Hosting 189 tours with a combined attendance of 3,600 people; and 
- Holding two rounds of media briefings on WAGs $1,3,8$ and 9 .

Members of the public may call 1-800-7082680 to request specific documents. These documents are also available on the Internet by typing http://www.inel.gov to call up the INEEL Homepage. The INEEL Reporter is found under "About INEEL."

\section{Public Communication and Education Activities}

To foster public understanding of environmental issues involving the INEEL, concerted communication and education efforts are made by DOE-ID and its contractors. A wide array of tours, speaking engagements, newsletters, shopping mall displays, and opportunities to request INEEL information are made available to interested persons. These efforts provided information directly to about 50,000 people in 1997 . News releases and other contacts with journalists spread INEEL messages to much wider audiences.

Through a toll-free telephone number (800708-2680), anyone can call the INEEL to ask questions and request copies of documents.

LMITCO Public Affairs. Because the LMITCO Public Affairs Department communicates about all INEEL activities, its broad focus includes environmental matters. LMITCO Public Affairs is responsible for INEEL facility tours, the Experimental Breeder Reactor I (EBRI) historic landmark, INEEL news media relations, INEEL's speakers bureau, and a toll-free telephone service for information requests.

Almost 3,600 people toured the INEEL in 189 tours in 1997 . Tours are individually arranged to visit facilities which suit the interests of each group. Most tours include a stop at EBR-I and a viewing of the spent fuel storage pools inside INTEC. EBR-I, a National Historic Landmark where electricity was first produced from atomic energy, is open to walk-in visitors from Memorial Day to Labor Day. Visitors gain not only a historical perspective on the development of nuclear reactors, but also an overview of research at the INEEL and the flora and fauna of the sagebrush steppe.

\section{Environmental Science and Research Foun-} dation's Communications and Education Program. The Environmental Science and Research Foundation, as a DOE-ID contractor for environmental monitoring, ecological research and environmental services on the INEEL, aims to improve public understanding of the INEEL's environment through a public education program. This program employs two community monitoring stations, news releases, presentations, interpretive signs, posters, and displays, Internet presence, a travelers' information radio station, and a newsletter. The content of these communication strategies incorporates a recognition of the INEEL's environmental legacy of radioactive materials, which must be properly managed, along with information about the wealth of Idaho's natural heritage present on the Site. As a much smaller organization than LMITCO, the Foundation's communications and education activities are not as extensive. They do, however, concentrate solely on INEEL environmental matters.

One of the primary responsibilities of the INEEL Offsite Environmental Surveillance Program, conducted by the Foundation, is to communicate environmental data to interested persons. The data, along with easy-to-follow interpretations and explanations of underlying concepts, are incorporated into reports, reports summaries, fact sheets, multimedia presentations, and a portable display. The Foundation's portable display describes the environmental surveillance program, and was made available to libraries and other public institutions throughout Idaho. In 1997 it appeared at 14 locations: Moreland, American Falls, Dubois, Rexburg, Idaho Falls, Pocatello, Ririe, Sun Valley, St. Anthony, Arco, Mackay, Sugar City, Shelley, and Hamer. 
As innovative educational tools for the environmental surveillance program, a pair of community monitoring stations were operated at Madison Middle School in Rexburg and Mountain View Middle School in Blackfoot. These stations monitor radioactivity and particulates in the air, environmental radiation levels, and weather conditions, providing some real-time measurements and collection of samples for laboratory analysis. The stations provide community involvement and educational opportunities, as well as actual environmental surveillance data. Data from the stations, along with other data collected within the surveillance program, are being incorporated into science and mathematics lessons.

The Foundation issued 25 news releases about the INEEL's environment to a mailing list of Idaho news outlets. During 1997, Foundation personnel gave 75 presentations to professional peers, students, civic leaders, and other audiences. Several thousand persons attended Foundation presentations.

During 1997, nine reports were published by the Foundation. Notable among these were Conference Proceedings of "Landfill Capping in the Semi-Arid West: Problems, Perspectives, and Solutions," a publication of papers presented at a successful technology transfer conference hosted by the Foundation in the spring, and the Idaho National Engineering and Environmental Laboratory Site Environmental Report for Calendar Year 1996. In addition to Foundationpublished reports, Foundation researchers had 29 technical, peer-reviewed articles and reports published, in press, or submitted.

The Foundation-operated INEEL travelers information radio station broadcast continuously during 1997. Located at the intersection of U.S. Highways 20 and 26, the low-powered transmitter broadcasts on a frequency of $530 \mathrm{AM}$ and is available to persons in the 800,000 vehicles driving on these highways each year. Fourteen messages discussed the environment, natural history, and cultural history of the NNEEL and the southeastern Idaho desert.

The Foundation Focus newsletter reached a broad audience with stories about research about and monitoring of the INEEL's environment. Circulation was maintained at more than 1,000 in 1997. The first three issues of 1997 were significant in containing an in-depth series of articles entitled "The Site, the Plain, the Aquifer, and the Magic Valley," which analyzed the effects of the INEEL on the aquifer beneath the Snake River Plain.

American Indian Program. DOE- ID is currently focusing on expanding and strengthening the government-to-government relationship with the Shoshone-Bannock Tribes of Fort Hall, Idaho. The Tribes are close neighbors of the INEEL, and are potentially affected by INEEL operations. They have a vested interest in the INEEL as they have inhabited the Snake River valley continuously for the past 10,000 years. DOE-ID has developed an Agreement in Principle with the Tribes that addresses DOE-Indian policy objectives. DOE-ID also funds programs and projects through a cooperative agreement, sponsored by the HQ EM organization, intended to enhance tribal awareness, capabilities, and participation in INEEL activities. The core program addresses environmental management activities including NEPA, transportation, environmental monitoring and training, cultural resources management, and emergency response and management.

DOE also funded the construction of an Emergency Operations Center and a Community Monitoring Station at Fort Hall. The Center is equipped with state-of-the-art communications and tracking equipment and is manned by a fully trained emergency management staff. The Community Monitoring Station provides environmental data to the public and tribal officials for the purposes of outreach, environmental and emergency management. All INEEL air, radiation, and meteorological data collected by the State of Idaho and the NOAA Air Resources 
Laboratory Field Research Division is accessible to the tribes via this system. An educational program is being fostered that will include the Fort Hall schools. This is the only monitoring station of its kind in the DOE system operated by an American Indian tribe. DOE-ID played a key role in determining and ensuring funding, establishing interactions between the tribes, state, and NOAA, and coaching this project through fruition.

\section{INEEL-sponsored Academic Programs}

INEEL and DOE-ID provide paid research and work opportunities for students from Idaho institutions: in 1997, 116 college students, 227 high school students and teachers were involved. The Environmental Science and Research Foundation also supports research programs at 13 universities, primarily in the Intermountain West. A total of 19 faculty and staff, 15 research assistants, 18 graduate students, 49 technicians, and 39 temporary employees were funded through Foundation projects.

For more information on INEEL-sponsored academic programs, visit the INEEL website at: http:/www.inel gov/doeid/academic/index.htm and the Foundation website at htto:/esrf.org.

\subsection{ENVIRONMENTAL MONITORING}

\section{Purpose and Organization of Monitoring Programs}

Routine operation of INEEL facilities releases some materials, which may include both radioactive and nonradioactive contaminants, into the environment. There are two primary routes by which these materials can enter the environment-into the atmosphere as airborne effluents and into surface water and ground water as liquid effluents. Through a variety of exposure pathways (Figure 3-1), contaminants can be transported away from INEEL facilities, where they could potentially impact the surrounding environment and the population living in these areas.
The primary purpose of the various environmental monitoring programs conducted at the INEEL is to evaluate these different exposure pathways, and to determine what effects may be: occurring in the environment. In addition, monitoring provides the information to verify compliance with a variety of applicable environmental protection laws and regulations described in Chapter 2. DOE Order 5400.1 also requires DOE sites to conduct an environmental monitoring program.

The term environmental monitoring is used to describe two separate activities. Effluent monitoring is the measurement of the waste stream prior to its release to the environment, such as the monitoring of stacks or discharge pipes.

Environmental surveillance is the measurement of pollutants in the environment. Surveillance involves determining whether or not pollutants are present or measurable, and if present, in what concentrations they are found.

At the INEEL, environmental monitoring is a collective effort involving a number of different organizations and groups. The remainder of this section provides a summary of the various environmental monitoring activities currently being conducted.

\section{Effluent Monitoring Programs}

Radiological Effluents. Radionuclides in airborne effluents released to the environment were monitored by the contractor responsible for operating each facility. There are currently six airborne emission points for which continuous monitoring for radionuclides is required under the National Emission Standards for Hazardous Air Pollutants. Of these six points, two are at ANL-W, two are at INTEC, and two are at WERF. Other emission points are monitored to verify that they remain below the threshold at which continuous monitoring is required, or for general facility information.

Data from each of these release points are reported monthly to a centralized database, the 


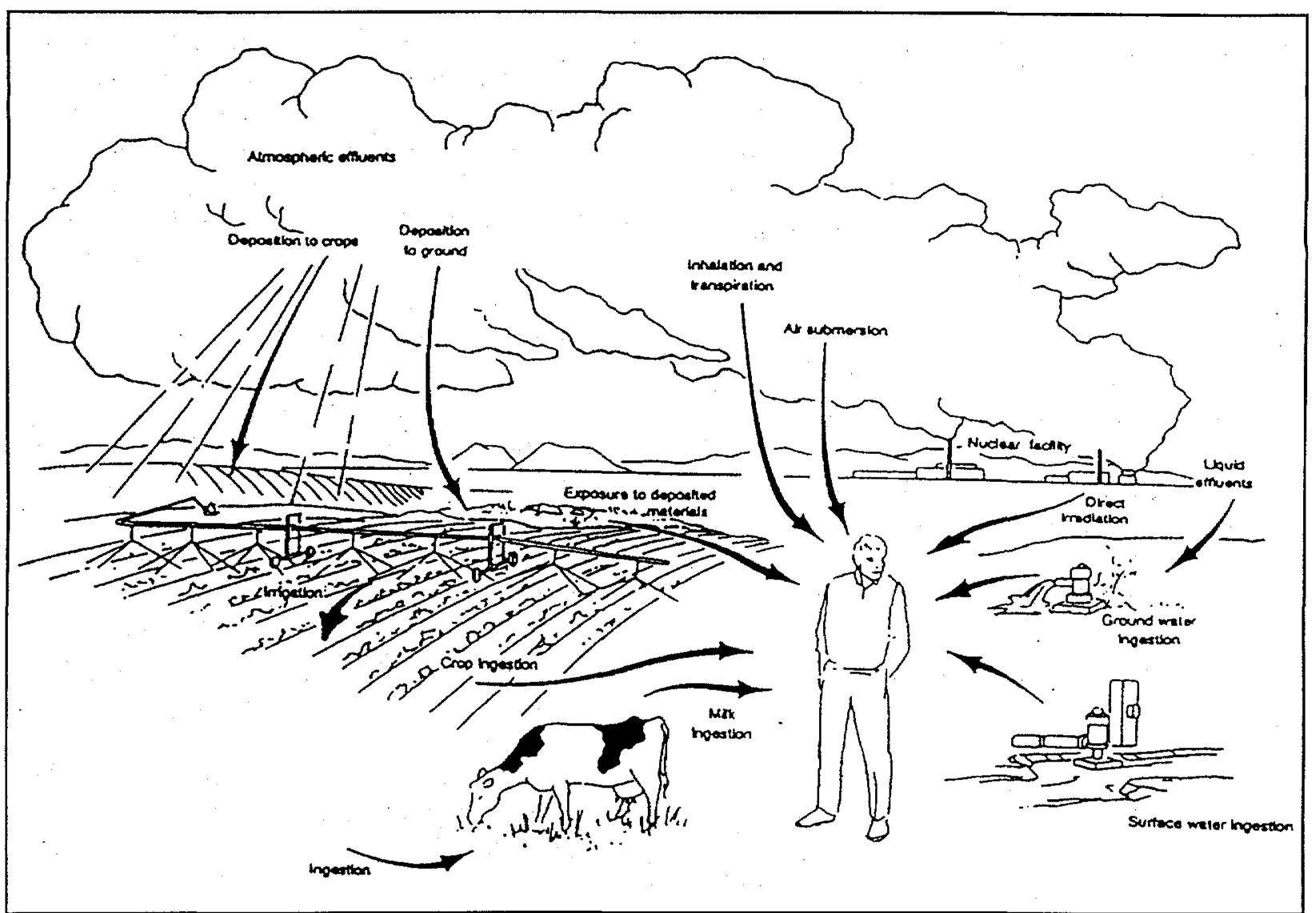

Figure 3-1. Potential Pathways from the INEEL to Humans

Radioactive Waste Management Information System, operated by LMITCO. An annual report of the results of the effluent monitoring organizes the data by month, facility, and radionuclide.

Radioactive liquid effluents are also monitored at release points and compiled in the Radioactive Waste Management Information System. Most liquid radioactive effluents are discharged into lined ponds (or evaporated). No radioactive liquids are released to offsite surface waters, or to streams on the INEEL.

Nonradiological Effluents. Nonradiological airborne effluents originate from the following primary sources at the INEEL:

- Calcination of high-level radioactive liquid waste at the New Waste Calcining Facility;
- Combustion of coal for steam generation at the Coal Fired Steam Generating Facility;

- Combustion of fuel oil used for heating INEEL facilities;

- Combustion of fuel in engines operating generators;

- Motor vehicle exhaust; and

- Fugitive dusts from a number of activities, including construction and waste burial.

Emissions of nitrogen dioxide are routinely monitored at the New Waste Calcining Facility, and sulfur dioxide, nitrogen dioxide, and carbon oxides are monitored at the Coal Fired Steam Generating Facility. Monitoring data for these sources are published in the INEEL Nonradiological Waste Management Information System 
annual reports. Sulfur dioxide emissions from heating oil usage are calculated from the sulfur content and the quantity of fuel used. Emissions of nitrogen dioxide from fuel oil are calculated using EPA emission factors [Reference 3-4] and the amount and type of oil used at each facility. Motor vehicle exhausts and fugitive dusts are not monitored at the source.

At ANL-W, the Experimental Breeder Reactor II auxiliary boilers are monitored monthly, both as an efficiency check and to ensure that emissions of nitrogen oxides and sulfur dioxide remain below the state of Idaho's emission limits. A portable stack emission monitor provides a direct printout of ambient and stack temperature, carbon monoxide, carbon dioxide, sulfur dioxide, nitrogen oxides, and oxygen.

Routine direct disposal of wastes to the Snake River Plain Aquifer ceased in 1984. Liquid wastes are now disposed to sewage lagoons, seepage ponds, industrial waste ponds, industrial waste ditches, and sewage treatment facilities. The liquid effluent monitoring program is presently operated by LMITCO for effluent streams at CFA, INTEC, RWMC, TAN, and TRA. In addition, monitoring is performed by the program for INEEL-related facilities located in the city of Idaho Falls. A total of 15 discharge points were routinely monitored for nonradiological parameters in 1997

ANL-W monitors the Industrial Waste Pond and the Secondary Sanitary Lagoon monthly for nonradiological constituents when these ponds are not frozen or dry.

\section{Facility Monitoring Programs}

Several INEEL facilities conduct environmental surveillance within, and around the perimeters, of their facilities. The scope of each of these programs varies with the nature of the facility being monitored. One such program, the Radiological Environmental Surveillance Program, monitors LMITCO waste management facilities including RWMC and WERF. Samples are taken of air, water, soil, and vegetation. Environmental radiation measurements are also made, and visual inspections of the facilities are conducted. Other monitoring programs are in place at ANL-W, INTEC, and the Specific Manufacturing Capability facility located at TAN.

\section{Drinking Water Programs}

The LMITCO Drinking Water Program monitors production and drinking water wells for radiological, chemical and bacteriological contaminants at all INEEL facilities operated by the company. Currently, 17 wells and 10 distribution systems are routinely monitored. All analyses for the program are conducted using laboratories certified by the state of Idaho or laboratories certified in other states, where this certification is accepted by the state of Idaho NRF maintains a separate program for sampling drinking water at that facility. Radiological and bacteriological samples from ANL-W are sent to LMITCO for analysis. ANL-W conducts a sep.arate program for chemical monitoring.

Radiological Monitoring. Onsite drinking water samples are collected quarterly for radiological analysis from production wells and distribution system in use at active LMITCO facilities. Analyses were performed by Paragon Laboratory during 1997. Each water sample is submitted for gross analyses for alpha and beta-emitting radionuclides. Tritium analyses are also performed on all drinking water samples. Strontium-90 analyses are performed on quarterly samples from drinking water wells in the INTEC area, because water quality monitoring data indicates these wells may be affected by a ${ }^{90} \mathrm{Sr}$ plume.

Bacteriological Monitoring. Potable water at the INEEL is monitored for coliform bacteria monthly by the LMITCO Environmental Hygiene Laboratory. If indications of contamination by bacteria are found in a sample, that particular drinking water system is disinfected, resampled, and tested again, until it is clear of bacteria. 
Corrective action to purify the water may vary among facilities.

Chemical Monitoring. The LMITCO Drinking Water Program routinely samples drinking water from wells and distribution systems at facilities at the INEEL for volatile organic compounds. A program to monitor lead and copper in drinking water in accordance with EPA regulations has been in place since 1992. The year 1995 concluded three successive years of monitoring lead and copper levels in drinking water. Since regulatory values were not exceeded, and in accordance with regulations, this monitoring has been reduced to once every three years beginning in 1998. Chlorinated drinking water systems are also monitored for total trihalomethanes (bromodichloromethane, bromoform, chloroform, and dibromochloro-methane). Additional sampling is conducted for a variety of inorganic constituents, including metals, nitrates, and dissolved solids.

\section{Storm Water Monitoring Program}

As one of the requirements of the National Pollutant Discharge Elimination System General Permit effective October 1, 1992, the INEEL was required to develop a storm water monitoring program. Sampling of snow melt and rain runoff began in 1993, and in 1997 included 16 sites at eight INEEL facilities. Four sites must be sampled at least twice per year if discharge to "waters of the U.S." occurs to meet permit requirements. The program attempts to sample all locations at least twice yearly.

Samples are collected from storms of at least $0.25 \mathrm{~cm}(0.1 \mathrm{in})$ of precipitation preceded by a minimum of 72 hours without precipitation. Collection, preservation, and analysis of storm water samples are performed in accordance with the National Pollutant Discharge Elimination System Storm Water Sampling Guidance Document and 40 CFR 136.

The general permit does not contain numeric limitations for analytical parameters, except for the runoff from coal piles at INTEC. These are required to have a $\mathrm{pH}$ within the range of 6 to 9 . Other parameters are compared to benchmark concentrations listed in Reference 5-4 to help evaluate the quality of storm water discharges.

\section{Site Environmental Surveillance Program}

General Information. LMITCO and EG\&G, its predecessor as INEEL operating contractor, have conducted the Site Environmental Surveillance Program since January 1994. The program has overall responsibility for sampling of air and soil, and measurement of environmental radiation at onsite locations. For comparison purposes, some sampling is also performed at distant locations. A summary of the program in 1997 is provided in Table 3-1.

Analyses for the Site Environmental Surveillance Program were performed primarily by the Radiological Measurement Laboratory located at TRA. A database containing sampling and analytical information is maintained by LMITCO through the computer support group.

Low-volume Air Samplers. Airborne particulate radioactivity is monitored continuously on the INEEL by LMITCO using a network of lowvolume air samplers (Figure 3-2). LMITCO collects air at 12 locations onsite, and at four offsite locations for comparison purposes. Locations of onsite samplers give adequate coverage in the event of releases of radioactivity from INEEL facilities. Each low-volume air sampler maintains an average air flow of about $50 \mathrm{~L} / \mathrm{min}$ $\left(2 \mathrm{ft}^{3} / \mathrm{min}\right.$ ) through a set of filters consisting of a 1.2- $\mu \mathrm{m}$ pore membrane filter followed by a charcoal cartridge. The filters are $99 \%$ efficient for airborne particulate radioactivity and iodides

The particulate filters from the low-volume air samplers are collected and analyzed weekly. All the charcoal cartridges are evaluated individually each week for ${ }^{131}$ I by gamma spectrometry. Particulate filters are analyzed after waiting a 


\begin{tabular}{|c|c|c|c|c|}
\hline \multicolumn{5}{|c|}{$\begin{array}{l}\text { TABLE 3-1. LMITCO SITE ENVIRONMENTAL SURVEILLANCE } \\
\text { RADIOLOGICAL PROGRAM SUMMARY (1997) } \\
\end{array}$} \\
\hline \multirow[b]{2}{*}{ Medium Sampled } & \multirow[b]{2}{*}{ Type of Analysis } & \multicolumn{2}{|c|}{ Number of Locations and Frequency } & \multirow{2}{*}{$\begin{array}{c}\text { Approximate } \\
\text { Minimum Detectable } \\
\text { Concentration }\end{array}$} \\
\hline & & Onsite & Offsite & \\
\hline Air (Low-Volume) & $\begin{array}{c}\text { Gross alpha } \\
\text { Gross beta } \\
\text { Specific gamma } \\
\mathrm{Pu} \\
\mathrm{Am} \\
{ }^{90} \mathrm{Sr} \\
\text { Particulate matter }\end{array}$ & $\begin{array}{l}12 \text { weekly } \\
12 \text { weekly } \\
12 \text { quarterly } \\
12 \text { quarterly } \\
12 \text { quarterly } \\
12 \text { quarterly } \\
12 \text { quarterly } \\
\end{array}$ & $\begin{array}{l}4 \text { weekly } \\
4 \text { weekly } \\
4 \text { quarterly } \\
4 \text { quarterly } \\
4 \text { quarterly } \\
4 \text { quarterly } \\
4 \text { quarterly }\end{array}$ & $\begin{array}{l}1 \times 10^{-15} \mu \mathrm{Ci} / \mathrm{mL} \\
5 \times 10^{-15} \mu \mathrm{Ci} / \mathrm{mL} \\
1 \text { to } 10 \times 10^{-15} \mu \mathrm{Ci} / \mathrm{mL} \\
2 \times 10^{-18} \mu \mathrm{Ci} / \mathrm{mL} \\
2 \times 10^{-18} \mu \mathrm{Ci} / \mathrm{mL} \\
3.5 \times 10^{-17} \mu \mathrm{Ci} / \mathrm{mL} \\
10 \mu \mathrm{g} / \mathrm{m}^{3}\end{array}$ \\
\hline $\begin{array}{l}\text { Air (Tritium } \\
\text { Samplers) }\end{array}$ & ${ }^{3} \mathrm{H}$ & 2 at 1 to $2 /$ quarter & ---- & $1 \times 10^{-11} \mu \mathrm{Ci} / \mathrm{mL}$ \\
\hline Soil & $\begin{array}{c}\text { Specific gamma } \\
\mathrm{Pu} \\
\mathrm{Am} \\
{ }^{90} \mathrm{Sr} \\
\end{array}$ & $\begin{array}{l}\text { Varies annually } \\
\text { Varies annually } \\
\text { Varies annually } \\
\text { Varies annually } \\
\end{array}$ & $\begin{array}{l}-\cdots \\
-\cdots- \\
-\cdots- \\
-\cdots\end{array}$ & $\begin{array}{llll}1 \times 10^{-7} & \mu \mathrm{Ci} / g \\
3 \times & 10^{-9} & \mu \mathrm{Ci} / g \\
3 \times & 10^{-9} & \mu \mathrm{Ci} / \mathrm{g} \\
6 \times & 10^{-8} & \mu \mathrm{Ci} / g \\
\end{array}$ \\
\hline $\begin{array}{l}\text { Direct Radiation } \\
\text { Exposure } \\
\text { (Thermoluminescent } \\
\text { Dosimeters) }\end{array}$ & Ionizing Radiation & 135 semiannually & 13 semiannually & $5 \mathrm{mR}$ \\
\hline $\begin{array}{l}\text { Direct Radiation } \\
\text { Exposure (Radiation } \\
\text { Surveys) } \\
\end{array}$ & Gamma Radiation & $\begin{array}{c}\text { Facilities }^{\mathrm{b}} \\
\text { INEEL Roads }\end{array}$ & $-\cdots$ & Not Applicable \\
\hline
\end{tabular}

minimum of four days to allow the naturally occurring, short-lived radon and thoron daughters to decay. Analyses for gross (nonspecific) alpha and gross beta activity are performed on a proportional counter.

Specific radionuclide analyses are more sensitive than gross alpha and gross beta analyses for detecting concentrations of manmade radionuclides in air. The particulate filters of the lowvolume samplers are composited by location at the end of each quarter, and all composites are analyzed for specific radionuclides by gamma spectrometry. Composites are then submitted for analyses for alpha-emitting radionuclides $\left({ }^{238} \mathrm{Pu}\right.$, ${ }^{239 / 240} \mathrm{Pu}$, and ${ }^{241} \mathrm{Am}$ ) and ${ }^{90} \mathrm{Sr}$. The analyses for alpha-emitting nuclides use chemical separation techniques followed by alpha spectrometry; for
${ }^{90} \mathrm{Sr}$, the chemical separation is followed by beta counting.

Atmospheric Moisture Samplers. Samplers for tritium in water vapor in the atmosphere are located at the EFS and Van Buren locations on the INEEL. In these samplers, air is passed through a column of molecular sieve at a rate of approximately $0.5 \mathrm{~L} / \mathrm{min}\left(1 \mathrm{ft}^{3} / \mathrm{hr}\right)$. Water vapor in the air is absorbed by the molecular sieve in the column; columns are changed when the molecular sieve absorbs sufficient moisture to obtain a sample (typically from one to three times per quarter). Tritium concentrations are then determined by liquid scintillation counting of the water extracted from the molecular sieve columns. 


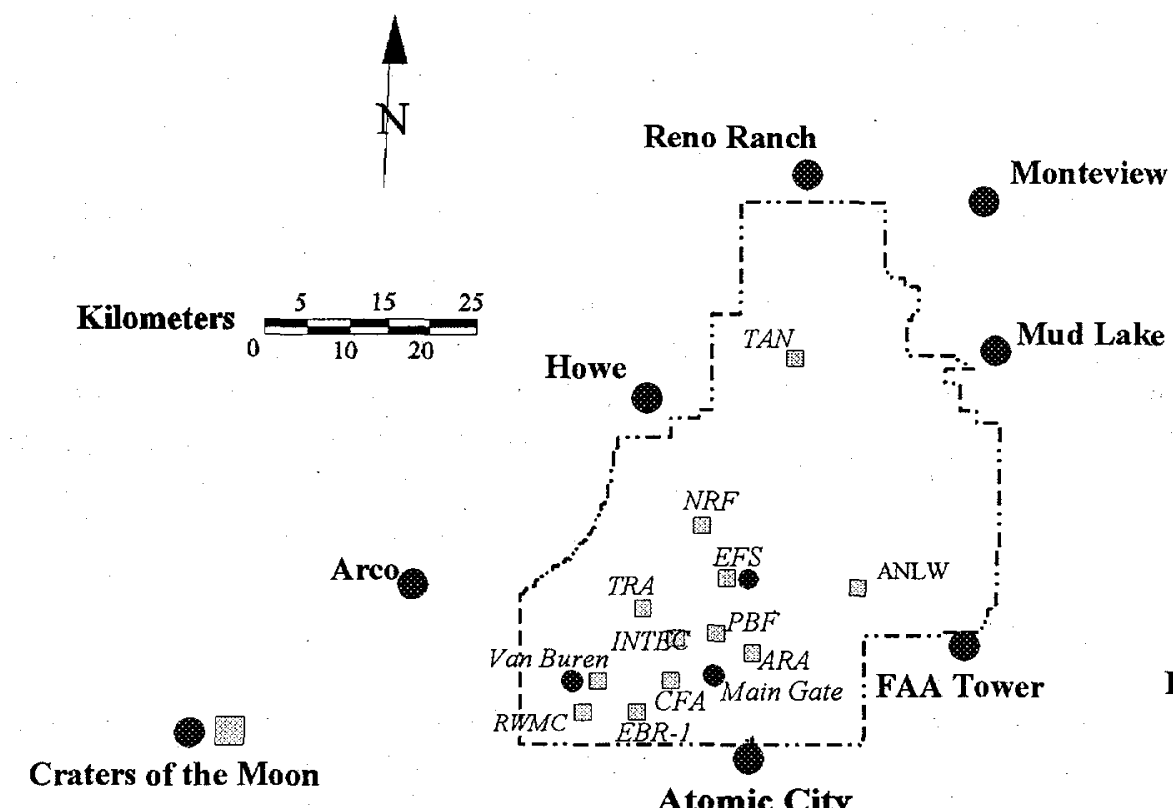

Rexburg

Idaho Falls

Atomic City

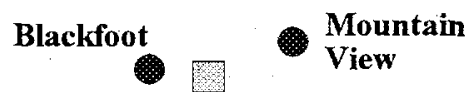

- Foundation Low-volume Air Sampler Location

- LMITCO Low-volume Air Sampler Location

Figure 3-2. Low-volume Air Sampler Locations

Nitrogen Dioxide/Sulfur Dioxide Monitoring.

To fulfill one of the conditions specified in the Permit to Construct, Idaho Chemical Processing Plant Nitrogen Oxide Sources, two nitrogen oxide monitoring stations (which measure NO and $\mathrm{NO}_{2}$, collectively called $\mathrm{NO}_{\mathrm{x}}$ ) are operated by LMITCO. These are located near the intersection of U.S. Highway 20/26 and Van Buren Boulevard and at EFS. The analyzers used are designated as EPA equivalent methods. One EPA equivalent method sulfur dioxide analyzer is operated at the Van Buren location in addition to the nitrogen dioxide analyzer.

Environmental Dosimeters. Environmental dosimeters, known as thermoluminescent dosimeters (TLDs), are used to measure ionizing rad- iation exposures. The TLDs measure ionizing radiation exposures from natural radioactivity in the air and soil, cosmic radiation from space, fallout from nuclear weapons tests, radioactivity from fossil fuel burning, and radioactive effluents from INEEL operations and other industrial processes.

At each location, a dosimeter card containing five individual chips is placed $1 \mathrm{~m}(3 \mathrm{ft}$ ) above ground level. LMITCO maintained dosimeters at 13 offsite locations and 135 locations on the INEEL. The dosimeter card at each location is changed semiannually, and cumulative gamma radiation is measured by the LMITCO Dosimetry Unit. 


\section{INEEL Offsite Environmental Surveillance Program}

General Information. The Environmental Science and Research Foundation is a nonprofit organization which conducts environmental monitoring, ecological research, and environmental services independent of the $M \& O$ contractor at the INEEL. The Foundation has, since April 1994, performed the INEEL Offsite Environmental Surveillance Program for DOE-ID [Table 3-2].

The Environmental Science and Research Foundation uses independent offsite laboratories to perform analyses for the environmental surveillance program. The majority of radiological analyses, including gross alpha/gross beta, tritium, and gamma spectrometry analyses, are conducted by the Idaho State University Environmental Assessment Laboratory. Radiochemical analyses, such as ${ }^{90} \mathrm{Sr}$ and transuranics, are performed at Quanterra Inc., an independent commercial laboratory. Analyses for the Interagency Monitoring of Protected Visual Environments (IMPROVE) program are performed at the University of California, Davis Crocker Nuclear Laboratory. The University of Toronto's IsoTrace Laboratory conducted ${ }^{129} \mathrm{I}$ analyses in 1997.

Low-volume Air Samplers. The Foundation maintains a network of low-volume air samplers (Figure 3-2) to monitor for airborne radioactivity. Twelve samplers are located at offsite locations. In addition, three samplers are operated on the INEEL for comparison purposes. Each low-volume air sampler maintains an average air flow of about $50 \mathrm{~L} / \mathrm{min}\left(2 \mathrm{ft}^{3} / \mathrm{min}\right)$ through a set of filters consisting of a $1.2-\mu \mathrm{m}$ pore membrane filter followed by a charcoal cartridge. The filters are $99 \%$ efficient for airborne particulate radioactivity and iodides.

The particulate filters from the low-volume air samplers are collected and analyzed weekly. Charcoal cartridges are evaluated in batches of up to eight cartridges for ${ }^{131} \mathrm{I}$ using gamma spec- trometry. If any activity is noted in a batch, each filter in the batch can then be recounted individually.

Particulate filters are analyzed weekly for gross alpha and gross beta concentrations using an automatic proportional counting system. Filters are analyzed after waiting a minimum of four days to allow naturally occurring radionuclides to decay. Gross alpha and gross beta analyses are used as a screening technique, to provide timely information on levels of radioactivity in the environment.

The particulate filters from the low-volume samplers are composited by location at the end of each quarter and analyzed for specific radionuclides. All composites are analyzed for specific gamma-emitting nuclides by gamma spectrometry. Selected composites are then submitted for analyses for transuranic radionuclides $\left({ }^{238} \mathrm{Pu}\right.$, ${ }^{239 / 240} \mathrm{Pu}$, and ${ }^{241} \mathrm{Am}$ ) or ${ }^{90} \mathrm{Sr}$. The analyses for transuranic nuclides use chemical separation techniques followed by alpha spectrometry; for ${ }^{90} \mathrm{Sr}$, the chemical separation is followed by beta. counting.

Measurements of total suspended particulates are performed on the particulate filters from the low-volume filters. Clean filters are weighed at the beginning of each quarter and filter composites are weighed at the end of the quarter. The concentration of total suspended particulates is calculated by dividing the amount of material collected on the filters by the total volume of air passing though the filters.

Atmospheric Moisture. Samplers to collect atmospheric water vapor for tritium analyses are located in Idaho Falls, Blackfoot, Atomic City, and Rexburg. In these samplers, air is passed through a column of silica gel at a rate of approximately $0.3 \mathrm{~L} / \mathrm{min}\left(0.01 \mathrm{ft}^{3} / \mathrm{min}\right)$. Water vapor in the air is absorbed by the gel in the column; columns are changed when the gel absorbs sufficient moisture to obtain a sample (typically from one to three times per quarter). Tritium concentrations are then determined by liquid 


\begin{tabular}{|c|c|c|c|c|}
\hline \multicolumn{5}{|c|}{$\begin{array}{l}\text { TABLE 3-2. ENVIRONMENTAL SCIENCE AND RESEARCH FOUNDATION ENVIRONMENTA } \\
\text { SURVEILLANCE RADIOLOGICAL PROGRAM SUMMARY (1997) }\end{array}$} \\
\hline \multirow[b]{2}{*}{ Medium Sampled } & \multirow[b]{2}{*}{ Type of Analysis } & \multicolumn{2}{|c|}{ Number of Locations and Frequency } & \multirow{2}{*}{$\begin{array}{c}\sim \text { Minimum Detectable } \\
\text { Concentration }\end{array}$} \\
\hline & & Onsite & Offsite & \\
\hline $\begin{array}{l}\text { Air (Low-Volume) } \\
\text { (particulate filter) }\end{array}$ & $\begin{array}{c}\text { Gross alpha } \\
\text { Gross beta } \\
\text { Specific gamma } \\
{ }^{238} \mathrm{Pu} \\
{ }^{239 / 240} \mathrm{Pu} \\
{ }^{24 i} \mathrm{Am} \\
{ }^{90} \mathrm{Sr} \\
\text { Particulate matter }\end{array}$ & $\begin{array}{l}3 \text { weekly } \\
3 \text { weekly } \\
3 \text { quarterly } \\
1-2 \text { quarterly } \\
1-2 \text { quarterly } \\
1-2 \text { quarterly } \\
1-2 \text { quarterly } \\
3 \text { quarterly }\end{array}$ & $\begin{array}{r}12 \text { weekly } \\
12 \text { weekly } \\
12 \text { quarterly } \\
4 \text { quarterly } \\
4 \text { quarterly } \\
4 \text { quarterly } \\
4 \text { quarterly } \\
12 \text { quarterly }\end{array}$ & $\begin{array}{c}1 \times 10^{-15} \mu \mathrm{Ci} / \mathrm{mL} \\
3 \times 10^{-15} \mu \mathrm{Ci} / \mathrm{mL} \\
3 \times 10^{-16} \mu \mathrm{Ci} / \mathrm{mL} \\
2 \times 10^{-18} \mu \mathrm{Ci} / \mathrm{mL} \\
3 \times 10^{-18} \mu \mathrm{Ci} / \mathrm{mL} \\
2 \times 10^{-18} \mu \mathrm{Ci} / \mathrm{mL} \\
3 \times 10^{-17} \mu \mathrm{Ci} / \mathrm{mL} \\
10 \mu \mathrm{g} / \mathrm{m}^{3}\end{array}$ \\
\hline Air (charcoal cartridge) & ${ }^{131} \mathrm{I}$ & 3 weekly & 12 weekly & $4 \times 10^{-15} \mu \mathrm{Ci} / \mathrm{mL}$ \\
\hline $\operatorname{Air}\left(\mathbf{P M}_{10}\right)$ & & None & 3 weekly & \\
\hline Air (IMPROVE) & $\mathrm{H}, \mathrm{Na}-\mathrm{Pb}, \mathrm{PM}_{2.5}$ & 1 biweekly & 1 biweekly & \\
\hline $\begin{array}{l}\text { Air } \\
\text { (Atmospheric Moisture) }\end{array}$ & ${ }^{3} \mathrm{H}$ & None & $\begin{array}{l}4 \text { locations, } \\
2 \text { to } 4 / \text { quarter }\end{array}$ & $4 \times 10^{-12} \mu \mathrm{Ci} / \mathrm{mL}$ \\
\hline Air (Precipitation) & ${ }^{3} \mathrm{H}$ & 1 weekly/ I monthly & 1 monthly & $1 \times 10^{-7} \mu \mathrm{Ci} / \mathrm{mL}$ \\
\hline Drinking Water & $\begin{array}{c}\text { Gross alpha } \\
\text { Gross beta } \\
{ }^{3} \mathrm{H} \\
\end{array}$ & $\begin{array}{l}\text { None } \\
\text { None } \\
\text { None } \\
\end{array}$ & $\begin{array}{l}13 \text { semiannually } \\
13 \text { semiannually } \\
13 \text { semiannually } \\
\end{array}$ & $\begin{array}{l}3 \times 10^{-9} \mu \mathrm{Ci} / \mathrm{mL} \\
2 \times 10^{-9} \mu \mathrm{Ci} / \mathrm{mL} \\
1 \times 10^{-7} \mu \mathrm{Ci} / \mathrm{mL}\end{array}$ \\
\hline Surface Water & $\begin{array}{l}\text { Gross alpha } \\
\text { Gross beta } \\
{ }^{3} \mathrm{H} \\
\end{array}$ & $\begin{array}{l}\text { None } \\
\text { None } \\
\text { None }\end{array}$ & $\begin{array}{l}5 \text { quarterly } \\
5 \text { quarterly } \\
5 \text { quarterly }\end{array}$ & $\begin{array}{l}3 \times 10^{-9} \mu \mathrm{Ci} / \mathrm{mL} \\
2 \times 10^{-9} \mu \mathrm{Ci} / \mathrm{mL} \\
1 \times 10^{-7} \mu \mathrm{Ci} / \mathrm{mL}\end{array}$ \\
\hline Animal Tissue (Sheep) ${ }^{\mathrm{a}}$ & Specific gamma & 4 annually & 2 annually & $5 \times 10^{-9} \mu \mathrm{Ci} / \mathrm{g}$ \\
\hline Animal Tissue (Game) & Specific gamma & Varies annually $^{\mathrm{b}}$ & --.- & $5 \times 10^{-9} \mu \mathrm{Ci} / \mathrm{g}$ \\
\hline Foodstuffs (Milk) & $\begin{array}{c}{ }^{131} \mathrm{I} \\
{ }^{131} \mathrm{I} \\
{ }^{129} \mathrm{I} \\
{ }^{90} \mathrm{Sr} \\
{ }^{3} \mathrm{H}\end{array}$ & $\begin{array}{l}\text { None } \\
\text { None } \\
\text { None } \\
\text { None } \\
\text { None } \\
\end{array}$ & $\begin{array}{l}1 \text { weekly } \\
9 \text { monthly } \\
5 \text { quarterly } \\
9 \text { annually } \\
9 \text { annually }\end{array}$ & $\begin{array}{r}2 \times 10^{-9} \mu \mathrm{Ci} / \mathrm{mL} \\
2 \times 10^{-9} \mu \mathrm{Ci} / \mathrm{mL} \\
5-25 \times 10^{6} \text { atoms } / \mathrm{g}^{\mathrm{c}} \\
3 \times 10^{-10} \mu \mathrm{Ci} / \mathrm{mL} \\
1 \times 10^{-7} \mu \mathrm{Ci} / \mathrm{mL}\end{array}$ \\
\hline Foodstuffs (Potatoes) & $\begin{array}{l}\text { Specific gamma } \\
{ }^{90} \mathrm{Sr} \\
\end{array}$ & $\begin{array}{l}\text { None } \\
\text { None } \\
\end{array}$ & $\begin{array}{l}8 \text { annually } \\
8 \text { annually }\end{array}$ & $\begin{array}{l}4 \times 10^{-9} \mu \mathrm{Ci} / \mathrm{g} \\
5 \times 10^{-9} \mu \mathrm{Ci} / \mathrm{g}\end{array}$ \\
\hline Foodstuffs (Wheat) & $\begin{array}{l}\begin{array}{l}\text { Specific gamma } \\
{ }^{90} \mathrm{Sr}\end{array} \\
\end{array}$ & $\begin{array}{l}\text { None } \\
\text { None }\end{array}$ & $\begin{array}{l}11 \text { annually } \\
11 \text { annually }\end{array}$ & 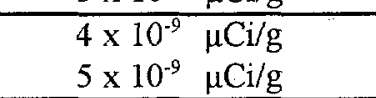 \\
\hline Foodstuffs (Lettuce) & $\begin{array}{c}\text { Specific gamma } \\
{ }^{90} \mathrm{Sr}\end{array}$ & $\begin{array}{l}\text { None } \\
\text { None }\end{array}$ & $\begin{array}{l}9 \text { annually } \\
9 \text { annually }\end{array}$ & $\begin{array}{l}1 \times 10^{-7} \mu \mathrm{Ci} / \mathrm{g} \\
2 \times 10^{-7} \mu \mathrm{Ci} / \mathrm{g}\end{array}$ \\
\hline Soil & $\begin{array}{c}\text { Specific gamma } \\
\mathrm{Pu} \\
\mathrm{Am} \\
{ }^{90} \mathrm{Sr} \\
\end{array}$ & $\begin{array}{l}\text { None } \\
\text { None } \\
\text { None } \\
\text { None } \\
\end{array}$ & $\begin{array}{l}12 \text { biennially } \\
12 \text { biennially } \\
12 \text { biennially } \\
12 \text { biennially } \\
\end{array}$ & $\begin{array}{ll}4 \times 10^{-8} & \mu \mathrm{Ci} / g \\
2 \times 10^{-9} & \mu \mathrm{Ci} / g \\
3 \times 10^{-9} & \mu \mathrm{Ci} / g \\
9 \times 10^{-8} & \mu \mathrm{Ci} / g \\
\end{array}$ \\
\hline $\begin{array}{l}\text { Direct Radiation Exposure } \\
\text { (Thermoluminescent } \\
\text { Dosimeters) }\end{array}$ & $\begin{array}{l}\text { Ionizing } \\
\text { Radiation }\end{array}$ & None & 14 semiannually & $5 \mathrm{mR}$ \\
\hline $\begin{array}{l}\text { "Onsite" animals grazed onsite for } \\
\text { Only road-killed game animals are } \\
\text { In terms of grams of processed dry }\end{array}$ & $\begin{array}{l}\text { st four weeks before } \\
\text { led onsite. No contt } \\
\text { solids }\end{array}$ & $\begin{array}{l}\text { ffsite" anin } \\
\text { ollected exc }\end{array}$ & $\begin{array}{l}\text { er grazed onsite anc } \\
\text { c ecological studie: }\end{array}$ & controls. \\
\hline
\end{tabular}


scintillation counting of the water extracted from the silica gel columns.

Precipitation. Monthly precipitation samples are collected on the INEEL at CFA and at the offsite location of Idaho Falls. In addition, weekly samples are collected at EFS when available. A portion of each precipitation sample is submitted for tritium analysis by liquid scintillation counting.

Fine Particulates. The Foundation established samplers which selectively measure the concentration of fine particulates less than $10 \mu \mathrm{m}$ in aerodynamic diameter, known as $\mathrm{PM}_{10}$ samplers, as part of the Community Monitoring Stations in Rexburg and Blackfoot. Sampling at these stations began in 1996. An additional sampler began operation in Atomic City in March 1997. Fine particulate samplers operate for 24 hours, midnight to midnight, every sixth day. Clean quartz fiber filters are weighed before and after sampling to determine the amount of material collected.

IMPROVE Samplers. The National Park Service, in cooperation with other federal land management agencies (U.S. Forest Service, U.S. Fish \& Wildlife Service, Bureau of Land Management) began the IMPROVE program in 1985 . This program was an extension of an earlier Environmental Protection Agency program to measure fine $(<2.5 \mu \mathrm{m})$ particles, the largest cause of visibility degradation.

In May 1992, one IMPROVE sampler was established at CFA on the INEEL and a second was located at Craters of the Moon National Monument, as part of the nationwide network. The two samplers each collect two 24-hour samples weekly of fine particulates $<2.5 \mu \mathrm{m}$ in diameter. Analyses are performed for mass, optical absorption, hydrogen, carbon, nitrogen, and oxygen plus elements from sodium through lead on the periodic table.

Water. In 1997 the Environmental Science and Research Foundation collected semiannual drink- ing water samples from boundary and distant communities, and surface water samples from the Snake River at Idaho Falls and Bliss. In addition, quarterly drinking water and surface water samples were collected from the Magic Valley area. Each water sample collected was submitted for gross analyses for alpha and beta emitting radionuclides, as well as for tritium analysis using liquid scintillation.

Milk. Milk samples were collected from both commercial and single-family dairies (Figure 3-3). A 4-L (1-gal) sample was obtained from each location monthly, except in Idaho Falls where a sample was collected weekly. Milk from each location was analyzed for ${ }^{131} \mathrm{I}$, and one analysis for ${ }^{90} \mathrm{Sr}$ and tritium at each location was performed during the year.

Lettuce. Lettuce samples were obtained from private gardens in communities in the vicinity of the INEEL. Samples were washed to remove any soil as in normal food preparation, dried, reduced to a powdered form, and weighed. All lettuce samples were analyzed for ${ }^{90} \mathrm{Sr}$ and gammaemitting radionuclides.

Wheat. Wheat samples are collected from grain. elevators in the region surrounding the NEEL. All wheat samples are analyzed for ${ }^{90} \mathrm{Sr}$ and gamma-emitting radionuclides.

Potatoes. Potato samples were collected from storage warehouses in the INEEL vicinity. The samples, with cleaned skins included, were processed and weighed. All potato samples were analyzed for ${ }^{90} \mathrm{Sr}$ and gamma-emitting radionuclides.

Sheep. Samples of tissue (muscle, liver, and thyroid) are collected from sheep grazing on the INEEL. Control samples are collected from Blackfoot. The muscle and liver are processed and analyzed by gamma spectrometry. The thyroid is placed in a vial and analyzed specifically for ${ }^{131} \mathrm{I}$. 


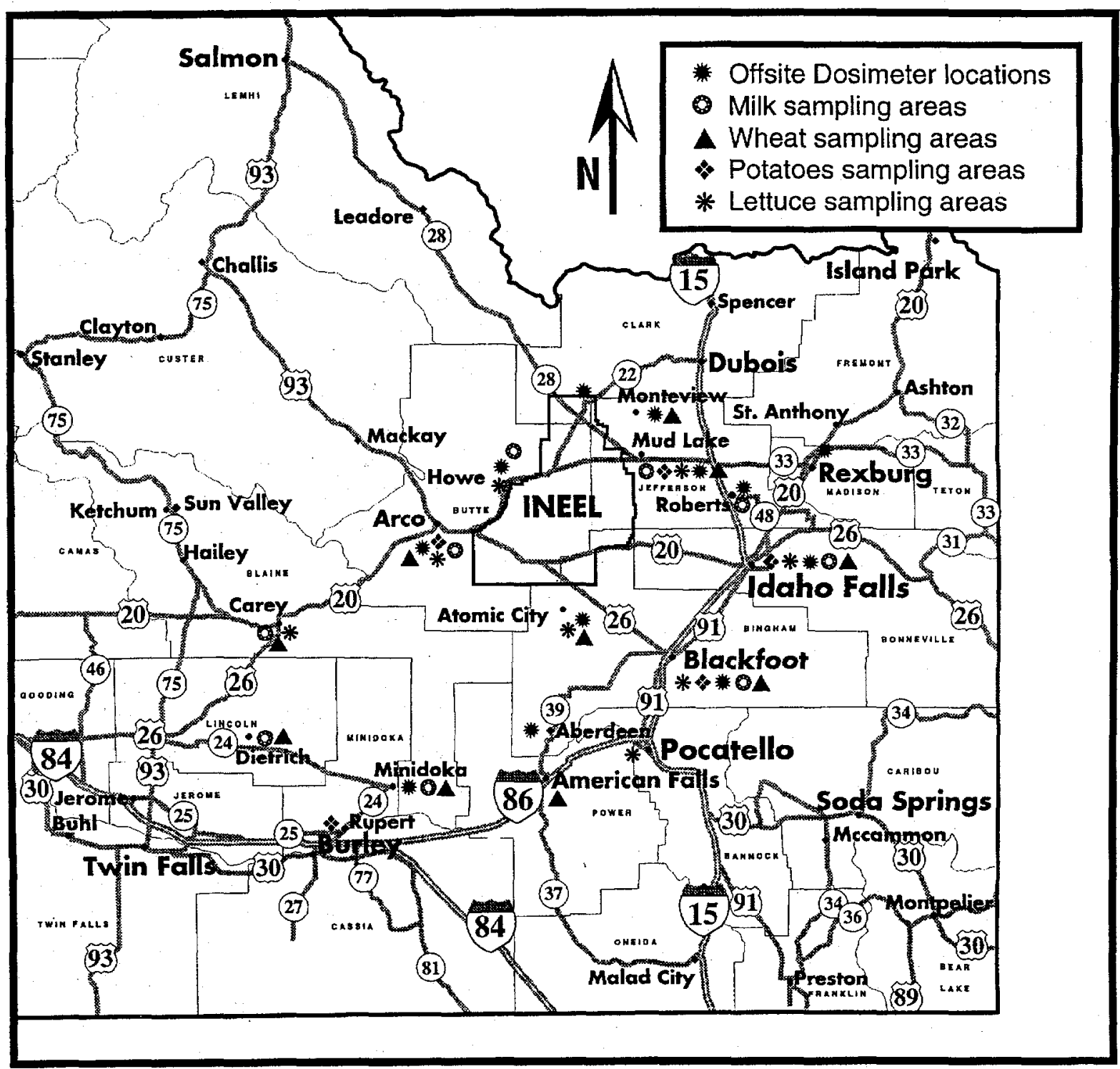

Figure 3.3 Offsite Foodstuff Sampling and Environmental Dosimeter Locations

Game Animals. Selected tissues (muscle, liver, and thyroid) are collected from game animals accidentally killed on INEEL roads. Thyroid samples are placed in vials and analyzed by gamma spectrometry specifically for ${ }^{131} \mathrm{I}$. Muscle and liver samples are processed, placed in a plastic container, and weighed prior to gamma spectrometry analysis.

Waterfowl samples are collected from waste disposal ponds at four facilities on the INEEL to evaluate the potential for exposure to members of the public who might consume these game animals. Control samples are also taken in areas distant from the INEEL. Waterfowl samples are separated into an external portion (consisting of the skin and feathers), edible portion (muscle tissue), and remainder portion. All samples are analyzed by gamma spectrometry. Selected samples are also analyzed for ${ }^{90} \mathrm{Sr}$ and transuranic radionuclides. 
Soil. To establish background levels of natural and fallout radioactivity in surface soil and to assess any potential buildup of radioactivity from INEEL operations, soil samples are collected from distant and boundary locations in each even-numbered year. No soil sampling was performed in 1997.

Environmental Dosimeters. Environmental dosimeters, commonly called thermoluminescent dosimeters (TLDs), are used to measure ionizing radiation exposures at offsite locations. The TLDs measure ionizing radiation exposures from all sources, including natural radioactivity, cosmic radiation, fallout from nuclear weapons tests, radioactivity from fossil fuel burning, and radioactive effluents from INEEL operations and other industrial processes.

At each location, a dosimeter card containing

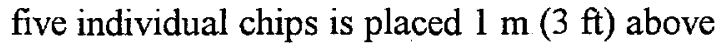
ground level. Dosimeters are changed twice per year at each of the 13 sampling locations (Figure 3-3).

\section{USGS Ground-water Monitoring Program}

The USGS INEEL Project Office has conducted ground- and surface water monitoring at the Site since 1949. The USGS currently maintains 125 aquifer observation wells on or near the INEEL. An additional 45 wells are available for sampling perched ground-water bodies. In addition, more than 120 auger holes have been drilled to monitor shallow perched ground-water bodies (see Chapter 6).

The USGS monitors water levels in wells and radiological and nonradiological substances in water from their observation wells and auger holes on schedules ranging from monthly to annually [Table 3-3]. The USGS also conducts special studies of the ground water of the Snake River Plain. A summary of these studies is provided in Chapter 6 of this report. These special studies provide more specific geological and hydrological information on the flow and recharge of the aquifer and the movements of radioactive and nonradioactive substances in the ground water.

Chemical Monitoring. Water samples from selected onsite production wells and groundwater monitoring wells are collected by USGS personnel on schedules ranging from monthly to annually. These samples are submitted to the USGS National Water Quality Laboratory in Arvada, Colorado, for analysis of 60 purgeable organic compounds. Sampling for trace elements is also performed by the USGS. Other parameters in ground water are measured based on the: needs of special studies that are being conducted by the organization. Results of these studies are: published in USGS Water Resources Investigation Reports and Open-File Reports on a periodic basis.

\section{Meteorological Monitoring Program}

Meteorological monitoring began at the INEEL in 1949. The NOAA Air Resources Laboratory, located in Idaho Falls, currently maintains a network of 30 meteorological stations in the vicinity of the Site. These stations provide continuous measurement of a variety of parameters, including temperature at two or three levels, wind direction and speed, relative humidity, and precipitation. In addition, continuous measurements are also made using a wind-profiling radar system and radio acoustic sounding system located on the INEEL. Data are transmitted via radio to the NOAA Idaho Falls facility, where they are stored in a computerized archive.

\section{INEEL Oversight Program}

Introduction. Since 1990, the state of Idaho has operated an environmental surveillance program as part of the INEEL Oversight Program. This program includes the collection and analysis of air, precipitation, atmospheric moisture, water, soil and milk samples on and around the INEEL. In addition, the program has a network of pressurized ion chambers, electret ion chambers, and environmental dosimeters. Many of these sam- 
ples are taken simultaneously with other organizations performing environmental surveillance, or are at sites colocated with other organizations. All radiological analyses are performed by the Idaho State University Environmental Monitoring Laboratory. The Oversight Program recently completed a report detailing results obtained by the program [Reference 3-5]. 


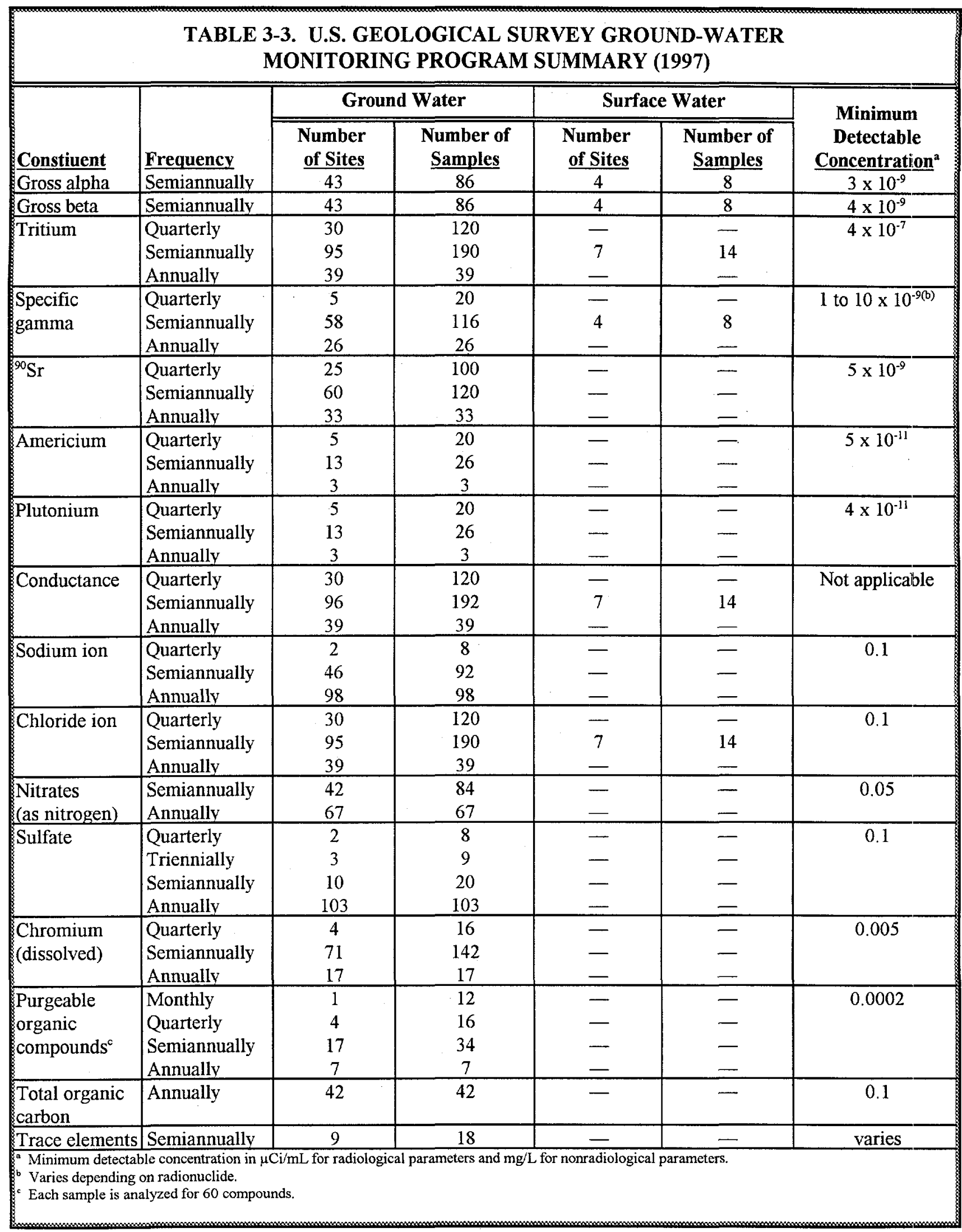




\section{Summary of Chapter 4 \\ Environmental Radiological Program Results}

The Environmental Science and Research Foundation and Lockheed Martin Idaho Technologies Company (LMITCO) conduct environmental surveillance programs on and around the Idaho National Engineering and Environmental Laboratory (INEEL) to monitor potential pathways by which radionuclides could reach members of the public and workers at the INEEL. These programs collect samples of a variety of media, including air, water, soil, and foodstuffs such as milk, wheat, lettuce, potatoes, livestock, and game animals. Direct measurements of radiation in the environment are also made. This chapter provides the results obtained during 1997 for these environmental media, with tables and graphs used to illustrate trends in these data over the past several years. When appropriate, results collected from samples taken on or near the INEEL are compared to results from distant locations to determine if there may be any effect on the environment from INEEL operations.

Section 4.1: Low-volume air sampling, by both the Foundation and LMITCO, showed no evidence of impacts to the offsite environment from INEEL activities. In statistical comparisons of data from Foundation sampling stations, one boundary station, two INEEL stations, and the three INEEL stations as a group had annual mean gross beta concentrations statistically greater than the distant group annual mean for gross beta. For LMITCO, five onsite sampling stations had annual mean gross beta concentrations statistically greater than the distant group annual mean for gross beta. Atmospheric moisture and precipitation samples indicated no apparent effects from INEEL operations.

Section 4.2: Offsite drinking and surface water samples indicated no concentrations of radionuclides above those observed in recent years. One onsite storm water sample contained a detectable concentration of gross alpha.

Section 4.3: No impact from INEEL operations was detected in offsite foodstuff samples. Samples of big game and sheep showed levels of radionuclides consistent with results of recent years. Waterfowl and doves collected from INEEL waste ponds contained elevated concentrations of several radionuclides from ingestion of food, sediment, and water from the waste disposal ponds.

Section 4.4: Offsite environmental (ionizing) radiation measurements indicated no impact from INEEL operations. Onsite measurements indicated elevated levels of environmental radiation in the vicinity of several facilities due to radioactive materials storage areas and contaminated soils. 



\section{ENVIRONMENTAL RADIOLOGICAL PROGRAM RESULTS}

\subsection{AIR}

\section{Low-volume Charcoal Cartridges}

Both LMITCO and the Environmental Science and Research Foundation collect charcoal cartridges weekly and scan each week's filters in a batch by gamma spectroscopy for gamma-emitting radionuclides. If traces of any anthropogenic radionuclide are detected, the filters are analyzed individually. LMITCO analyzed a total of 970 cartridges specifically for ${ }^{131}$ I. The Foundation analyzed 873 cartridges for the same radionuclide. It was not detected in any sample at a minimum detectable concentration of $4 \times 10^{-15} \mu \mathrm{Ci} / \mathrm{mL}$.

\section{Low-volume Gross Alpha}

Gross alpha concentrations found in Foundation samples, both onsite and offsite, were consistently higher than those found in LMITCO samples at common locations (Table 4-1). This difference is likely due to differences in laboratory analytical techniques and instrumentation. Both sets of data indicated, however, that gross alpha concentrations were generally higher at distant locations than at boundary and onsite locations. Only one LMITCO monthly mean concentration, from the Experimental Breeder Reactor-1 (EBR1) during September, was statistically higher than the distant mean concentration for the same time period.

\section{Low-volume Gross Beta}

As with gross alpha, concentrations of gross beta in Foundation samples were consistently higher than those found in LMITCO samples (Table 4-2). Chapter 9 includes a comparison table of weekly gross beta concentrations obtained by LMITCO and the Foundation at common locations.

Weekly gross beta concentrations in Foundation samples ranged from a low of $(7 \pm 1) \times 10^{-15}$ $\mu \mathrm{Ci} / \mathrm{mL}$ during January at FAA Tower to a high of $(56 \pm 3) \times 10^{-15} \mu \mathrm{Ci} / \mathrm{mL}$ at both the Experimental Field Station (EFS) and Mud Lake during the third week in November. LMITCO concentrations ranged from a low of $(-2 \pm 1) \times 10^{-15}$ $\mu \mathrm{Ci} / \mathrm{mL}$ at CFA during March to highs of $(48 \pm$ 3) $\times 10^{-15} \mu \mathrm{Ci} / \mathrm{mL}$ at EBR-1 and EFS, also during the third week of November. Air filters from the third week in November did not contain above-normal concentrations of man-made radionuclides, and there is no reason to believe that these high gross beta activities were caused by INEEL operations. However, NOAA records of barometric pressure and wind speed at CFA, as well as regional weather charts for this period, indicate a high pressure area over southern Idaho for most of the week, coupled with lower than normal wind speeds. Under these conditions, with a relatively stagnant atmosphere, concentrations of naturally-occurring radon and thoron daughters can increase to higher than normal levels, leading to higher airborne gross beta activities.

Foundation annual mean gross beta concentrations ranged from $(21 \pm 2) \times 10^{-15} \mu \mathrm{Ci} / \mathrm{mL}$ at Craters of the Moon and FAA Tower to $(27 \pm 3) \times 10^{-15} \mu \mathrm{Ci} / \mathrm{mL}$ at Reno Ranch and EFS (Table 4-2). LMITCO data indicated a range of $(17 \pm 2) \times 10^{-15} \mu \mathrm{Ci} / \mathrm{mL}$ at Craters of the Moon to $(23 \pm 2) \times 10^{-15} \mu \mathrm{Ci} / \mathrm{mL}$ at NRF and TRA (Table 4-2). The mean annual concentration at Reno Ranch was $0.9 \%$ of the derived concentration guide for gross beta activity in air.

Figure 4-1 displays the average weekly gross beta concentrations for the INEEL, boundary, and distant station groups. These data are typical of the annual pattern for gross beta concentrations in air, with higher values generally occurring at the beginning and end of the calendar year during winter inversion conditions.

In general, the levels of airborne radioactivity for the three groups track each other closely throughout the year. This is an indication that 


\begin{tabular}{|c|c|c|c|c|}
\hline \multicolumn{5}{|c|}{ TABLE 4-1. GROSS ALPHA ACTIVITY IN AIR (1997) } \\
\hline \multicolumn{5}{|c|}{ Environmental Science and Research Foundation Data } \\
\hline \multirow[b]{2}{*}{ Group } & \multirow[b]{2}{*}{ Location } & \multirow[b]{2}{*}{$\begin{array}{c}\text { No. of } \\
\text { Samples }\end{array}$} & \multicolumn{2}{|c|}{ Concentration $\left(\times 10^{-15} \mu \mathrm{Ci} / \mathrm{mL}\right)$} \\
\hline & & & $\begin{array}{l}\text { Range of } \\
\text { Samples }\end{array}$ & $\begin{array}{r}\text { Annual } \\
\text { Mean }^{\mathrm{a}} \\
\end{array}$ \\
\hline \multirow[t]{6}{*}{ Distant } & $\overline{\text { Blackfoot }}$ & 52 & $0.7-5.6$ & $2.1 \pm 0.3$ \\
\hline & Mountain View & 52 & $0.8-6.7$ & $2.4 \pm 0.3$ \\
\hline & Craters of the Moon & 51 & $0.1-6.1$ & $1.3 \pm 0.3$ \\
\hline & Idaho Falls & 51 & $0.5-5.6$ & $2.0 \pm 0.3$ \\
\hline & Rexburg & 51 & $0.7-4.5$ & $2.3 \pm 0.3$ \\
\hline & & & Grand Mean ${ }^{a}$ & $2.0 \pm 0.1$ \\
\hline \multirow[t]{8}{*}{ Boundary } & Arco & 52 & $0.4-8.6$ & $1.9 \pm 0.4$ \\
\hline & Atomic City & 52 & $0.4-4.7$ & $1.6 \pm 0.2$ \\
\hline & FAA Tower (Replicate) & $51(52)$ & $0.1-4.3(0.0-9.5)$ & $1.4 \pm 0.3(1.4 \pm 0.4)$ \\
\hline & Howe & 51 & $0.5-7.8$ & $1.7 \pm 0.4$ \\
\hline & Monteview (Replicate) & $52(52)$ & $0.5-6.0(0.3-5.3)$ & $1.9 \pm 0.3(1.7 \pm 0.3)$ \\
\hline & Mud Lake & 48 & $0.4-5.8$ & $2.1 \pm 0.3$ \\
\hline & Reno Ranch & 51 & $0.2-6.7$ & $1.9 \pm 0.3$ \\
\hline & & & Grand Mean ${ }^{a}$ & $1.8 \pm 0.1$ \\
\hline \multirow[t]{4}{*}{ INEEL } & EFS & 51 & $0.3-6.0$ & $1.8 \pm 0.3$ \\
\hline & Main Gate & 52 & $0.3-4.8$ & $1.5 \pm 0.3$ \\
\hline & Van Buren & 52 & $0.3-4.8$ & $1.7 \pm 0.3$ \\
\hline & & & Grand Mean ${ }^{a}$ & $1.7 \pm 0.2$ \\
\hline \multicolumn{5}{|c|}{ LMITCO Data } \\
\hline \multirow[b]{2}{*}{ Group } & & & \multicolumn{2}{|c|}{ Concentration $\left(\times 10^{-15} \mu \mathrm{Ci} / \mathrm{mL}\right)$} \\
\hline & Location & $\begin{array}{c}\text { No. of } \\
\text { Samples }\end{array}$ & $\begin{array}{l}\text { Range of } \\
\text { Samples } \\
\end{array}$ & $\begin{array}{r}\text { Annual } \\
\text { Mean }^{2} \\
\end{array}$ \\
\hline \multirow[t]{5}{*}{ Distant } & Blackfoot & 52 & $-0.8-3.6$ & $1.2 \pm 0.3$ \\
\hline & Craters of the Moon & 52 & $-1.1-2.0$ & $0.5 \pm 0.2$ \\
\hline & Idaho Falls & 52 & $-1.3-2.7$ & $0.9 \pm 0.2$ \\
\hline & Rexburg & 51 & $-0.8-4.4$ & $1.6 \pm 0.3$ \\
\hline & & & Grand Mean ${ }^{a}$ & $1.0 \pm 0.1$ \\
\hline \multirow[t]{13}{*}{ INEEL } & ANL-W & 47 & $-1.2-2.4$ & $0.6 \pm 0.2$ \\
\hline & ARA & 51 & $-1.5-2.2$ & $0.7 \pm 0.2$ \\
\hline & CFA (Replicate) & $50(52)$ & $-1.0-2.7(-0.9-3.7)$ & $0.6 \pm 0.2(0.8 \pm 0.3)$ \\
\hline & EBR-1 & 50 & $-1.4-4.1$ & $0.9 \pm 0.3$ \\
\hline & EFS & 49 & $-0.5-2.9$ & $0.9 \pm 0.3$ \\
\hline & INTEC & 48 & $-2.0-2.3$ & $0.6 \pm 0.3$ \\
\hline & NRF & 51 & $-1.0-4.7$ & $1.0 \pm 0.3$ \\
\hline & PBF & 51 & $-1.9-2.5$ & $0.7 \pm 0.3$ \\
\hline & RWMC & 50 & $-3.5-2.8$ & $0.7 \pm 0.3$ \\
\hline & TAN (Replicate) & $51(52)$ & $-0.5-2.5(-0.7-2.3)$ & $1.0 \pm 0.2(0.8 \pm 0.2)$ \\
\hline & TRA & 51 & $-2.0-3.7$ & $0.8 \pm 0.3$ \\
\hline & Van Buren & 50 & $-1.1-3.5$ & $0.8 \pm 0.3$ \\
\hline & & & Grand Mean ${ }^{a}$ & $0.8 \pm 0.1$ \\
\hline
\end{tabular}


TABLE 4-2. GROSS BETA ACTIVITY IN AIR (1997)

\begin{tabular}{|c|c|c|c|c|}
\hline \multicolumn{5}{|c|}{ Environmental Science and Research Foundation Data } \\
\hline \multirow[b]{2}{*}{ Group } & \multirow[b]{2}{*}{ Location } & \multirow[b]{2}{*}{$\begin{array}{c}\text { Number of } \\
\text { Samples }\end{array}$} & \multicolumn{2}{|c|}{ Concentration $\left(x 10^{-15} \mu \mathrm{Ci} / \mathrm{mL}\right)$} \\
\hline & & & $\begin{array}{l}\text { Range of } \\
\text { Samples } \\
\end{array}$ & $\begin{array}{r}\text { Annual } \\
\text { Mean }^{2} \\
\end{array}$ \\
\hline \multirow[t]{6}{*}{ Distant } & $\overline{\text { Blackfoot }}$ & 51 & $11-47$ & $\overline{23 \pm 2}$ \\
\hline & Mountain View & 52 & $10-46$ & $23 \pm 2$ \\
\hline & Craters of the Moon & 51 & $9-40$ & $21 \pm 2$ \\
\hline & Idaho Falls & 51 & $9-39$ & $23 \pm 2$ \\
\hline & Rexburg & 51 & $12-47$ & $\underline{26 \pm 2}$ \\
\hline & & & Grand Mean ${ }^{a}$ & $23 \pm 1$ \\
\hline \multirow[t]{8}{*}{ Boundary } & Arco & 52 & $11-47$ & $23 \pm 2$ \\
\hline & Atomic City & 52 & $11-45$ & $24 \pm 2$ \\
\hline & FAA Tower (Replicate) & $51(52)$ & $7-42(8-54)$ & $21 \pm 2(22 \pm 2)$ \\
\hline & Howe & 51 & $7-53$ & $25 \pm 2$ \\
\hline & Monteview (Replicate) & $52(52)$ & $12-48(10-53)$ & $25 \pm 2(25 \pm 3)$ \\
\hline & Mud Lake & 48 & $11-56$ & $25 \pm 3$ \\
\hline & Reno Ranch & 51 & $12-52$ & $\underline{27 \pm 3}$ \\
\hline & & & Grand $\mathrm{Mean}^{a}$ & $24 \pm 1$ \\
\hline \multirow{4}{*}{ INEEL } & EFS & 51 & $9-56$ & $27 \pm 3$ \\
\hline & Main Gate & 52 & $11-54$ & $25 \pm 3$ \\
\hline & Van Buren & 52 & $8-53$ & $\underline{26 \pm 3}$ \\
\hline & & & Grand Mean & $26 \pm 2$ \\
\hline \multicolumn{5}{|c|}{ LMITCO Data } \\
\hline \multirow[b]{2}{*}{ Group } & & & \multicolumn{2}{|c|}{ Concentration $\left(\times 10^{-15} \mu \mathrm{Ci} / \mathrm{mL}\right)$} \\
\hline & Location & $\begin{array}{c}\text { Number of } \\
\text { Samples }\end{array}$ & $\begin{array}{l}\text { Range of } \\
\text { Samples } \\
\end{array}$ & $\begin{array}{r}\text { Annual } \\
\text { Mean }^{2} \\
\end{array}$ \\
\hline \multirow[t]{5}{*}{$\overline{\text { Distant }}$} & Blackfoot & 52 & $7-41$ & $21 \pm 2$ \\
\hline & Craters of the Moon & 52 & $3-32$ & $17 \pm 2$ \\
\hline & Idaho Falls & 52 & $7-42$ & $19 \pm 3$ \\
\hline & Rexburg & 51 & $10-39$ & $\underline{20 \pm 2}$ \\
\hline & & & Grand Mean ${ }^{a}$ & $20 \pm 1$ \\
\hline \multirow[t]{13}{*}{ INEEL } & ANL-W & 47 & $5-46$ & $20 \pm 2$ \\
\hline & ARA & 51 & $6-43$ & $21 \pm 3$ \\
\hline & CFA & 50 & $-2-46$ & $19 \pm 2$ \\
\hline & EBR-1 & 50 & $9-48$ & $22 \pm 2$ \\
\hline & EFS & 49 & $9-48$ & $22 \pm 2$ \\
\hline & INTEC & 48 & $7-44$ & $19 \pm 2$ \\
\hline & NRF & 51 & $8-51$ & $23 \pm 2$ \\
\hline & PBF & 51 & $8-38$ & $22 \pm 2$ \\
\hline & RWMC & 50 & $5-43$ & $18 \pm 2$ \\
\hline & TAN & 51 & $6-38$ & $20 \pm 2$ \\
\hline & TRA & 51 & $7-44$ & $23 \pm 2$ \\
\hline & Van Buren & 50 & $4-40$ & $\underline{20 \pm 2}$ \\
\hline & & & Grand Mean ${ }^{a}$ & $19 \pm 1$ \\
\hline
\end{tabular}



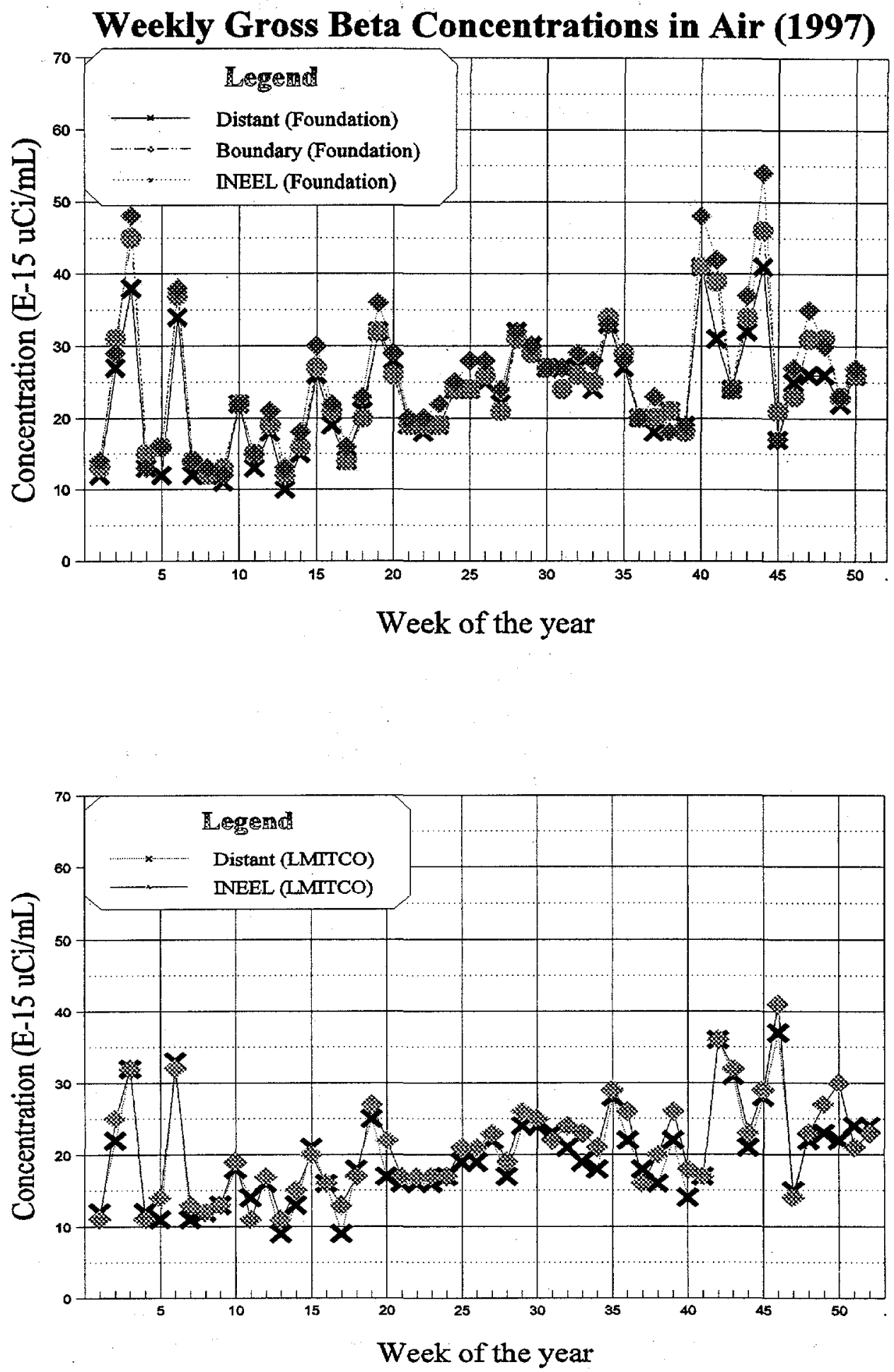

Figure 4-1. Weekly Gross Beta Concentrations in Air (1997) 
Distant vs. Boundary Gross Beta

Concentrations (1988-1992)

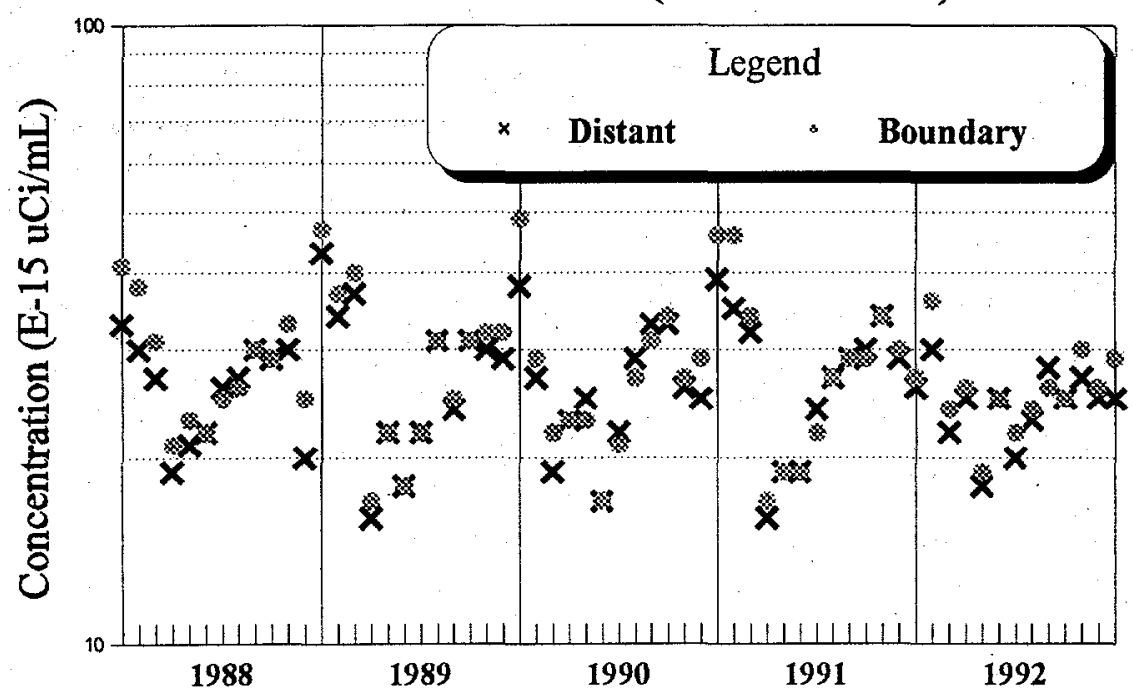

Distant vs. INEEL Gross Beta

Concentrations (1988-1992)

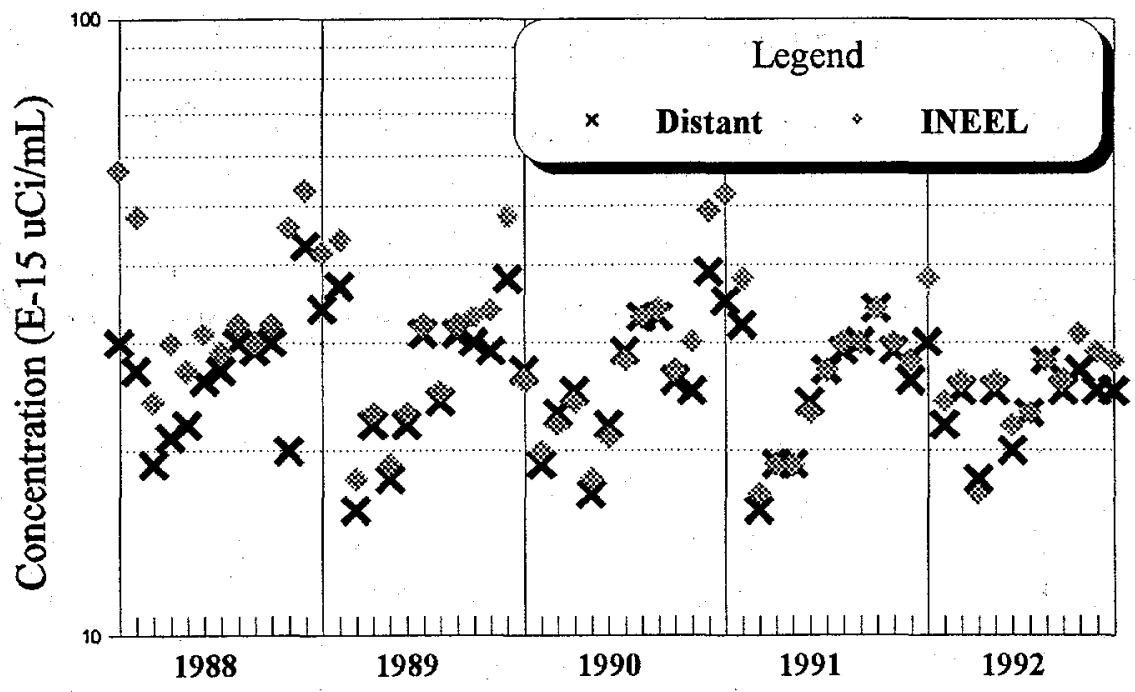

Figure 4-2. Monthly Gross Beta Concentrations (1988-1992) 
Distant vs. Boundary Gross Beta

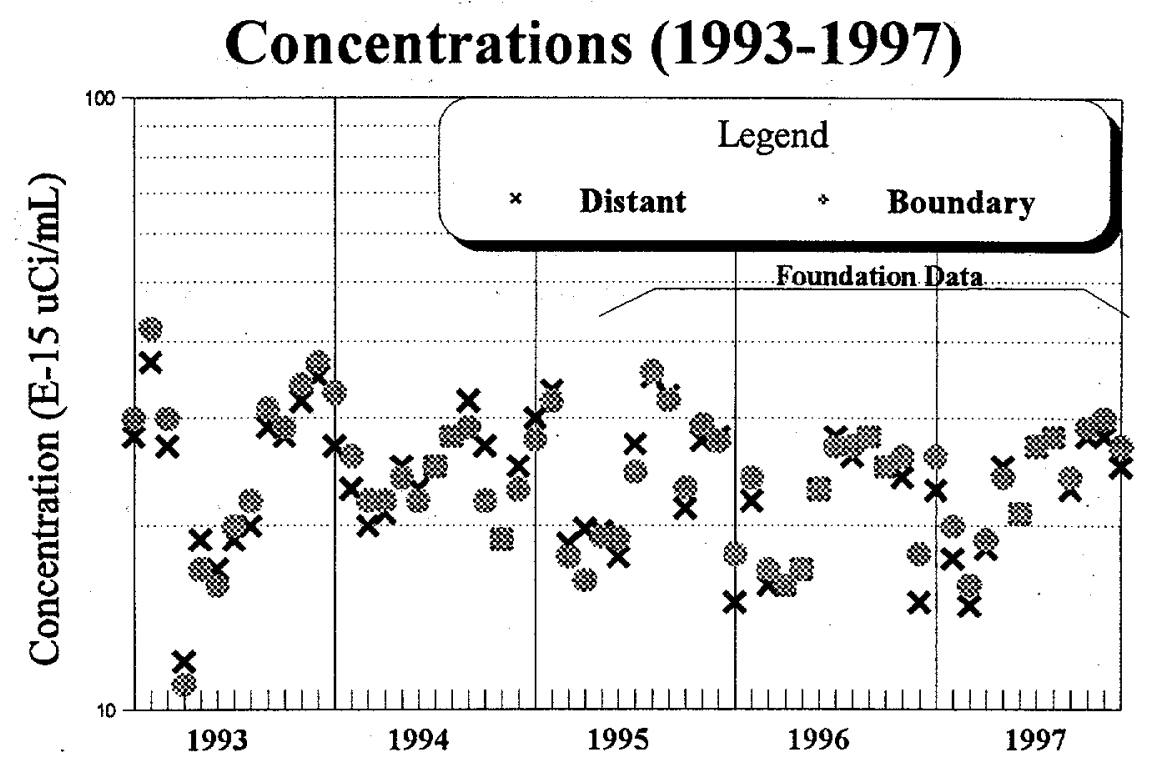

Distant vs. INEEL Gross Beta

\section{Concentrations (1993-1997)}

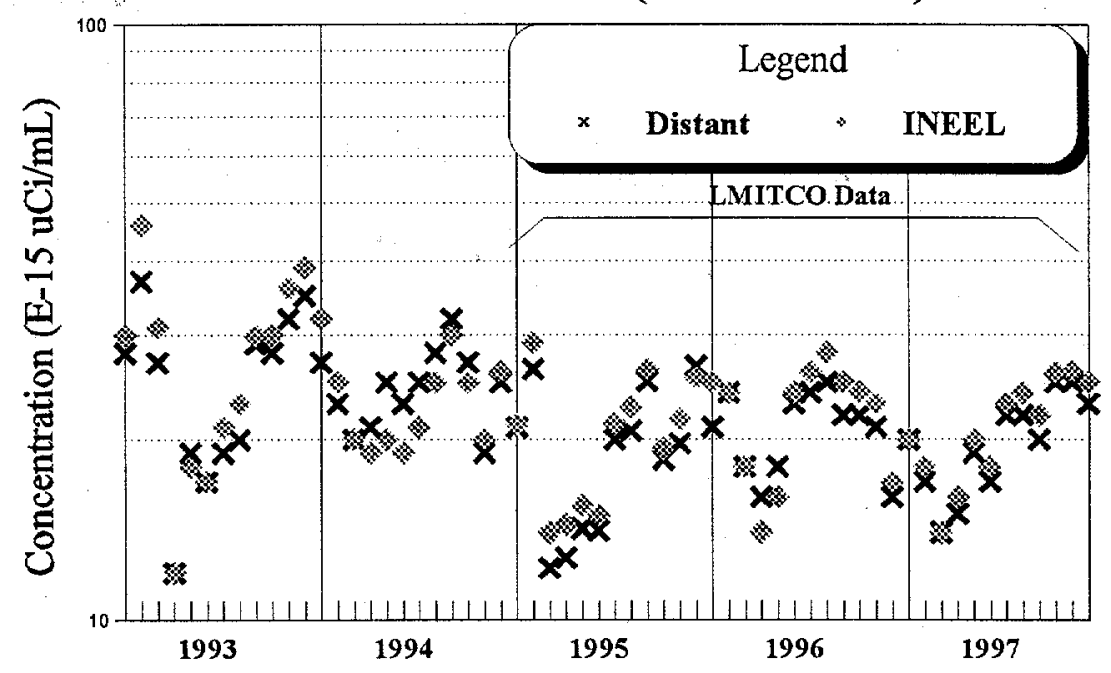

Figure 4-2. (Continued) Monthly Gross Beta Concentrations (1993-1997) 


\begin{tabular}{|c|c|c|c|c|c|c|c|c|c|c|c|c|c|}
\hline STATISTI & AL C & $\begin{array}{l}\text { OMP } \\
\text { ISTA }\end{array}$ & $\begin{array}{l}\text { RISO } \\
\text { NT, B }\end{array}$ & $\begin{array}{l}\text { N TA } \\
\text { DUND }\end{array}$ & $\begin{array}{r}\mathrm{T} \\
\text { 3LE } 0 \\
\text { ARY, }\end{array}$ & $\begin{array}{l}\text { ABLE } \\
\text { F GR } \\
\text { AND }\end{array}$ & $\begin{array}{l}\text { 4-3. } \\
\text { SS B } \\
\text { JEEI }\end{array}$ & LOC & $\begin{array}{l}\text { CNC } \\
\text { ATIO }\end{array}$ & $\begin{array}{l}\text { CNTR } \\
\text { IS (19 }\end{array}$ & $\begin{array}{l}\text { ATIO } \\
7)^{a}\end{array}$ & US IN & $\mathrm{AT}$ \\
\hline \multicolumn{14}{|c|}{ Environmental Science and Research Foundation Data } \\
\hline Location & Jan & Feb & Mar & Apr & May & Jun & Jul & Aug & Sep & Oct & Nov & Dec & Year \\
\hline \multicolumn{14}{|l|}{ Arco } \\
\hline \multicolumn{14}{|l|}{$\begin{array}{l}\text { Atomic City } \\
\text { FAA Tower }\end{array}$} \\
\hline FAA Tower & & & & & & & & & & & & & \\
\hline \multicolumn{14}{|l|}{ Howe } \\
\hline \multicolumn{14}{|l|}{ Monteview } \\
\hline \multicolumn{14}{|l|}{ Mud Lake } \\
\hline \multicolumn{14}{|l|}{ Reno Ranch } \\
\hline \multicolumn{14}{|l|}{ Boundary Group } \\
\hline \multicolumn{14}{|l|}{ EFS } \\
\hline \multicolumn{14}{|l|}{ Main Gate } \\
\hline \multicolumn{14}{|l|}{ Van Buren } \\
\hline \multicolumn{14}{|l|}{ INEEL Group } \\
\hline \multicolumn{14}{|c|}{ LMITCO Data } \\
\hline Location & Jan & Feb & Mar & Apr & May & Jun & Jul & Aug & Sep & Oct & Nov & Dec & Year \\
\hline \multicolumn{14}{|l|}{ ANL-W } \\
\hline ARA & & & & & & & & & 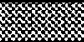 & & & ঋ্যে & \\
\hline CFA & & & & & & & & & & & & & \\
\hline \multicolumn{14}{|l|}{ EBR-1 } \\
\hline \multicolumn{14}{|l|}{ EFS } \\
\hline \multicolumn{14}{|l|}{ INTEC } \\
\hline \multirow{2}{*}{\multicolumn{14}{|c|}{$\begin{array}{l}\text { NRF } \\
\text { PBF }\end{array}$}} \\
\hline & & & & & & & & & & & & & \\
\hline \multicolumn{14}{|l|}{ RWMC } \\
\hline \multicolumn{14}{|l|}{ TAN } \\
\hline \multicolumn{14}{|l|}{ TRA } \\
\hline \multicolumn{14}{|l|}{ Van Buren } \\
\hline INEEL Group & & & & & & & & & & & & & \\
\hline
\end{tabular}

the pattern of fluctuations occurred over the entire sampling network, and therefore were not caused by a localized source such as a facility or activity at the INEEL.

Historic monthly gross beta concentrations for the distant, boundary, and INEEL groups are shown in Figure 4-2. The distant location vs. INEEL graph shows the effects of ${ }^{125} \mathrm{Sb}$, released as one of the effluents of the fuel dissolution process from the Fluorinel Dissolution and Fuel Storage Facility at INTEC during 1987 and the first half of 1988 . The effect is also seen, but to a lesser degree, in the distant vs. boundary graph in Figure 4-2. This indicates the ability of the low-volume air sampling network to detect radioactive airborne releases from the INEEL.

Statistical Comparisons. Statistical comparisons were made between monthly mean gross beta concentrations from each onsite and boundary location and the distant group mean gross beta concentrations. Foundation data indicated statistical differences in three of $36(8 \%)$ 
comparisons involving INEEL locations and two of $84(2 \%)$ comparisons involving boundary locations (Table 4-3). For LMITCO samplers, statistical differences were found in 16 of 144 (11\%) comparisons made for the NEEL locations. Comparisons were also made between the mean gross beta concentration of the boundary group or onsite group and the distant group mean gross beta concentration for each month. For Foundation data, the INEEL group was statistically higher than the distant group during April and June. The boundary group was not statistically higher than the distant group during any month. For LMITCO data, INEEL group gross beta concentrations were only statistically greater than the distant group in August.

Statistical comparisons were made between annual gross beta mean concentrations at individual onsite and boundary locations and the mean annual background gross beta concentration (Table 4-3). For the Foundation, the annual gross beta concentrations for Reno Ranch, EFS, Van Buren, and the INEEL group were statistically greater than the distant mean annual gross beta concentration. For LMITCO, the mean annual gross beta concentrations at EBR-1, EFS, $\mathrm{PBF}, \mathrm{NRF}$, and TRA were statistically greater than the distant mean annual gross beta concentration. The INEEL group as a whole was not statistically greater than background.

Results of the above statistical tests may indicate some of the significant differences are due to INEEL operations at the onsite locations of EBR-1, EFS, and PBF, and offsite at Reno Ranch and Mud Lake. However, gross beta concentrations can vary widely from location to location as a result of a number of factors such as diverse local soil and meteorological conditions. Thus, when statistical differences are found, nuclide analyses discussed in the following section are examined to try to pinpoint the possible specific radionuclide(s) that may have contributed to the elevated concentrations, and to identify a possible INEEL cause, if any, for the differences.

\section{Specific Radionuclides in Air Samples}

Beryllium-7, a naturally-occurring radionuclide produced from cosmic ray interactions, was found in nearly all the quarterly composites analyzed. Anthropogenic radionuclides were observed in Foundation data (Table 4-4), although most were in the range of concentrations where detection is considered questionable (see Appendix B).

Table 4-4 also indicates four relatively high concentrations of ${ }^{90} \mathrm{~S} r$ in Foundation low-volume air samples during the second quarter of 1997. However, the gross beta activities at these locations during the same time period were not significantly higher than other stations in the network, and a quality control blank sample analyzed at the same time also was reported to contain ${ }^{90} \mathrm{Sr}$, making the results questionable.

Since mid-1995, ${ }^{241} \mathrm{Am}$ has been detected by the Foundation several times a year in air samples. No particular location has exhibited ${ }^{241} \mathrm{Am}$ concentrations; detections were scattered across the network. The highest concentrations reported since 1995 occurred at EFS, Arco, Craters of the Moon, Blackfoot, and Monteview. No explanation for these observations has been identified in INEEL operations, and the reported concentrations are not consistent with past measurements of concentrations of ${ }^{241} \mathrm{Am}$ and ${ }^{239 / 240} \mathrm{Pu}$ in soil in southern Idaho. (The reported ratio of ${ }^{241} \mathrm{Am}$ to ${ }^{239 / 240} \mathrm{Pu}$ is too low for the observations to be attributable to wind-blown soil.) The Foundation is currently investigating the possibility that this relatively high incidence of detection is attributable to laboratory errors, but no conclusions have yet been made. No positive detections of specific man-made radionuclides were reported by LMITCO

\section{Atmospheric Moisture}

During 1997, 26 atmospheric moisture samples were collected by the Foundation from Atomic City, Mountain View, Idaho Falls, and Rexburg. Tritium was detected in seven of the 


\begin{tabular}{|c|c|c|c|c|c|c|}
\hline \multirow{14}{*}{$\frac{\text { Radionuclide }}{{ }^{90} \mathrm{Sr}}$} & $\begin{array}{c}\text { Calendar } \\
\text { Quarter }\end{array}$ & $\begin{array}{l}\text { INEEL } \\
\text { Location }\end{array}$ & $\begin{array}{c}\text { Boundary } \\
\text { Location }\end{array}$ & $\begin{array}{c}\text { Distant } \\
\text { Location }\end{array}$ & $\begin{array}{c}\text { Concentration } \pm 2 \mathrm{~s} \\
\left(\mathrm{x} 10^{-15} \mu \mathrm{Ci} / \mathrm{mL}\right)\end{array}$ & $\begin{array}{c}\mathrm{DCG}^{\mathrm{a}} \\
\left(\mathrm{x} 10^{-15} \mu \mathrm{Ci} / \mathrm{mL}\right)\end{array}$ \\
\hline & First & & $\overline{\text { Atomic City }}$ & & $0.06 \pm 0.05$ & 9,000 \\
\hline & First & & $\begin{array}{l}\text { FAA Tower } \\
\text { Replicate }\end{array}$ & & $\begin{array}{c}0.06 \pm 0.05 \\
\text { Not Detected }\end{array}$ & \\
\hline & First & $\mathrm{EFS}$ & & & $0.10 \pm 0.06$ & \\
\hline & Second & & & Mtn. View & $0.20 \pm 0.06^{b}$ & \\
\hline & Second & & & Rexburg & $0.20 \pm 0.06^{b}$ & \\
\hline & Second & & Arco & & $0.20 \pm 0.06^{b}$ & \\
\hline & Second & & Monteview & & $0.30 \pm 0.06^{b}$ & \\
\hline & & & Replicate & & $0.10 \pm 0.06^{b}$ & \\
\hline & Second & Main Gate & & & $0.10 \pm 0.06^{b}$ & \\
\hline & Third & & & Blackfoot & $0.10 \pm 0.09$ & \\
\hline & Fourth & & Mud Lake & & $0.04 \pm 0.03$ & \\
\hline & Fourth & & Atomic City & & $0.03 \pm 0.03$ & \\
\hline & Fourth & & FAA Tower & & $0.09 \pm 0.04$ & \\
\hline \multirow[t]{20}{*}{${ }^{241} \mathrm{Am}$} & First & & Arco & & $0.006 \pm 0.003$ & 20 \\
\hline & First & & & Blackfoot & $0.009 \pm 0.003$ & \\
\hline & First & & & Craters & $0.009 \pm 0.003$ & \\
\hline & First & & Monteview & & $0.008 \pm 0.003$ & \\
\hline & & & Replicate & & $0.006 \pm 0.003$ & \\
\hline & First & Main Gate & & & $0.005 \pm 0.002$ & \\
\hline & Second & & & Mtn. View & $0.003 \pm 0.002$ & \\
\hline & Third & & & Craters & $0.005 \pm 0.003$ & \\
\hline & Third & & Mud Lake & & $0.005 \pm 0.003$ & \\
\hline & Third & & Reno Ranch & & $0.002 \pm 0.001$ & \\
\hline & Third & & & Mtn.View & $0.004 \pm 0.002$ & \\
\hline & Third & EFS & & & $0.004 \pm 0.002$ & \\
\hline & Third & & FAA Tower & & Not Detected & \\
\hline & & & Replicate & & $0.004 \pm 0.002$ & \\
\hline & Fourth & & & Craters & $0.003 \pm 0.002$ & \\
\hline & Fourth & & & Blackfoot & $0.004 \pm 0.001$ & \\
\hline & Fourth & & Arco & & $0.002 \pm 0.001$ & \\
\hline & Fourth & & Monteview & & $0.002 \pm 0.001$ & \\
\hline & & & Replicate & & Not Detected & \\
\hline & Fourth & Main Gate & & & $0.003 \pm 0.002$ & \\
\hline $239 / 240 \mathrm{Pu}$ & Fourth & & Arco & & $0.002 \pm 0.001$ & 20 \\
\hline
\end{tabular}

samples. During the first quarter, Atomic City, Blackfoot, and Idaho Falls samples showed concentrations of $(1.3 \pm 0.9) \times 10^{-13} \mu \mathrm{Ci} / \mathrm{mL}$, $(0.5 \pm 0.4) \times 10^{-13} \mu \mathrm{Ci} / \mathrm{mL}$, and $(1.9 \pm 0.9) \times 10^{-13} \mu \mathrm{Ci} / \mathrm{mL}$, respectively. For the second quarter, an Idaho Falls sample had a concentration of $(1.0 \pm 0.3) \times 10^{-13} \mu \mathrm{Ci} / \mathrm{mL}$ and an Atomic City sample had a concentration of $(0.8 \pm$ $0.4) \times 10^{-13} \mu \mathrm{Ci} / \mathrm{mL}$. During the third quarter, a sample from Idaho Falls contained a concentration of $(5.6 \pm 2.2) \times 10^{-13} \mu \mathrm{Ci} / \mathrm{mL}$ and a sample from Atomic City had a concentration of (2.7 \pm 1.4) $\times 10^{-13} \mu \mathrm{Ci} / \mathrm{mL}$. No samples taken during the fourth quarter contained detectable tritium concentrations. Because these detected concentrations were all very low, and because concentrations were similar at distant, boundary, and onsite locations, they are probably attributable 
to natural production of tritium in the atmosphere by cosmic ray bombardment, from residual weapons testing fallout, and possible analytical variations rather than to INEEL operations. The highest observed concentration (from Idaho Falls) represents approximately $0.0006 \%$ of the derived concentration guide.

LMITCO also collected atmospheric moisture samples at the EFS and at Van Buren on the INEEL: At each location LMITCO collected from one to three samples each quarter. Preliminary laboratory analyses indicated that some samples may have contained detectable concentrations of tritium, but uncertainties in both sampling and laboratory analyses make these detections questionable. LMITCO is investigating these detections but had reached no conclusions at the time of this report.

\section{Precipitation}

When available, precipitation samples were collected weekly onsite at the EFS and monthly onsite at the CFA and offsite in Idaho Falls. A total of 37 precipitation samples were collected during 1997. Tritium was detected in eight of the samples at concentrations ranging from $(1.2 \pm 1.0) \times 10^{-7} \mu \mathrm{Ci} / \mathrm{mL}$ to $(1.9 \pm 1.0) \times 10^{-7}$ $\mu \mathrm{Ci} / \mathrm{mL}$. The highest concentration was shared by three samples, all from EFS. However, tritium was detected in at least one sample from each of the three sites during the year. Concentrations such as these are well within the normal range observed in recent years and are likely due to the worldwide inventory of tritium from natural production of tritium in the upper atmosphere and expected variability in laboratory analyses, as well as small residual quantities from nuclear weapons testing.

\subsection{WATER}

This section presents results from radiological analyses performed on drinking water and surface water samples taken at offsite locations by the Environmental Science and Research
Foundation. In addition, results of LMITCO's storm water monitoring results are presented. Radiological results from onsite production well sampling may be found in Chapter 6, "Ground Water," with results from additional sampling conducted by the LMITCO Drinking Water Program.

\section{Offsite Water Sampling}

Gross Alpha. In 1997, the Foundation collected 50 offsite water samples, 18 from surface water locations and 32 from drinking water locations. No samples contained detectable concentrations of gross alpha.

Gross Beta. Gross beta activity above the minimum detectable concentration was present in 41 of the 50 offsite water samples. Detectable concentrations ranged from $(3.0 \pm 2.0) \times 10^{-9}$ $\mu \mathrm{Ci} / \mathrm{mL}$ to $(10 \pm 3) \times 10^{-9} \mu \mathrm{Ci} / \mathrm{mL}$. The upper value of this range is $20 \%$ of the EPA MCL for drinking water. Concentrations in this range are usual and are attributed to natural decay processes of thorium and uranium which is sorbed into the water as it passes through the earth's crust.

Tritium. Tritium was detected in one offsite drinking water sample taken from Shoshone at a concentration of $(90 \pm 80) \times 10^{-9} \mu \mathrm{Ci} / \mathrm{mL}$. This concentration is $0.5 \%$ of the EPA MCL for tritium in drinking water.

\section{Storm Water Sampling}

During 1997, 13 storm water samples were analyzed for gross alpha, gross beta, ${ }^{89} \mathrm{Sr},{ }^{234} \mathrm{U}$, ${ }^{241} \mathrm{Am}$, and ${ }^{239} \mathrm{Pu}$. Benchmarks have been established for radionuclides in storm water runoff at the INEEL, based on the Derived Concentration Guides in DOE Order 5400.5. One sample, taken from the RWMC, had a gross alpha concentration of $30 \pm 4 \mathrm{pCi} / \mathrm{L}$, equal to the corresponding benchmark. No other samples contained detectable concentrations of radionuclides of interest. 


\begin{tabular}{|c|c|c|c|c|c|}
\hline \multicolumn{6}{|c|}{$\begin{array}{c}\text { TABLE 4-5. STRONTIUM-90 CONCENTRATIONS } \\
\text { IN GARDEN LETTUCE (1993-1997) }\end{array}$} \\
\hline \multirow[b]{2}{*}{ Sample Location } & \multicolumn{5}{|c|}{${ }^{90} \mathrm{Sr}$ Concentration $\left(10^{-9} \mu \mathrm{Ci} / \mathrm{g} \text { dry weight }\right)^{a}$} \\
\hline & 1993 & $\underline{1994}$ & $\underline{1995}$ & 1996 & 1997 \\
\hline \multicolumn{6}{|l|}{ Distant Group: } \\
\hline Blackfoot & $-30 \pm 60$ & $160 \pm 80$ & $740 \pm 200$ & $270 \pm 240^{\mathrm{e}}$ & $90 \pm 70$ \\
\hline Carey & $-70 \pm 50$ & $130 \pm 40$ & $-50 \pm 180$ & - & $70 \pm 50$ \\
\hline Idaho Falls & $-80 \pm 50$ & $120 \pm 40$ & $60 \pm 30$ & --- & $50 \pm 30$ \\
\hline \multirow[t]{2}{*}{ Pocatello } & $180 \pm 140$ & $\ldots$ & -.-- & $\ldots$ & $40 \pm 60$ \\
\hline & $0 \pm 190$ & $140 \pm 50$ & $250 \pm 1050$ & $270 \pm \ldots f$ & $\overline{60 \pm 40}$ \\
\hline \multicolumn{6}{|l|}{ Boundary Group: } \\
\hline Arco & $90 \pm 90$ & $50 \pm 40$ & $140 \pm 50$ & $200 \pm 200^{e}$ & $70 \pm 70$ \\
\hline Atomic City & $-80 \pm 60$ & $200 \pm 60$ & $300 \pm 120$ & $120 \pm 100$ & $160 \pm 60$ \\
\hline Howe & $N S^{d}$ & NS & NS & $100 \pm 160$ & $80 \pm 80$ \\
\hline Monteview & $210 \pm 80$ & $110 \pm 40$ & $100 \pm 90$ & NS & $90 \pm 40$ \\
\hline Mud Lake/Terreton & $\underline{40 \pm 70}$ & $\underline{70 \pm 60}$ & $\underline{80 \pm 40}$ & $160 \pm 360^{\circ}$ & $170 \pm 80$ \\
\hline $\operatorname{Mean}^{c}$ & $\overline{70 \pm 190}$ & $\overline{10 \pm 100}$ & $\overline{160 \pm 160}$ & $140 \pm 70$ & $\overline{130 \pm 60}$ \\
\hline \multicolumn{6}{|c|}{$\begin{array}{l}\text { Analytical results } \pm 2 \mathrm{~s} \text {. Approximate minimum detectable concentration of }{ }^{00} \mathrm{Sr} \text { in lettuce is } 80 \times 10^{-9} \mu \mathrm{Ci} / \mathrm{g} \text { dry weight. } \\
\text { - Sample destroyed in preparation or analysis. } \\
\text { Arithmetic mean with the } 95 \% \text { confidence interval for the mean. } \\
\text { i No sample was collected at this location during the year. } \\
\text { Low chemical yield }(<20 \%) \text {. } \\
95 \% \text { confidence interval cannot be determined for only one sample. }\end{array}$} \\
\hline
\end{tabular}

More detailed information and data on storm water monitoring will be included in the 1997 Compliance Monitoring Annual Report, INEEL-97/0255(97), due to be published in August 1998.

\subsection{FOODSTUFFS}

Milk. During 1997, 151 milk samples were collected. All of the samples were analyzed for ${ }^{131}$ I. During the first and third quarters, selected samples were analyzed for tritium. During the second and fourth quarters, selected samples were analyzed for ${ }^{90} \mathrm{Sr}$.

Analyses indicated ${ }^{131} \mathrm{I}$ in one sample from Idaho Falls at a concentration of $(1.9 \pm 1.6) \times 10^{9} \mu \mathrm{Ci} / \mathrm{mL}$ and one sample from Arco at a concentration of $(2.4 \pm 2.3) \times 10^{-9}$ $\mu \mathrm{Ci} / \mathrm{mL}$, both during the third quarter. Both results were just above the minimum detectable concentration. Tritium was not detected in any 1997 milk samples. Strontium-90 was detected in seven samples ranging from $(0.6 \pm 0.3) \times 10^{-9}$ $\mu \mathrm{Ci} / \mathrm{mL}$ at Idaho Falls to $(1.4 \pm 0.3) \times 10^{-9}$ $\mu \mathrm{Ci} / \mathrm{mL}$ in a sample from Blackfoot. All levels of ${ }^{90} \mathrm{Sr}$ in milk were consistent with those previously reported by the EPA as resulting from worldwide fallout deposited on soil, then taken up by ingestion of grass by cows [Reference 4-1].

Lettuce. Nine lettuce samples, including one duplicate, were collected from regional private gardens. Cesium-137 was detected in samples from Atomic City and Monteview at concentrations of $(1.2 \pm 0.5) \times 10^{-7} \mu \mathrm{Ci} / \mathrm{g}$ and $(2.8 \pm 0.8) \times 10^{-7} \mu \mathrm{Ci} / \mathrm{g}$, respectively. Strontium90 was detected in six of the lettuce samples (Table 4-5). Both ${ }^{137} \mathrm{Cs}$ and ${ }^{90} \mathrm{Sr}$ are present in soil from above-ground nuclear weapons testing which took place primarily in the 1950s and 1960s. 


\begin{tabular}{|c|c|c|c|c|c|c|}
\hline \multicolumn{7}{|c|}{ TABLE 4-6. STRONTIUM-90 CONCENTRATIONS IN WHEAT (1993-1997) } \\
\hline \multirow[b]{2}{*}{ Sample Location } & & \multicolumn{5}{|c|}{${ }^{90} \mathrm{Sr}$ Concentration $\left(10^{-9} \mu \mathrm{Ci} / \mathrm{g} \text { dry weight }\right)^{a}$} \\
\hline & & $\underline{1993}$ & 1994 & 1995 & $\underline{1996}$ & 1997 \\
\hline \multicolumn{7}{|l|}{ Distant Group: } \\
\hline American Falls & & $2 \pm 2$ & $7 \pm 2$ & $8 \pm 4$ & $7 \pm 5$ & $9 \pm 5$ \\
\hline Blackfoot & & $2 \pm 4$ & $7 \pm 2$ & $4 \pm 4$ & $6 \pm 6$ & $14 \pm 6$ \\
\hline Carey & & $2 \pm 4$ & $2 \pm 2$ & $11 \pm 7$ & $5 \pm 6$ & $5 \pm 4$ \\
\hline Dietrich & & $-1 \pm 4$ & $3 \pm 2$ & NS & $5 \pm 5$ & $4 \pm 4$ \\
\hline Idaho Falls & & $0 \pm 3$ & $6 \pm 2$ & $9 \pm 5$ & $9 \pm 18^{\mathrm{d}}$ & $4 \pm 4$ \\
\hline Minidoka & & $4 \pm 4$ & $\underline{6 \pm 2}$ & $3 \pm 5$ & $8 \pm 5$ & $5 \pm 4$ \\
\hline & $\operatorname{Mean}^{c}$ & $2 \pm 2$ & $5 \pm 2$ & $\overline{7 \pm 4}$ & $7 \pm 2$ & $\overline{7 \pm 4}$ \\
\hline \multicolumn{7}{|l|}{ Boundary Group: } \\
\hline Arco & & $-1 \pm 3$ & $4 \pm 2$ & $3 \pm 5$ & $16 \pm 40^{d}$ & $4 \pm 3$ \\
\hline Monteview & & $1 \pm 4$ & $7 \pm 3$ & $4 \pm 4$ & $3 \pm 4$ & $5 \pm 5$ \\
\hline Mud Lake & & $2 \pm 4$ & $5 \pm 2$ & $4 \pm 5$ & $5 \pm 5$ & $4 \pm 4$ \\
\hline Tabor & & $0 \pm 6$ & $8 \pm 2$ & $12 \pm 6$ & $10 \pm 6$ & $5 \pm 5$ \\
\hline \multirow[t]{2}{*}{ Terreton } & & $1 \pm 2$ & $5 \pm 2$ & $7 \pm 5$ & $8 \pm 6$ & $6 \pm 4$ \\
\hline & $M_{e a n^{c}}$ & $1 \pm 1$ & $6 \pm 2$ & $6 \pm 5$ & $8 \pm 6$ & $\overline{5 \pm 1}$ \\
\hline $\begin{array}{ll}\text { Analytical results }+2 \mathrm{~s} . \\
\text { b } & \text { No sample was collected } \\
\text { c } & \text { Arithmetic mean with the } \\
\text { d } & \text { Low chemical yield }(<20\end{array}$ & $\begin{array}{l}\text { ximate } m \\
\text { s location } \\
\text { confiden }\end{array}$ & $\begin{array}{l}\text { um detecta } \\
\text { ng the yea } \\
\text { terval for } t\end{array}$ & tration of & it is $4 \times 1$ & y weight. & \\
\hline
\end{tabular}

Wheat. Of the 11 wheat samples collected during 1997, one sample from Idaho Falls was reported to contain ${ }^{137} \mathrm{Cs}$ at a concentration of $(2.7 \pm 2.5) \times 10^{-6} \mu \mathrm{Ci} / \mathrm{g}$. However, this value is barely in the detectable range and is probably due to normal statistical fluctuations in radiometric analysis. No ${ }^{137} \mathrm{Cs}$ has been detected in wheat samples in recent years. Measurable concentrations of ${ }^{90} \mathrm{Sr}$ were seen in six samples from both distant and boundary locations (Table 4-6). The concentrations of ${ }^{90} \mathrm{Sr}$ were similar to those detected in recent years, and are attributed to historic above-ground nuclear weapons testing during the 1950s and 1960s.

Potatoes. Seven potato samples were collected during 1997, four from distant locations and three from boundary locations. Strontium-90 was detected in the sample from Mud Lake at a concentration of $(5.3 \pm 4.0) \times 10^{-9} \mu \mathrm{Ci} / \mathrm{g}$ and in the sample from Arco at a concentration of
$(5.3 \pm 4.2) \times 10^{-9} \mu \mathrm{Ci} / \mathrm{g}$. These concentrations are consistent with past results seen in potatoes, wheat, and lettuce.

Sheep. Ten sheep were sampled during the second and fourth quarters of 1997. Six were taken from INEEL land, and four were taken from St. Anthony and Blackfoot to serve as control samples. Cesium-137 was detected in the muscle tissue of three of the control samples ranging from $(3.2 \pm 3.1) \times 10^{-9} \mu \mathrm{Ci} / \mathrm{g}$ to $(5.9 \pm 2.4) \times 10^{-9} \mu \mathrm{Ci} / \mathrm{g}$. It was also detected in livers of two control samples at concentrations of $(2.7 \pm 1.8)$ and $(5.1 \pm 3.2) \times 10^{-9} \mu \mathrm{Ci} / \mathrm{g}$. For samples taken onsite, ${ }^{137} \mathrm{Cs}$ was detected in the muscle tissue of two sheep at concentrations of $(3.8 \pm 2.8)$ and $(6.7 \pm 2.8) \times 10^{-9} \mu \mathrm{Ci} / \mathrm{g}$. It was also detected in the livers of two onsite sheep at concentrations of $(3.9 \pm 3.3)$ and $(6.0 \pm 3.6) \times 10^{-9} \mu \mathrm{Ci} / \mathrm{g}$. All ${ }^{137} \mathrm{Cs}$ concentrations were similar to those found in both onsite and offsite sheep samples during recent years. Iodine-131 was not detected in any of the sheep 


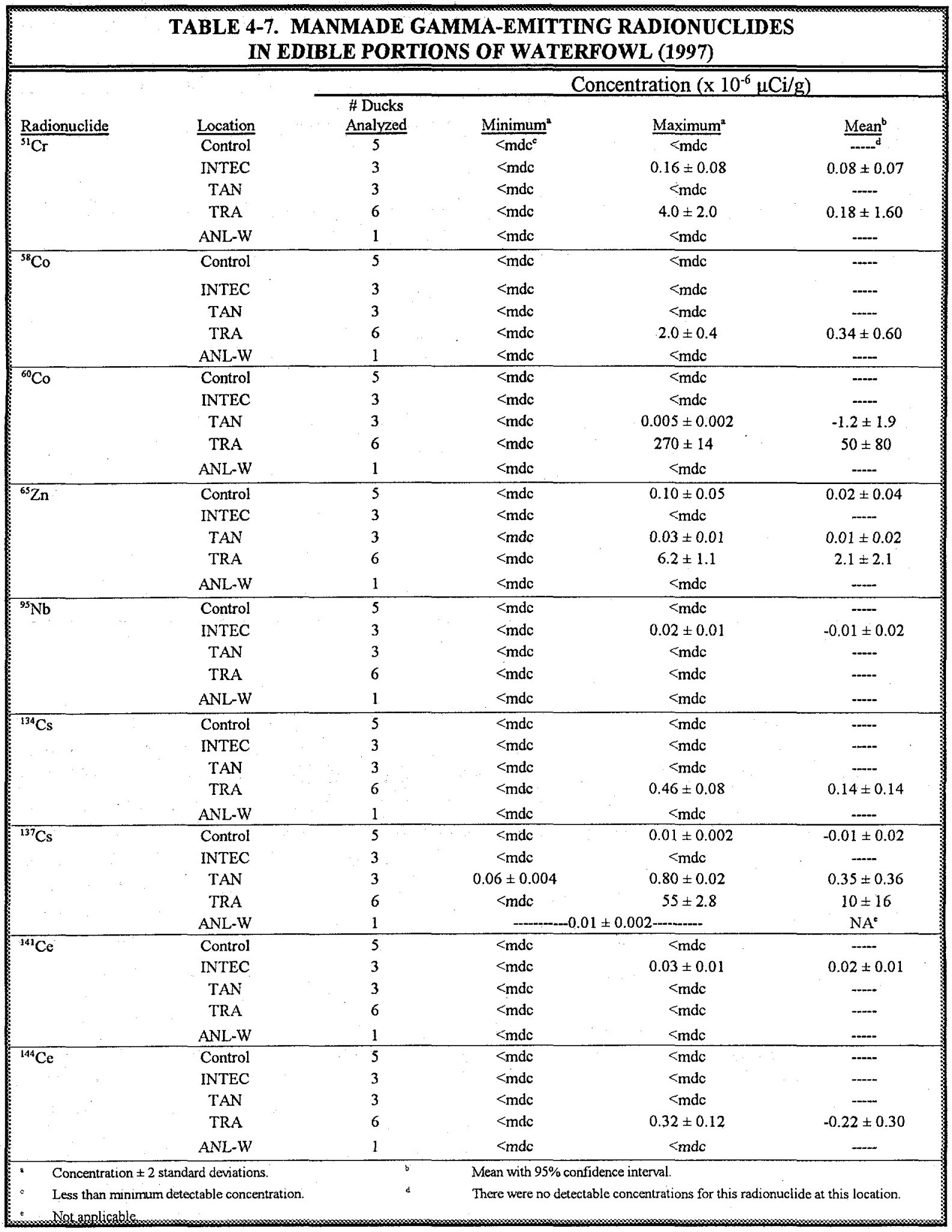


TABLE 4-8. STRONTIUM-90 AND TRANSURANICS IN EDIBLE PORTIONS OF WATERFOWL (1997)

\begin{tabular}{|c|c|c|c|c|c|}
\hline \multirow{7}{*}{$\frac{\text { Radionuclide }}{{ }^{90} \mathrm{Sr}}$} & \multirow{7}{*}{$\begin{array}{l}\text { Location } \\
\text { Control } \\
\text { INTEC } \\
\text { TAN } \\
\text { TRA } \\
\text { ANL-W }\end{array}$} & \multirow[b]{2}{*}{$\begin{array}{l}\text { \# Ducks } \\
\text { Analyzed }\end{array}$} & \multicolumn{3}{|c|}{ Concentration $\left(\times 10^{-6} \mu \mathrm{Ci} / \mathrm{g}\right)$} \\
\hline & & & \multirow{6}{*}{$\begin{array}{c}{\frac{\text { Minimum }^{\mathrm{a}}}{}}_{\mathrm{<mdc}^{\mathrm{m}}}<\mathrm{mdc} \\
<\mathrm{mdc} \\
0.08 \pm 0.03 \\
<\mathrm{mdc}\end{array}$} & \multirow{6}{*}{$\begin{array}{c}\frac{\text { Maximum }^{\mathrm{a}}}{0.07 \pm 0.03} \\
\quad<\mathrm{mdc} \\
<\mathrm{mdc} \\
1.76 \pm 0.17 \\
<\mathrm{mde}\end{array}$} & \multirow{6}{*}{$\begin{array}{c}\underline{\text { Mean }}^{b} \\
0.03 \pm 0.03 \\
\cdots \\
0.92 \pm 1.16 \\
\cdots\end{array}$} \\
\hline & & 4 & & & \\
\hline & & 2 & & & \\
\hline & & 1 & & & \\
\hline & & 2 & & & \\
\hline & & 1 & & & \\
\hline \multirow[t]{5}{*}{${ }^{238} \mathrm{Pu}$} & Control & 4 & $<\mathrm{mdc}$ & $<\mathrm{mdc}$ & $\ldots$ \\
\hline & INTEC & 2 & $<\mathrm{mdc}$ & $<$ mde & $\ldots$ \\
\hline & TAN & 1 & $<\mathrm{mdc}$ & $<\mathrm{mdc}$ & ...... \\
\hline & TRA & 2 & $<\mathrm{mdc}$ & $<\mathrm{mdc}$ & -.-.- \\
\hline & ANL-W & 1 & $<\mathrm{mdc}$ & $<\mathrm{mdc}$ & $-\cdots$ \\
\hline \multirow[t]{5}{*}{${ }^{239 i 240} \mathrm{Pu}$} & Control & 4 &.$<\mathrm{mdc}$ & $<\mathrm{mdc}$ & $\bar{\cdots}$ \\
\hline & INTEC & 2 & $<\mathrm{mdc}$ & $<\mathrm{mdc}$ & --.-- \\
\hline & TAN & 1 & $<\mathrm{mdc}$ & $<\mathrm{mdc}$ & $\ldots$ \\
\hline & TRA & 2 & $<\mathrm{mdc}$ & $<\mathrm{mdc}$ & $\ldots$ \\
\hline & ANL-W & 1 & $\leq \mathrm{mdc}$ & $<\mathrm{mde}$ & $\ldots$ \\
\hline \multirow[t]{5}{*}{${ }^{241} \mathrm{Am}$} & Control & 4 & $<\mathrm{mdc}$ & $<$ mde & -..- \\
\hline & INTEC & 2 & $<\mathrm{mdc}$ & $0.006 \pm 0.003$ & $0.004 \pm 0.003$ \\
\hline & TAN & 1 & $<\mathrm{mdc}$ & $<\mathrm{mdc}$ & $-\ldots$ \\
\hline & TRA & 2 & $<\mathrm{mdc}$ & $0.002 \pm 0.002$ & $0.002 \pm 0.001$ \\
\hline & ANL-W & 1 & $<\mathrm{mdc}$ & $<\mathrm{mdc}$ & --- \\
\hline \multicolumn{6}{|c|}{$\begin{array}{l}\text { Concentration } \pm 2 \text { standard deviations. } \\
\text { Mean with } 95 \% \text { confidence interval. } \\
\text { d There were no detectable concentrations for this radionuclide at this location. } \\
\text { Na confidence interval is calculated with one sample. }\end{array}$} \\
\hline
\end{tabular}

thyroid gland samples. The presence of ${ }^{137} \mathrm{Cs}$ is attributed to the world-wide inventory of fallout from historic nuclear weapons testing.

Game Animals. Two mule deer and two pronghorn, which had been accidentally killed on INEEL roads, were sampled. One pronghorn hit on Highway 20 had detectable ${ }^{137} \mathrm{Cs}$ in the muscle at a concentration of $(3.8 \pm 2.8) \times 10^{-9}$ $\mu \mathrm{Ci} / \mathrm{g}$. Another pronghorn sampled during the third quarter had ${ }^{137} \mathrm{Cs}$ in the muscle tissue at a concentration of $(6.8 \pm 3.3) \times 10^{-9} \mu \mathrm{Ci} / \mathrm{g}$. These concentrations are within the usual range observed in both onsite and offsite sheep samples. No ${ }^{131}$ I was detected in any of the thyroid glands.

A total of 18 ducks were taken during 1997 from the following areas: five control ducks from the Little Lost River and the south fork of the Snake River, six from the radioactive waste ponds at the Test Reactor Area (TRA), three from historic radioactive waste ponds at the Idaho Nuclear Technology and Engineering Center (INTEC), three from the Technical Support Facility (TSF) ponds at Test Area North (TAN), and one from the ponds at Argonne National Laboratories-West (ANL-W). Detectable concentrations of a variety of manmade gammaemitting radionuclides, ${ }^{90} \mathrm{Sr}$, and transuranics were measured in the edible portions of ducks collected from the TRA, INTEC, and TAN ponds (Tables 4-7 and 4-8). Control ducks had measurable concentrations of some of the radionuclides, but generally at levels close to the minimum detectable concentrations. The highest concentrations, as expected, were seen in waterfowl from the TRA ponds. Some of the radionuclides $\left({ }^{51} \mathrm{Cr}\right.$, ${ }^{95} \mathrm{Nb}$, and $\left.{ }^{141} \mathrm{Ce}\right)$ listed in Table 4-7 as being found in ducks sampled at INTEC are short-leved and unlikely to have been released at INTEC. Waterfowl on the INEEL move 


\begin{tabular}{|c|c|c|c|c|c|}
\hline \multirow{5}{*}{$\frac{\text { Radionuclide }}{{ }^{54} \mathrm{Mn}}$} & \multirow{5}{*}{$\begin{array}{l}\frac{\text { Location }}{\text { Control }^{c}} \\
\text { INTEC } \\
\text { TRA }\end{array}$} & \multicolumn{4}{|c|}{ Concentration $\left(\times 10^{-6} \mu \mathrm{Ci} / \mathrm{g}\right)$} \\
\hline & & $\begin{array}{l}\text { \# Doves } \\
\text { Analyzed }\end{array}$ & Minimum $^{3}$ & Maximum $^{\mathbf{a}}$ & Mean ${ }^{b}$ \\
\hline & & $\frac{201000}{4}$ & $<m d c^{d}$ & $<\mathrm{mdc}$ & 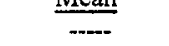 \\
\hline & & 3 & $<\mathrm{mdc}$ & $<\mathrm{mdc}$ & - \\
\hline & & 4 & $<\mathrm{mdc}$ & $0.11 \pm 0.08$ & $0.06 \pm 0.04$ \\
\hline \multirow[t]{3}{*}{${ }^{95} \mathrm{Nb}$} & Control & 4 & $<\operatorname{mdc}$ & $0.16 \pm 0.09$ & $0.03 \pm 0.11$ \\
\hline & INTEC & 3 & $<\mathrm{mdc}$ & $0.33 \pm 0.28$ & $0.17 \pm 0.19$ \\
\hline & TRA & 4 & $<$ mdc & $0.35 \pm 0.26$ & $0.01 \pm 0.22$ \\
\hline \multirow[t]{3}{*}{${ }^{99} \mathrm{Zr}$} & Control & 4 & $<\mathrm{mdc}$ & $0.17 \pm 0.16$ & $0.02 \pm 0.16$ \\
\hline & INTEC & 3 & $<\mathrm{mdc}$ & $<$ mde & $-\cdots$ \\
\hline & TRA & 4 & $<\mathrm{mdc}$ & $0.41 \pm 0.23$ & $0.13 \pm 0.21$ \\
\hline \multirow[t]{3}{*}{${ }^{124} \mathrm{Sb}$} & Control & 4 & $<\mathrm{mdc}$ & $<\mathrm{mdc}$ & $\ldots$ \\
\hline & INTEC & 3 & $<\mathrm{mdc}$ & $0.22 \pm 0.13$ & $-0.02 \pm 0.20$ \\
\hline & TRA & 4 & $<\mathrm{mdc}$ & $0.18 \pm 0.16$ & $0.03 \pm 0.11$ \\
\hline \multirow[t]{3}{*}{${ }^{140} \mathrm{Ba}$} & Control & 4 & $<\mathrm{mdc}$ & $1.4 \pm 0.5$ & $0.6 \pm 0.7$ \\
\hline & INTEC & 3 & $<\mathrm{mdc}$ & $23.3 \pm 12.0$ & $9.9 \pm 14.0$ \\
\hline & TRA & 4 & $<\mathrm{mdc}$ & $62.2 \pm 25.8$ & $23.9 \pm 22.0$ \\
\hline \multirow[t]{3}{*}{${ }^{238} \mathrm{Pu}$} & Control & 3 & $<\mathrm{mdc}$ & $<\mathrm{mdc}$ & $\ldots$ \\
\hline & INTEC & 1 & $<\mathrm{mdc}$ & \multicolumn{2}{|c|}{$0.008 \pm 0.007$} \\
\hline & TRA & 2 & $<\mathrm{mdc}$ & $<\mathrm{mdc}$ & $\cdots$ \\
\hline \multirow[t]{3}{*}{${ }^{241} \mathrm{Am}$} & Control & 3 & $<\mathrm{mdc}$ & $<\mathrm{mdc}$ & $m$ \\
\hline & INTEC & 1 & $<\mathrm{mdc}$ & $<\mathrm{mdc}$ & $-\cdots$ \\
\hline & TRA & 2 & $<\mathrm{mdc}$ & $0.033 \pm 0.012$ & $0.016 \pm 0.023$ \\
\hline \multicolumn{3}{|c|}{$\begin{array}{l}\text { Concentration } \pm 2 \text { standard deviations. } \\
\text { Mean with } 95 \% \text { confidence interval. } \\
\text { Control sample data from doves collected in } 1996 .\end{array}$} & . & & \\
\hline \multicolumn{3}{|c|}{ Less than minimum detectable concentration. } & & & \\
\hline
\end{tabular}

frequently between the available bodies of water and are likely to have spent time at the TRA ponds.

Elevated levels of radionuclides are attributed to the ingestion of food, sediment, and water by the waterfowl from the contaminated ponds where they were collected. In general, higher concentrations were found in diving ducks than in surface ducks. See chapter 8 for a radiation dose estimate for humans ingesting these contaminated waterfowl.

Seven doves were collected during 1997; three from TRA and four from INTEC. Of the three from TRA, all were analyzed for gamma emitters, and two were analyzed for ${ }^{90} \mathrm{Sr},{ }^{238} \mathrm{Pu}$, ${ }^{239 / 240} \mathrm{Pu}$, and ${ }^{241} \mathrm{Am}$. Of the four doves from INTEC, all were analyzed for gamma emitters, and one was analyzed for ${ }^{90} \mathrm{Sr},{ }^{238} \mathrm{Pu},{ }^{239 / 240} \mathrm{Pu}$, and ${ }^{241} \mathrm{Am}$. The concentrations measured in these doves are summarized in Table 4-9. See chapter 8 for a radiation dose estimate for humans ingesting these doves.

\subsection{ENVIRONMENTAL DOSIMETERS}

The measured cumulative radiation exposure for offsite locations for the time period from November 1996 to November 1997 is shown in Table 4-10 for the duplicate set of dosimeters maintained by the Foundation and LMITCO. For purposes of comparison, annual exposures from 1993-96 are also included for each location.

The mean annual exposures for distant locations in 1997 were $130 \pm 8 \mathrm{mR}$ as measured by Foundation dosimeters and $123 \pm 9 \mathrm{mR}$, as measured by LMITCO's dosimeters. For 


\section{TABLE 4-10. ENVIRONMENTAL RADIATION EXPOSURES (1993-1997)}

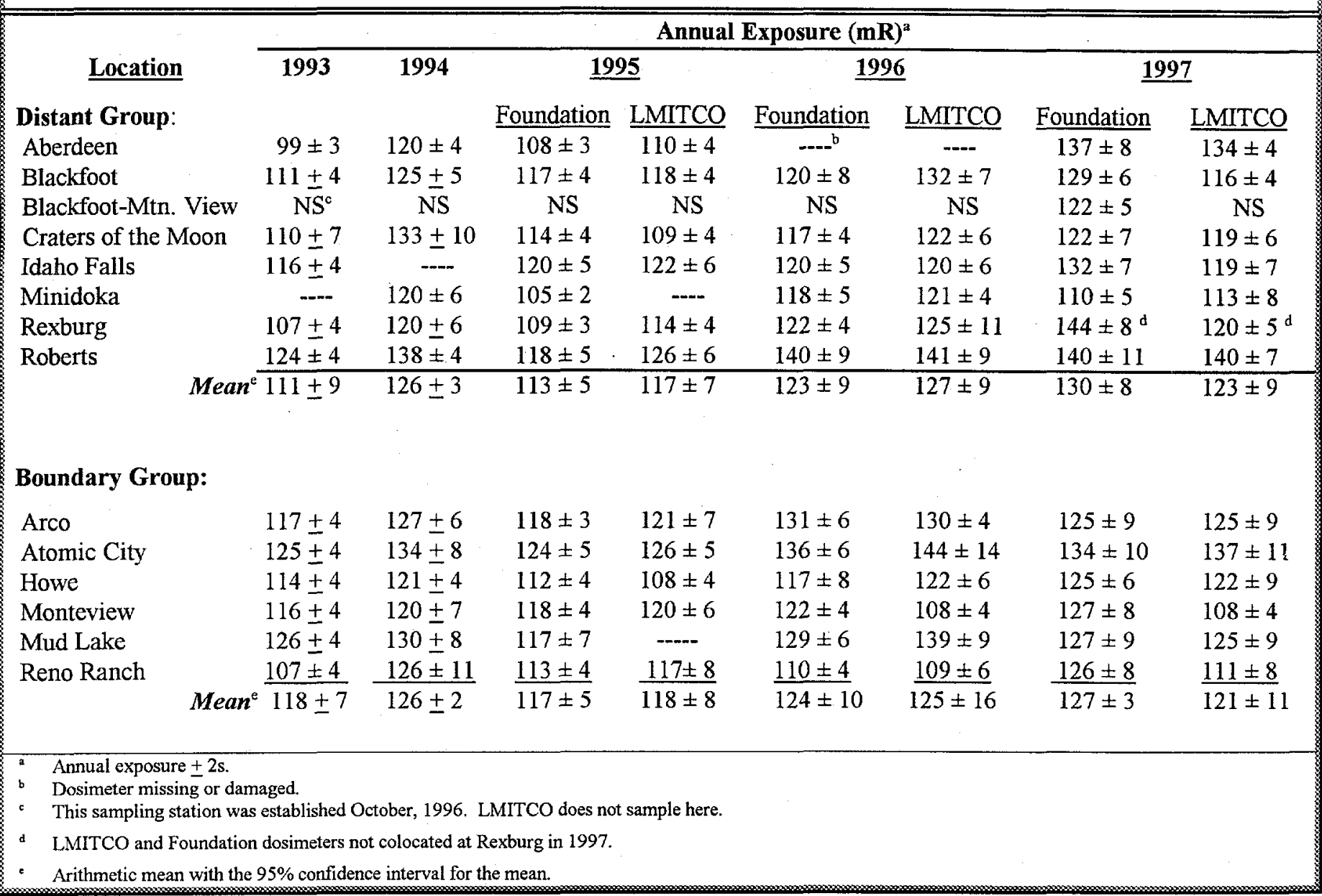

boundary locations, the mean annual exposures were $124 \pm 10 \mathrm{mR}$ as measured by Foundation dosimeters and $125 \pm 15 \mathrm{mR}$ as measured by LMITCO's dosimeters. Using the average of both sets of data, the average exposure of the distant group was equivalent to $128 \mathrm{mrem}$, when a dose equivalent conversion factor of 1.03 was used to convert from $\mathrm{mR}$ to mrem in tissue. The average exposure for the boundary group was also 128 mrem [Reference 4-2].

Table 4-11 summarizes the calculated effective dose equivalent an individual receives on the Snake River Plain from various background radiation sources. The terrestrial portion of this value is based on concentrations of naturally occurring radionuclides found in soil samples collected in 1976. Data indicated the average concentrations of ${ }^{238} \mathrm{U},{ }^{232} \mathrm{Th}$, and ${ }^{40} \mathrm{~K}$ were $1.5,1.3$, and $19 \mathrm{pCi} / \mathrm{g}$, respectively. These are very long-lived radionuclides and soil concentrations remain, on the average, constant over many years. Estimates of the average external dose equivalent received by a member of the public from ${ }^{238} \mathrm{U}$ plus decay products, ${ }^{232} \mathrm{Th}$ plus decay products, and ${ }^{40} \mathrm{~K}$ based on the above average area soil concentrations were calculated to be 21,28 , and $27 \mathrm{mrem} / \mathrm{yr}$, respectively, for a total of $76 \mathrm{mrem} / \mathrm{yr}$. Because snow cover can reduce the effective dose equivalent Idaho residents receive from the soil, a correction factor must be made each year to the above estimate of 


\begin{tabular}{|c|c|c|}
\hline \multirow{2}{*}{$\begin{array}{l}\text { Source of Radiation Dose } \\
\text { Equivalent }\end{array}$} & \multicolumn{2}{|c|}{ Total Average Annual Effective Dose Equivalent } \\
\hline & Estimated & Measured \\
\hline \multicolumn{3}{|l|}{ External } \\
\hline Terrestrial & 74 & N/A \\
\hline Cosmic & $\underline{48}$ & $\underline{N} / \mathrm{A}$ \\
\hline Subtotal & 122 & 128 \\
\hline \multicolumn{3}{|l|}{ Internal } \\
\hline Cosmogenic & 1 & \\
\hline Inhaled Radionuclides & 200 & \\
\hline${ }^{40} \mathrm{~K}$ and others & $\underline{39}$ & \\
\hline Subtotal & 240 & \\
\hline Total & 362 & \\
\hline
\end{tabular}

$76 \mathrm{mrem} / \mathrm{yr}$. For 1997, this resulted in 74 $\mathrm{mrem} / \mathrm{yr}$ (3\% dose reduction) due to snow cover, which reached a maximum depth of $18 \mathrm{~cm}$ (7 in).

The cosmic component varies primarily with altitude increasing from about 26 mrem at sea level to about 48 mrem at the elevation of the NEEL at approximately $1,500 \mathrm{~m}(4,900 \mathrm{ft}$.) [Reference 4-3]. This may vary slightly due to solar cycle fluctuations and other factors.

The estimated sum of the terrestrial and cosmic components for 1997 was $122 \mathrm{mrem}$. This is comparable to the value of $128 \mathrm{mR}$ measured at distant locations thermoluminescent dosimeters (TLDs), after conversion from $\mathrm{mR}$ to mrem in tissue.

The component of background dose that varies the most is that of inhaled radionuclides. According to the National Council on Radiation Protection, the major radionuclides contributing to this component are short-lived decay products of radon, and the amount of radon in buildings and ground water depends, in part, upon the natural radionuclide content of the soil and rock of the area. There is also variation between buildings of a given geographic area depending upon the materials each contains, the amount of ventilation and air movement, and other factors. The U.S. average of $200 \mathrm{mrem}$ has been used in Table 4-11 for this component of the total background dose because no specific estimate for southeastern Idaho has been made, and few specific measurements have been made of radon in homes in this area. Therefore, the effective dose equivalent from natural background radiation for residents in the INEEL vicinity may actually be higher or lower than the total estimated background dose of about $360 \mathrm{mrem}$ shown in Table 4-11 and will vary from one location to another. 
Onsite TLDs representing the same exposure period as the offsite dosimeters are shown in Figures 4-3 through 4-12. The results are expressed in $\mathrm{mR} \pm 2 \mathrm{~s}$. Onsite dosimeters were placed on facility perimeters, concentrated in areas likely to show the highest gamma radiation readings. At TRA, for example, dosimeters \#2, \#3, \#4, and \#5 are adjacent to the former radioactive disposal pond which has been drained and covered by clean soil. Other dosimeters are located near radioactive material storage areas. At some facilities, particularly ARA and INTEC, slightly elevated exposures result from soil contamination around the perimeter of these facilities. 


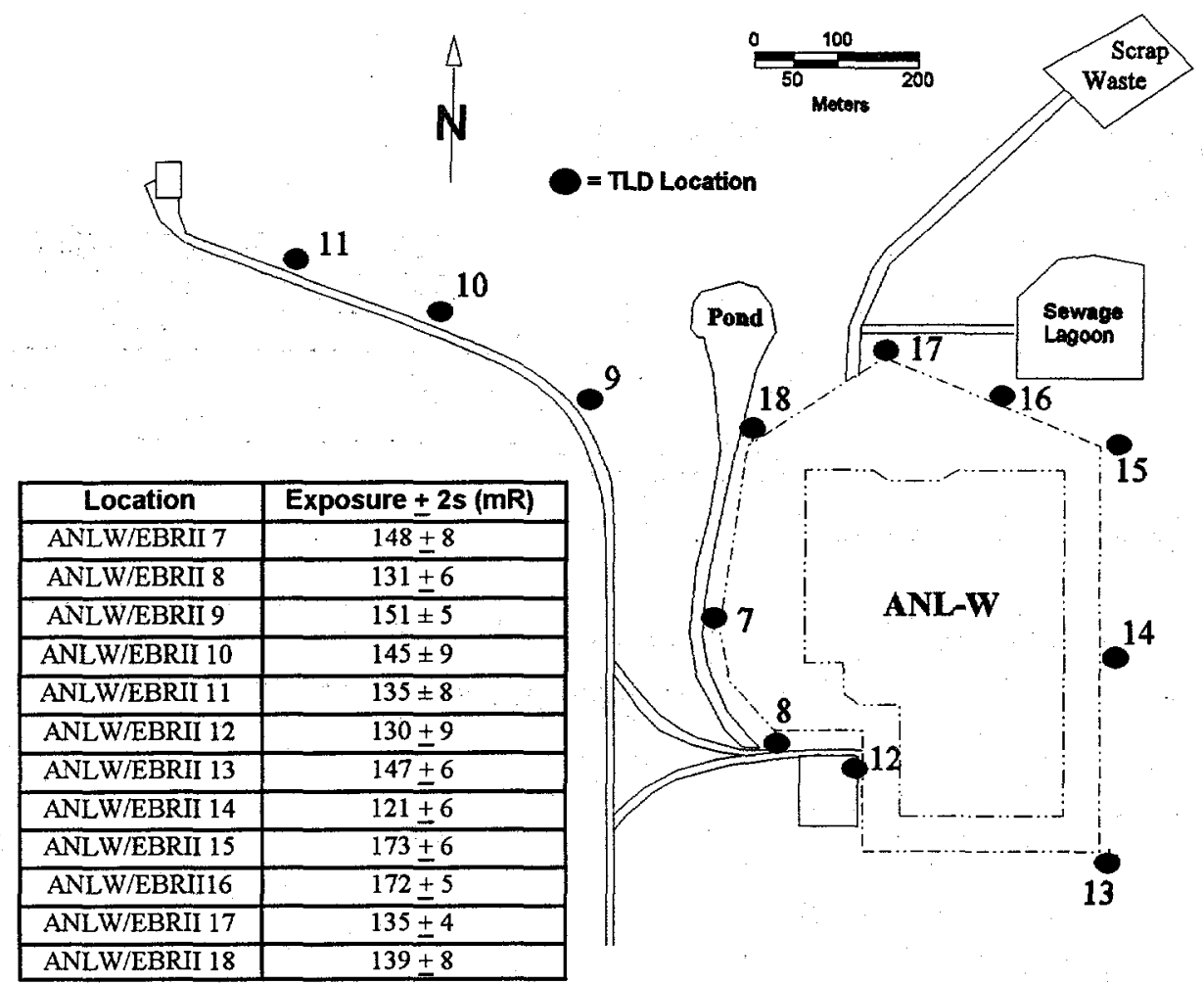

Figure 4-3. Environmental Dosimeter Measurements at ANL-W (1997)

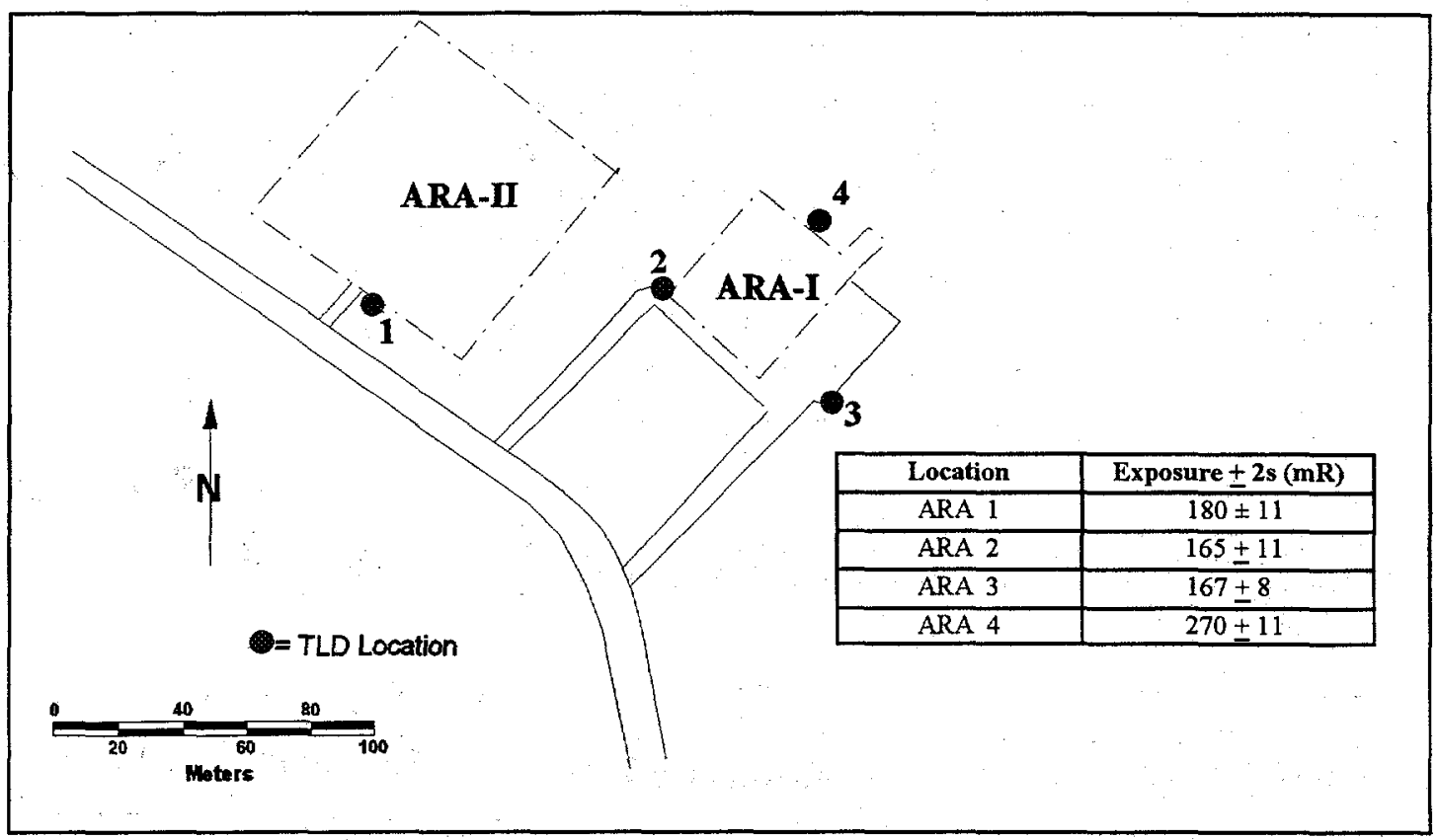

Figure 4-4. Environmental Dosimeter Measurements at ARA (1997) 


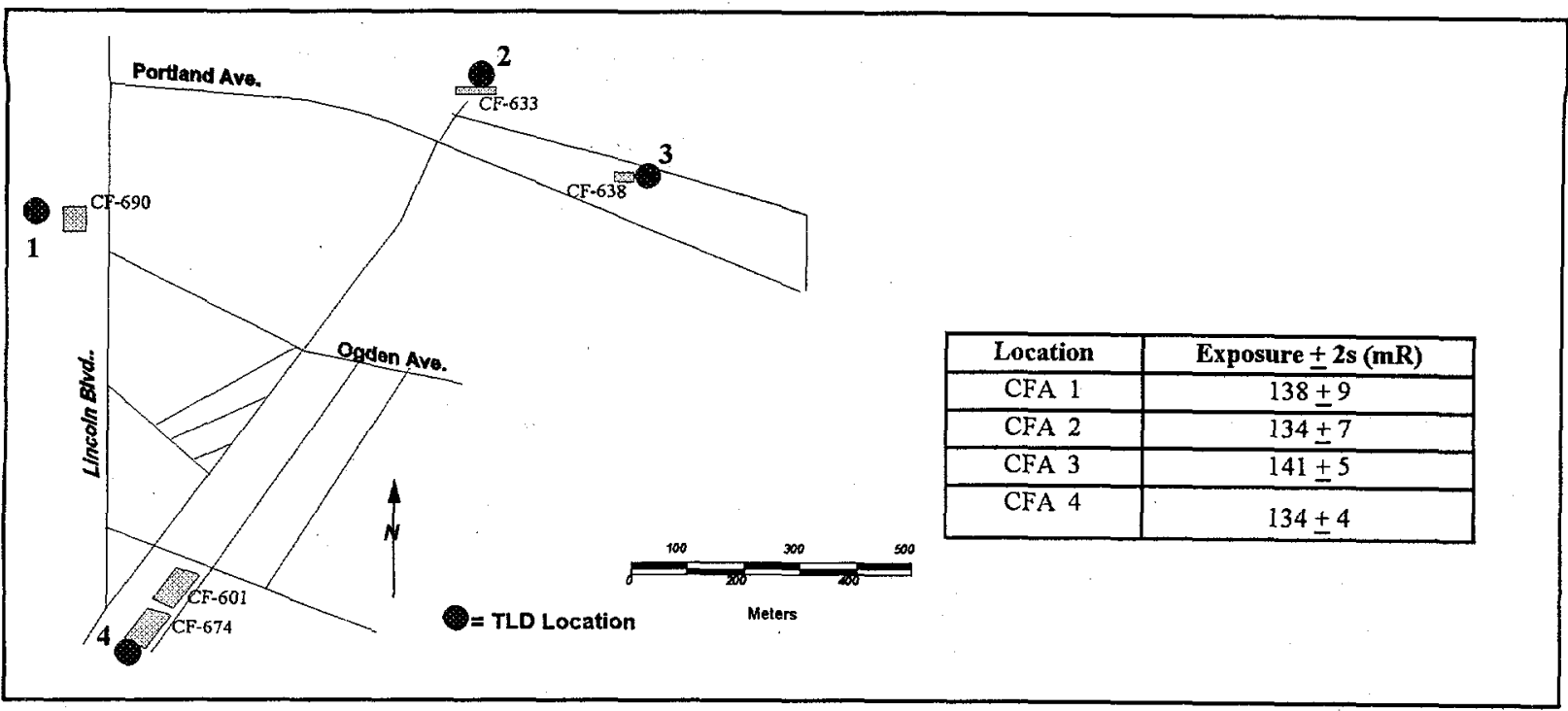

Figure 4-5. Environmental Dosimeter Measurements at CFA (1997)

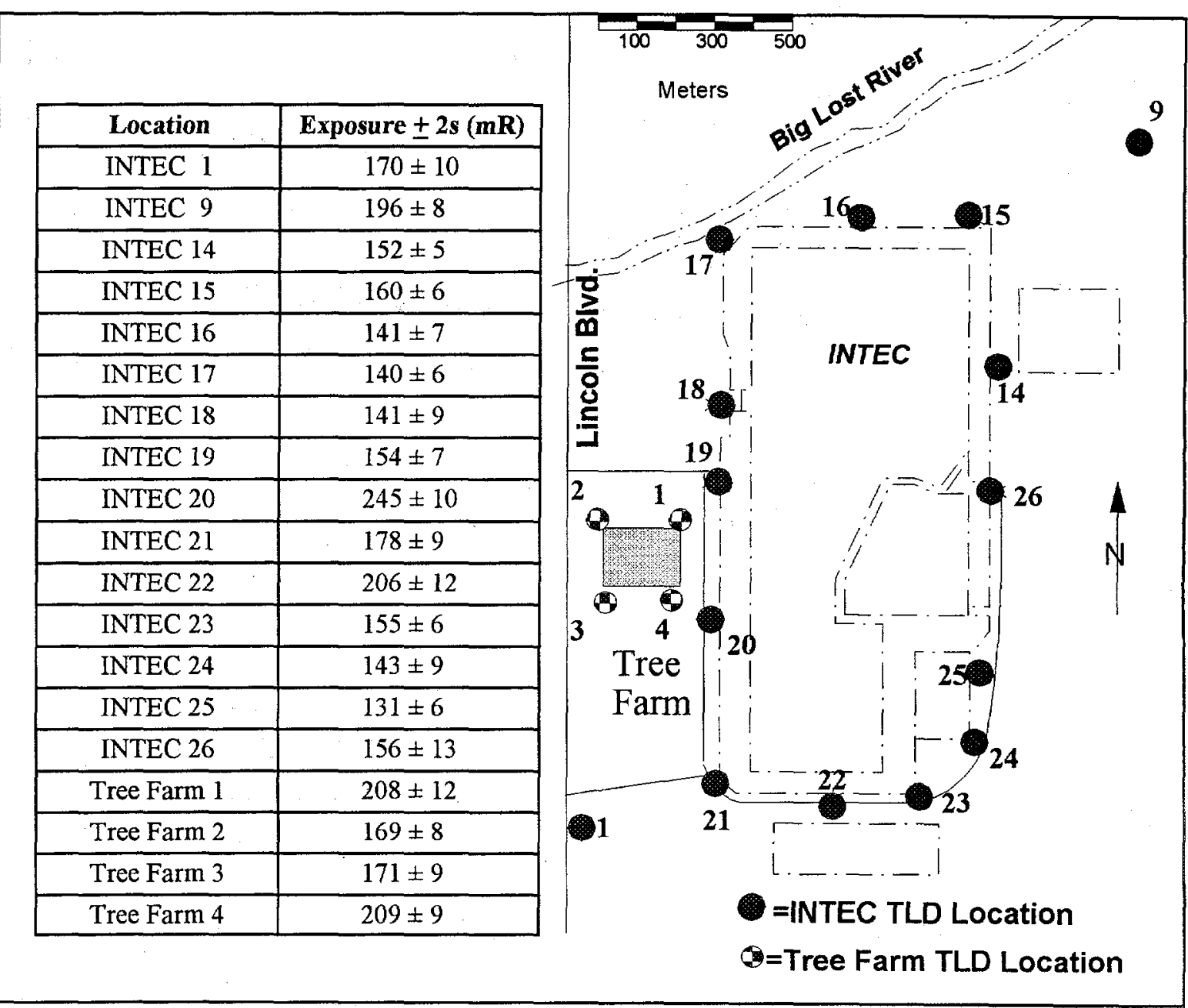

Figure 4-6. Environmental Dosimeter Measurements at INTEC (1997) 


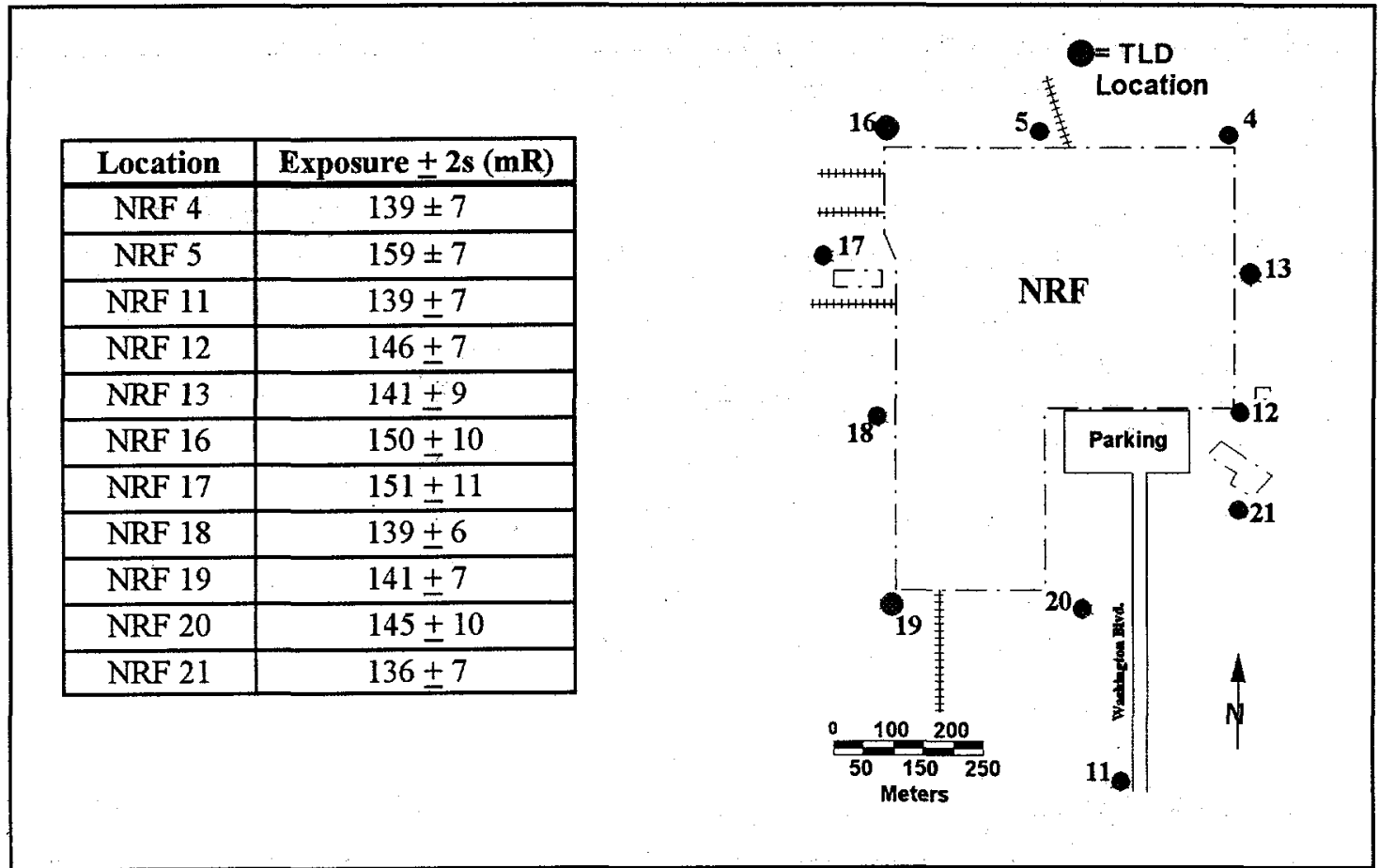

Figure 4-7. Environmental Dosimeter Measurements at NRF (1997)

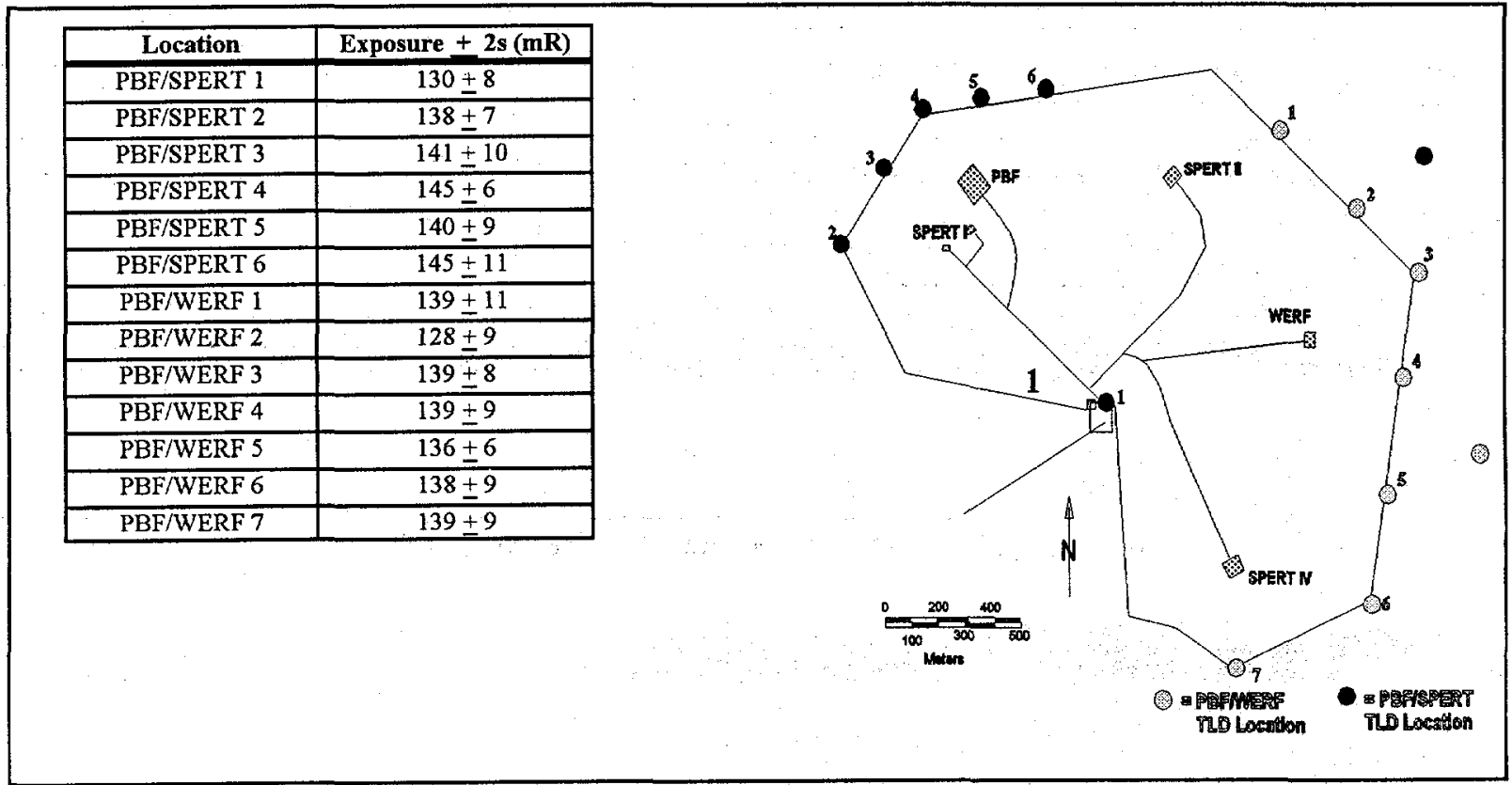

Figure 4-8. Environmental Dosimeter Measurements at PBF (1997) 


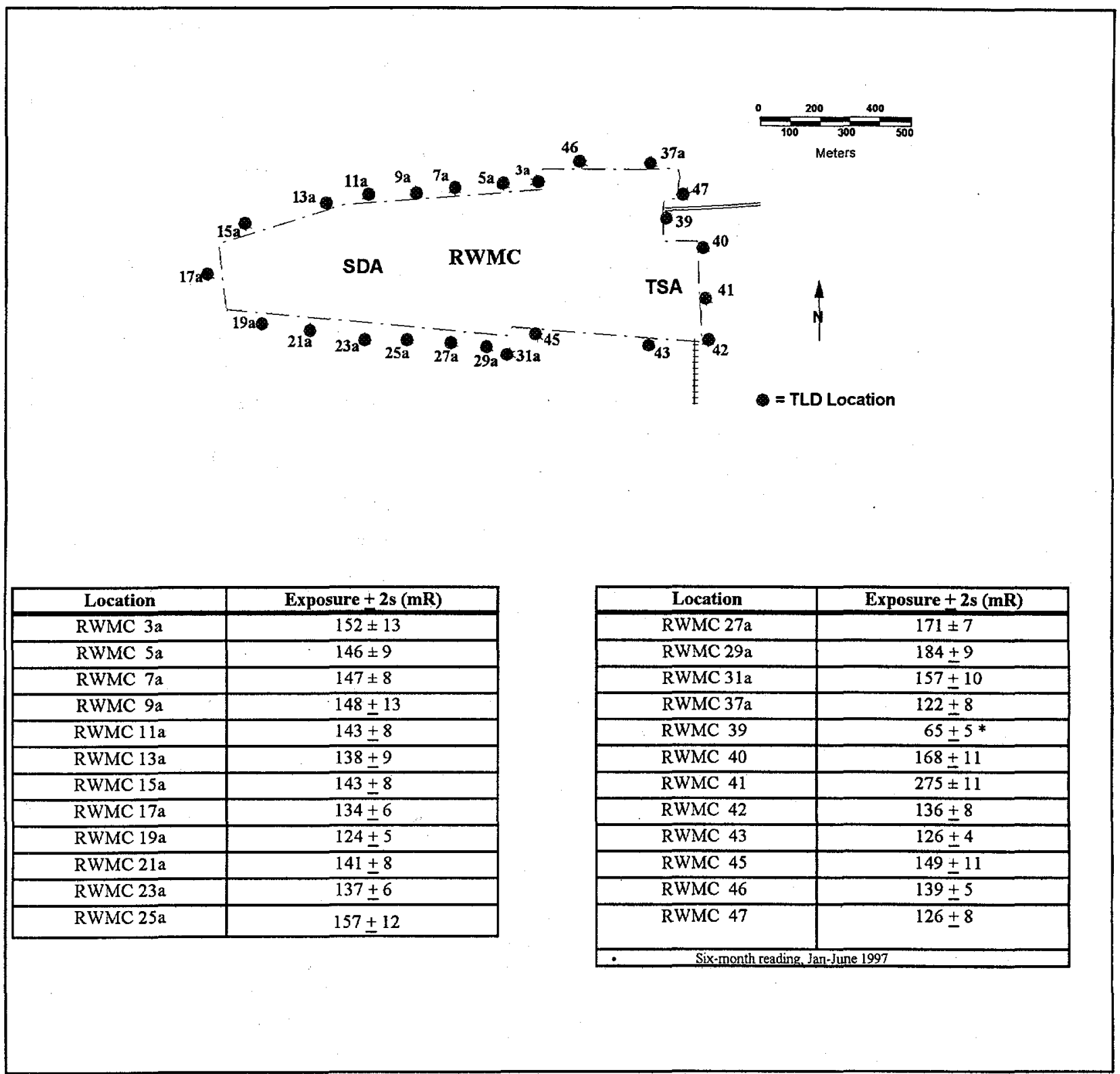

Figure 4-9. Environmental Dosimeter Measurements at RWMC (1997) 


\begin{tabular}{|c|c|}
\hline Location & Exposure \pm 2s (mR) \\
\hline TAN/TSF 1 & $129 \pm 7$ \\
\hline TAN/TSF 2 & $143 \pm 8$ \\
\hline TAN/TSF 3 & $123 \pm 9$ \\
\hline TAN/TSF 4 & $130 \pm 9$ \\
\hline TAN/LOFT 1 & $132 \pm 7$ \\
\hline TAN/LOFT 2 & $149 \pm 8$ \\
\hline TAN/LOFT 3 & $118 \pm 6$ \\
\hline TAN/LOFT 4 & $129 \pm 5$ \\
\hline TAN/LOFT 5 & $135 \pm 9$ \\
\hline TAN/LOFT 6 & $147 \pm 6$ \\
\hline TAN/LOFT 7 & $141 \pm 7$ \\
\hline TAN/WRRTF 1 & $133 \pm 6$ \\
\hline TAN/WRRTF 2 & $123 \pm 7$ \\
\hline TAN/WRRTF 3 & $123 \pm 6$ \\
\hline TAN/WRRTF 4 & $124 \pm 9$ \\
\hline
\end{tabular}

$$
\begin{gathered}
=\begin{array}{c}
=\text { TSF TLD } \\
\text { Location }
\end{array} \\
\theta=\text { LOFT TLD } \\
\text { LOCation } \\
=\text { WTRRTF TLD } \\
\text { LOCStlon }
\end{gathered}
$$

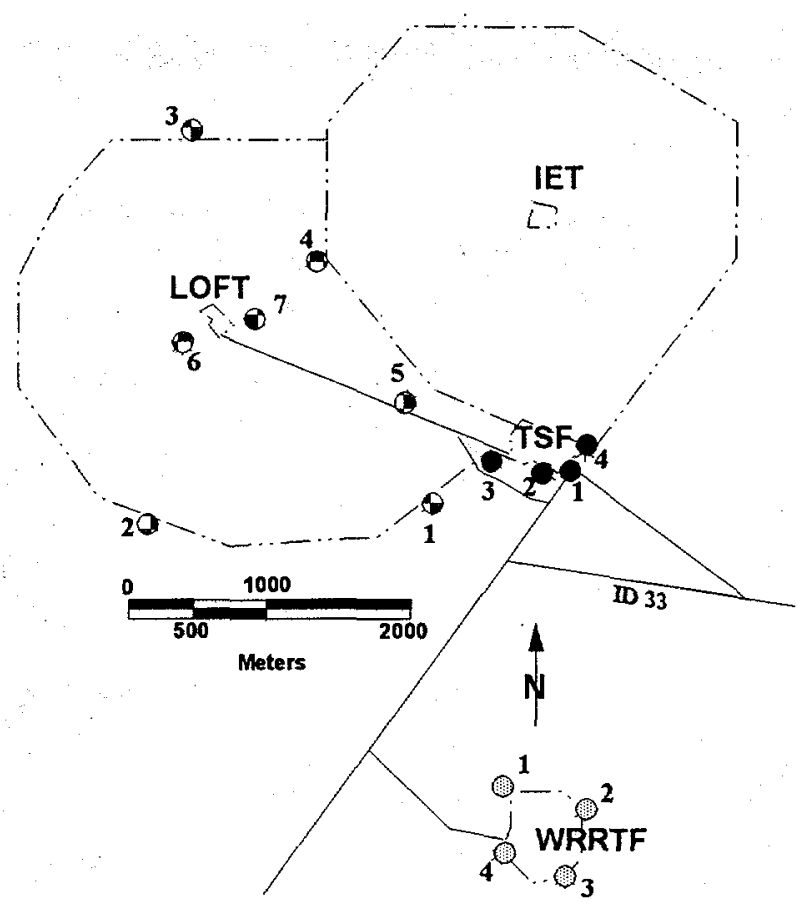

Figure 4-10. Environmental dosimeter measurements at TAN (1997)

\begin{tabular}{|c|c|}
\hline Location & Exposure \pm 2s (mR) \\
\hline TRA 1 & $155 \pm 8$ \\
\hline TRA 2 & $257 \pm 9$ \\
\hline TRA 3 & $328 \pm 16$ \\
\hline TRA 4 & $246 \pm 12$ \\
\hline TRA 5 & $186 \pm 9$ \\
\hline TRA 6 & $149 \pm 8$ \\
\hline TRA 7 & $169 \pm 11$ \\
\hline TRA 8 & $185 \pm 8$ \\
\hline TRA 9 & $152 \pm 8$ \\
\hline TRA 10 & $156 \pm 9$ \\
\hline TRA 11 & $145 \pm 8$ \\
\hline TRA 12 & $149 \pm 6$ \\
\hline TRA 13 & $156 \pm 13$ \\
\hline
\end{tabular}
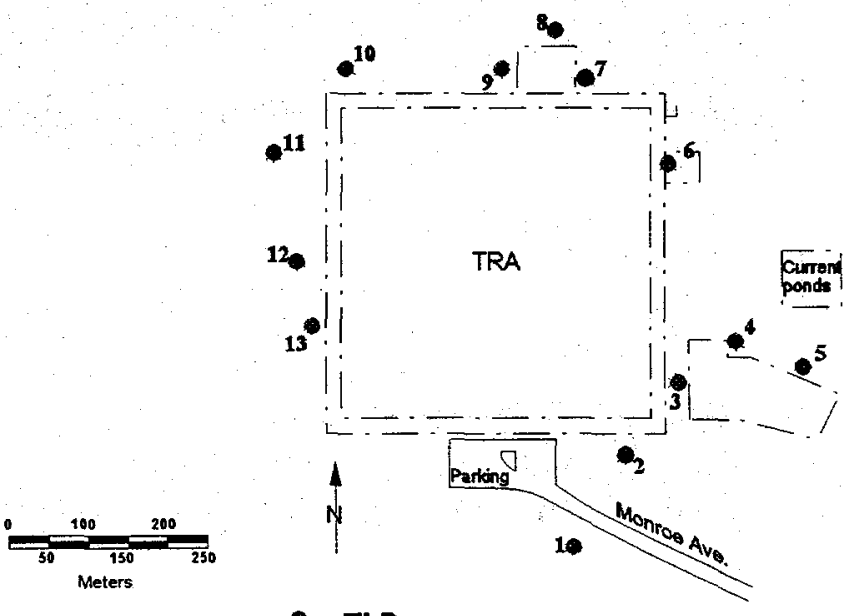

$\bullet=$ TLD

Location

Figure 4-11. Environmental Dosimeter Measurements at TRA (1997) 


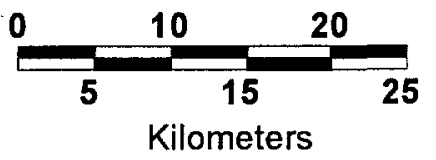

- Lincoln Blvd. TLD Location

\section{$=$ US Highway 20/26} TLD Location

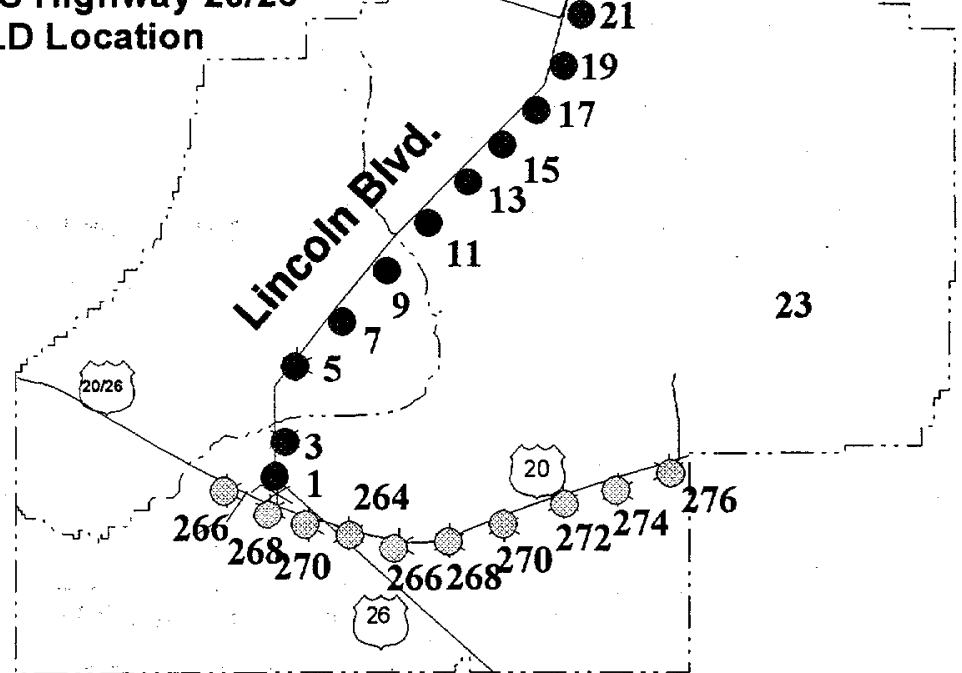

\begin{tabular}{|c|c|}
\hline Location & Exposure \pm 2s (mR) \\
\hline LINCOLN BLVD. 1 & $144 \pm 13$ \\
\hline LINCOLN BLVD. 3 & $154 \pm 7$ \\
\hline LINCOLN BLVD. 5 & $150 \pm 6$ \\
\hline LINCOLN BLVD. 7 & $138 \pm 9$ \\
\hline LINCOLN BLVD. 9 & $146 \pm 9$ \\
\hline LINCOLN BLVD. 11 & $143 \pm 7$ \\
\hline LINCOLN BLVD. 13 & $136 \pm 10$ \\
\hline LINCOLN BLVD. 15 & $146 \pm 5$ \\
\hline LINCOLN BLVD. 17 & $149 \pm 6$ \\
\hline LINCOLN BLVD. 19 & $151 \pm 12$ \\
\hline LINCOLN BLVD. 21 & $140 \pm 12$ \\
\hline LINCOLN BLVD. 23 & $137 \pm 6$ \\
\hline LINCOLN BLVD. 25 & $137 \pm 9$ \\
\hline
\end{tabular}

\begin{tabular}{|c|c|}
\hline Location & Exposure \pm 2s (mR) \\
\hline HIGHWAY 26 mile 266 & $134 \pm 6$ \\
\hline HIGHWAY 26 mile 268 & $130 \pm 7$ \\
\hline HIGHWAY 26 mile 270 & $138 \pm 5$ \\
\hline HIGHWAY 20 mile 264 & $134 \pm 6$ \\
\hline HIGHWAY 20 mile 266 & $126 \pm 9$ \\
\hline HIGHWAY 20 mile 268 & $138 \pm 12$ \\
\hline HIGHWAY 20 mile 270 & $144 \pm 11$ \\
\hline HIGHWAY 20 mile 272 & $132 \pm 5$ \\
\hline HIGHWAY 20 mile 274 & $130 \pm 8$ \\
\hline HIGHWAY 20 mile 276 & $122 \pm 8$ \\
\hline
\end{tabular}

Figure 4-12. Environmental Dosimeter Measurements along Lincoln Blvd. and US Highways 20 and 26 (1997) 


\section{Summary of Chapter 5 \\ Nonradiological Environmental Monitoring Results}

The Environmental Science and Research Foundation monitored airborne particulates both on the INEEL and at offsite locations, whileLockheed Martin Idaho Technologies Company (LMITCO) monitored air and storm water for nonradiological parameters on the INEEL. Concentrations of airborne particulates were measured in three different size fractions: the total amount of particulates collected on low-volume air filters, the amount less than 10 micrometers in diameter $\left(\mathrm{PM}_{10}\right)$, and the amount of very fine material less than 2.5 micrometers in diameter $\left(\mathrm{PM}_{2.5}\right)$. As part of a nationwide National Park Service program, additional monitoring was performed for several different parameters which can contribute to visibility impairment. Nitrogen dioxide and sulfur dioxide measured at onsite locations were substantially below air quality standards for these parameters set by the U.S. Environmental Protection Agency (EPA).

Storm water runoff from snowmelt and precipitation events was collected and analyzed for a variety of nonradiological substances and parameters, as required by the 1995 NPDES General Permit. Comparisons were made between measurements of these quantities in storm water and EPA benchmarks for storm water runoff in order to assess the water quality of these discharges. Levels of one or more parameters in storm water were above the corresponding benchmarks at three monitoring points. However, no storm water discharge from INEEL facilities reached any permanent surface streams. 



\section{NONRADIOLOGICAL ENVIRONMENTAL MONITORING RESULTS}

\subsection{TOTAL SUSPENDED PARTICULATES}

Concentrations of total suspended particulates were measured in 1997 by both the Environmental Science and Research Foundation and LMITCO using filters from low-volume air samplers. The filters are $99 \%$ efficient for collection of particles greater than $0.3 \mu \mathrm{m}$ in diameter. Unlike the fine particulate samplers discussed in Section 5.2, these samplers do not selectively filter out particles of a certain size range, and so measure the total amount of particulate matter.

The annual mean of total suspended particulate concentrations ranged from $5 \mu \mathrm{g} / \mathrm{m}^{3}$ at CFA on the INEEL to $56 \mu \mathrm{g} / \mathrm{m}^{3}$ at Mud Lake (Table 5-1).

Particulate concentrations were generally higher at distant and boundary locations than at the INEEL stations. The largest source of particulates in eastern Idaho is considered to be suspended dust from agricultural activities. Second and third quarter concentrations were higher than during other quarters at most of the locations, consistent with dryer conditions found in summer and autumn months. Overall, however, annual onsite particulate concentrations were lower than in other recent years (Table 5-2).

\subsection{FINE PARTICULATES $\left(\mathrm{PM}_{10}\right)$}

The EPA began using a new standard for concentrations of airborne particulate matter in 1987. The new standard refers only to "particles with an aerodynamic diameter less than or equal to a nominal 10 micrometers" [Reference 5-1]. Particles of this size, which can reach the lungs, are considered to be responsible for most of the adverse health effects associated with airborne particulate pollution. The air quality standards for fine particulates, generally referred to as $\mathrm{PM}_{10}$, are an annual average of $50 \mu \mathrm{g} / \mathrm{m}^{3}$, with a maximum 24-hour concentration of $150 \mu \mathrm{g} / \mathrm{m}^{3}$.
Forty-nine samples were collected at Rexburg by the Foundation from January through December 1997. Concentration of fine particulates ranged from $-3 \mu \mathrm{g} / \mathrm{m}^{3}$ to $53 \mu \mathrm{g} / \mathrm{m}^{3}$, with a mean of $14 \pm 4 \mu \mathrm{g} / \mathrm{m}^{3}$. At Mountain View Middle School in Blackfoot, 41 samples were collected from March through December. Concentrations ranged from $-3 \mu \mathrm{g} / \mathrm{m}^{3}$ to $61 \mu \mathrm{g} / \mathrm{m}^{3}$. The mean concentration at this location was $15 \pm 4 \mu \mathrm{g} / \mathrm{m}^{3}$. At Atomic City, where sampling for fine particulates began in March 1997, 29 samples were collected from March through December. Concentrations ranged from 0 to $121 \mu \mathrm{g} / \mathrm{m}^{3}$, with a mean of $15 \pm 10 \mu \mathrm{g} / \mathrm{m}^{3}$.

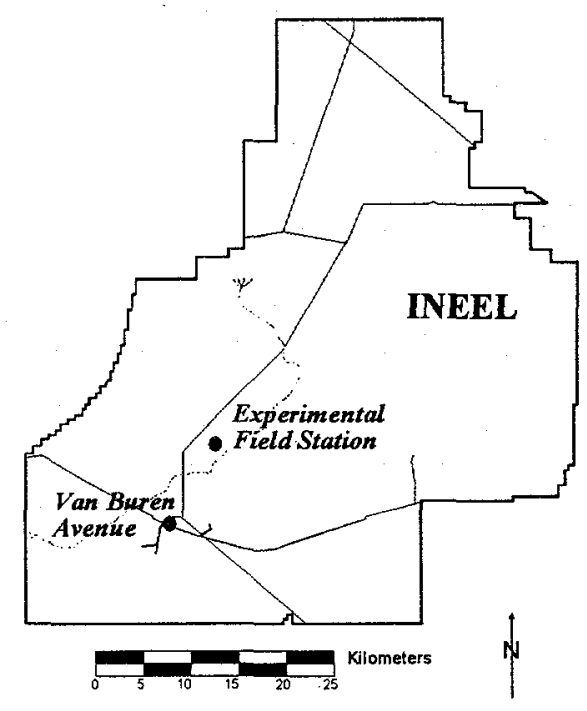

Figure 5-1. Nitrogen Oxides and Sulfur Dioxide Monitoring Locations

\subsection{NITROGEN DIOXIDE}

Nitrogen dioxide was monitored by LMITCO at Van Buren Avenue and the Experimental Field Station (EFS) (Figure 5-1) throughout 1997. At Van Buren, quarterly mean concentrations ranged from $2.5 \mu \mathrm{g} / \mathrm{m}^{3}$ to $5.6 \mu \mathrm{g} / \mathrm{m}^{3}$, with an annual mean of $4.4 \mu \mathrm{g} / \mathrm{m}^{3}(2.3 \mathrm{ppb})$. This annual concentration is $4 \%$ of the EPA air 


\begin{tabular}{|c|c|c|c|}
\hline \multicolumn{4}{|c|}{ 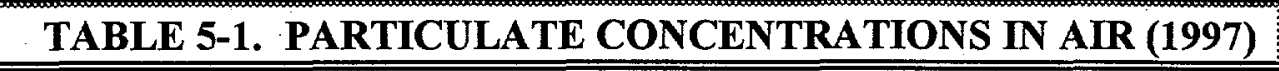 } \\
\hline \multicolumn{4}{|c|}{ Environmental Science and Research Foundation Data } \\
\hline \multirow[b]{2}{*}{ Group } & \multirow[b]{2}{*}{ Location } & \multicolumn{2}{|c|}{ Concentration $\left(\mu \mathrm{g} / \mathrm{m}^{3}\right)$} \\
\hline & & Range $^{\mathbf{a}}$ & Mean $^{b}$ \\
\hline \multirow[t]{6}{*}{ Distant } & $\overline{\text { Blackfoot }}$ & $0-20$ & $\overline{10 \pm 9}$ \\
\hline & Blackfoot-Mtn. View M.S. & $1-22$ & $14 \pm 8$ \\
\hline & Craters of the Moon & $7-10$ & $8 \pm 1$ \\
\hline & Idaho Falls & $2-27$ & $17 \pm 10$ \\
\hline & Rexburg-Madison M.S. & $7-27$ & $\underline{18 \pm 7}$ \\
\hline & & Grand Mean ${ }^{b}$ & $\overline{13 \pm 4}$ \\
\hline \multirow[t]{8}{*}{ Boundary } & Arco & $4-50$ & $27 \pm 16$ \\
\hline & Atomic City & $0-19$ & $11 \pm 8$ \\
\hline & FAA Tower & $0-15$ & $3 \pm 9$ \\
\hline & Howe & $1-25$ & $13 \pm 9$ \\
\hline & Monteview & $5-25$ & $15 \pm 8$ \\
\hline & Mud Lake & $5-186$ & $56 \pm 74$ \\
\hline & Reno Ranch & $0-15$ & $5 \pm 9$ \\
\hline & & Grand Mean ${ }^{b}$ & $19 \pm 13$ \\
\hline \multirow[t]{4}{*}{ INEEL } & EFS & $0-12$ & $5 \pm 8$ \\
\hline & Main Gate & $0-10$ & $5 \pm 5$ \\
\hline & Van Buren & $4-13$ & $\underline{9 \pm 4}$ \\
\hline & & Grand Mean ${ }^{b}$ & $\overline{6 \pm 3}$ \\
\hline \multicolumn{4}{|c|}{ LMTTCO Data } \\
\hline \multirow[b]{2}{*}{ Group } & \multirow[b]{2}{*}{ Location } & \multicolumn{2}{|c|}{ Concentration $\left(\mu \mathrm{g} / \mathrm{m}^{3}\right)$} \\
\hline & & Range $^{a}$ & Mean \\
\hline \multirow[t]{5}{*}{$\overline{\text { Distant }}$} & Blackfoot & $4-19$ & $12 \pm 7$ \\
\hline & Craters of the Moon & $6-10$ & $8 \pm 2$ \\
\hline & Idaho Falls & $10-26$ & $18 \pm 7$ \\
\hline & Rexburg & $17-20$ & $\underline{18 \pm 2}$ \\
\hline & & Grand Mean & $14 \pm 3$ \\
\hline \multirow[t]{13}{*}{ INEEL } & ANL-W & $9-17$ & $13 \pm 4$ \\
\hline & ARA & $4-9$ & $7 \pm 2$ \\
\hline & CFA & $4-6$ & $5 \pm 1$ \\
\hline & EBRl & $4-13$ & $8 \pm 4$ \\
\hline & EFS & $4-13$ & $9 \pm 4$ \\
\hline & ICPP & $6-23$ & $10 \pm 8$ \\
\hline & NRF & $5-8$ & $7 \pm 1$ \\
\hline & PBF & $8-11$ & $9 \pm 1$ \\
\hline & RWMC & $6-15$ & $10 \pm 4$ \\
\hline & TAN & $5-11$ & $8 \pm 2$ \\
\hline & TRA & $4-15$ & $9 \pm 5$ \\
\hline & VANB & $6-11$ & $\underline{9 \pm 2}$ \\
\hline & & Grand Mean ${ }^{b}$ & $9 \pm 1$ \\
\hline
\end{tabular}


quality standard of $100 \mu \mathrm{g} / \mathrm{m}^{3}$ for nitrogen dioxide. The maximum 24-hour concentration measured was $6.2 \mu \mathrm{g} / \mathrm{m}^{3}$ (3.3 ppb) on July 20. Data were obtained at the Van Buren station for $89 \%$ of the year.

Quarterly means at EFS ranged from $4.4 \mu \mathrm{g} / \mathrm{m}^{3}$ during the second quarter to $14.3 \mu \mathrm{g} / \mathrm{m}^{3}$ during the third quarter. For the year, the mean concentration was $8.5 \mu \mathrm{g} / \mathrm{m}^{3}(4.5 \mathrm{ppb})$, or $9 \%$ of the EPA standard. The maximum 24hour average concentration occurred on August 3, when a value of $19.2 \mu \mathrm{g} / \mathrm{m}^{3}$ (10.2 ppb) was recorded. Data were obtained at the EFS location for $92 \%$ of the year.

When operating, the New Waste Calcining Facility at the Idaho Nuclear Technology and Engineering Center (INTEC) is the largest single source of nitrogen dioxide at the INEEL. A graph of nitrogen dioxide at the two sampling locations may indicate some effect from this facility on ambient concentrations of nitrogen dioxide, particularly at EFS located approximately $5 \mathrm{~km}$ ( 3 miles) in the prevailing wind direction from INTEC (Figure 5-2). All quarterly concentrations have remained below $50 \%$ of the annual standard throughout the time period of monitoring. The New Waste Calcining Facility did not operate from October 1993 until mid-1997. Further information on airborne nitrogen dioxide effluents released during 1997 is provided in Chapter 7.

\subsection{SULFUR DIOXIDE}

Sulfur dioxide was measured at the Van Buren Avenue monitoring location, and the analyzer operated satisfactorily for $93 \%$ of the year. For sulfur dioxide, there are three separate EPA standards [Reference 5-2]. The mean sulfur dioxide concentration for 1997 was $5.2 \mu \mathrm{g} / \mathrm{m}^{3}$
$(2.0 \mathrm{ppb})$, or $6.5 \%$ of the annual primary air quality standard of $80 \mu \mathrm{g} / \mathrm{m}^{3}$. There is a second primary air quality standard for the maximum 24-hour concentration, not to be exceeded more than once per year. In 1997 the maximum recorded 24-hour $\mathrm{SO}_{2}$ concentration at Van Buren was $23.2 \mu \mathrm{g} / \mathrm{m}^{3}$ (8.7 ppb) on April 7, which did not approach the standard of $365 \mu \mathrm{g} / \mathrm{m}^{3}$.

In addition to the primary standards, there is a secondary ambient air quality standard. The secondary standard refers to the maximum 3-hour concentration, which can not exceed 1300 $\mu \mathrm{g} / \mathrm{m}^{3}$ more than once per year. The highest 3-hour concentration of $24.8 \mu \mathrm{g} / \mathrm{m}^{3}$ (9.3 ppb) was also measured on April 7; this is approximately $1.9 \%$ of the secondary standard.

\subsection{IMPROVE SAMPLERS}

Interagency Monitoring of Protected Visual Environment (IMPROVE) samplers have operated continuously at Craters of the Moon 


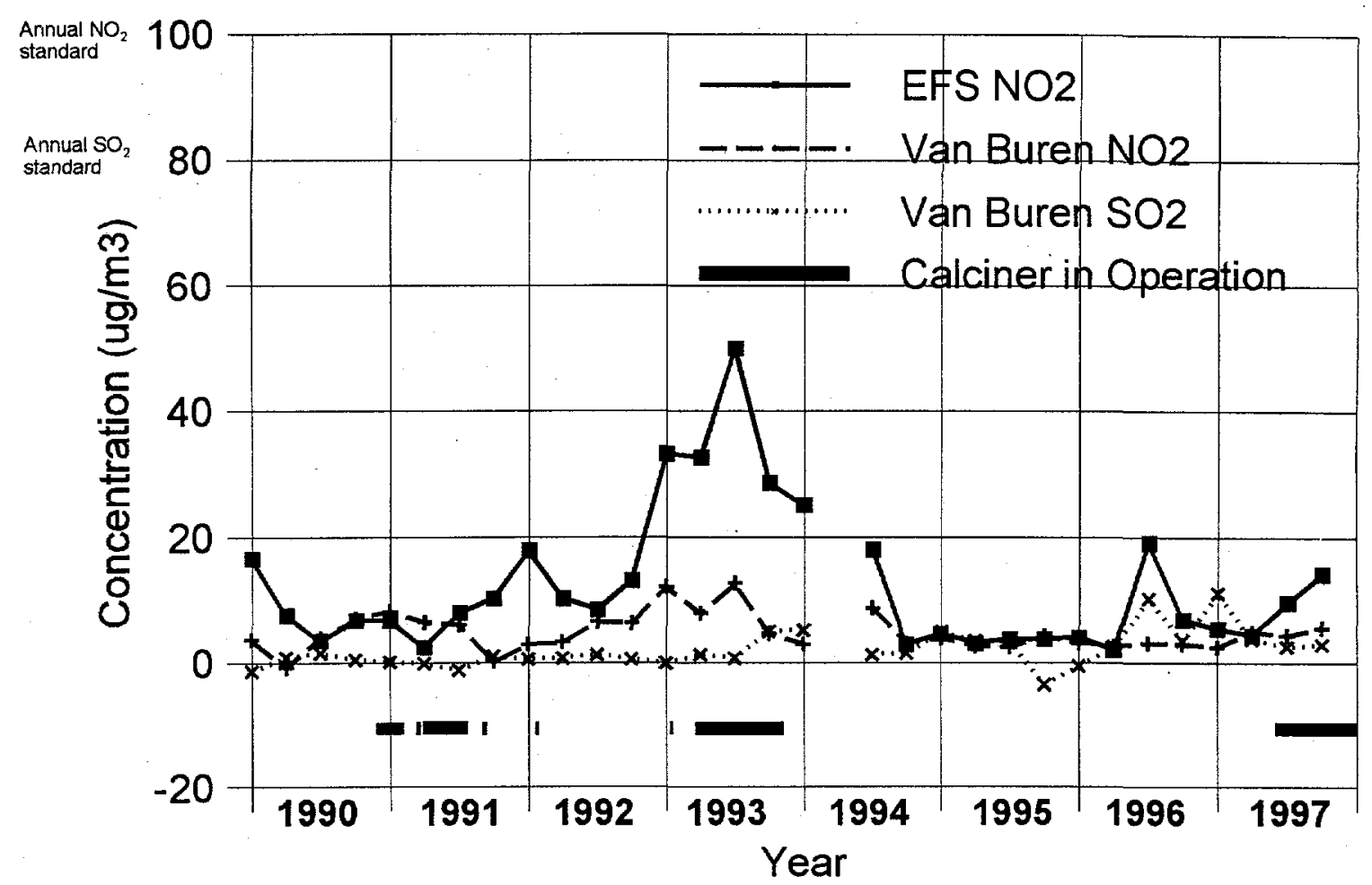

Figure 5-2. Nitrogen Dioxide and Sulfur Dioxide Concentrations at the INEEL (1990-1997

National Monument and Central Facilities Area (CFA) since the spring of 1992. The most recent data available are through May 1997. A summary of the data for hydrogen and elements sodium through lead on the periodic table are shown in Table 5-3.

Several elements measured, including aluminum, silicon, calcium, titanium, and iron, are derived from soils, and show a seasonal variation with lower values during the winter when the ground is often covered by snow. Potassium may be derived from soils, but is also a component of smoke.

Other elements are considered tracers of various industrial and urban activities. Lead and bromine, for example, result from automobile emissions. Annual concentrations of lead at IMPROVE sites in the mid-Atlantic states are commonly in the range of 2 to $6 \mathrm{ng} / \mathrm{m}^{3}$, or up to 10 times higher than at the two southeast Idaho sites. Selenium, in the $0.2 \mathrm{ng} / \mathrm{m}^{3}$ range at Craters of the Moon and CFA, is a tracer of emissions from coal-fired plants. At Mammoth Cave in Kentucky, annual selenium concentrations of $1.4 \mathrm{ng} / \mathrm{m}^{3}$ have been reported [Reference 5-3].

Fine particles with a diameter less than 2.5 micrometers, $\mathrm{PM}_{2.5}$, are the size fraction most commonly associated with visibility impairment. At Craters of the Moon, $\mathrm{PM}_{2.5}$ has ranged over the period of sampler operation from 0.4 to $25 \mu \mathrm{g} / \mathrm{m}^{3}$ with a mean of $3.7 \mu \mathrm{g} / \mathrm{m}^{3}$.

Concentrations at CFA during the same time period varied from 0.5 to $28 \mu \mathrm{g} / \mathrm{m}^{3}$, with a mean of $4.4 \mu \mathrm{g} / \mathrm{m}^{3}$. In general, the highest levels of very fine mass have been seen during the late summer and early fall, particularly in 1994, when smoke from western forest fires covered the Snake River Plain (Figure 5-3). Elevated very fine mass concentrations are also found occasionally during wintertime inversion conditions, most notably during January 1993 at CFA. 


\begin{tabular}{|c|c|c|c|c|c|c|}
\hline \multirow[b]{3}{*}{ Constituent } & \multicolumn{6}{|c|}{$\begin{array}{l}\text { TABLE 5-3. DATA FOR IMPROVE SAMPLERS AT CFA AND } \\
\text { CRATERS OF THE MOON NATIONAL MONUMENT (MAY 1992 - May 1997)a }\end{array}$} \\
\hline & \multicolumn{2}{|c|}{$\%$ Detected $^{b}$} & \multicolumn{2}{|c|}{ Range } & \multicolumn{2}{|c|}{ Mean $^{c}$} \\
\hline & $\mathrm{CFA}$ & Craters & $\mathrm{CFA}$ & Craters & CFA & Craters \\
\hline$\overline{\text { Hydrogen }}$ & 100 & 100 & $24-1256$ & $19 \cdot 1339$ & $17 \overline{4 \pm 12}$ & $\overline{150+9}$ \\
\hline Sodium & 40 & 68 & $<\mathrm{dl}^{\mathrm{d}}-214$ & $<\mathrm{dl}-257$ & $35 \pm 3$ & $40 \pm 3$ \\
\hline Magnesium & 31 & 26 & $<\mathrm{dl}-399$ & $<\mathrm{dl}-145$ & $18 \pm 3$ & $12 \pm 1$ \\
\hline Aluminum & 58 & 74 & $<\mathrm{dl}-1146$ & $<\mathrm{dl}-965$ & $58 \pm 10$ & $51 \pm 7$ \\
\hline Silicon & 77 & 99 & $<\mathrm{dl}-2869$ & $<\mathrm{dl}-2115$ & $167 \pm 27$ & $132 \pm 16$ \\
\hline Phosphorus & 13 & 9 & $<\mathrm{dl}-120$ & $<\mathrm{dl}-103$ & $5.4 \pm 0.9$ & $4.0 \pm 0.7$ \\
\hline Sulfur & 78 & 81 & $23-1509$ & $16-678$ & $198 \pm 12$ & $163 \pm 9$ \\
\hline Chlorine & 4.4 & 5.5 & $<\mathrm{dl}-37$ & $<\mathrm{dl}-15$ & $2.7 \pm 0.3$ & $2.4 \pm 0.1$ \\
\hline Potassium & 77 & 98 & $<\mathrm{dl}-468$ & $<\mathrm{d} 1-447$ & $41 \pm 5$ & $36 \pm 4$ \\
\hline Calcium & 77 & 97 & $<\mathrm{dl}-880$ & $<\mathrm{d} 1-295$ & $51 \pm 6$ & $40 \pm 4$ \\
\hline Titanium & 60 & 80 & $<\mathrm{dl}-75$ & $<\mathrm{d} l-48$ & $4.6 \pm 0.6$ & $3.4 \pm 0.4$ \\
\hline Vanadium & 31 & 34 & $<\mathrm{dl}-7.0$ & $<\mathrm{dl}-5.0$ & $1.3 \pm 0.1$ & $0.9 \pm 0.1$ \\
\hline Chromium & 20 & 27 & $<\mathrm{dl}-4.1$ & $<\mathrm{dl}-5: 3$ & $0.8 \pm 0.04$ & $0.85 \pm 0.04$ \\
\hline Manganese & 36 & 45 & $<\mathrm{dl}-15$ & $<\mathrm{dl}-11$ & $1.3 \pm 0.1$ & $1.2 \pm 0.1$ \\
\hline Iron & 78 & 100 & $1-706$ & $1-410$ & $38 \pm 6$ & $31 \pm 3$ \\
\hline Nickel & 13 & 14 & $<\mathrm{dl}-0.4$ & $<\mathrm{dl}-1.1$ & $0.066 \pm 0.003$ & $0.07 \pm 0.005$ \\
\hline Copper & 75 & 83 & $<\mathrm{dl}-5.9$ & $<\mathrm{dl}-6.4$ & $0.6 \pm 0.06$ & $0.5 \pm 0.05$ \\
\hline Zinc & 78 & 100 & $0-29$ & $0-20$ & $1.8 \pm 0.2$ & $1.3 \pm 0.1$ \\
\hline Arsenic & 32 & 35 & $<\mathrm{dl}-1.7$ & $<\mathrm{dl}-4.1$ & $0.18 \pm 0.02$ & $0.20 \pm 0.02$ \\
\hline Lead & 67. & 93 & $<\mathrm{dl}-3.0$ & $<\mathrm{dl}-4.4$ & $0.58 \pm 0.03$ & $0.62 \pm 0.04$ \\
\hline Selenium & 67 & 58 & $<\mathrm{dl}-2.3$ & $<\mathrm{dl}-1.1$ & $0.22 \pm 0.02$ & $0.15 \pm 0.01$ \\
\hline Bromine & 78 & 81 & $0.2-8.3$ & $0.2-6.0$ & $1.5 \pm 0.1$ & $1.3 \pm 0.1$ \\
\hline Rubidium & 56 & 57 & $<\mathrm{d} 1-1.4$ & $<\mathrm{dl}-1.1$ & $0.15 \pm 0.02$ & $0.11 \pm 0.01$ \\
\hline Strontium & 58 & 70 & $<\mathrm{d} l-7.2$ & $<\mathrm{dl}-12$ & $0.25 \pm 0.02$ & $0.26 \pm 0.05$ \\
\hline Zirconium & 17 & 16 & $<\mathrm{dl}-2.0$ & $<\mathrm{dl}-1.7$ & $0.15 \pm 0.01$ & $0.15 \pm 0.01$ \\
\hline Molybdenum & 4.5 & 3.7 & $<\mathrm{dl}-3.3$ & $<\mathrm{dl}-3.8$ & $1.3 \pm 0.1$ & $1.3 \pm 0.1$ \\
\hline $\begin{array}{l}\text { Hnits expr } \\
\text { " Percentage } \\
\text { Arithmetic } \\
\text { A At least on }\end{array}$ & gran & $\begin{array}{l}\text { nce in } \\
\text { tion lir }\end{array}$ & mean. & that par: & 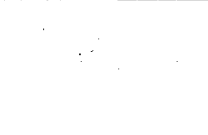 & \\
\hline
\end{tabular}

\subsection{STORM WATER MONITORING}

The National Pollutant Discharge Elimination System (NPDES) General Permit sets monitoring requirements for three types of facilities which are directly applicable to the INEEL: (1) Emergency Planning and Community Right to Know Act (EPCRA) Section 313 facilities, (2) coal piles, and (3) land disposal units, incinerators, boilers, and industrial furnaces. Additional monitoring locations are sampled for characterization purposes to evaluate the effectiveness of pollution abatement programs.

The Idaho Nuclear Technology and Engineering Center (INTEC) qualifies as a EPCRA Section 313 Facility because of the quantity of nitric acid used at the plant. For INTEC, the water priority chemical is nitric acid, and the monitor- ing parameters are $\mathrm{pH}$, nitrate plus nitrite, oil and grease, biological oxygen demand (BOD), chemical oxygen demand (COD), total suspended solids (TSS), total Kjeldahl nitrogen (TKN), total phosphorous, and acute whole effluent toxicity.

An industrial coal pile for steam generation is also located at the INTEC. The NPDES General Permit lists parameters which must be monitored in storm water discharges from coal piles as: oil and grease, $\mathrm{pH}$, TSS, copper, nickel, and zinc.

The Central Facilities Area (CFA) Landfill III, the Subsurface Disposal Area (SDA) at the Radioactive Waste Management Area Complex (RWMC), and the Waste Experimental Reduction Facility (WERF) incinerator all require monitoring. Land disposal units and incinerators require monitoring for oil $\&$ grease, $\mathrm{pH}$, chemical 


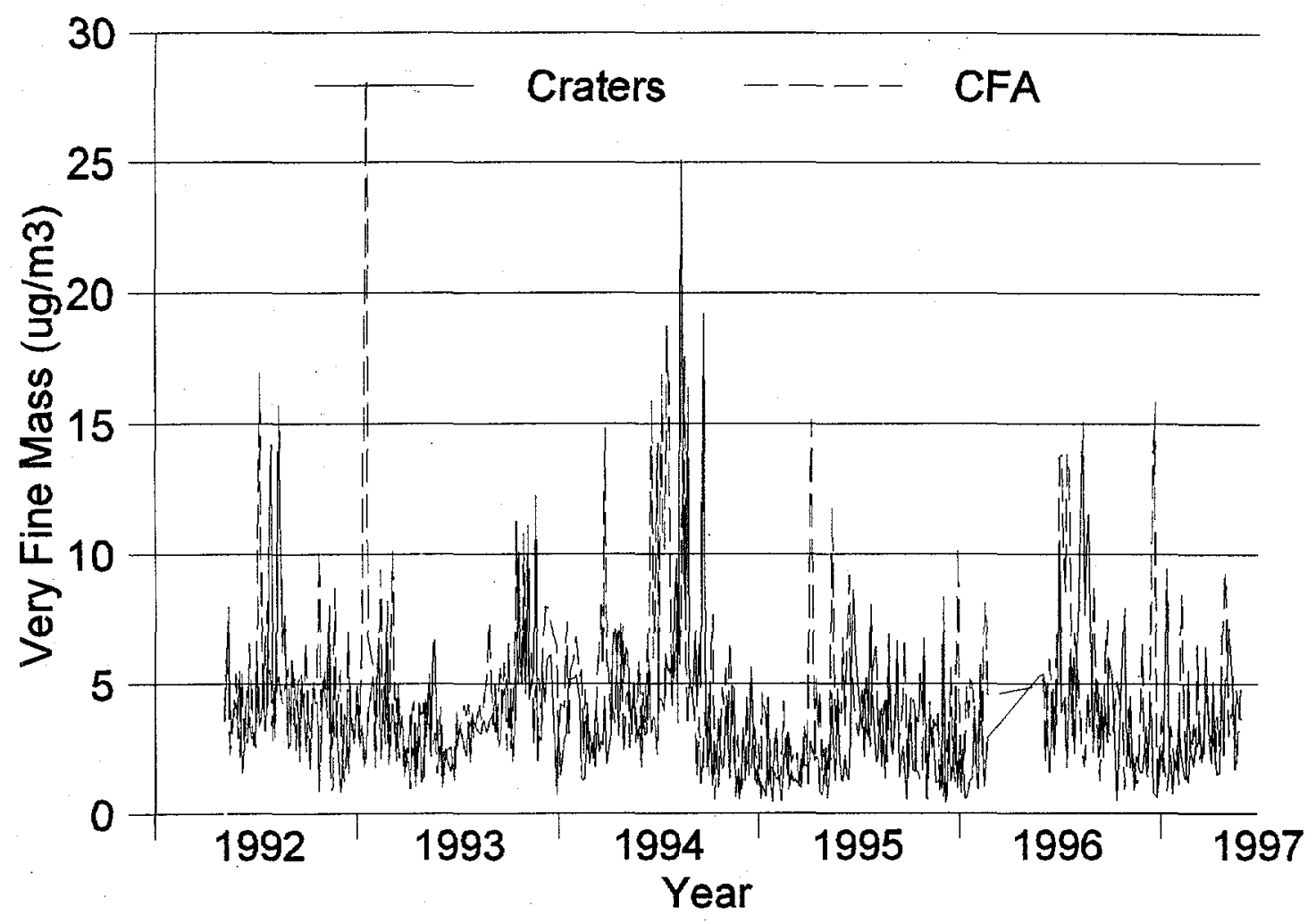

Figure 5-3. Very fine mass $\left(\mathrm{PM}_{2.5}\right)$ at Craters of the Moon and CFA (1992-1997)

oxygen demand (COD), acute whole effluent toxicity, TKN, total and dissolved magnesium, total dissolved solids, total organic carbon, arsenic, barium, cadmium, chromium, cyanide, lead, mercury, selenium, and silver.

The INEEL Storm Water Monitoring program was redesigned in 1997 on the recommendations of an independent evaluation of previous monitoring efforts, regulations, other DOE programs, and historical storm water monitoring data. The number of storm water monitoring points was reduced from 21 to 16 . In 1997, six of the 16 points were sampled during one or more of three different snow melt and/or storm events. The results of this sampling are given in Table 54. Benchmarks for the storm water monitoring parameters specified in the NPDES General Permit are also listed in Table 5-4.

Three samples exhibited concentrations of one or more of the measured parameters exceeding the corresponding benchmark. A sample collected at the RWMC on January 2, 1997, contained concentrations of zinc and TSS exceeding the respective benchmarks. Another sample collected at the same location on June 10, 1997, contained concentrations of TSS, zinc, iron, and nitrogen (nitrate plus nitrite) in excess of the benchmarks. A sample collected at WERF on January 2, 1997, exhibited a total phosphorous concentration in excess of the NPDES benchmark, and a sample collected at the INTEC on June 10, 1997, contained TSS in excess of the benchmark.

While Table 5-4 lists several analyses in which the sample concentrations exceeded the respective benchmarks, the only permit-required limits at the INEEL are for $\mathrm{pH}$ in runoff from the coal piles at the INTEC, and in 1997 all of the samples had values within the specified limits of $\mathrm{pH} 6$ to 9. The benchmarks in Table 5-4, according to the 1995 NPDES General Permit 
[Reference 5-4], are not effluent limits; rather they are performance targets above which there is a level of concern. The level of concern is a concentration at which a storm water discharge might impair water quality or affect human health from ingestion of water or fish. These levels have been used by EPA to determine if a storm water discharge from a given facility merits further monitoring. Exceeding the benchmarks does not necessarily imply water quality violations in the receiving water body, especially in cases like the NNEEL, where in 1997, the RWMC was the only location with a discharge which could eventually reach a water body of concern (the Big Lost River). The NPDES General Permit is concerned with Waters of the U.S., water bodies used for purposes that could affect interstate commerce or recreation. In this case, water quality in the Big Lost River was not affected because the discharge infiltrated in the manmade channel within a short distance of the discharge point.

\begin{tabular}{|c|c|c|c|c|c|}
\hline \multicolumn{6}{|c|}{$\begin{array}{c}\text { TABLE 5-4. } \\
\text { NONRADIOLOGICAL } \\
\text { STORM WATER MONITORING DATA (1997) }\end{array}$} \\
\hline $\begin{array}{c}\text { Monitoring } \\
\text { Point }\end{array}$ & Parameter & $\begin{array}{l}\text { Avg. } \\
\text { Conc. }\end{array}$ & $\begin{array}{l}\text { Max. } \\
\text { Conc. }\end{array}$ & Units & $\begin{array}{c}\text { NPDES } \\
\text { Benchmark }\end{array}$ \\
\hline RWMC & Conductivity & 82.50 & 91.00 & $\overline{\mathrm{mS}}$ & NA \\
\hline WMC-MP-2 & $\mathrm{pH}$ & 7.64 & 8.02 & & $6.0-9.0$ \\
\hline & Biological Oxygen Demand (5-day) & 4.50 & 5.00 & $\mathrm{mg} / \mathrm{L}$ & 30 \\
\hline & Chemical Oxygen Demand & 53.75 & 64.50 & $\mathrm{mg} / \mathrm{L}$ & 120 \\
\hline & Nitrogen (Nitrate + Nitrite) & 0.185 & 0.23 & $\mathrm{mg}-\mathrm{N} / \mathrm{L}$ & $0.68 * *$ \\
\hline & Total Phosphorous & 0.640 & 0.640 & $\mathrm{mg} / \mathrm{L}$ & 2.0 \\
\hline & Total Dissolved Solids & 109.00 & 120.00 & $\mathrm{mg} / \mathrm{L}$ & NA \\
\hline & Total Kjeldahl Nitrogen & 3.10 & 4.20 & $\mathrm{mg} / \mathrm{L}$ & NA \\
\hline & Total Organic Carbon & 5.15 & 5.20 & $\mathrm{mg} / \mathrm{L}$ & NA \\
\hline & Total Oil and Grease & 1.90 & 3.30 & $\mathrm{mg} / \mathrm{L}$ & 15 \\
\hline & Total Suspended Solids & 220.00 & 421.00 & $\mathrm{mg} / \mathrm{L}$ & $100 * *$ \\
\hline & Barium & 0.196 & 0.316 & $\mathrm{mg} / \mathrm{L}$ & na \\
\hline & Calcium & 27.20 & 27.20 & $\mathrm{mg} / \mathrm{L}$ & na \\
\hline & Cadmium & 0.005 & 0.009 & $\mathrm{mg} / \mathrm{L}$ & 0.016 \\
\hline & Chromium & 0.016 & 0.029 & $\mathrm{mg} / \mathrm{L}$ & NA \\
\hline & Copper & 0.021 & 0.031 & $\mathrm{mg} / \mathrm{L}$ & 0.064 \\
\hline & Iron & 1.29 & 1.29 & $\mathrm{mg} / \mathrm{L}$ & $1.0 * *$ \\
\hline & Mercury & 0.00017 & 0.00029 & $\mathrm{mg} / \mathrm{L}$ & 0.0024 \\
\hline & Potassium & 11.60 & 11.60 & $\mathrm{mg} / \mathrm{L}$ & NA \\
\hline & Magnesium & 5.83 & 9.35 & $\mathrm{mg} / \mathrm{L}$ & NA \\
\hline & Magnesium Soluble & 5.73 & 9.34 & $\mathrm{mg} / \mathrm{L}$ & NA \\
\hline & Manganese & 0.060 & 0.060 & $\mathrm{mg} / \mathrm{L}$ & 1.0 \\
\hline & Sodium & 7.59 & 7.59 & $\mathrm{mg} / \mathrm{L}$ & NA \\
\hline & Nickel & 0.017 & 0.029 & $\mathrm{mg} / \mathrm{L}$ & 1.4 \\
\hline & Vanadium & 0.039 & 0.039 & $\mathrm{mg} / \mathrm{L}$ & NA \\
\hline & Zinc & 0.282 & 0.421 & $\mathrm{mg} / \mathrm{L}$ & $0.117 * *$ \\
\hline & Discharge & & 6000 & $\mathrm{gal}$ & NA \\
\hline
\end{tabular}




\begin{tabular}{|c|c|c|c|c|c|}
\hline & $\begin{array}{r}\text { TABLE 5-4. } \\
\text { NONRADIO } \\
\text { STORM WATER MON }\end{array}$ & $\begin{array}{l}\text { Continu } \\
\text { OGICA } \\
\text { CORINS }\end{array}$ & ATAC & & \\
\hline $\begin{array}{c}\text { Monitoring } \\
\text { Point }\end{array}$ & Parameter & $\begin{array}{l}\text { Min. } \\
\text { Conc. }\end{array}$ & $\begin{array}{l}\text { Max. } \\
\text { Conc. }\end{array}$ & Units & $\begin{array}{c}\text { NPDES } \\
\text { Benchmark }\end{array}$ \\
\hline WERF & Conductivity & 50.00 & 50.00 & $\mathrm{mS}$ & NA \\
\hline WRF-MP-1 & $\mathrm{pH}$ & 7.20 & 7.20 & & $6.0-9.0$ \\
\hline & Chemical Oxygen Demand & 47.20 & 47.20 & $\mathrm{mg} / \mathrm{L}$ & 120 \\
\hline & Nitrogen as Ammonia & 4.10 & 4.10 & $\mathrm{mg} / \mathrm{L}$ & $\mathrm{NA}$ \\
\hline & Total Phosphorous & 1.60 & 1.60 & $\mathrm{mg} / \mathrm{L}$ & 2.0 \\
\hline & Total Dissolved Solids & 93.00 & 93.00 & $\mathrm{mg} / \mathrm{L}$ & NA \\
\hline & Tot. Kjeldahl Nitrogen & 8.90 & 8.90 & $\mathrm{mg} / \mathrm{L}$ & NA \\
\hline & Total Organic Carbon & 14.40 & 14.40 & $\mathrm{mg} / \mathrm{L}$ & NA \\
\hline & Total Oil and Grease & 4.10 & 4.10 & $\mathrm{mg} / \mathrm{L}$ & 15 \\
\hline & Total Suspended Solids & 53.00 & 53.00 & $\mathrm{mg} / \mathrm{L}$ & 100 \\
\hline & Barium & 0.034 & 0.034 & $\mathrm{mg} / \mathrm{L}$ & $\mathrm{NA}$ \\
\hline & Chromium & 0.007 & 0.007 & $\mathrm{mg} / \mathrm{L}$ & $\mathrm{NA}$ \\
\hline & Copper & 0.014 & 0.014 & $\mathrm{mg} / \mathrm{L}$ & 0.064 \\
\hline & Zinc & 0.050 & 0.050 & $\mathrm{mg} / \mathrm{L}$ & 0.117 \\
\hline WERF & Conductivity & 26.00 & 26.00 & $\mathrm{mS}$ & $\mathrm{NA}$ \\
\hline WRF-MP-2 & $\mathrm{pH}$ & 7.10 & 7.10 & & $6.0-9.0$ \\
\hline & Chemical Oxygen Demand & 26.20 & 26.20 & $\mathrm{mg} / \mathrm{L}$ & 120 \\
\hline & Nitrogen as Ammonia & 1.80 & 1.80 & $\mathrm{mg} / \mathrm{L}$ & NA \\
\hline & Total Phosphorous & 8.70 & 8.70 & $\mathrm{mg} / \mathrm{L}$ & $2.0 * *$ \\
\hline & Total Dissolved Solids & 67.00 & 67.00 & $\mathrm{mg} / \mathrm{L}$ & NA \\
\hline & Total Kjeldahl Nitrogen & 2.90 & 2.90 & $\mathrm{mg} / \mathrm{L}$ & $\mathrm{NA}$ \\
\hline & Total Organic Carbon & 6.10 & 6.10 & $\mathrm{mg} / \mathrm{L}$ & NA \\
\hline & Total Oil and Grease & 1.80 & 1.80 & $\mathrm{mg} / \mathrm{L}$ & 15 \\
\hline & Total Suspended Solids & 11.00 & 11.00 & $\mathrm{mg} / \mathrm{L}$ & 100 \\
\hline & Barium & 0.096 & 0.096 & $\mathrm{mg} / \mathrm{L}$ & $\mathrm{NA}$ \\
\hline & Chromium & 0.008 & 0.008 & $\mathrm{mg} / \mathrm{L}$ & NA \\
\hline & Copper & 0.007 & 0.007 & $\mathrm{mg} / \mathrm{L}$ & 0.064 \\
\hline & Lead & 0.037 & 0.037 & $\mathrm{mg} / \mathrm{L}$ & 0.082 \\
\hline & Zinc & 0.078 & 0.078 & $\mathrm{mg} / \mathrm{L}$ & 0.117 \\
\hline INTEC & Conductivity & 43.00 & 43.00 & $\mathrm{mS}$ & $\mathrm{NA}$ \\
\hline CPP-MP-1 & $\mathrm{pH}$ & 6.93 & 6.93 & & $6.0-9.0$ \\
\hline & Biochemical Oxygen Demand (5-day) & 4.00 & 4.00 & $\mathrm{mg} / \mathrm{L}$ & 30 \\
\hline & Chemical Oxygen Demand & 6.50 & 6.50 & $\mathrm{mg} / \mathrm{L}$ & 120 \\
\hline & Nitrogen (Nitrate + Nitrite) & 0.490 & 0.490 & $\mathrm{mg}-\mathrm{N} / \mathrm{L}$ & 0.68 \\
\hline & Total Phosphorous & 1.20 & 1.20 & $\mathrm{mg} / \mathrm{L}$ & 2.0 \\
\hline & Total Kjeldahl Nitrogen & 1.10 & 1.10 & $\mathrm{mg} / \mathrm{L}$ & NA \\
\hline & Total Oil and Grease & 1.40 & 1.40 & $\mathrm{mg} / \mathrm{L}$ & 15 \\
\hline & Total Suspended Solids & 360 & 360 & $\mathrm{mg} / \mathrm{L}$ & $100 * *$ \\
\hline
\end{tabular}




\begin{tabular}{|c|c|c|c|c|c|}
\hline & $\begin{array}{r}\text { TABLE 5-4. } \\
\text { NONRADIO } \\
\text { STORM WATER MON }\end{array}$ & $\begin{array}{l}\text { Continu } \\
\text { OGIC } \\
\text { CORIN }\end{array}$ & AATA & & \\
\hline $\begin{array}{c}\text { Monitoring } \\
\text { Point } \\
\end{array}$ & Parameter & $\begin{array}{l}\text { Min. } \\
\text { Conc. }\end{array}$ & $\begin{array}{l}\text { Max. } \\
\text { Conc. }\end{array}$ & Units & $\begin{array}{c}\text { NPDES } \\
\text { Benchmark }\end{array}$ \\
\hline INTEC & Conductivity & 41.00 & 41.00 & $\mathrm{mS}$ & NA \\
\hline CPP-MP-2 & $\mathrm{pH}$ & 6.98 & 6.98 & & $6.0-9.0$ \\
\hline & Chemical Oxygen Demand & 24.00 & 24.00 & $\mathrm{mg} / \mathrm{L}$ & 120 \\
\hline & Total Oil and Grease & 1.90 & 1.90 & $\mathrm{mg} / \mathrm{L}$ & 15 \\
\hline & Total Suspended Solids & 53.00 & 53.00 & $\mathrm{mg} / \mathrm{L}$ & 100 \\
\hline & Copper & 0.007 & 0.007 & $\mathrm{mg} / \mathrm{L}$ & 0.064 \\
\hline & Zinc & 0.018 & 0.018 & $\mathrm{mg} / \mathrm{L}$ & 0.1170 \\
\hline $\mathrm{SMC} /$ & Conductivity & 82.50 & 91.00 & $\mathrm{mS}$ & $\mathrm{NA}$ \\
\hline TAN & $\mathrm{pH}$ & 7.64 & 8.02 & & $6.0-9.0$ \\
\hline SMC-MP-1 & Biochemical Oxygen Demand (5-day) & 4.50 & 5.00 & $\mathrm{mg} / \mathrm{L}$ & 30 \\
\hline & Chemical Oxygen Demand & 53.75 & 64.50 & $\mathrm{mg} / \mathrm{L}$ & 120 \\
\hline & Nitrogen (Nitrate + Nitrite) & 0.185 & 0.230 & $\mathrm{mg}-\mathrm{N} / \mathrm{L}$ & 0.68 \\
\hline & Total Oil and Grease & 1.15 & 1.80 & $\mathrm{mg} / \mathrm{L}$ & 15 \\
\hline & Total Suspended Solids & 10.65 & 14.30 & $\mathrm{mg} / \mathrm{L}$ & 100 \\
\hline
\end{tabular}




\section{Summary of Chapter 6 Ground Water}

The Snake River Plain Aquifer, a primary source for drinking water and crop irrigation in southeastern Idaho, flows beneath the Idaho National Engineering and Environmental Laboratory (INEEL). The U.S. Geological Survey (USGS) maintains observation wells in the INEEL vicinity to monitor the movement of radiochemical and chemical substances in this aquifer, and in overlying perched aquifers and surface water bodies (Section 6.1). Lockheed Martin Idaho Technologies Company (LMITCO) also conducts ground-water monitoring for compliance at the INEEL. The status of the tritium and ${ }^{90} \mathrm{Sr}$ contaminant plumes is updated based on data collected during 1992-95. The extent of the tritium contaminant plume, originating from the Test Reactor Area (TRA) and the Idaho Nuclear Technology and Engineering Center (INTEC) remained about the same as it was in 1991. However, concentrations in well water within the plume significantly decreased. This is attributed to radioactive decay and a decrease in tritium disposal rates (Section 6.1). The extent of the ${ }^{90} \mathrm{Sr}$ contaminant plume, originating from INTEC, as well as the concentrations of ${ }^{90} \mathrm{Sr}$ have remained essentially constant since 1991 . This is attributed to a lack of ground-water recharge from the Big Lost River and to chemical changes in the ground water due to the disposal of chemicals in the INTEC infiltration ponds (Section 6.1).

In addition to routine monitoring, the USGS publishes the results of a variety of special studies detailing characteristics and conditions in the aquifer. Some of the documents issued during 1997 included (1) reports on long-term studies of the aquifer, both on the INEEL and in the region between the INEEL and the aquifer discharge points along the middle reach of the Snake River; (2) a report detailing the continuing study of the stratigraphy of the aquifer rocks; (3) a report estimating the extent of surface flooding which could be caused by a hypothetical 100-year peak flow in streams entering the INEEL; and (4) a report describing measurements of strontium-related ion-exchange properties of INEEL surficial sediments. These reports are summarized in Section 6.1 of this chapter.

The USGS and contractors who operate the various facilities at the INEEL perform routine monitoring of the ground water under and adjacent to the site. Results of groundwater monitoring conducted during 1997 are summarized in this chapter. Elevated concentrations of several purgeable (volatile) organic chemicals continue to be present in some wells in the vicinity of INEEL facilities (Section 6.2). Trichloroethylene concentrations at the wellhead of Well TSF\#1 at Test Area North (TAN) remained greater than the USEPA drinking water standards. However, a new sparger aeration system reduced trichloroethylene concentrations within the TAN drinking water distribution system to levels below the drinking water maximum contaminant level in 1997.

All gross alpha and gross beta concentrations in onsite production wells were less than drinking water standards (Section 6.3). Tritium concentrations continued to be present in two production wells and three drinking water distribution systems, but concentrations met drinking water standards and are decreasing. Strontium-90, occasionally detected in production wells at one INEEL facility, was not detected in the 1997 samples. No coliform bacteria were detected in any INEEL potable water samples. (Section 6.4) 



\section{Ground Water}

\subsection{AQUIFER STUDIES}

\section{Program Information}

USGS. The USGS is responsible for conducting ground-water monitoring, analyses, and studies of the Snake River Plain Aquifer under and adjacent to the INEEL. This is done through an extensive network of strategically placed observation wells on and near the Site (Figures 6-1 and 6-2). The Snake River Plain Aquifer, which travels beneath the INEEL, serves as one of the primary sources for drinking water and crop irrigation in the Snake River Basin. A brief description of the hydrogeology of the INEEL and the movement of water in the Snake River Plain Aquifer was given in Chapter 1. Further information may be found in USGS publications.

The USGS has investigated hydrologic conditions at the INEEL since 1949, and currently conducts an extensive monitoring program for the aquifer and perched water bodies above it. This program includes collection of samples on the INEEL and at locations beyond the southern and western boundaries. The USGS routine groundwater surveillance program was summarized in Chapter 3. In 1997, the routine program included collection of 376 samples for radionuclides and inorganic constituents including trace elements, and 66 samples for purgeable organic compounds. In addition, as part of the 1997 NRF sampling program, the USGS collected 45 samples from 13 NRF wells sampled quarterly for radioactivity, inorganic constituents, and purgeable organic compounds. Samples for the first quarter were collected by the contractor at NRF.

Various USGS reports contain maps showing the frequency of water level measurements and water sample collections. Recent information has also been published on the shape and extent of contaminant plumes (the spread of various contaminants in the water of the aquifer and perched water from INEEL facilities) between 1992 and 1995 [Reference 6-1]. A summary of this information is presented in this section.

The USGS also conducts special studies of the ground water of the Snake River Plain. A summary of these studies is provided in this section. These special studies provide more specific geological, chemical, and hydrological information on the flow and recharge of the aquifer and the movements of radiochemical and chemical substances in the ground water. Most of the information from these studies is published in USGS reports.

Results of recently published monitoring or surveillance activities are summarized in the Annual Site Environmental Report during the year of publication, but may refer to sampling programs that took place in earlier years. USGS results are available upon request from the USGS INEEL Project Office; this office can also provide information for securing copies of their reports.

LMITCO. LMITCO conducts ground-water monitoring in support of Wastewater Land Application Permit requirements at INTEC and TAN, as well as surveillance monitoring at INTEC. More detailed information and data will be included in the 1997 LMITCO Environmental Monitoring Program Report for the Idaho National Engineering and Environmental Laboratory, INEEL/EXT-98-00305, due to be published in August 1998. 


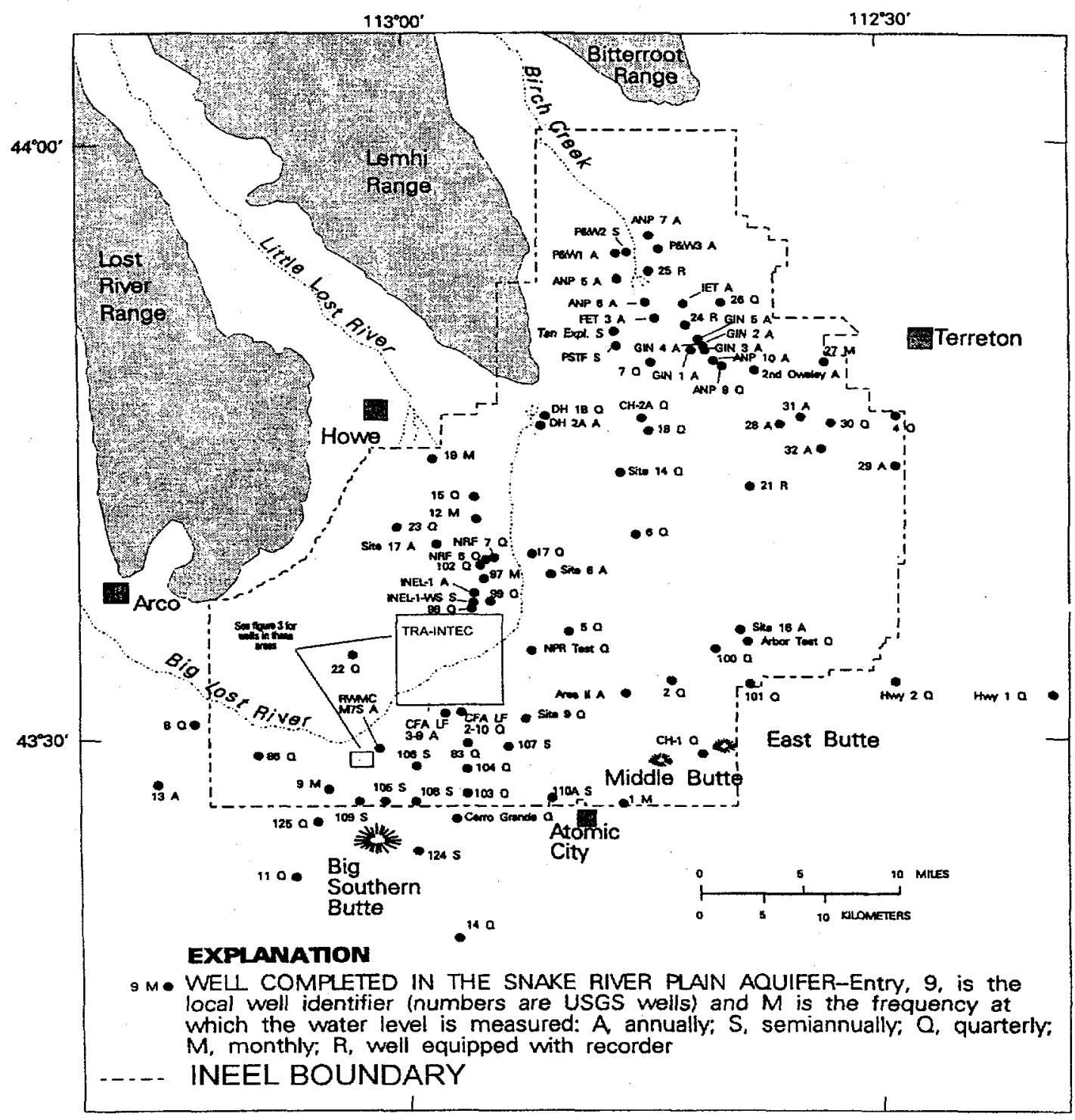

Figure 6-1. USGS Well Locations

Summary of USGS Special Studies

Evaluation of Radionuclide, Inorganic Constituent, and Organic Compound Data from Selected Wells and Springs from the Southern Boundary of the Idaho National Engineering Laboratory to the Hagerman Area, Idaho, 1989 through 1992

[Reference 6-2]
Water quality data collected from 55 wells and springs downgradient from the INEEL southern boundary to the Hagerman area from 1989 through 1992 was evaluated. Water samples collected during this period were analyzed for selected radionuclides, inorganic constituents, and organic compounds. A statistical comparison between data collected in 1989 and data collected in 1990-1992, together with a comparison of replicate pairs, was used to evaluate changes 

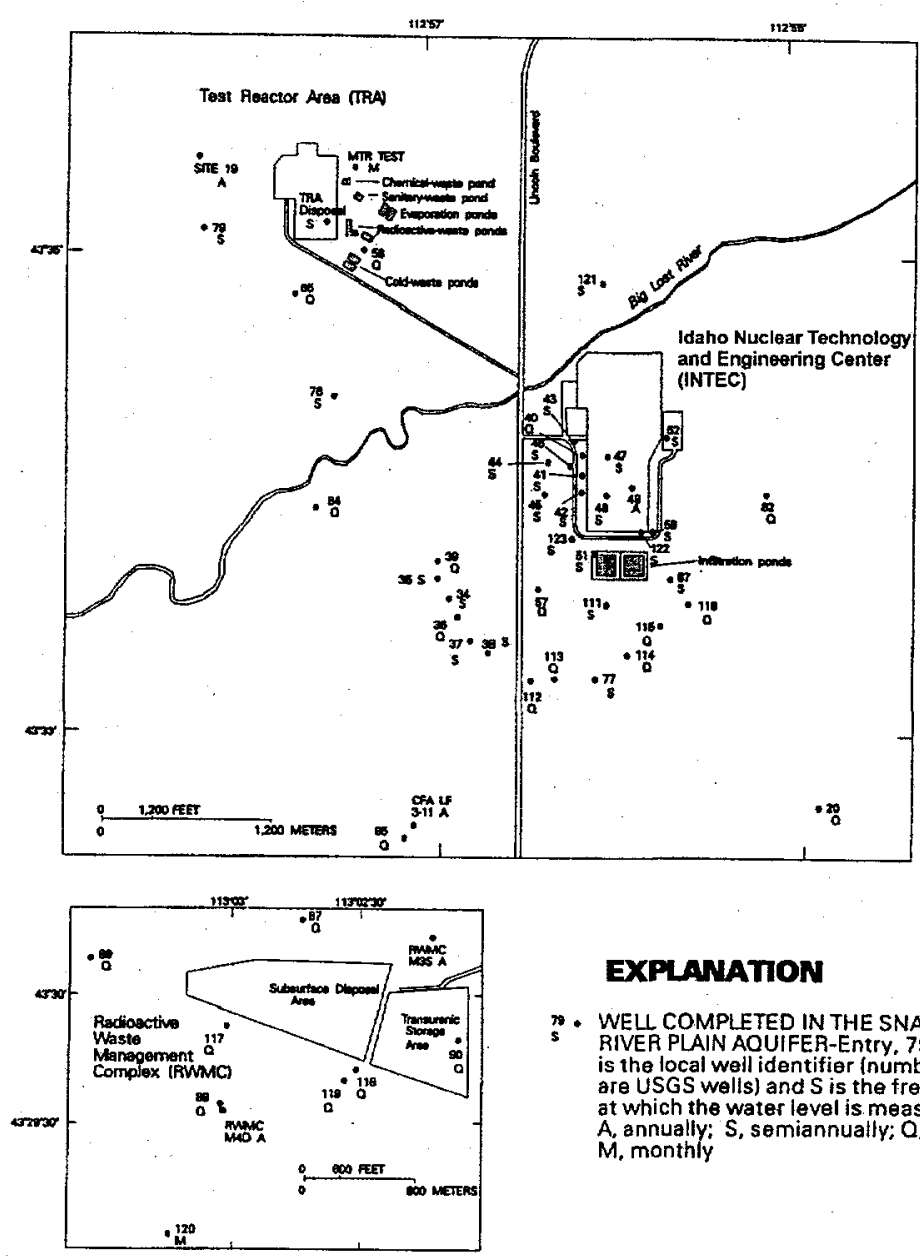

* WEL COMPLETED IN THE SNAKE

RIVER PLAIN AQUIFER-Entry, 79 , is the local well identifier (numbers are USGS wells) and $S$ is the frequency at which the water level is measured: $A$ annually: S, semiannually; 0 , quarterly $M$, monthly

\section{Figure 6-2. USGS Well Locations at INTEC-TRA and RWMC}

in water quality between samples and to assess sampling and analysis precision for individual constituents.

Comparisons of radionuclide data showed no pattern of water quality change with time as concentrations randomly increased or decreased. Tritium concentrations did show a consistent pattern with location in the aquifer. The highest tritium concentrations occurred in water from wells in the Big Wood and Little Wood River drainages and in the southern part of the study area where heavy irrigation occurs.

For most of the inorganic constituent data, comparisons showed no statistically significant changes with time between samples at a given location. Exceptions included data for nitrite plus nitrate as nitrogen and orthophosphate as phosphorous. Nitrite plus nitrate concentrations showed a consistent pattern with location as concentrations were higher in agricultural areas than in rangeland areas.

Most organic compound data showed no statistically significant changes between successive samples. Comparisons of replicate pairs showed generally good data reproducibility; for radionuclides and organic and inorganic constituents.

\section{Simulation of Water- Surface Elevations for a Hypothetical 100-Year Peak Flow in Birch Creek at the Idaho National Engineering and Envir- onmental Laboratory, Idaho. [Reference 6-3]}

In the final phase of a three-phase study, a floodplain model of Birch Creek was developed, and the flow capacity of diversions was estimated. The model simulated a hypothetical 100year peak flow in Birch Creek and calculated corresponding water-surface elevations along surveyed cross-sections at the INEEL. The simulated water-surface elevations were then used to delineate the areal extent of flooding caused by the hypothetical 100-year peak flow.

Birch Creek flows southward about $65 \mathrm{~km}$ (40 miles) through an alluvium-filled valley onto the northern part of the INEEL site on the eastern Snake River Plain. The lower 16 km (10-mile) 
reach of Birch Creek is of particular concern; it ends in Birch Creek Playa near several INEEL facilities.

Dikes surround two of the facilities in and around the playa. At the elevation at the top of the dikes, Birch Creek Playa has a volume of $2.66 \times 10^{7} \mathrm{~m}^{3}$ (21,600 acre-feet), greater than the volume of the $1.60 \times 10^{7} \mathrm{~m}^{3}$ (13,000 acre-feet) that would be generated by the hypothetical 100 year peak flow. The water-surface elevation resulting from a volume of $1.60 \times 10^{7} \mathrm{~m}^{3}$ $(13,000$ acre-feet) is about $0.6 \mathrm{~m}$ ( 2 feet) lower than the elevation of the dikes; therefore, no flooding of the facilities would be expected from the hypothetical 100-year peak flow.

The exact location of flood boundaries on Birch Creek could not be determined because of the highly braided channel and the many anthropogenic features (such as the trench, highway, and diversion channels) in the study area that affect flood hydraulics and flow. Because flood boundaries could not be located exactly, only a generalized flood-prone map was developed. Upstream from Highway 22, peak flows were confined within the braided channels. At Highway 22 and downstream, flows spread out, probably due to the anthropogenic features. If the anthropogenic features were not present, peak flows would probably be confined within the braided channels of Birch Creek.

Preliminary Delineation of Natural Geochemical Reactions, Snake River Plain Aquifer System, Idaho National Engineering Laboratory and Vicinity, Idaho. [Reference 6-4]

As part of a study to determine the natural geochemistry of the Snake River Plain aquifer system at the INEEL, a group of reactions were identified which partially control ground-water chemistry. Mineralogy of the aquifer matrix was determined using $\mathrm{X}$-ray diffraction and thinsection analysis, and theoretical stabilities of the minerals were used to identify potential solidphase reactants and products of the reactions.
The reactants and products which have an important contribution to the natural geochemistry include labradorite, olivine, pyroxene, smectite, calcite, ferric oxyhydroxide, and several silica phases.

To further identify the reactions, analyses of 22 representative water samples from sites tapping the Snake River Plain aquifer system were used to determine the thermodynamic condition of the ground water relative to the minerals of the aquifer system. Principal reactions modifying the natural geochemical system include congruent dissolution of olivine, diopside, amorphous silica, and anhydrite; incongruent dissolution of labradorite with calcium montmorillonite as a residual product; precipitation of calcite and ferric oxyhydroxide; and oxidation of ferrous iron to ferric iron.

The geochemistry outlined in this report strongly influences the movement of radionuclides in ground water. In particular, cation exchange reactions retard the downward movement of heavy, multivalent waste constituents where infiltration ponds are used for waste disposal.

\section{Strontium Distribution Coefficients of Surficial Sediment Samples from the Idaho National Engineering Laboratory, Idaho. [Reference 6-5]}

Distribution coefficients can be used in models of ground-water flow to help predict the movement of chemical constituents in subsurface strata. Strontium distribution coefficients $\left(\mathrm{K}_{\mathrm{d}} \mathrm{s}\right)$ were measured for 20 surficial sediment samples collected from selected sites at the INEEL. The measurements were made to help assess the variability of strontium $\mathrm{K}_{\mathrm{d}} \mathrm{s}$ found at the INEEL as part of an ongoing investigation of strontium chemical transport properties of surficial and interbedded sediments at the INEEL. Batch experimental techniques were used to determine $\mathrm{K}_{d} \mathrm{~s}$ of surficial sediments using a synthesized aqueous solution representative of wastewater in waste disposal ponds at the INEEL. Strontium 
$\mathrm{K}_{\mathrm{d}} \mathrm{s}$ of the 20 surficial sediments ranged from $36+1$ to $275 \pm 6$ milliliters per gram, indicating significant variability in the strontium sorptive capacities of INEEL surficial sediments.

\section{Radiochemical and Chemical Constituents in Water from Selected Wells and Springs from the Southern Boundary of the Idaho National Engineering Laboratory to the Hagerman} Area, 1996. [Reference 6-6]

As part of the fourth round of a long-term project to monitor water quality of the Snake River Plain Aquifer from the INEEL southern boundary to the Hagerman area, the USGS and the Idaho Department of Water Resources sampled 19 sites during 1996. Water samples were collected and analyzed for selected radiochemical and chemical constituents. Samples were collected from nine irrigation wells, three domestic wells, two dairy wells, two springs, one commercial well, one stock well, and one observation well. Quality assurance samples were also collected and analyzed. Additional sampling was also done to complete the third round of sampling.

None of the radiochemical or chemical constituents exceeded the established maximum contaminant levels for drinking water.

Stratigraphy of the Unsaturated Zone and the Snake River Plain Aquifer at and near the Idaho Engineering Laboratory, Idaho. [Reference 6-7]

Historic liquid waste disposal at the INEEL has resulted in detectable concentrations of several waste constituents in the Snake River Plain Aquifer. Numerous studies of the subsurface at the INEEL have been performed due to public concern about the potential migration of radiochemical and chemical wastes in the unsaturated zone and aquifer. This document, following three earlier reports [Reference 6-8], describes a data base containing stratigraphic units in 333 wells that make up the unsaturated zone and the Snake River Plain Aquifer at and near the INEEL. A stratigraphic unit, as used in this document, is defined as the smallest layer of rock sequence that can be subdivided and correlated using the data available as of December 1993. Although the previous reports contain important geologic information, relationships among stratigraphic units and names identifying those units discussed in those reports are superseded by this document.

This report describes a variety of stratigraphic units including basalt-flow groups, sedimentary interbeds, andesite-flow groups, and one rhyolite dome. These units were identified and correlated using data from numerous outcrops, continuous cores, and natural-gamma logs. The main body of data in this document includes names, types, altitudes, depths, and thicknesses of the stratigraphic units.

\section{Chemical and Radiochemical Constituents in} Water from Wells in the Vicinity of the Naval Reactors Facility, Idaho National Engineering Laboratory, Idaho, 1994-1995.

[Reference 6-9]

The USGS sampled water from 14 wells during 1994-1995 as part of a long-term project to monitor water quality of the Snake River Plain aquifer near the Naval Reactors Facility, Idaho National Engineering and Environmental Laboratory, Idaho. A total of 111 samples were collected from 10 monitoring wells and production wells. Twelve quality assurance samples were also collected and analyzed: a blank sample and 11 replicate samples. Water samples were analyzed for naturally occurring constituents and manmade contaminants. Samples collected in 1994 were analyzed for chloride, chromium, iron, lead, mercury, nickel, nitrate as nitrogen, silver, sodium, sulfate, gross alpha and gross beta activity, $\mathrm{pH}$, specific conductance, and total organic carbon. In 1995 analyses were expanded to include aluminum, antimony, arsenic, barium, beryllium, cadmium, copper, manganese, selenium, thallium, tritium, and zinc. This report presents a compilation of the water chemistry data collected during 1994-1995, together with an analysis of quality assurance comparisons. 


\subsection{NON-RADIOLOGICAL MONITORING}

\section{USGS}

Sampling for purgeable (volatile) organic compounds in ground water was conducted by the USGS at the INEEL during 1997. Water samples from one onsite production well and 11 ground-water monitoring wells were collected and submitted to the USGS National Water Quality Laboratory in Arvada, Colorado, for analysis of 61 purgeable organic compounds. A USGS report describes the methods used to collect the water samples and ensure sampling and analytical quality [Reference 6-10].' Concentrations above the laboratory reporting level of $0.2 \mu \mathrm{g} / \mathrm{L}$ were detected for seven purgeable organic compounds: carbon tetrachloride, chloroform, tetrachloroethylene, 1,1,1-trichloroethane, trichloroethylene, dichloro-difluoro-methane, and total toluene (Table 6-1). The Radioactive Waste Management Complex (RWMC) production well contained detectable concentrations of purgeable organic compounds. Annual average concentrations of these compounds in this well increased slightly from those observed in 1995 and 1996. Carbon tetrachloride concentrations remained at levels near the MCL at the end of 1997 (Table 6-1).

\section{LMITCO}

The LMITCO Environmental Monitoring Unit routinely samples drinking water from wells and distribution systems at INEEL facilities for volatile organic compounds. At the TAN Technical Support Facility (TSF), the production wells and distribution systems are sampled more frequently since the discovery in 1987 that trichloroethylene concentrations in samples collected from TSF Well \#1 exceeded the EPA MCL. Concentrations in this well exceeded maximum contaminant levels for both samples collected in 1997 (Table 6-2).

Results from water samples at the wells and distribution system indicate that the aeration sys- tem is efficiently volatilizing trichloroethylene. Drinking water passes through the aeration system before reaching the distribution system. Since installation of the aeration system in 1988, drinking water samples from the TSF distribution system have generally not exceeded regulatory levels. During 1997, the TSF distribution system was in compliance.

Chlorinated drinking water systems are also monitored for total trihalomethanes (bromodichloromethane, bromoform, chloroform, and dibromochloromethane). The concentration of trihalomethanes in the Rifle Range distribution system remained significantly below the reporting level. The concentration in water from the CFA distribution system averaged about $7.1 \mu \mathrm{g} / \mathrm{L}$, or $7.1 \%$ of the EPA maximum contaminant level of $100 \mu \mathrm{g} / \mathrm{L}$.

From 1992 through 1995 the INEEL M\&O contractor which preceeded LMITCO conducted a semiannual monitoring program for lead and copper levels in drinking water in accordance with EPA regulations (40 CFR 141.80-141.91). Since regulatory values were not exceeded, this monitoring will be repeated in 1998 in accordance with regulations.

Water from the production and potable wells at INTEC and other facilities were sampled and analyzed once in 1997 for nitrogen as nitrate, lead, and silver (Table 6-3). None of these constituents were above the EPA maximum contaminant levels or state of Idaho drinking water limits in 1997.

Additional sampling was conducted in 1997 for a variety of inorganic constituents, including metals, nitrates, dissolved solids. There were no instances where the maximum contaminant levels were exceeded. More detailed information and data will be included in the 1997 LMITCO Environmental Monitoring Program Report for the Idaho National Engineering and Environmental Laboratory, INEEL/EXT-98-00305, due to be published in August 1998. 


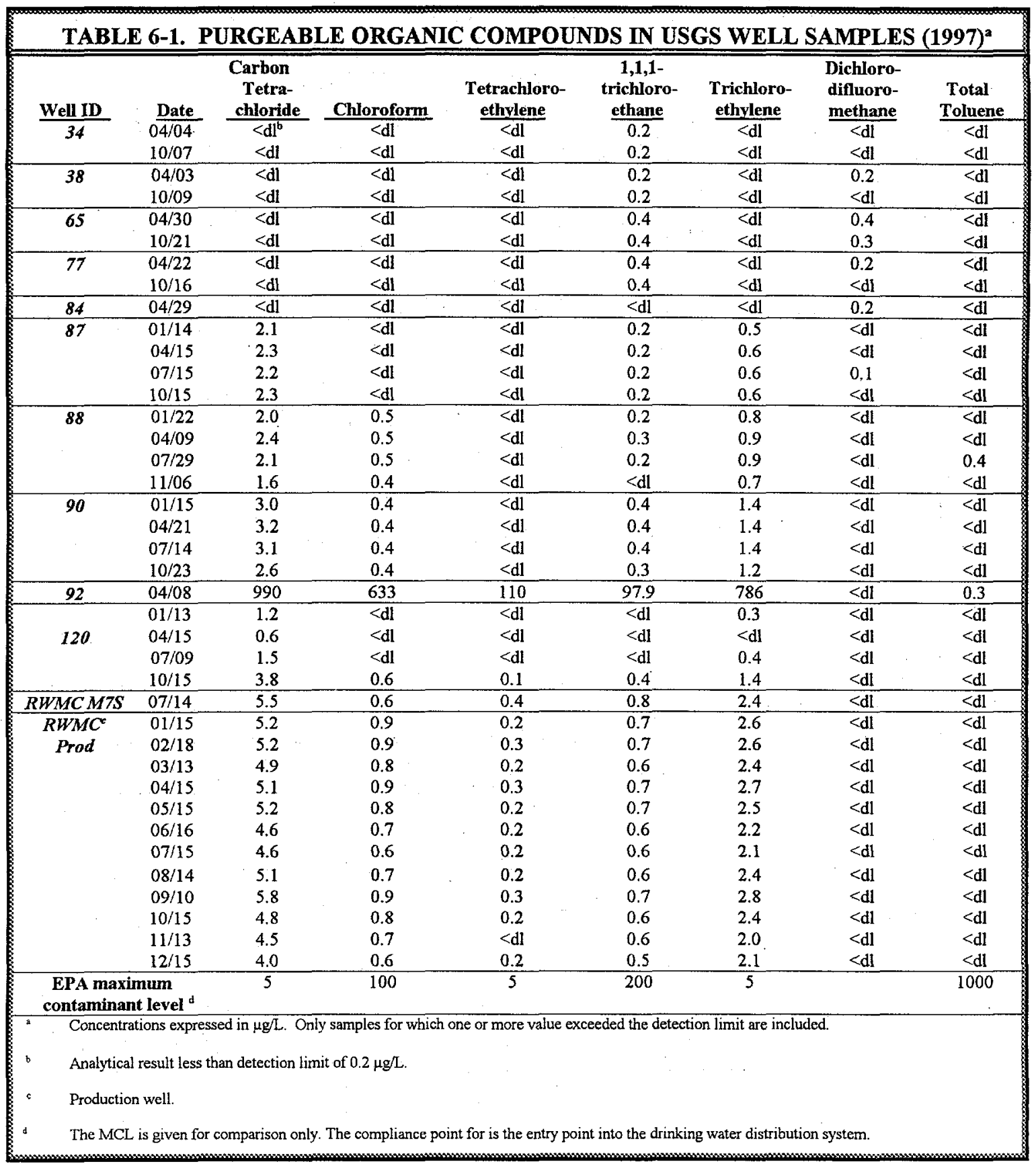

\section{Argonne National Laboratory - West (ANL-W)}

The Safe Drinking Water Act implementing regulations required monitoring only for nitrites, nitrates, and inorganic chemicals in ANL-W production wells during 1997. All parameters were well below applicable standards.

\section{Naval Reactors Facility (NRF)}

Drinking water samples were collected prior to entering the distribution system and monitored for volatile organic compounds, inorganic constituents, and water quality parameters. These 


\begin{tabular}{|c|c|c|c|c|c|c|c|c|c|c|c|c|}
\hline \multicolumn{13}{|c|}{$\begin{array}{l}\text { TABLE 6-2. PURGEABLE ORGANIC COMPOUNDS }[\mu \mathrm{g} / \mathrm{L}] \text { IN } \\
\text { INEEL DRINKING WATER }(1997)^{\mathrm{a}}\end{array}$} \\
\hline Well & Jan & $\underline{\text { Feb }}$ & $\underline{\text { Mar }}$ & Apr & May & Jun & $\underline{\text { Jul }}$ & $\underline{\text { Aug }}$ & Sep & Oct & $\underline{\text { Nov }}$ & $\underline{\text { Dec }}$ \\
\hline \multicolumn{13}{|c|}{ 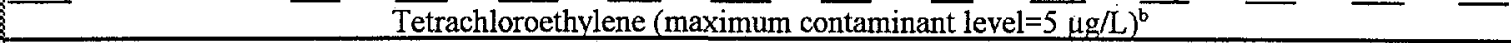 } \\
\hline RWMC Well & 0.2 & 0.2 & 0.3 & 0.3 & 0.3 & 0.2 & -- & 0.2 & 0.3 & 0.2 & 0.3 & 0.2 \\
\hline RWMC Dist. & - & --- & -- & 0.2 & 0.2 & -- & - & --- & -- & --- & -- & 0.2 \\
\hline TSF Dist. & 0.3 & 0.2 & -- & 0.3 & 0.3 & --- & -- & --- & -- & $\cdots$ & --- & -- \\
\hline TSF \#1 & 1.8 & -- & --- & --- & 1.6 & - & -- & -- & - & -- & --- & --- \\
\hline TSF \#2 & 1.1 & $\ldots$ & -- & -- & 0.6 & -- & $\because$ & $-\cdots$ & - & -- & -- & -- \\
\hline \multicolumn{13}{|c|}{ Trichloroethylene (maximum contaminant level $=5 \mu \mathrm{g} / \mathrm{L}$ ) } \\
\hline CFA Dist. & - & -- & -- & $-\cdots$ & 1.4 & $-\infty$ & - & -- & -- & --- & + & -- \\
\hline $\mathrm{CFA} \# 1$ & - & -- & -- & --- & 0.6 & --- & -- & - & - & --- & --- & $\cdots$ \\
\hline CFA\#2 & -- & --- & -- & -- & 1.5 & --- & - & - & -- & -- & -- & -- \\
\hline RWMC Well & 2.6 & 1.7 & 2.3 & 2.2 & 2.3 & 2.2 & 1.7 & 2.1 & 1.8 & 2.1 & 2.5 & 1.5 \\
\hline RWMC Dist. & 1.5 & 1.2 & 1.6 & 1.4 & 1.8 & 1.5 & 1.3 & 1.5 & 1.2 & 1.4 & 1.3 & 1.1 \\
\hline TSF Dist. & 1.0 & 0.7 & 0.6 & 0.5 & 1.3 & 1.3 & 0.1 & 0.9 & -- & -- & -- & -- \\
\hline TSF \#1 & 6.8 & -- & -- & - & 5.4 & --- & - & $\cdots$ & -- & --- & -- & -- \\
\hline TSF \#2 & 4.0 & -- & --- & - & 1.7 & --- & -- & -- & - & --- & -- & $-\cdots$ \\
\hline \multicolumn{13}{|c|}{ Total Trihalomethane (maximum contaminant level $=100 \mu \mathrm{g} / \mathrm{L}$ ) } \\
\hline CFA Dist. & 7.3 & -- & - & -- & 10.9 & $-\cdots$ & -- & 4.5 & $\cdots$ & -- & 5.5 & -- \\
\hline CPP Dist. & 0.2 & $\cdots$ & --- & --- & 2.7 & $-\cdots$ & -- & 18.9 & - & -- & 0.5 & --- \\
\hline CTF. Dist. & 1.7 & --- & -- & --- & 3.0 & -- & -- & 3.1 & -- & - & 2.6 & -- \\
\hline PBF Dist. & - & -- & -- & --- & -- & --- & --- & 7.8 & - & -- & 6.1 & -- \\
\hline TRA Dist. & 0.5 & -- & -- & --- & 0.4 & -- & -- & 4.2 & -- & - & 0.6 & --- \\
\hline TSF Dist. & 0.4 & -- & -- & --- & 2.3 & -- & - & 3.3 & - & - & -- & -- \\
\hline Rifle Range Dist. & $\leq 0.1$ & -- & --- & --- & $\leq 0.1$ & -- & -- & $\leq 0.1$ & $\ldots$ & - & $\leq 0.1$ & -- \\
\hline \multicolumn{13}{|c|}{ Ethylbenzene (maximum contaminant level $=700 \mu \mathrm{g} / \mathrm{L})^{\mathrm{b}}$} \\
\hline CFA Dist. & --- & $\cdots$ & $-\cdots$ & $\cdots$ & 0.2 & -- & -- & $\ldots$ & - & $\ldots$ & - & -- \\
\hline \multicolumn{13}{|c|}{ Total Xylenes (maximum contaminant level $=10,000 \mu \mathrm{g} / \mathrm{L}$ ) } \\
\hline CFA Dist. & --- & --- & - & --- & 1.6 & $\cdots$ & $\cdots$ & $\cdots$ & $-\cdots$ & -- & -- & -- \\
\hline CPP Dist. & -- & -- & -- & --- & 0.5 & -- & - & $\ldots$ & -- & -- & $\ldots$ & --- \\
\hline \multicolumn{13}{|c|}{ p-Dichlorobenzene (maximum contaminant level $=75 \mu \mathrm{g} / \mathrm{L}$ ) } \\
\hline EBR-1 Dist. & --- & --- & --- & $-\cdots$ & 2.1 & --- & -- & --- & -- & - & -- & --- \\
\hline Rifle Range Dist. & -- & --- & -- & --- & 0.7 & -- & -- & -- & $\rightarrow$ & -- & -- & -- \\
\hline RWMC Dist. & -- & --- & --- & $\ldots$ & -- & -- & 0.2 & --- & 0.3 & 0.1 & -- & 0.1 \\
\hline \multicolumn{13}{|c|}{ Carbon Tetrachloride (maximum contaminant level $=5 \mu \mathrm{g} / \mathrm{L}$ ) ${ }^{\mathrm{b}}$} \\
\hline $\mathrm{CFA \# 1}$ & $-\cdots$ & --- & $\bar{\cdots}$ & --- & 0.1 & -- & $-\cdots$ & $-\cdots$ & - & -- & $-\cdots$ & $-\cdots$ \\
\hline RWMC Well & 5.1 & 3.2 & 4.9 & 4.7 & 4.0 & 4.7 & 4.1 & 4.1 & 3.8 & 4.8 & 4.4 & 2.9 \\
\hline RWMC Dist. & 2.4 & 2.2 & 3.0 & 2.6 & 3.1 & 2.8 & 2.6 & 2.9 & 2.4 & 2.8 & 2.6 & 2.5 \\
\hline \multicolumn{13}{|c|}{$1,1,1$-Trichloroethane (maximum contaminant level $=200 \mu \mathrm{g} / \mathrm{L}$ ) ${ }^{\mathrm{b}}$} \\
\hline CFA \#1 & --- & --- & --- & --- & 0.4 & -- & $-\cdots$ & --- & - & --- & -- & -- \\
\hline $\mathrm{CFA} \mathrm{\# 2}$ & $\cdots$ & --- & $-\cdots$ & -- & 0.3 & -- & --- & -- & - & --- & --- & - \\
\hline CFA Dist. & -- & --- & $\cdots$ & --- & 0.3 & -- & --- & -- & -- & $-\cdots$ & --- & - \\
\hline CTF Dist. & -- & --- & --- & -- & 0.1 & -- & -- & -- & - & --- & -- & -- \\
\hline Main Gate Dist. & - & -- & -- & --- & 1.2 & -- & --- & --- & - & --- & --- & --- \\
\hline Rifle Range Dist. & -- & -- & --- & - & 0.2 & --- & --- & --- & -- & --- & $-\cdots$ & --- \\
\hline RWMC Well & 0.7 & 0.4 & 0.6 & 0.6 & 0.6 & 0.6 & 0.5 & 0.5 & 0.5 & 0.6 & 0.4 & 0.2 \\
\hline RWMC Dist. & 0.3 & 0.2 & 0.4 & 0.3 & 0.4 & 0.4 & 0.3 & 0.4 & 0.3 & 0.3 & 0.3 & 0.3 \\
\hline
\end{tabular}




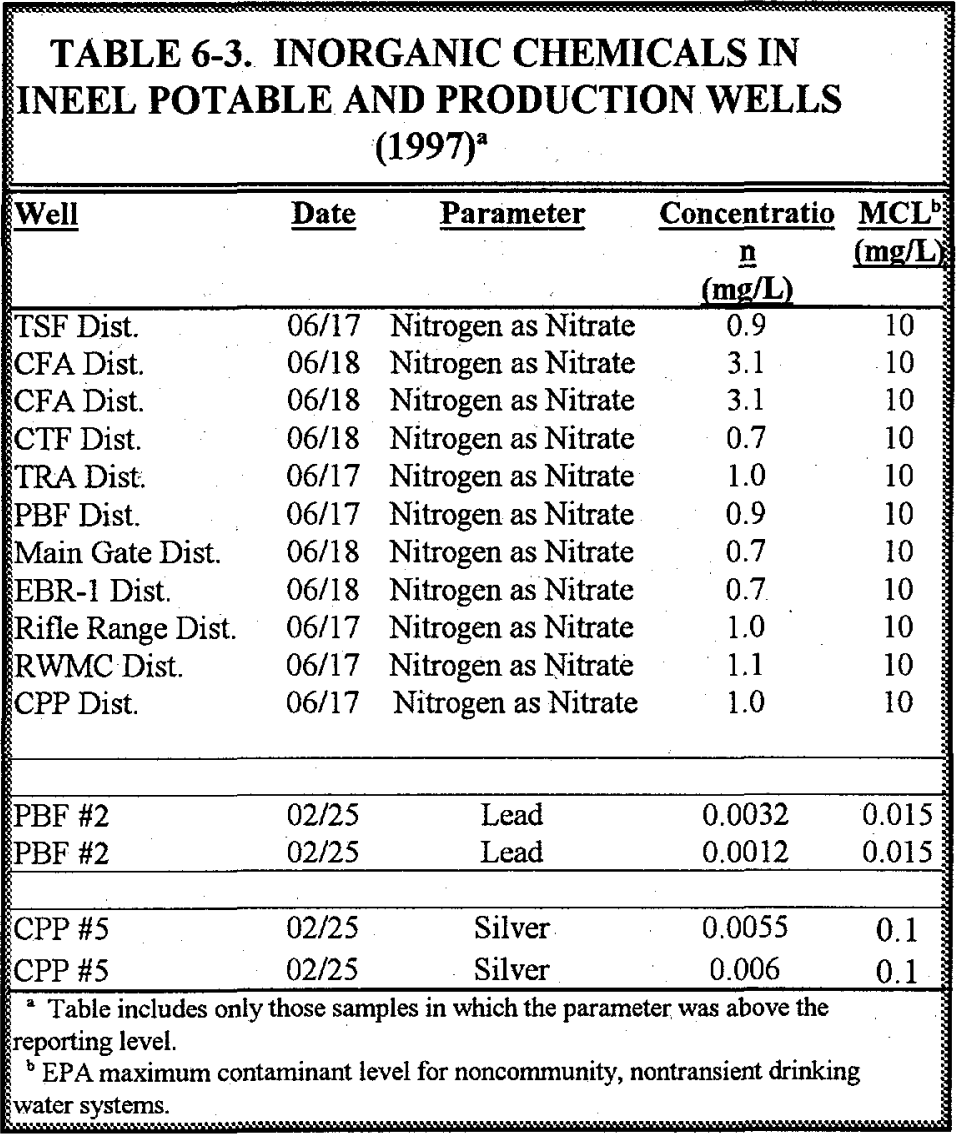

\subsection{RADIOCHEMICAL MONITORING}

\section{USGS: Contaminant Plumes}

Historic waste disposal practices have produced localized plumes of radiochemical and chemical contaminants in the Snake River Plain Aquifer at the INEEL. Of principal concern over the years have been the movements of the tritium and ${ }^{90} \mathrm{Sr}$ plumes.

The tritium plume has developed from the disposal of wastewater at the INEEL since the 1950s. About $31,750 \mathrm{Ci}$ of tritium have been discharged to wells and ponds since 1952. The main sources of tritium contamination of ground water have been the injection of wastewater through the INTEC disposal well and the discharge of wastewater to the infiltration ponds at the INTEC and TRA. Since 1984, wastewater has been discharged only to the infiltration ponds, and since 1993 principally to

samples were drawn from a sampling port immediately downstream from the NRF water softening treatment system. No volatile organic compounds were detected above minimum detection levels established for the analyses of these compounds. Concentrations of inorganic analytes and water quality parameters were all below regulatory limits.

Lead and copper monitoring of the NRF drinking water system continued in 1997 in accordance with applicable state and federal regulations. Concentrations of lead and copper at NRF were below regulatory action levels.

With the assistance of USGS, ground-water monitoring continued around NRF (Figure 6-3). Specifics regarding this monitoring are published in the NRF Environmental Monitoring Report for Calendar Year 1997. lined evaporation ponds.

The configuration and extent of the tritium plume, based on the latest data, are shown in Figure 6-4 [Reference 6-1]. The area of the plume within the $0.5 \mathrm{pCi} / \mathrm{mL}$ contour line decreased from about $115 \mathrm{~km}^{2}\left(45 \mathrm{mi}^{2}\right)$ in 1988 to about $102 \mathrm{~km}^{2}\left(40 \mathrm{mi}^{2}\right)$ in 1991 [Reference 611]. In 1995, the area was about the same as it was in 1991. Concentrations of tritium in the plume have generally decreased. The area of elevated concentrations near CFA may represent water originating at INTEC some years earlier when larger amounts of tritium were disposed, since there is no source of tritium contamination of ground water at CFA. Tritium concentrations in quarterly samples taken by LMITCO in 1997 at wells at CFA are given in Table 6-4 


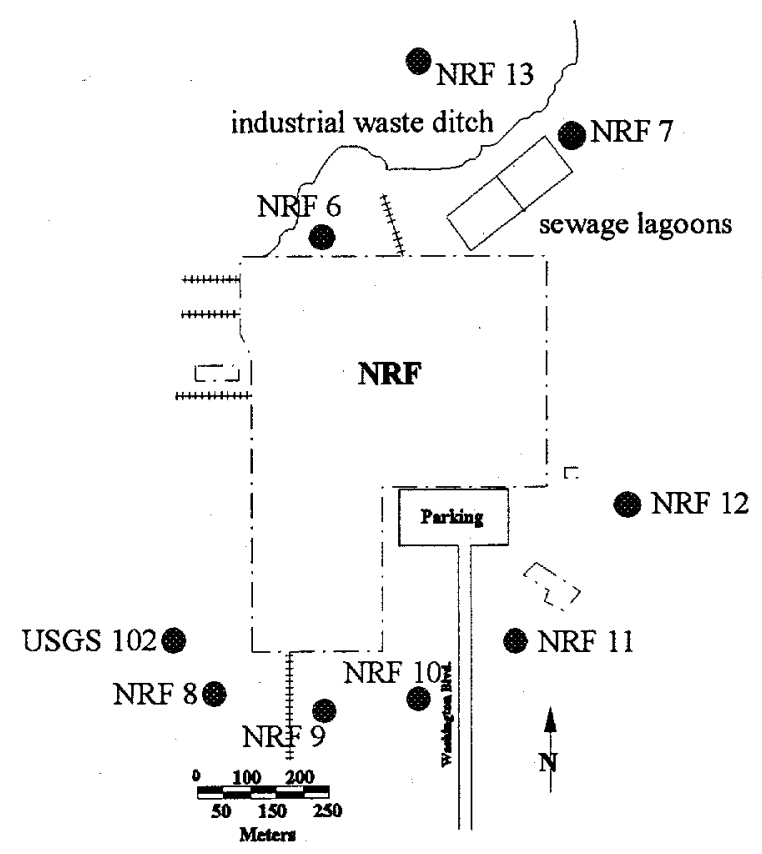

Figure 6-3. Monitoring wells around NRF.

The tritium concentration in well 65 near TRA (Figure 6-2) decreased from $37.8 \pm 0.8$ $\mathrm{pCi} / \mathrm{mL}$ in 1991 to $21.2 \pm 0.9 \mathrm{pCi} / \mathrm{mL}$ in 1995 ; the tritium concentration in well 77 south of INTEC (Figure 6-2) decreased from $41.7 \pm 0.9$ $\mathrm{pCi} / \mathrm{mL}$ in 1991 to $25.1 \pm 1.0$ in 1995 . The EPA maximum contaminant level (MCL) for tritium is $20 \mathrm{pCi} / \mathrm{mL}$. These decreased tritium concentrations over the long term are primarily due to radioactive decay (tritium has a half-life of 12.3 years) and a decrease in tritium disposal rates. The average combined rate of tritium disposal at the TRA and INTEC during 1952-83 was 910 $\mathrm{Ci} / \mathrm{yr}$; during 1984-91, $280 \mathrm{Ci} / \mathrm{yr}$; and during $1992-95,107 \mathrm{Ci} / \mathrm{yr}$

During 1952-95, the INEEL disposed of about $93 \mathrm{Ci}$ of ${ }^{90} \mathrm{Sr}$ at TRA and about $57 \mathrm{Ci}$ at INTEC. However, only at INTEC was an injection well used for disposal of some of the ${ }^{90} \mathrm{Sr}$ directly to the aquifer. This practice was discontinued in the 1980s. During 1992-95, the INEEL disposed of about $0.1 \mathrm{Ci}$ of ${ }^{90} \mathrm{Sr}$ to the TRA infiltration ponds. These ponds were replaced by hypalon plastic-lined evaporation ponds in August 1993.
The configuration and extent of the ${ }^{90} \mathrm{Sr}$ contaminant plume, based on the latest data, are shown in Figure 6-5 [Reference 6-1]. The plume originates from the INTEC. No ${ }^{90} \mathrm{Sr}$ contaminant plume has been detected in the vicinity of TRA. At TRA, ${ }^{90} \mathrm{Sr}$ probably is retained in surficial sedimentary deposits and in interbeds, but is not intercepted by perched ground water zones. All ${ }^{90} \mathrm{Sr}$ at TRA was disposed to infiltration ponds in contrast to the direct injection which occurred at the INTEC. The area of the ${ }^{90} \mathrm{Sr}$ contaminant plume is approximately the same as it was in 1991. Concentrations of ${ }^{90} \mathrm{Sr}$ in the wells have remained relatively constant since 1991. The concentrations during 1992-95 ranged from $2.6 \pm 0.7 \mathrm{pCi} / \mathrm{L}$ to $76 \pm 3 \mathrm{pCi} / \mathrm{L}$. The MCL for ${ }^{90} \mathrm{Sr}$ in drinking water is $8 \mathrm{pCi} / \mathrm{L}$.

Prior to $1989,{ }^{90} \mathrm{Sr}$ concentrations had been decreasing because of changes in waste disposal practices and radioactive decay, diffusion, dispersion, and dilution from natural ground-water recharge [Reference 6-12]. The relatively constant ${ }^{90} \mathrm{Sr}$ concentrations in the wells sampled from 1992 to 1995 is thought due, in part, to a lack of recharge from the Big Lost River that would act to dilute the ${ }^{90} \mathrm{Sr}$. Also, an increase in the disposal of other chemicals into the INTEC infiltration ponds may have affected the adsorption, via ion-exchange, of ${ }^{90} \mathrm{Sr}$ to soil and rock surfaces, allowing more ${ }^{90} \mathrm{Sr}$ to exist in the liquid phase [Reference 6-1].

\section{LMITCO}

Gross Alpha. Of the 60 onsite production well and distribution system samples analyzed for gross alpha in 1997, a total of 22 samples contained activities above the minimum detectable concentration. The highest concentration was in a sample from the TAN/CTF Distribution System at $(7 \pm 2) \times 10^{-9} \mu \mathrm{Ci} / \mathrm{mL}$. This value is $45 \%$ of the EPA MCL of $15 \times 10^{-9} \mu \mathrm{Ci} / \mathrm{mL}$ for gross alpha in drinking water.

All gross alpha activities were within the expected concentration range for naturally occurring alpha activity in the aquifer underlying the 


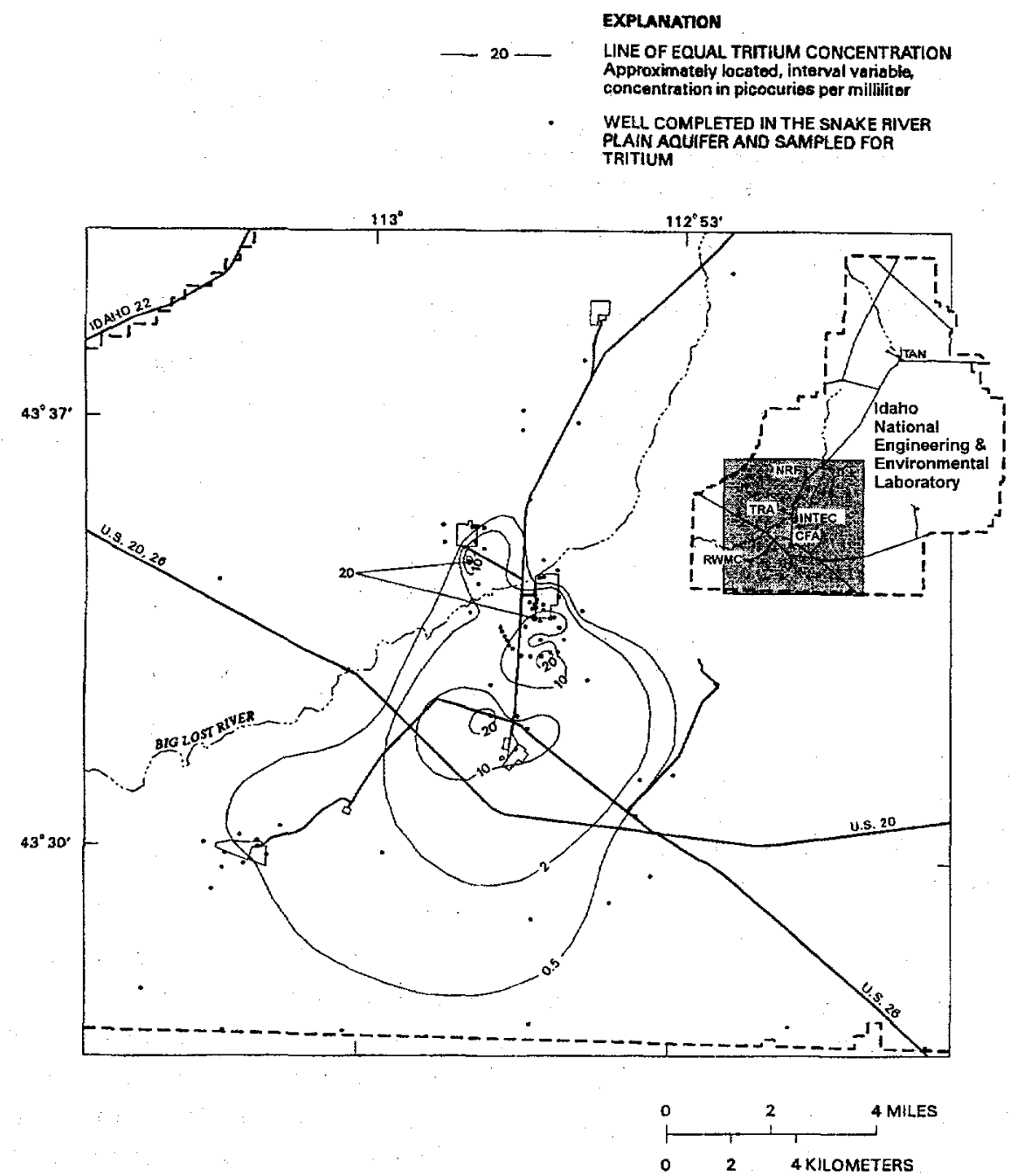

Figure 6-4. Distribution of tritium in the Snake River Plain Aquifer on the INEEL, 1995

Snake River Plain, including the INEEL. According to USGS reports, alpha-emitting wastes $\left({ }^{238} \mathrm{Pu},{ }^{239 / 240} \mathrm{Pu}\right.$, and $\left.{ }^{241} \mathrm{Am}\right)$ from INEEL operations have not migrated far from their entrance into the aquifer near INTEC [References 6-1, 6-11, 6-12, and 6-13]. All onsite drinking water wells lie outside the migration plumes for alpha-emitting nuclides.

Gross Beta. Of the 60 onsite production well samples analyzed for gross beta, 50 had gross beta activities above the minimum detectable concentration. All were within the range typically found for background concentrations from natural radioactivity in the Snake River Plain
Aquifer. The highest observed activity was $(7 \pm 3) \times 10^{-9} \mu \mathrm{Ci} / \mathrm{mL}$ in a sample from the CFA distribution system in February. This value is $14 \%$ of the EPA MCL of $50 \times 10^{-9}$ $\mu \mathrm{Ci} / \mathrm{mL}$ for gross beta in drinking water.

Tritium. Water from three of the onsite production wells and three drinking water distribution systems that were routinely sampled showed detectable concentrations of tritium in each sample (Table 6-4). Figure 6-6 shows 10 years of tritium data for two of the production wells and two distribution systems. Two of five samples from the INTEC distribution system contained detectable tritium concentrations. The highest concentration of the two INTEC samples was $0.2 \pm 0.1 \times 10^{-6} \mu \mathrm{Ci} / \mathrm{mL}$. No other onsite drinking water samples contained detectable tritium concentrations.

Strontium-90. Because of the presence of the localized plume of ${ }^{90} \mathrm{Sr}$ in the ground water near INTEC, sampling from several production wells at INTEC is routinely performed. While samples have historically contained detectable levels of ${ }^{90} \mathrm{Sr}$, none of the 1997 samples exhibited detectable concentrations of ${ }^{90} \mathrm{Sr}$ (the minimum detectable concentration was approximately $\left.2 \times 10^{-9} \mu \mathrm{Ci} / \mathrm{mL}\right)$.

CFA Worker Dose. The potential effective dose equivalent to a worker at CFA from radioactivity in water was calculated. CFA was selected 


\begin{tabular}{|c|c|c|c|c|c|}
\hline TABLE 6 & \multicolumn{5}{|c|}{ WELLS AND DISTRIBUTION SYSTEMS (1997) } \\
\hline \multirow[b]{2}{*}{ Well Code } & \multirow{2}{*}{$\begin{array}{c}\text { \# of } \\
\text { Samples }\end{array}$} & \multicolumn{3}{|c|}{$\begin{array}{c}\text { Tritium Concentration } \\
\left(\times 10^{-6} \mu \mathrm{Ci} / \mathrm{mL}\right)^{\mathrm{a}}\end{array}$} & \multirow[b]{2}{*}{$\% \mathrm{MCL}^{\mathrm{e}}$} \\
\hline & & Minimum $^{c}$ & $\underline{\text { Maximum }}^{c}$ & Mean $^{\mathrm{d}}$ & \\
\hline CFA Dist. & 5 & $9.7 \pm 0.7$ & $\overline{16.5 \pm 1.1}$ & $13.3 \pm 2.2$ & 67 \\
\hline CFA \# 1 & 4 & $11.7 \pm 0.8$ & $15.9 \pm 1.1$ & $13.4 \pm 1.7$ & 67 \\
\hline CFA \#2 & 3 & $10.9 \pm 0.7$ & $12.4 \pm 0.9$ & $11.9 \pm 0.9$ & 60 \\
\hline Rifle Range & 4 & $2.9 \pm 0.2$ & $3.3 \pm 0.3$ & $3.1 \pm 0.2$ & 16 \\
\hline RWMC Dist. & 4 & $1.5 \pm 0.2$ & $1.6 \pm 0.2$ & $1.6 \pm 0.1$ & 8 \\
\hline RWMC Well & 4 & $1.5 \pm 0.2$ & $2.8 \pm 0.2$ & $1.8 \pm 0.6$ & 9 \\
\hline INTEC Dist. & 5 & $0.01 \pm 0.1$ & $0.2 \pm 0.1$ & $0.1 \pm 0.1$ & 0.5 \\
\hline TAN/CTF Dist. & 3 & $-0.1 \pm 0.1$ & $0.2 \pm 0.1$ & $0.1 \pm 0.2$ & 1 \\
\hline TAN/TSF & 3 & $-0.1 \pm 0.1$ & $0.1 \pm 0.1$ & $0.02 \pm 0.1$ & 0.1 \\
\hline TRA Dist. & 5 & $-0.1 \pm 0.1$ & $0.1 \pm 0.1$ & $0.002 \pm 0.1$ & 0.001 \\
\hline $\begin{array}{ll}\text { Equivalent to } \mathrm{pC} \\
\quad \text { Samples taken o } \\
\text { Tritium concent }\end{array}$ & $\begin{array}{l}\mathrm{mL} \\
\text { ly from wel } \\
\text { tion } \pm 2 \mathrm{~s}\end{array}$ & llection time & & & \\
\hline $\begin{array}{l}\text { Arithmetic mear } \\
\text { EPA drinking w }\end{array}$ & 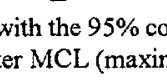 & tan & s 20 & & \\
\hline
\end{tabular}

because tritium concentrations found in these wells were the highest of any drinking water wells. The 1997 calculation was based on:

- Mean tritium concentration for the CFA distribution system in 1997 as shown in Table 6-4.

- Data from a 1990-91 USGS study for ${ }^{129} \mathrm{I}$ using the accelerator mass spectrographic analytical technique that indicated water from CFA \#1 contained ${ }^{129} I$ at a concentration of $(0.26 \pm 0.05) \times 10^{-9} \mu \mathrm{Ci} / \mathrm{mL}$ (the average of two samples) and water from CFA \#2 had a concentration of $(0.14 \pm 0.03) \times 10^{-9} \mu \mathrm{Ci} / \mathrm{mL}$ (also the average of two samples). For perspective, the proposed EPA drinking water standard for ${ }^{129} \mathrm{I}$ in drinking water is $21 \times 10^{-9}$ $\mu \mathrm{Ci} / \mathrm{mL}$

- Water usage information for 1997 showing CFA \#1 was used for approximately $37 \%$ of the drinking water and CFA \#2 was used for $63 \%$ of the drinking water.
For the 1997 dose calculation, the assumption was made that each worker's total water intake came from the CFA drinking water distribution system. This assumption over-estimates the dose because workers typically consume only about half their total intake during working hours and typically work only 240 days rather than 365 days per year. The estimated effective dose equivalent to a worker from consuming all drinking water at CFA during 1997 was $0.6 \mathrm{mrem}, 15 \%$ of the EPA standard of $4 \mathrm{mrem}$ for community drinking water systems.

\section{ANL-W}

During 1997, ANL-W analyzed four quarterly samples for gross alpha, gross beta, and tritium from the entrance to the distribution system in accordance with state of Idaho guidance. The maximum gross alpha concentration was $2 \pm 1$ $\mathrm{pCi} / \mathrm{L}$ ( $13 \%$ of the maximum contaminant level); the maximum gross beta concentration was $4 \pm 1$ $\mathrm{pCi} / \mathrm{L}$ ( $8 \%$ of the maximum contaminant level). No samples contained detectable concentrations of tritium. 


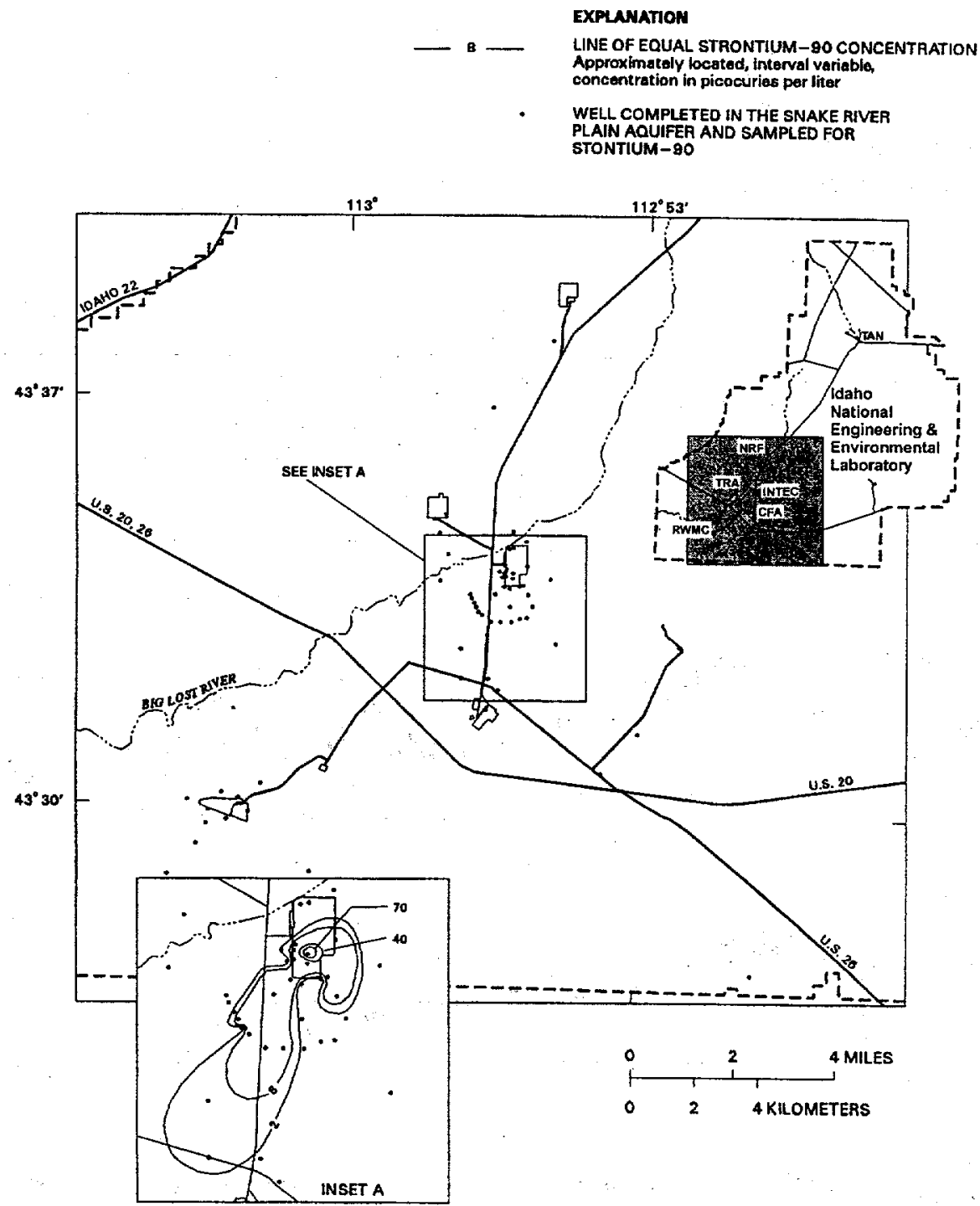

NRF

Ground-water monitoring from NRF ground-water wells did not detect any gross alpha or gross beta activity in excess of natural background concentrations.

\section{4 \\ BACTERIOLOGICAL MONITORING}

\section{LMITCO}

Potable water at the INEEL was monitored for coliform bacteria quarterly or monthly by contractor personnel and analyzed by the LMITCO Environmental Hygiene Laboratory. A total of 496 samples were collected at 12 INEEL facilities during 1997. All of these samples tested negatively for the presence of coliform bacteria.

Figure 6-5. Distribution of ${ }^{90} \mathrm{Sr}$ in the Snake River Plain Aquifer on the INEEL, 1995

ANL-W sampled its Industrial Waste Pond and Secondary Sanitary Lagoon monthly. The water samples were analyzed for gross alpha, gross beta, tritium, and gamma-emitting radionuclides. No gross alpha, tritium, or gammaemitting radionuclides were detected in either pond. Gross beta activity was regularly detected in the Secondary Sanitary Lagoon with values ranging from $36 \times 10^{-9}$ to $58 \times 10^{-9} \mu \mathrm{Ci} / \mathrm{mL}$. No gross alpha activity was detected in the Industrial Waste Pond.

\section{NRF}

Drinking water samples were collected monthly and analyzed for the presence of coliform bacteria. Frequency and sample locations met the requirements of applicable state and federal regulations. No coliform bacteria were detected in the NRF drinking water supply system. 


\section{ANL-W}

ANL-W conducted monthly bacteriological sampling, with analysis performed by the LMITCO Environmental Hygiene Laboratory. No detections were found in 1997

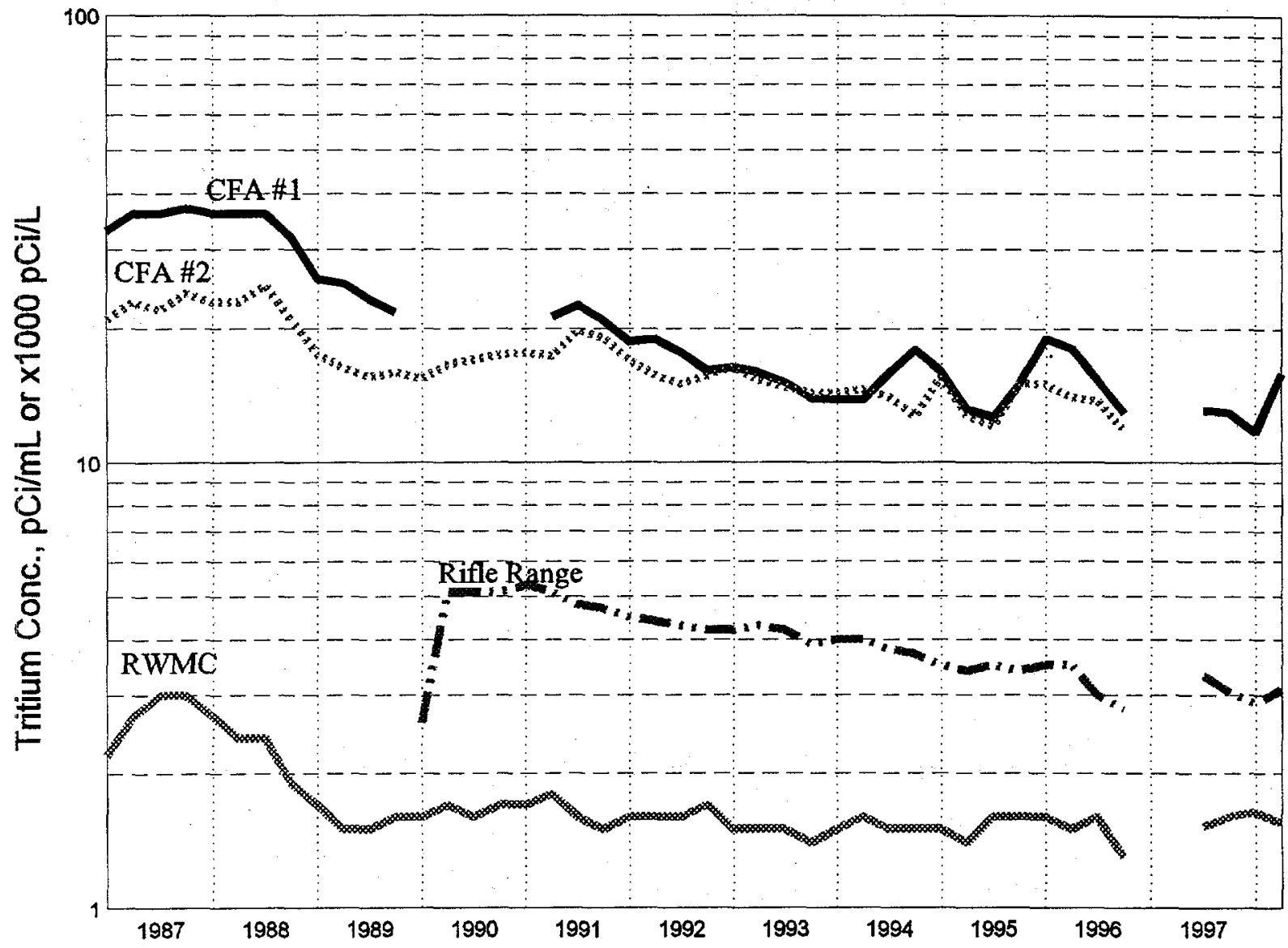

Figure 6.6. Tritium Concentrations in INEEL Production Wells and Distribution Systems (1987-1997) 


\section{Summary of Chapter 7 Effluent Monitoring}

Certain facility operations at the Idaho National Engineering and Environmental Laboratory (INEEL) have the potential to release airborne and liquid radioactive effluents (Section 7.1). The quantity of airborne radioactive effluents released during calendar year 1997 increased substantially over the totals released during the previous three years, due primarily to operations at Argonne National Laboratories-West (ANL- W). The radionuclides comprising the vast majority of radioactive airborne releases for 1997 are discussed, and year to year comparisons are provided. The quantity of liquid radioactive effluents released during 1997 increased slightly over the amount released during 1996.

Section 7.2 summarizes the nonradioactive airborne and liquid effluents released during 1997 from INEEL facilities. Airborne releases increased in 1997 due to the operation of the New Waste Calcining Facility (NWCF) at the Idaho Nuclear Technology and Engineering Center (INTEC). This facility operated approximately six months during 1997 after being idle since October, 1993. Tables summarizing effluent components, amounts released, and year to year comparisons accompany discussion of effluent monitoring by each INEEL facility of concern. 



\section{EFFLUENT MONITORING}

\subsection{RADIOACTIVE EFFLUENTS}

\section{General}

In compliance with state and federal regulations, radionuclides released to the environment during 1997 via airborne and liquid effluents were monitored at potentially significant release sites. These sites included stacks and liquid effluent streams, monitored by INEEL contractors at the relevant facilities. Monitoring results were reported to the Radioactive Waste Management Information System (RWMIS) administered by Lockheed Martin Idaho Technologies Company (LMITCO). Effluent information from the RWMIS is used to produce annual reports summarizing effluent monitoring by month, facility and radionuclide.

\section{Airborne}

During 1997, an estimated 5,595 Curies (Ci) of radioactivity were released to the atmosphere from all INEEL sources [Reference 7-1]. Ninety-five percent of the total airborne radioactivity effluent was released from two INEEL facilities, the Test Reactor Area (TRA) and Argonne National Laboratory-West (ANL-W). These and other totals are displayed in Table 7-1. The TRA released $1,695 \mathrm{Ci}$, of which over $93 \%$ was from radioisotopes of noble gases. ANL-W released $3,605 \mathrm{Ci}$, of which radioisotopes of noble gases comprised over $99 \%$ of the total. Noble gases are the elements from Group 8 on the periodic table of the elements, and by their stable nature, are generally not reactive. The primary exposure concern is external, as noble gases are generally not transported through food chains or concentrate in biological tissues [Reference 7-2].

Year-to-year fluctuations in airborne radioactive effluent releases are dependant on which processes are active at INEEL facilities. The total for 1997 is considerably higher than the annual totals for 1993-1996 (Figure 7-1), due primarily to the $3,579 \mathrm{Ci}$ of ${ }^{85} \mathrm{Kr}$ released from ANL-W. Krypton-85, a noble gas, was released from ANL-W as part of a spent fuel treatment project titled the Electrometallurgical Treatment Research and Demonstration Project in the Fuel Conditioning Facility. Although airborne releases during 1997 are the highest of the past five years, they are still considerably less than the annual totals for the 1980 's.

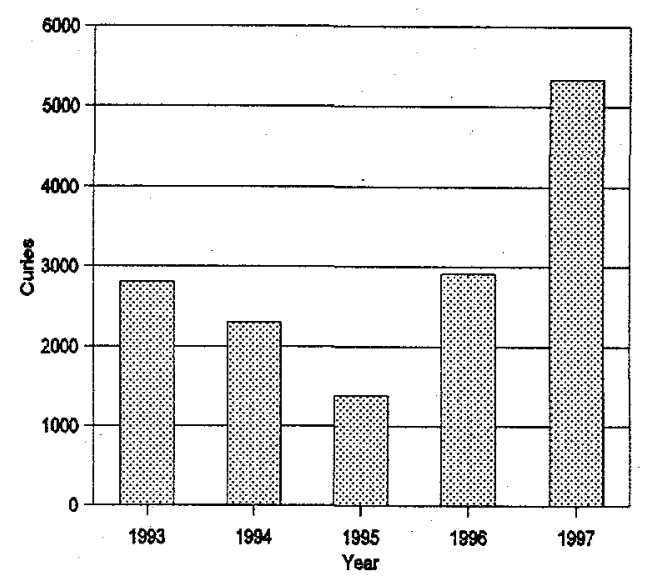

Figure 7-1. INEEL Airborne Radioactive Effluent

\section{Liquid}

Table 7-2 summarizes the radioactive liquid effluents released onsite during 1997 . Virtually all of the 1997 radioactive liquid effluent was released from TRA into two hypalon plastic-lined evaporation ponds which have been in use since August 1993. These ponds serve to prevent contaminant percolation into the ground, thus minimizing contaminant dispersal. No radioactive liquid effluent was released to the offsite environment from INEEL facilities during 1997. Routine injections of radioactive liquid effluents into the Snake River Plain Aquifer ceased in 1984. 


\begin{tabular}{|c|c|c|c|c|c|c|c|c|c|}
\hline \multirow{2}{*}{$\begin{array}{c}\text { Effluent } \\
\text { Type }\end{array}$} & \multirow{2}{*}{$\begin{array}{l}\text { Radio- } \\
\text { nuclide }\end{array}$} & \multirow[b]{2}{*}{ Balf-life } & \multicolumn{7}{|c|}{ Airborne Effluent (Ci) ${ }^{a}$} \\
\hline & & & ANL-W & CFA & INTEC & NRF & RWMC & TRA & Total $^{b}$ \\
\hline \multirow[t]{9}{*}{ Noble Gases } & ${ }^{41} \mathrm{Ar}$ & $1.83 \mathrm{~h}$ & 3.9 & -- & - & -- & -- & 1,550 & 1,554 \\
\hline & 要 $\mathrm{Kr}$ & $10.7 \mathrm{yr}$ & 3,579 & -- & -- & -- & - & - & 3,579 \\
\hline & ${ }^{135} \mathrm{Xe}$ & $9.10 \mathrm{~h}$ & -- & -- & -- & -- & -- & 20.9 & 20.9 \\
\hline & ${ }^{88} \mathrm{Kr}$ & $2.84 \mathrm{~h}$ & -- & -- & -- & -- & -- & 3.5 & 3.5 \\
\hline & ${ }^{85 \mathrm{~m}} \mathrm{Kr}$ & $4.48 \mathrm{~h}$ & -- & -- & -- & -- & -- & 3.0 & 3.0 \\
\hline & ${ }^{133} \mathrm{Xe}$ & $5.25 \mathrm{~d}$ & -- & -- & -- & - & -- & 3.4 & 3.4 \\
\hline & ${ }^{87} \mathrm{Kr}$ & $1.27 \mathrm{~h}$ & -- & -- & -- & -- & -- & 1.8 & 1.8 \\
\hline & ${ }^{138} \mathrm{Xe}$ & $14.2 \mathrm{~min}$ & -- & -. & -- & -- & -- & 0.8 & 0.8 \\
\hline & ${ }^{135 \mathrm{~m}} \mathrm{Xe}$ & $15.3 \mathrm{~min}$ & -- & -- & -- & -- & -- & 1.1 & 1.1 \\
\hline \multirow[t]{11}{*}{ Particulates } & ${ }^{88} \mathrm{Rb}$ & $17.7 \mathrm{~min}$ & -- & -- & -- & -- & -- & 1.3 & 1.3 \\
\hline & ${ }^{89} \mathrm{Rb}$ & $15.4 \mathrm{~min}$ & -- & -- & -- & - & -- & $1.1 \times 10^{-2}$ & $1.1 \times 10^{-2}$ \\
\hline & ${ }^{138} \mathrm{Cs}$ & $32.2 \mathrm{~min}$ & -- & -- & - & -- & -- & $6.9 \times 10^{-2}$ & $6.9 \times 10^{-2}$ \\
\hline & ${ }^{51} \mathrm{Cr}$ & $27.8 \mathrm{~d}$ & -- & -- & -- & -- & -- & $5.6 \times 10^{-3}$ & $5.6 \times 10^{-3}$ \\
\hline & ${ }^{24} \mathrm{Na}$ & $15.6 \mathrm{~h}$ & - & -- & -- & -- & - & $1.4 \times 10^{-2}$ & $1.4 \times 10^{-2}$ \\
\hline & ${ }^{137} \mathrm{Cs}$ & $30.2 \mathrm{yr}$ & -- & $1.6 \times 10^{-5}$ & $6.8 \times 10^{-3}$ & $3.6 \times 10^{-5}$ & $1.4 \times 10^{-5}$ & $3.3 \times 10^{-5}$ & $7.1 \times 10^{-3}$ \\
\hline & ${ }^{99 \mathrm{~m}} \mathrm{Tc}$ & $6.01 \mathrm{~h}$ & -- & -- & -- & -- & -- & $2.2 \times 10^{-3}$ & $2.2 \times 10^{-3}$ \\
\hline & ${ }^{125} \mathrm{Sb}$ & $2.73 \mathrm{yr}$ & -- & - & $2.4 \times 10^{-5}$ & -- & -- & $2.6 \times 10^{-6}$ & $2.7 \times 10^{-5}$ \\
\hline & ${ }^{90} \mathrm{Sr}+\mathrm{D}^{\mathrm{c}}$ & $28.6 \mathrm{yr}$ & -- & -- & $6.9 \times 10^{-4}$ & -- & -- & $1.2 \times 10^{-6}$ & $7.0 \times 10^{-4}$ \\
\hline & ${ }^{238} \mathrm{Pu}$ & $87.7 \mathrm{yr}$ & -- & -- & $5.1 \times 10^{-6}$ & -. & - & -- & $5.1 \times 10^{-6}$ \\
\hline & ${ }^{239} \mathrm{Pu}$ & $2.4 \times 10^{4} \mathrm{yr}$ & $1.1 \times 10^{-7}$ & -- & $9.8 \times 10^{-7}$ & - & -- & $5.2 \times 10^{-7}$ & $1.6 \times 10^{-6}$ \\
\hline \multirow{5}{*}{$\begin{array}{l}\text { Tritium, }{ }^{14} \mathrm{C} \\
\text { and Iodine } \\
\text { Isotopes }\end{array}$} & ${ }^{3} \mathrm{H}$ & $12.3 \mathrm{yr}$ & 23.0 & 2.2 & 132 & $7.8 \times 10^{-2}$ & 160 & 109 & 426 \\
\hline & ${ }^{14} \mathrm{C}$ & $5,700 \mathrm{yr}$ & -- & -- & -- & 0.81 & $8.2 \times 10^{-2}$ & -- & 0.91 \\
\hline & ${ }^{129} \mathrm{I}$ & $1.6 \times 10^{7} \mathrm{yr}$ & -- & -- & $5.8 \times 10^{-2}$ & -- & -- & - & $5.8 \times 10^{-2}$ \\
\hline & ${ }^{131} \mathbf{I}$ & $8.04 \mathrm{~d}$ & -- & -- & -- & $1.7 \times 10^{-5}$ & -- & $1.7 \times 10^{-3}$ & $1.7 \times 10^{-3}$ \\
\hline & ${ }^{133} \mathrm{I}$ & $20.8 \mathrm{~h}$ & -- & -- & -- & - & -- & $5.5 \times 10^{-4}$ & $5.5 \times 10^{-4}$ \\
\hline \multicolumn{2}{|l|}{ All others } & - & $3.9 \times 10^{-5}$ & $3.6 \times 10^{-6}$ & $1.0 \times 10^{-4}$ & $1.0 \times 10^{-4}$ & $2.9 \times 10^{-2}$ & $3.3 \times 10^{-3}$ & $3.5 \times 10^{-3}$ \\
\hline \multicolumn{2}{|l|}{ Totals } & -- & 3,605 & 2.2 & 132 & 0.9 & 160 & 1695 & 5,595 \\
\hline \multicolumn{10}{|c|}{$\begin{array}{l}\text { Radioactive release information provided by the report } 1997 \text { INEEL National Emissions Standard for Hazardous Air Pollutants }- \text { Radionuclides, } \\
\text { DOE/IDD } 10342(97) \text {, June } 1998 \text {. The table includes all radionuclides with total releases greater than } 1 \times 10^{-3} \mathrm{Ci}\left(1 \times 10^{-4} \text { for isotopes of iodine). Some }\right. \\
\text { radjonuclides of special concern }\left({ }^{125} \mathrm{Sb},{ }^{9} \mathrm{Sr},{ }^{137} \mathrm{Cs} \text {, and Pu) are also included. Values are not corrected for decay after release. }\right. \\
\text { Rounded totals include small amounts from facilities not listed. } \\
\text { Parent-daughter equilibrium assumed. }\end{array}$} \\
\hline
\end{tabular}

\subsection{NONRADIOACTIVE EFFLUENTS}

\section{Airborne}

Nitrogen and sulfur dioxide releases are monitored at relevant INEEL facilities (Table 7-3). Two oxides of nitrogen, nitrogen oxide (NO) and nitrogen dioxide $\left(\mathrm{NO}_{2}\right)$, are collectively referred to as $\mathrm{NO}_{\mathrm{x}}$. For the years 1993 through 1995, the data in Table 7-3 were based on data from the
INEEL Industrial Waste Management Information System. Emissions of nitrogen and sulfur dioxides from fuel were calculated using emission factors developed by the Environmental Protection Agency, and the amount of fuel used at each facility. For the years 1993 through 1995, data were reported as $\mathrm{NO}_{2}$. Data for 1996 and 1997 were obtained from the INEEL Air Emission Inventory [Reference 7-3], where the data are reported as total nitrogen oxides, or $\mathrm{NO}_{\mathrm{x}}$. 
TABLE 7-2. RADIONUCLIDE COMPOSITION OF LIQUID EFFLUENTS RELEASED ONSITE (1997)

\begin{tabular}{|c|c|c|c|c|}
\hline \multirow[b]{2}{*}{ Radionuclide } & \multirow[b]{2}{*}{ Half-Life } & \multicolumn{3}{|c|}{ Liquid Effluent $(\mathrm{Ci})^{\mathrm{a}}$} \\
\hline & & INTEC & TRA & Total $^{\mathbf{b}}$ \\
\hline Gross Beta & - & - & 0.5 & 0.5 \\
\hline${ }^{3} \mathrm{H}$ & $12.3 \mathrm{yr}$ & -- & 96.3 & 96.3 \\
\hline${ }^{51} \mathrm{Cr}$ & $27.8 \mathrm{~d}$ & -- & 2.4 & 2.4 \\
\hline${ }^{60} \mathrm{Co}$ & $5.27 \mathrm{yr}$ & - & 0.4 & 0.4 \\
\hline${ }^{181} \mathrm{Hf}$ & $42.4 \mathrm{~d}$ & - & $8.1 \times 10^{-2}$ & $8.1 \times 10^{-2}$ \\
\hline${ }^{90} \mathrm{Sr}$ & $28.6 \mathrm{yr}$ & $2.1 \times 10^{-2}$ & $9.6 \times 10^{-3}$ & $3.1 \times 10^{-2}$ \\
\hline${ }^{137} \mathrm{Cs}$ & $30.2 \mathrm{yr}$ & - & $1.7 \times 10^{-2}$ & $1.7 \times 10^{-2}$ \\
\hline${ }^{239} \mathrm{Pu}$ & $87.7 \mathrm{yr}$ & $3.5 \times 10^{-3}$ & -- & $3.5 \times 10^{-3}$ \\
\hline All Others & -- & - & $6.0 \times 10^{-2}$ & $6.0 \times 10^{-2}$ \\
\hline Grand Totals & -- & $2.5 \times 10^{-2}$ & 99.8 & 99.8 \\
\hline
\end{tabular}

Eight hundred and sixty Megagrams $(\mathrm{Mg})$ (950 tons) of $\mathrm{NO}_{\mathrm{x}}$ were released during 1997, the majority coming from the New Waste Calcining Facility (NWCF) within the INTEC. The NWCF operated for approximately six months during 1997 . This facility calcines liquid radioactive waste into a more stable solid waste form. This process results in large amounts of nitrogen oxides released [Reference 7-3]. A total of 101 $\mathrm{Mg}$ (111 tons) of $\mathrm{SO}_{2}$ was released during 1997 (Table 7-3).

Using estimates of atmospheric dispersion calculated by NOAA using the MESODIF model (Figure 8-1), the locations and magnitudes of the maximum annual average concentrations of $\mathrm{NO}_{2}$ and $\mathrm{SO}_{2}$ were calculated. For $\mathrm{NO}_{2}$, the boundary concentration was calculated to be $1.30 \mu \mathrm{g} / \mathrm{m}^{3}$, a value $1.3 \%$ of the $100 \mu \mathrm{g} / \mathrm{m}^{3}$ national primary ambient air quality standard. The boundary concentration for $\mathrm{SO}_{2}$ was $0.16 \mu \mathrm{g} / \mathrm{m}^{3}$, a value $0.2 \%$ of the $80 \mu \mathrm{g} / \mathrm{m}^{3}$ national primary ambient air quality standard.

ANL-W. Emissions from the Experimental Breeder Reactor II Auxiliary Boilers do not require continuous monitoring because they are below the state of Idaho's 250 million BTU/hour emission limit. Monitoring occurs monthly with a portable stack emission monitor as an efficiency check and to ensure $\mathrm{NO}_{\mathrm{x}}$ and $\mathrm{SO}_{2}$ emissions are below state-imposed standards. During 1997, the $\mathrm{NO}_{\mathrm{x}}$ emissions ranged from 11 to 200 $\mathrm{mg} / \mathrm{m}^{3}$ ( 6 to 106 parts per million) and $\mathrm{SO}_{2}$ emissions ranged from 0 to $68 \mathrm{mg} / \mathrm{m}^{3}$ ( 0 to 36 parts per million).

\section{Liquid}

In 1986, a Nonradiological Liquid Effluent Monitoring Program was instituted to provide environmental monitoring for nonradioactive parameters and pollutants in liquid wastes generated by INEEL facilities.

Nonradioactive liquid effluents are disposed primarily to the following areas on the INEEL: an industrial waste ditch and evaporative sewage lagoon at NRF; lined sewage lagoons at the SMCF; seepage ponds at the TSF, TRA, INTEC, and WRRTF; an industrial waste pond at ANL-W; and sewage treatment facilities at various locations. Injection wells and the Big Lost River are not used as repositories for any liquid wastes, except for storm water runoff. 


\begin{tabular}{|c|c|c|c|c|c|c|c|c|c|c|}
\hline \multicolumn{11}{|c|}{$\begin{array}{l}\text { TABLE 7-3. SUMMARY OF NO } \text { AND SO }_{2} \text { EMISSIONS AND } \\
\text { AMBIENT MONITORING RESULTS (1993-1997) }\end{array}$} \\
\hline \multirow[b]{2}{*}{ Facility } & \multicolumn{3}{|c|}{$\left(\mathrm{Mg}^{\mathrm{b}}\right) \mathrm{NO}_{2}$} & \multicolumn{2}{|c|}{$(\mathrm{Mg}) \mathrm{NO}_{\mathrm{x}}$} & \multicolumn{5}{|c|}{$(\mathrm{Mg}) \mathrm{SO}_{2}$} \\
\hline & 1993 & 1994 & 1995 & 1996 & 1997 & 1993 & 1994 & 1995 & 1996 & 1997 \\
\hline ANL-W & 6 & 5 & 6 & 7 & 7 & 13 & 15 & 17 & 23 & 23 \\
\hline $\mathrm{CFA}$ & 2 & 1 & 1 & 5 & 3 & 5 & 3 & 2 & 10 & 7 \\
\hline INTEC (CFSGF) & 87 & 57 & 91 & 68 & 66 & 9 & 4 & 9 & 15 & 12 \\
\hline INTEC & 6 & 10 & 2 & 12 & 9 & 44 & 71 & 18 & 4 & 17 \\
\hline $\begin{array}{l}\text { INTEC (main } \\
\text { stack) }\end{array}$ & 467 & --- & --- & --- & 640 & --- & --- & -- & --- & --- \\
\hline $\mathrm{NRF}$ & 18 & 13 & 10 & 7 & 5 & 40 & 60 & 39 & 25 & 2 \\
\hline $\mathrm{PBF}$ & --- & --- & 0.3 & 1 & 2 & --- & --- & 1 & 1.8 & 2 . \\
\hline RWMC & --- & --- & --- & 13 & 14 & --- & --- & --- & 2.6 & 3 \\
\hline TAN & 9 & 14 & 8 & 7 & 7 & 21 & 28 & 15 & 24 & 19 \\
\hline TRA & 3 & 2 & 3 & $72^{\mathrm{c}}$ & $70^{c}$ & 7 & 7 & 9 & $12^{\mathrm{c}}$ & $11^{c}$ \\
\hline $\begin{array}{l}\text { Other Stationary } \\
\text { Sources }\end{array}$ & --- & --- & --- & 27 & 5 & --- & --- & -- & 1.8 & 0.2 \\
\hline Totals & 598 & 102 & 122 & 219 & 828 & 139 & 188 & 110 & 119 & 96 \\
\hline \multicolumn{11}{|c|}{ Ambient Monitoring $\left(\mathrm{NO}_{2} \boldsymbol{\mu \mathrm { g } / \mathrm { m } ^ { 3 } )}\right.$} \\
\hline EFS & $\overline{36}$ & 15.4 & 4.0 & 8.1 & 4.4 & -- & $-\cdots$ & $\overline{---}$ & $-\cdots$ & -- \\
\hline VANB & 9.4 & 4.9 & 3.8 & 3.0 & 6.2 & 1.8 & 2.7 & 2.1 & 4.0 & 5.2 \\
\hline
\end{tabular}

ANL-W. During 1997, the Industrial Waste Pond at ANL-W was monitored for iron, sodium, mercury, chloride, fluoride, sulfate, phosphate, temperature, dissolved oxygen, specific conductance, turbidity, and $\mathrm{pH}$. No sampling was done from February through August as there was only snow melt and precipitation in the pond during this time. The Secondary Sanitary Lagoon was monitored for biological oxygen demand, total suspended solids, dissolved oxygen, specific conductance, turbidity, temperature, iron, sodium, chloride, fluoride, sulfate, and $\mathrm{pH}$. All parameters for both ponds were well below applicable standards.

TRA. Nonradioactive liquid effluents are discharged from TRA into three types of ponds: the Cold Waste Pond, Chemical Waste Pond, and two sewage lagoons. The Cold Waste Pond receives primarily secondary cooling water from the Advanced Test Reactor. Table 7-4 summarizes the nonradiological monitoring data for effluents released into the Cold Waste Pond from TRA during 1997 [Reference 7-4]. The Chemical Waste Pond receives neutralized water from chemical treatment processes at the TRA demineralizer facility.

INTEC. Liquid effluent from INTEC, discharged to the percolation ponds since 1995 under a Waste Water Land Application Permit, consists primarily of cooling water from facility operations.

Monitoring results are presented in Table 7-5. During 1997, concentrations measured for each parameter were below any standard which would define it as hazardous effluent. 


\begin{tabular}{|c|c|c|c|c|c|}
\hline \multicolumn{6}{|c|}{$\begin{array}{l}\text { TABLE } 7.4 \\
\text { TRA LIQUID EFFLUENT INORGANIC MONITORING DATA (1997) }\end{array}$} \\
\hline \multirow[b]{2}{*}{ Parameter } & \multicolumn{4}{|c|}{ Concentration $^{\mathrm{a}}$} & \multirow[b]{2}{*}{$\frac{\text { Toxicity }}{\text { Limit }^{\mathrm{b}}}$} \\
\hline & February & $\underline{\text { May }}$ & August & November & \\
\hline Conductivity & 260 & 763 & 172 & 718 & $\bar{\cdots}$ \\
\hline $\mathrm{pH}$ & 7.4 & 7.4 & 7.3 & 7.3 & 2 to 12.5 \\
\hline Total Dissolved Solids & 264 & 820 & 300 & 780 & --- \\
\hline Chloride Ion & $8.8^{\circ}$ & 45.8 & 13.3 & 31.9 & -- \\
\hline Fluoride Ion & 0.1 & 0.4 & 0.2 & 0.4 & -- \\
\hline Nitrate as Nitrogen & 1.1 & 4.0 & 1.4 & 2.5 & -- \\
\hline Sulfate & 28.4 & 386 & 54.3 & 362 & -- \\
\hline Silver & $<\mathrm{dl}^{\mathrm{c}}$ & $<\mathrm{dl}$ & $<\mathrm{dl}$ & $<\mathrm{dl}$ & 5 \\
\hline Arsenic & $<\mathrm{dl}$ & $<\mathrm{dl}$ & $<\mathrm{dl}$ & $<\mathrm{dl}$ & 5 \\
\hline Barium & 0.05 & 0.12 & 0.05 & 0.10 & 100 \\
\hline Beryllium & $<\mathrm{dl}$ & $<\mathrm{dl}$ & $<\mathrm{dl}$ & $<\mathrm{dl}$ & - \\
\hline Calcium & 464 & 143 & $N^{d}$ & ND & -- \\
\hline Cadmium & $<\mathrm{dl}$ & $<\mathrm{dl}$ & $<\mathrm{dl}$ & $<\mathrm{dl}$ & 1 \\
\hline Cobalt & $<\mathrm{dl}$ & $<\mathrm{dl}$ & $<\mathrm{dl}$ & $<\mathrm{dl}$ & -- \\
\hline Chromium & $<\mathrm{dl}$ & 0.005 & 0.008 & $<\mathrm{dl}$ & 5 \\
\hline Copper & $<\mathrm{dl}$ & 0.009 & 0.005 & 0.012 & -- \\
\hline Iron & 0.007 & 0.05 & 0.03 & 0.10 & --- \\
\hline Mercury & $<\mathrm{dl}$ & $<\mathrm{dl}$ & $<\mathrm{dl}$ & $<\mathrm{dl}$ & 0.2 \\
\hline Potassium & 1.4 & 8.1 & 2.2 & 7.4 & --- \\
\hline Magnesium & 17.2 & 49.6 & 22.0 & 43.8 & -- \\
\hline Manganese & $<\mathrm{dl}$ & 0.002 & $<\mathrm{dl}$ & 0.001 & --- \\
\hline Sodium & 8.3 & 25.2 & 10.4 & 21.2 & --- \\
\hline Nickel & $<\mathrm{dl}$ & $<\mathrm{dl}$ & $<\mathrm{dl}$ & $<\mathrm{dl}$ & --- \\
\hline Lead & $<\mathrm{dl}$ & $<\mathrm{dl}$ & $<\mathrm{dl}$ & $<\mathrm{dl}$ & 5 \\
\hline Antimony & $<\mathrm{dl}$ & $<\mathrm{dl}$ & $<\mathrm{dl}$ & $<\mathrm{dl}$ & $-\cdots$ \\
\hline Selenium & $<\mathrm{dl}$ & $<\mathrm{dl}$ & $<\mathrm{dl}$ & $<\mathrm{dl}$ & 1 \\
\hline Thallium & 0.04 & $<\mathrm{dl}$ & $<\mathrm{dl}$ & $<\mathrm{dl}$ & --- \\
\hline Zinc & 0.002 & 0.007 & 0.006 & 0.003 & $\cdots$ \\
\hline \multicolumn{6}{|c|}{$\begin{array}{l}\text { Concentrations in } \mathrm{mg} / \mathrm{L} \text { except Conductivity }(\mu \mathrm{S}) \text { and } \mathrm{pH} \text { (no units). } \\
\text { EPA maximum concentration of contaminants for the toxicity characteristic from } 40 \text { CFR 261.24. A blank (- } \\
\text {--) in this column means no limit has been established. } \\
\text { c Concentration below the detection limit. } \\
\text { d No data available for this sampling event. }\end{array}$} \\
\hline
\end{tabular}

Naval Reactors Facility (NRF). Liquid effluent monitoring confirmed all discharges in 1977 were controlled in accordance with applicable federal and state laws. Specifics regarding this monitoring are published in the NRF Environmental Monitoring Report for Calendar Year 1997. 


\begin{tabular}{|c|c|c|c|c|c|c|c|c|c|c|c|c|c|}
\hline \multicolumn{14}{|c|}{$\begin{array}{c}\text { TABLE 7-5. INTEC SERVICE WASTE INORGANIC } \\
\text { MONITORING DATA (1997) }\end{array}$} \\
\hline Parameter & $\underline{\operatorname{Jan}}$ & Feb & Mar & Apr & May & Jun & $\underline{\text { Jul }}$ & Aug & Sep & Oct & Nov & Dec & $\begin{array}{c}\text { Toxicity } \\
\text { Limit }\end{array}$ \\
\hline Aluminum & $<\mathrm{dl}^{\mathrm{b}}$ & $<\mathrm{dl}$ & $<\mathrm{dl}$ & $<\mathrm{dl}$ & $<\mathrm{dl}$ & $<\mathrm{dl}$ & 0.05 & $<\mathrm{dl}$ & $<\mathrm{dl}$ & $<\mathrm{dl}$ & $\overline{<\mathrm{dl}}$ & $<\mathrm{dl}$ & $\mathrm{N} / \mathrm{A}$ \\
\hline Arsenic & $<\mathrm{dl}$ & $<\mathrm{dl}$ & $<\mathrm{dl}$ & $<\mathrm{dl}$ & $<\mathrm{dl}$ & $<\mathrm{dl}$ & $<\mathrm{dl}$ & $<\mathrm{dl}$ & $<\mathrm{dl}$ & $<\mathrm{dl}$ & $<\mathrm{dl}$ & 0.004 & 5 \\
\hline Barium & 0.11 & 0.07 & 0.10 & 0.10 & 0.70 & 0.05 & 0.03 & 0.10 & 0.20 & 0.09 & 0.0008 & 0.08 & \\
\hline Cadmium & $<\mathrm{dl}$ & $<\mathrm{dl}$ & $<\mathrm{dl}$ & $<\mathrm{dl}$ & $<\mathrm{dl}$ & $<\mathrm{dl}$ & $<\mathrm{dl}$ & $<\mathrm{dl}$ & $<\mathrm{dl}$ & $<\mathrm{dl}$ & $<\mathrm{dl}$ & $<\mathrm{dl}$ & 1 \\
\hline Chromium & 0.013 & $<\mathrm{dl}$ & 0.006 & $<\mathrm{dl}$ & $<\mathrm{dl}$ & $<\mathrm{dl}$ & $<\mathrm{dl}$ & 0.016 & $<\mathrm{dl}$ & $<\mathrm{dl}$ & $<\mathrm{dl}$ & 0.008 & 5 \\
\hline Copper & 0.007 & 0.01 & 0.01 & $<\mathrm{dl}$ & 0.007 & $<\mathrm{dl}$ & 0.007 & $<\mathrm{dl}$ & $<\mathrm{dl}$ & $<\mathrm{dl}$ & 0.009 & 0.008 & N/A \\
\hline Mercury & $<\mathrm{dl}$ & $<\mathrm{dl}$ & $<\mathrm{dl}$ & $<\mathrm{dl}$ & $<\mathrm{dl}$ & $<\mathrm{dl}$ & $<\mathrm{dl}$ & $<\mathrm{dl}$ & $<\mathrm{dl}$ & $<\mathrm{dl}$ & $<\mathrm{dl}$ & $<\mathrm{dl}$ & 0.2 \\
\hline Selenium & 0.03 & $<\mathrm{dl}$ & $<\mathrm{dl}$ & $<\mathrm{dl}$ & $<\mathrm{dl}$ & $<\mathrm{dl}$ & $<\mathrm{dl}$ & $<\mathrm{d} 1$ & $<\mathrm{dl}$ & $<\mathrm{dl}$ & $<\mathrm{dl}$ & $<\mathrm{dl}$ & 1 \\
\hline Silver & $<\mathrm{dl}$ & $<\mathrm{dl}$ & $<\mathrm{dl}$ & $<\mathrm{dl}$ & 0.005 & $<\mathrm{dl}$ & $<\mathrm{dl}$ & $<\mathrm{dl}$ & $<\mathrm{dl}$ & $<\mathrm{dl}$ & $<\mathrm{dl}$ & $<\mathrm{dl}$ & 5 \\
\hline Sodium & 160 & 173 & 167 & 158 & 155 & 132 & 115 & 163 & 191 & 163 & 124 & 155 & N/A \\
\hline Chloride & 308 & 295 & 292 & 273 & 215 & 213 & 112 & 293 & 344 & 278 & 235 & 250 & N/A \\
\hline Fluoride & $<\mathrm{dl}$ & $<\mathrm{dl}$ & $<\mathrm{dl}$ & 0.21 & $<\mathrm{dl}$ & 0.24 & 0.24 & 0.25 & 0.24 & 0.29 & 0.24 & 0.23 & N/A \\
\hline Iron & 0.04 & 0.04 & 0.01 & 0.005 & 0.008 & $<\mathrm{dl}$ & 0.06 & 0.08 & 0.02 & 0.20 & 0.05 & 0.03 & N/A \\
\hline Manganese & 0.002 & $<\mathrm{dl}$ & 0.002 & $<\mathrm{dl}$ & $<\mathrm{dl}$ & $<\mathrm{dl}$ & $<\mathrm{dl}$ & $<\mathrm{dl}$ & $<\mathrm{dl}$ & $<\mathrm{dl}$ & 0.002 & 0.004 & N/A \\
\hline Nitrate & 5.0 & 5.20 & 1.10 & 1.0 & 1.10 & 1.0 & 1.0 & 1.0 & 0.92 & 0.94 & 1.10 & 1.20 & N/A \\
\hline Nitrite & $<\mathrm{dl}$ & $<\mathrm{dl}$ & $<\mathrm{dl}$ & $<\mathrm{dl}$ & $<\mathrm{dl}$ & $<\mathrm{dl}$ & $<\mathrm{dl}$ & $<\mathrm{dl}$ & $<\mathrm{dl}$ & $<\mathrm{dl}$ & $<\mathrm{dl}$ & $<\mathrm{dl}$ & N/A \\
\hline $\operatorname{TDS}^{c}$ & 696 & 584 & 702 & 658 & 575 & 558 & 401 & 627 & 692 & 603 & 593 & 657 & N/A \\
\hline $\mathrm{pH}$ & 8.4 & 8.4 & 8.5 & 8.3 & 8.3 & 8.2 & 8.4 & 8.4 & 8.1 & 8.3 & 8.4 & 8.3 & $2-12.5$ \\
\hline $\mathrm{TKN}^{\mathrm{d}}$ & 0.25 & 0.16 & $<\mathrm{dl}$ & 0.19 & $<\mathrm{dl}$ & 0.22 & 0.10 & 0.21 & $<\mathrm{dl}$ & 0.14 & $<\mathrm{dl}$ & 0.16 & $\mathrm{~N} / \mathrm{A}$ \\
\hline c & 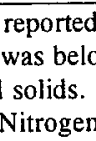 & & LM & & & & & & & & & & \\
\hline
\end{tabular}




\section{Summary of Chapter 8 \\ Dose to the Public}

In the course of some operations at the Idaho National Engineering and Environmental Laboratory (INEEL), radioactive materials may be released to the environment. These radioactive materials have the potential to provide a dose to individuals that live and work at offsite locations. Potential doses may result from the immersion, ingestion, and inhalation of radioactive materials released into the atmosphere and transported offsite (Section 8.1).

This chapter presents an evaluation of the potential doses received from INEEL operations by the public. Two separate computer models are used to determine the hypothetical maximally-exposed individual (Section 8.2), based on the amount of radioactivity released to the air and meteorological data. In 1997, one model predicted this individual would reside at Frenchman's Cabin at the southern INEEL boundary, and would have received a dose of $0.03 \mathrm{mrem}$. The other model predicted a dose of $0.02 \mathrm{mrem}$ to the maximally-exposed individual, who would have resided near Howe, Idaho. These numbers can be compared to the approximately 360 mrem dose received by residents of southeast Idaho from background sources during the year.

A second potential exposure pathway to the population residing near the INEEL is through ingestion of game animals that migrate across or live on the Site (Section 8.3). This pathway was evaluated for waterfowl and mourning doves in 1997. A potential dose from anthropogenic radionuclides of $1.4 \mathrm{mrem}$ was calculated for the duck with the highest concentration of these radionuclides in edible tissues. This duck was collected from a radioactive waste disposal pond at the Test Reactor Area. For doves, a potential dose of 0.02 mrem was calculated, also from a bird taken from the Test Reactor Area. Both of the calculated doses were significantly lower than those obtained in previous studies of INEEL waste ponds.

A computer model and census data were used to calculate the theoretical dose to the population that lives within $80 \mathrm{~km}(50 \mathrm{mi})$ of the INEEL's center of operations ( $\mathrm{Sec}$ tion 8.3). For 1997, a calculated dose of 0.23 person-rem was obtained using the model for a population of approximately 121,500 . This same population received an estimated dose of 42,500 person-rem from background sources during the year. 



\section{DOSE TO THE PUBLIC}

\subsection{GENERAL INFORMATION}

Typically the radiological impact of INEEL operations on the public surrounding the INEEL has been too small to be measured by routine monitoring programs. Because of this, radiological impacts resulting from INEEL operations have been estimated using the reported amounts of radionuclides released during the year from INEEL facilities and appropriate air dispersion models to estimate the concentrations of radionuclides at selected locations surrounding the INEEL. During 1997, this was accomplished for the radionuclides summarized in Table 7-1.

The following estimates were calculated:

- the effective dose equivalent to the maximallyexposed individual residing offsite using the CAP-88 model;

- the effective dose equivalent to the maximallyexposed individual residing offsite using dispersion calculations from the MDIFF (mesoscale diffusion) model [Reference 8-1]; and

- the collective effective dose equivalent (population dose) within an $80-\mathrm{km}(50-\mathrm{mi})$ radius of the operations center of the Site (the Test Reactor Area [TRA] and the Idaho Nuclear Technology and Engineering Center [INTEC]). The estimated population dose was based on the effective dose equivalent calculated with the MDIFF air dispersion model for the maximally-exposed individual.

In this chapter, the term dose will refer to effective dose equivalent unless another term is specifically stated. Dose was calculated by summing the committed dose equivalents to organs, each multiplied by a weighting factor proportional to each organ's sensitivity to radiation. Effective dose equivalent includes doses received from both external and internal sources and represents the same risk as if an individual's body were uniformly irradiated. U.S. Department of Energy (DOE) dose conversion factors and a 50-year integration period were used for internally deposited radionuclides [Reference 8-2] and for radionuclides deposited on ground surfaces [Reference 8-3] in calculations with both air dispersion models. Because the hypothetical dose to the maximally-exposed individual residing near the INEEL is so low, no allowance is made in the MDIFF model for shielding by housing materials, which is estimated to reduce the dose by about $30 \%$. Neither was less-than-year-round occupancy time in the community. The CAP- 88 model, used by all sites regardless of the magnitude of the hypothetical dose, includes a factor to allow for shielding by housing materials and occupancy time.

Of the potential exposure pathways by which radioactive materials from INEEL operations could be transported offsite, atmospheric transport is likely to be the principal potential pathway. This is the likely exposure pathway since radionuclides from the INEEL have not been found in drinking water wells offsite. Because of this, the maximally-exposed individual dose is determined through the use of models using the airborne emissions pathway.

\subsection{MAXIMUM INDIVIDUAL DOSE - AIRBORNE EMISSIONS PATHWAY}

\section{CAP-88 Model}

\section{During 1997, U.S. Environmental Protection} Agency (EPA) regulations were in effect that limit quantities of airborne radionuclides released from any nuclear facility. The standard required the dose received by any member of the public must be less than $10 \mathrm{mrem} / \mathrm{yr}$, as determined using the CAP- 88 computer model. 
For the 1997 calculations at the INEEL, approximately 60 potential maximum locations were evaluated. The CAP-88 model predicted the highest dose to be at Frenchman's Cabin, located at the southern boundary of the INEEL. Although this location is only inhabited during portions of the year, it meets the EPA definition of a residence. At Frenchman's Cabin, a hypothetical dose of $0.03 \mathrm{mrem}\left(3 \times 10^{-4} \mathrm{mSv}\right)$ was calculated. The largest contributions to this dose came from ${ }^{129}$ I from INTEC, which accounted for about $69 \%$, and diffuse sources of radioactivity at the Radioactive Waste Management Complex, accounting for about $15 \%$. The dose of 0.03 mrem is $0.3 \%$ of the EPA radiation protection standard.

\section{MDIFF Model}

The MDIFF (formerly known as MESODIF) air dispersion model has been in use for over 20 years to calculate doses to members of the public residing near the INEEL. The MDIFF diffusion curves, developed from tests in desert environments (i.e. INEEL and the Hanford Site in eastern Washington) may be more appropriate for the INEEL than CAP-88. In previous years, doses calculated with the MDIFF air dispersion model have been somewhat higher than doses calculated using CAP-88. Differences between the two models were discussed in detail in the 1986 annual report [Reference 8-4]. The offsite concentrations calculated using both models were compared to actual monitoring results at offsite locations in 1986, 1987, and 1988. Concentrations calculated for several locations using the MDIFF model showed good agreement with concentrations from actual measurements, with the model generally predicting concentrations higher than those measured [References 8-5, 8-6, and 8-7].

The mesoscale map (Figure 8-1) shows the calculated 1997 concentrations normalized to a unit release rate for the TRA and INTEC. This map was prepared by the National Oceanic and Atmospheric Administration Air Resources Laboratory (NOAA-ARL) using the MDIFF model and data gathered continuously at meteorological stations on and around the INEEL. To obtain the average air concentration $\left(\mathrm{Ci} / \mathrm{m}^{3}\right)$ for a radionuclide released from TRA and INTEC along any dispersion coefficient isopleth (line of equal air concentration) in Figure 8-1, the value of the 1997 average dispersion coefficient is multiplied by the number of curies of the radionuclide released during 1997 and divided by the square of the number of hours in a year $\left(7.67 \times 10^{7}\right)$. NOAA-ARL also prepared a similar map of dispersion coefficients for ANL-W; however, calculations using these coefficients and the 1997 emissions from ANL-W indicated the maximum possible doses from ANL-W were three to four orders of magnitude lower than those from TRA/INTEC and contributed negligibly to the total.

The MDIFF model predicts that the highest concentrations of radionuclides in the air at an inhabited area during 1997 would have occurred at Howe, Idaho. The maximum hypothetical dose was calculated for an adult resident of that location from inhalation of air, submersion in air, ingestion of radioactivity on leafy vegetables, ingestion of milk, and exposure due to deposition of radioactive particles on ground surfaces. The calculation was based on data presented in Table 7-1 and in Figure 8-1.

Using the calculated dispersion coefficient of $30 \times 10^{-9}$ (the largest dispersion coefficient value from TRA/INTEC at a location inhabited by a full-time resident) and allowing for radioactive decay during the 26- $\mathrm{km}$ (16-mi) transit of the radionuclides from TRA/NTEC to Howe, the potential effective dose equivalent from all radionuclides released was calculated to be 0.021 mrem $\left(2.1 \times 10^{-4} \mathrm{mSv}\right)$ (Table 8-1). This dose is $0.021 \%$ of the DOE radiation protection standard for a prolonged period of exposure to a member of the public from all pathways and $0.21 \%$ of the EPA standard for the airborne pathway only.

Of the dose received, the ingestion pathway accounted for $81 \%$ of the total, with the immersion pathway accounting for $12 \%$. Figure 8-2 
illustrates the contribution of the most significant radionuclides to the maximum individual dose for $1997 ;{ }^{129}$ I contributed approximately $87.5 \%$ of the total, and ${ }^{41} \mathrm{Ar}$ contributed $11.5 \%$.

There are differences in the atmospheric dispersion portions of the MDIFF and CAP-88 air dispersion codes. CAP- 88 makes its calculations based on the joint frequency of wind conditions from a single wind station located near the source. MDIFF calculates the individual trajectories using winds from about 30 towers in the Upper Snake River Plain. For this reason the two models may not agree on the location of the maximum dose.
The calculated maximum dose resulting from INEEL operations is very small compared to the average dose received by individuals in southeastern Idaho from cosmic and terrestrial sources of naturally-occurring radiation found in the environment. The total annual dose from all natural sources is estimated at approximately 360 mrem (Table 4-11),

\subsection{MAXIMUM INDIVIDUAL DOSE - GAME INGESTION PATHWAY}

The potential dose an individual may receive from the occasional ingestion of meat from game animals continues to be investigated at the

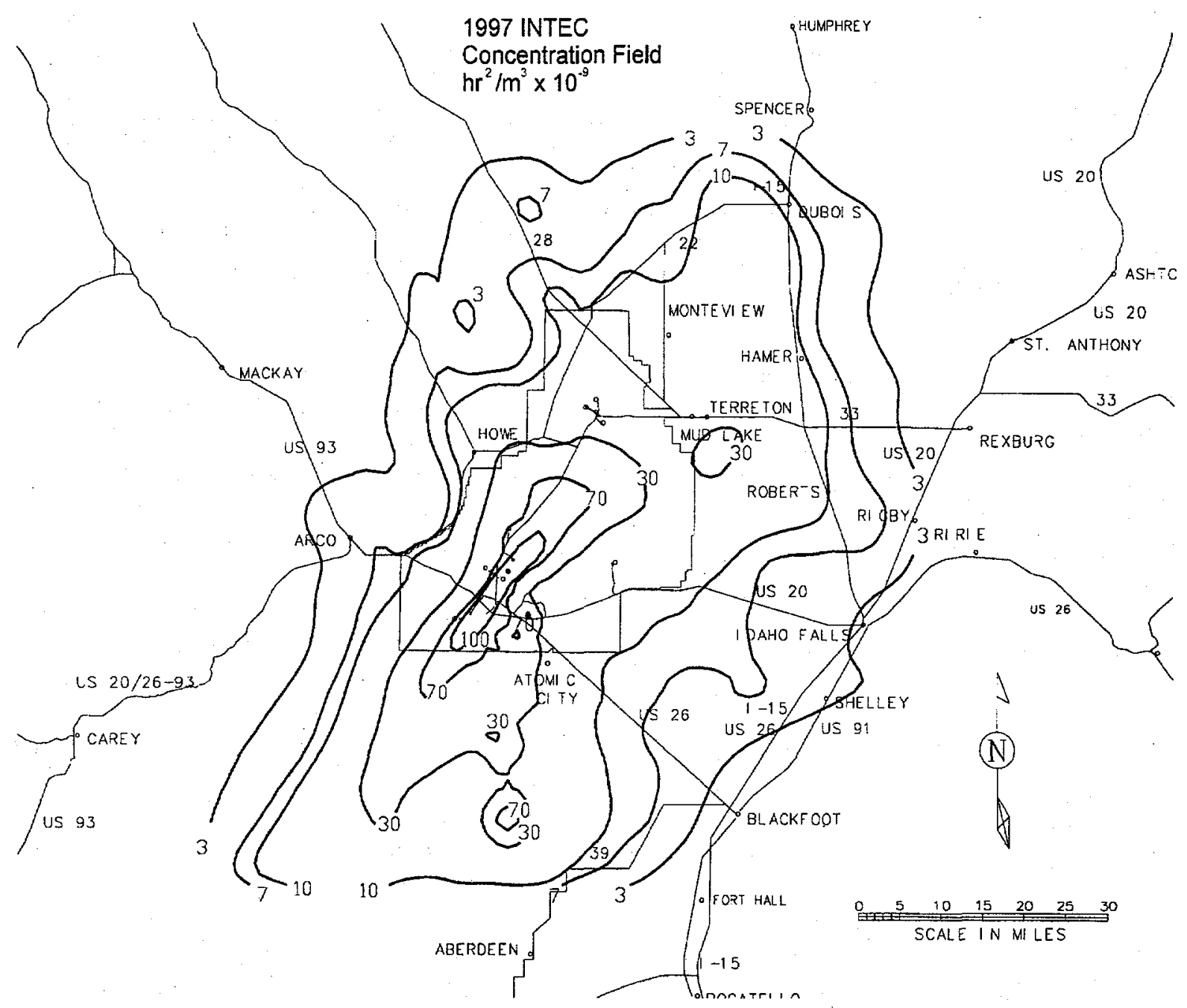

Figure 8-1. Average Mesoscale Dispersion Isopleths of Air Concentrations at Ground Level, Normalized to Unit Release Rate for TRAINTEC 


\begin{tabular}{|c|c|c|c|}
\hline \multicolumn{4}{|c|}{$\begin{array}{l}\text { TABLE 8-1. MAXIMUM INDIVIDUAL EFFECTIVE } \\
\text { DOSE EQUIVALENT (1997) }\end{array}$} \\
\hline \multirow[b]{2}{*}{ Radionuclide $^{\mathrm{a}}$} & \multirow{2}{*}{$\begin{array}{c}\text { Maximum Offsite } \\
\text { Concentration }(\mu \mathrm{Ci} / \mathrm{mL})^{b}\end{array}$} & \multicolumn{2}{|c|}{ Maximum Effective Dose Equivalent ${ }^{\mathfrak{c}}$} \\
\hline & & mrem & $\underline{\mathbf{m S v}}$ \\
\hline${ }^{129} \mathrm{I}$ & $2.3 \times 10^{-17}$ & $1.8 \times 10^{-2}$ & $1.8 \times 10^{-4}$ \\
\hline${ }^{41} \mathrm{Ar}$ & $3.6 \times 10^{-13}$ & $2.4 \times 10^{-3}$ & $2.4 \times 10^{-5}$ \\
\hline${ }^{137} \mathrm{Cs}+\mathrm{D}$ & $9.5 \times 10^{-19}$ & $4.7 \times 10^{-5}$ & $4.7 \times 10^{-7}$ \\
\hline${ }^{90} \mathrm{Sr}+\mathrm{D}$ & $1.2 \times 10^{-19}$ & $4.4 \times 10^{-5}$ & $4.4 \times 10^{-7}$ \\
\hline${ }^{3} \mathrm{H}$ & $6.0 \times 10^{-14}$ & $3.2 \times 10^{-5}$ & $3.2 \times 10^{-7}$ \\
\hline${ }^{50} \mathrm{Co}$ & $2.6 \times 10^{-19}$ & $2.6 \times 10^{-5}$ & $2.6 \times 10^{-7}$ \\
\hline${ }^{85} \mathrm{Kr}$ & $1.4 \times 10^{-12}$ & $1.6 \times 10^{-5}$ & $1.6 \times 10^{-7}$ \\
\hline${ }^{88} \mathrm{Kr}+\mathrm{D}$ & $9.9 \times 10^{-16}$ & $1.1 \times 10^{-5}$ & $1.1 \times 10^{-7}$ \\
\hline${ }^{135} \mathrm{Xe}$ & $7.3 \times 10^{-15}$ & $9.2 \times 10^{-6}$ & $9.2 \times 10^{-8}$ \\
\hline${ }^{238} \mathrm{Pu}$ & $2.0 \times 10^{-21}$ & $7.8 \times 10^{-6}$ & $7.8 \times 10^{-8}$ \\
\hline${ }^{14} \mathrm{C}$ (organic) & $3.1 \times 10^{-16}$ & $5.5 \times 10^{-6}$ & $5.5 \times 10^{-8}$ \\
\hline${ }^{88} \mathrm{Rb}$ & $1.1 \times 10^{-15}$ & $5.0 \times 10^{-6}$ & $5.0 \times 10^{-8}$ \\
\hline${ }^{87} \mathrm{Kr}$ & $3.4 \times 10^{-16}$ & $1.5 \times 10^{-6}$ & $1.5 \times 10^{-8}$ \\
\hline${ }^{131} \mathrm{I}$ & $6.2 \times 10^{-20}$ & $1.2 \times 10^{-6}$ & $1.2 \times 10^{-8}$ \\
\hline${ }^{239} \mathrm{Pu}$ & $2.4 \times 10^{-22}$ & $1.0 \times 10^{-6}$ & $1.0 \times 10^{-6}$ \\
\hline \multicolumn{4}{|c|}{$\begin{array}{l}\text { Table includes only radionuclides which contribute a dose of } 1.0 \times 10^{-6} \mathrm{mrem}\left(1.0 \times 10^{-8} \mathrm{mSv}\right) \text { or more. When indicated }(+\mathrm{D}) \text {, the } \\
\text { contribution of progeny decay products was also included in the dose calculations. } \\
\text { - Estimate of radioactive decay using the distance to the Howe area and the } 1997 \text { average wind speed in that direction. For radionuclides } \\
\text { where parent-progeny equilibria were used in dose calculations, concentration of the parent is shown. } \\
\text { Effective dose equivalent using dose conversion factors for submersion and deposition given in DOE/EH-0070 and dose conversion } \\
\text { factors for inhalation and ingestion given in DOE/EH-0071. }\end{array}$} \\
\hline
\end{tabular}

INEEL. Such studies include the potential dose to individuals who may eat waterfowl that reside briefly at waste ponds used for the disposal of low-level radioactive wastes and dose to individuals who may eat game birds and game animals which may migrate across the INEEL.

Following the construction of two hypalonlined evaporation ponds at TRA and the closure of the percolation ponds formerly used for disposal of wastes at this facility, the Environmental Science and Research Foundation initiated a study in 1994 to obtain current data on potential doses from game animals using the ponds.

During 1997, 18 waterfowl were collected from radioactive waste disposal ponds at TRA and INTEC, a pond at Test Area North (TAN) previously used for low-level waste disposal, and a sewage pond at Argonne National Laboratory West (ANL-W). Collected waterfowl included five coots, two mallards, two northern shovelers, one American wigeon, one lesser scaup, one bufflehead, and one common merganser. Five control samples were also collected from the Little Lost River (three mallards) and from the South Fork of the Snake River (one mallard and one common merganser). Radionuclide concentrations in the edible portion of the ducks reported in Tables 4-6 and 4-7 were used to estimate the potential dose to an individual consuming waterfowl from each facility. Estimated doses are based on the assumption that ducks are killed and eaten immediately after leaving the ponds. A lower dose would be more realistic due to the biological elimination of the radioactivity. For example, a significant contributor to the dose, ${ }^{137} \mathrm{Cs}$, has an effective half-life in mallard ducks of 11.2 days [Reference 8-8]. This means that half of the ${ }^{137} \mathrm{Cs}$ present in the muscle tissue of the duck would be eliminated in 11.2 days. At the end of the next 11.2 days, half of the remain- 


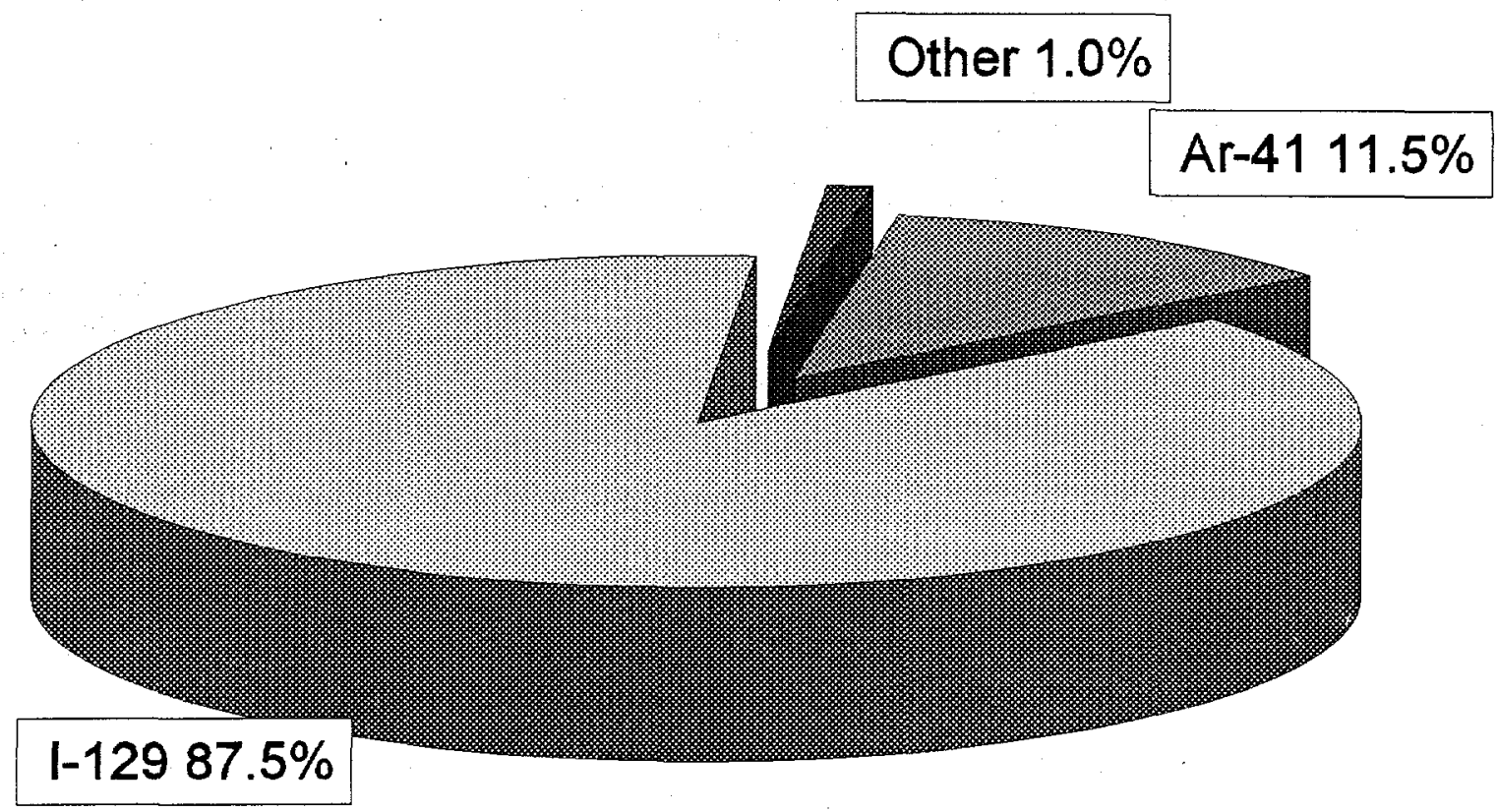

Figure 8-2. Radionuclides contributing to Maximum Individual Dose (1997)

ing radioactivity (or one-fourth of the original activity) would be remaining.

Among the doses from manmade radionuclides, the highest 1997 values were found in waterfowl collected at TRA, where a dose of 1.4 mrem was calculated (Table 8-2). This can be compared to a dose of 0.002 mrem estimated for controls. The largest anthropogenic contributors to dose were ${ }^{60} \mathrm{Co},{ }^{65} \mathrm{Zn},{ }^{90} \mathrm{Sr}$, and ${ }^{137} \mathrm{Cs}$. The potential doses from 1997 waterfowl samples are substantially reduced from the $10 \mathrm{mrem}$ average whole-body dose equivalent from gamma-emitting radionuclides estimated during a 1974 to 1978 study at the former TRA percolation pond [Reference 8-9], and from the 4.0 mrem estimated for the most contaminated duck taken from the percolation pond in 1984 to 1986 [Reference 8-10].

During 1997, a total of seven mourning doves were collected, three from the evaporation ponds at TRA and four from NTEC. Four control samples were collected near Rigby, Idaho in 1996. Manmade radionuclide concentrations in the edible portion of the doves reported in Table
4-11 were used to estimate the potential dose resulting from the ingestion of $30 \mathrm{~g}(1 \mathrm{oz})$ of the edible portion of the mourning doves (Table 8-3). The potential dose from a dove at TRA was calculated to be $0.0008 \mathrm{mrem}$, compared to $<0.0002 \mathrm{mrem}$ in the control dove. The largest anthropogenic contributors to the dose were ${ }^{124} \mathrm{Sb}$ and ${ }^{241} \mathrm{Am}$. The highest estimated potential whole-body dose equivalent to a person eating the entire muscle mass of a mourning dove from the former TRA percolation pond was $0.3 \mathrm{mrem}$ in 1974-1977 [Reference 8-11].

A conservative estimate of the potential whole-body dose that could be received from an individual eating the entire muscle and liver mass of an antelope with the highest levels of radioactivity found in these animals was estimated at 0.2 mrem in 1975 [Reference 8-12]. Game animals collected at the INEEL during the past few years have shown much lower concentrations than in 1975. Based on the highest concentration of radionuclides found in a game animal during the past several years, the potential dose is now approximately $0.03 \mathrm{mrem}$. 
Table 8-2.

MAXIMUM POTENTIAL COMMITTED (50 yr) EFFECTIVE DOSE EQUIVALENTS FROM INGESTION OF MUSCLE TISSUE OF WATERFOWL USING INEEL WASTE DISPOSAL PONDS IN 1997 ${ }^{\mathrm{a}}$ (mrem)

\begin{tabular}{|c|c|c|c|c|c|}
\hline Radionuclide & $\begin{array}{c}\text { TRA } \\
\text { Evaporation } \\
\text { Ponds }\end{array}$ & TAN TSF Pond & $\begin{array}{c}\text { ICPP } \\
\text { Percolation } \\
\text { Pond }\end{array}$ & $\begin{array}{c}\text { Argonne } \\
\text { National Lab. } \\
\text { West }\end{array}$ & $\begin{array}{l}\text { Background (S. } \\
\text { Fork Snake and } \\
\text { Little Lost } \\
\text { rivers) }\end{array}$ \\
\hline${ }^{51} \mathrm{Cr}$ & 0.0001 & 0 & $5.1 \mathrm{E}-6$ & 0 & 0 \\
\hline${ }^{58} \mathrm{Co}$ & 0.001 & 0 & 0 & 0 & 0 \\
\hline${ }^{60} \mathrm{Co}$ & 0.8 & 1.3E-5 & 0 & 0 & 0 \\
\hline${ }^{65} \mathrm{Zn}$ & 0.02 & 0.0001 & 0 & 0 & 0 \\
\hline${ }^{90} \mathrm{Sr}$ & 0.04 & 0 & 0 & 0 & 0.002 \\
\hline${ }^{95} \mathrm{Nb}$ & 0 & 0 & $7.7 \mathrm{E}-6$ & 0 & 0 \\
\hline${ }^{134} \mathrm{Cs}$ & 0.007 & 0 & 0 & 0 & 0 \\
\hline${ }^{137} \mathrm{Cs}$ & 0.6 & 0.009 & 0.002 & 0.0001 & 0.0001 \\
\hline${ }^{141} \mathrm{Ce}$ & 0 & 0 & $1.6 \mathrm{E}-5$ & 0 & 0 \\
\hline${ }^{144} \mathrm{Ce}$ & 0.001 & 0 & 0 & 0 & 0 \\
\hline${ }^{241} \mathrm{Am}$ & 0.0003 & 0 & 0.001 & 0 & 0 \\
\hline Total & 1.44 & 0.009 & 0.003 & 0.0001 & 0.0021 \\
\hline
\end{tabular}

\subsection{0-KILOMETER POPULATION DOSE}

An estimate was made of the collective effective dose equivalent (population dose) from inhalation, submersion, ingestion, and deposition that could have been received by all members of the public within an $80-\mathrm{km}(50-\mathrm{mi})$ radius of the TRA/INTEC facilities. This population dose was calculated by a computer program that multiplies the population number in each square mile by the dispersion coefficient at that point $\left(\mathrm{h}^{2} / \mathrm{m}^{3}\right)$ and the normalized dose received at the location of the maximally-exposed individual $\left(\mathrm{rem} / \mathrm{yr} / \mathrm{h}^{2} / \mathrm{m}^{3}\right)$. This gives an approximation of the dose received by the entire population in a given census division.

The average dose received per person is obtained by dividing the collective effective dose equivalent by the population in that particular census division. This calculation overestimates dose because the model (conservatively) does not account for radioactive decay of the isotopes during transport over distances greater than the 26-km (16-mi) distance from the TRA/INTEC facilities to the residence of the maximallyexposed individual located near Howe. Idaho Falls, for example, is about $66-\mathrm{km}(41-\mathrm{mi})$ from TRA/INTEC. Neither residence time nor shielding by housing was considered when calculating the MDIFF dose on which the collective dose equivalent is based. The calculation also tends to overestimate the population doses because they are extrapolated from the dose computed for the location of the potential maximallyexposed individual. This individual is potentially exposed through ingestion of contaminated leafy vegetables from his garden and ingestion of milk from cows grazing solely upon contaminated pasture grass.

The 1997 MDIFF population dose within each census division was obtained by summing the results from appropriate areas contained 


\subsection{SUMMARY}

\begin{tabular}{|c|c|c|c|}
\hline \multicolumn{4}{|c|}{$\begin{array}{c}\text { Table 8-3. } \\
\text { MAXIMUM COMMITTED (50 yr) } \\
\text { EFFECTIVE DOSE EQUIVALENTS } \\
\text { FROM INGESTION OF MUSCLE TISSUE } \\
\text { OF MOURNING DOVES USING INEEL } \\
\text { WASTE PONDS IN 1997 a (mrem) }\end{array}$} \\
\hline$\frac{\text { Radio- }}{\underline{\text { nuclide }}}$ & $\underline{\text { Bround }}^{\mathrm{broun}}$ & $\begin{array}{c}\text { TRA } \\
\text { Evaporation } \\
\text { Ponds }\end{array}$ & $\begin{array}{c}\text { ICPP } \\
\text { Percolation } \\
\text { Pond }\end{array}$ \\
\hline${ }^{54} \mathrm{Mn}$ & $0^{\circ}$ & $<0.00001$ & 0 \\
\hline${ }^{95} \mathrm{Nb}$ & $<0.0001$ & $<0.0001$ & $<0.0001$ \\
\hline${ }^{95} \mathrm{Zr}$ & $<0.0001$ & $<0.0001$ & 0 \\
\hline${ }^{124} \mathrm{Sb}$ & 0 & 0.0001 & 0.0001 \\
\hline${ }^{238} \mathrm{Pu}$ & 0 & 0 & 0.0002 \\
\hline${ }^{241} \mathrm{Am}$ & 0 & 0.0007 & 0 \\
\hline Total & $<0.0002$ & 0.0008 & 0.0003 \\
\hline $\begin{array}{l}\text { Assum } \\
\text { contair } \\
\text { radion } \\
\text { Contro }\end{array}$ & $\begin{array}{l}\text { consumptic } \\
\text { taximum ob }\end{array}$ & $\begin{array}{l}30 \mathrm{~g}(1 \mathrm{oz}) \text { of } \\
\text { ed concentratior } \\
\text { ves collected in }\end{array}$ & $\begin{array}{l}\text { tissue } \\
\text { ch }\end{array}$ \\
\hline
\end{tabular}

Table 8-5 summarizes the calculated annual effective dose equivalents from 1997 INEEL operations using both CAP-88 and MDIFF air dispersion models. A comparison is shown between these doses and the EPA airborne pathway standard, and to the estimated dose from natural background. The contribution of game animal consumption to the population dose has not been calculated because only a percentage of the population hunts game, few of the animals killed have spent time on the INEEL, and most of the animals that do migrate from the INEEL would have reduced concentrations of radionuclides in their tissues by the time they were harvested. The total population dose contribution from these pathways would, realistically, be less than the sum of population doses from inhalation of air, submersion in air, and deposition on soil.

within those divisions (Table 8-4). The total 80$\mathrm{km}(50-\mathrm{mi})$ population dose was the sum of population doses for the various census divisions. The estimated potential population dose was 0.227 person-rem $(0.00227$ person-Sv) to a population of about 121,500 . When compared with an approximate population dose of 43,700 person-rem (437 person-Sv) from natural background radiation, this represents an increase of only about $0.0005 \%$. The dose of 0.227 personrem can also be compared to the following estimated population doses for the same size population: 3,600 person-rem for medical diagnostic procedures, about 480 person-rem from exposure to highway and road construction materials or 6 to 12 person-rem for television viewing. The largest collective doses are found in the Idaho Falls and Hamer census divisions. Idaho Falls is relatively high because of its relatively high population and Hamer because it lies in the predominant downwind direction from the INEEL. 


\begin{tabular}{|c|c|c|c|}
\hline \multirow[b]{2}{*}{ Census Division } & \multirow[b]{2}{*}{ Population $^{\mathrm{a}}$} & \multicolumn{2}{|c|}{ Population Dose } \\
\hline & & Person-rem & Person-Sv \\
\hline Aberdeen & 2,760 & $9.37 \times 10^{-4}$ & $9.37 \times 10^{-6}$ \\
\hline Alridge (part) & 160 & $3.27 \times 10^{-4}$ & $3.27 \times 10^{-6}$ \\
\hline American Falls (part) & 200 & $2.04 \times 10^{-5}$ & $2.04 \times 10^{-7}$ \\
\hline Arco & 2,600 & $9.76 \times 10^{-3}$ & $9.76 \times 10^{-5}$ \\
\hline Atomic City (city) & 25 & $2.76 \times 10^{-4}$ & $2.76 \times 10^{-6}$ \\
\hline Atomic City (division) & 2,300 & $1.41 \times 10^{-3}$ & $1.41 \times 10^{-5}$ \\
\hline Blackfoot & 12,450 & $7.48 \times 10^{-3}$ & $7.48 \times 10^{-5}$ \\
\hline Carey (part) & 120 & $2.51 \times 10^{-5}$ & $2.51 \times 10^{-7}$ \\
\hline Challis (part) & 10 & $1.38 \times 10^{-6}$ & $1.38 \times 10^{-8}$ \\
\hline Firth & 3,050 & $6.24 \times 10^{-3}$ & $6.24 \times 10^{-5}$ \\
\hline Fort Hall (part) & 3,920 & $1.01 \times 10^{-3}$ & $1.01 \times 10^{-5}$ \\
\hline Hamer & 2,400 & $3.57 \times 10^{-2}$ & $3.57 \times 10^{-4}$ \\
\hline Howe & 325 & $4.18 \times 10^{-3}$ & $4.18 \times 10^{-5}$ \\
\hline Idaho Falls & 63,500 & $9.09 \times 10^{-2}$ & $9.09 \times 10^{-4}$ \\
\hline Idaho Falls, west & 1,750 & $1.35 \times 10^{-3}$ & $1.35 \times 10^{-5}$ \\
\hline Leadore (part) & 15 & $3.53 \times 10^{-5}$ & $3.53 \times 10^{-7}$ \\
\hline Lewisville-Menan (part) & 2,700 & $6.89 \times 10^{-3}$ & $6.89 \times 10^{-5}$ \\
\hline Mackay & 1,200 & $1.43 \times 10^{-3}$ & $1.43 \times 10^{-5}$ \\
\hline Moreland & 8,150 & $1.85 \times 10^{-2}$ & $1.85 \times 10^{-4}$ \\
\hline Rigby & 1,000 & $2.55 \times 10^{-3}$ & $2.55 \times 10^{-5}$ \\
\hline Roberts & 1,430 & $1.04 \times 10^{-2}$ & $1.04 \times 10^{-4}$ \\
\hline Shelley & 6,400 & $1.31 \times 10^{-2}$ & $1.31 \times 10^{-4}$ \\
\hline Ucon & 4,900 & $1.25 \times 10^{-2}$ & $1.25 \times 10^{-4}$ \\
\hline \multirow[t]{2}{*}{ West Clark } & 90 & $1.78 \times 10^{-3}$ & $1.78 \times 10^{-5}$ \\
\hline & 121,465 & $2.27 \times 10^{-1}$ & $2.27 \times 10^{-3}$ \\
\hline
\end{tabular}




\begin{tabular}{|c|c|c|c|}
\hline \multicolumn{4}{|c|}{$\begin{array}{l}\text { TABLE 8-5. SUMMARY OF ANNUAL EFFECTIVE DOSE } \\
\text { DUE TO INEEL OPERATIONS (1997) }\end{array}$} \\
\hline & \multicolumn{2}{|c|}{ Maximum Dose to an Individual ${ }^{\mathrm{a}}$} & Population Dose \\
\hline & MDIFF $^{b}$ & CAP-88' & MDIFF \\
\hline Dose & $\begin{array}{c}0.021 \mathrm{mrem} \\
\left(2.1 \times 10^{-4} \mathrm{mSv}\right)\end{array}$ & $\begin{array}{c}0.028 \mathrm{mrem} \\
\left(2.8 \times 10^{-4} \mathrm{mSv}\right)\end{array}$ & $\begin{array}{c}0.23 \text { person-rem } \\
\left(2.3 \times 10^{-3} \text { person-Sv }\right)\end{array}$ \\
\hline Location & Howe & Frenchman's Cabin & $\begin{array}{l}\text { Area within an } \\
80-\mathrm{km} \text { circle }\end{array}$ \\
\hline $\begin{array}{l}\text { Applicable Radiation } \\
\text { Protection Standard }^{d}\end{array}$ & $\begin{array}{l}10 \mathrm{mrem} \\
(0.1 \mathrm{mSv})\end{array}$ & $\begin{array}{l}10 \mathrm{mrem} \\
(0.1 \mathrm{mSv})\end{array}$ & ---- \\
\hline Percentage of Standard & $0.21 \%$ & $0.28 \%$ & ---- \\
\hline Natural Background & $\begin{array}{l}360 \mathrm{mrem} \\
(3.6 \mathrm{mSv})\end{array}$ & $\begin{array}{l}360 \mathrm{mrem} \\
(3.6 \mathrm{mSv})\end{array}$ & $\begin{array}{l}43,700 \text { person-rem } \\
\text { (437 person-Sv) }\end{array}$ \\
\hline $\begin{array}{l}\text { Percentage of } \\
\text { Background }\end{array}$ & $0.006 \%$ & $0.008 \%$ & $0.0005 \%$ \\
\hline \multicolumn{4}{|c|}{$\begin{array}{l}\text { Hypothetical dose to the maximally exposed individual residing near the INEEL. } \\
\text { Effective dose equivalent calculated using the MDIFF air dispersion model. MDIFF calculations do not consider occupancy time or } \\
\text { shielding by buildings. } \\
\text { Effective dose equivalent calculated using the CAP- } 88 \text { code. } \\
\text { Although the DOE standard for all exposure models is } 100 \mathrm{mrem} / \mathrm{y} \text { as given in DOE Order } 5400.5 \text {, DOE guidance states that DOE } \\
\text { facilities will comply with the EPA standard for the airborne pathway of } 10 \mathrm{mrem} / \mathrm{y} \text {. }\end{array}$} \\
\hline
\end{tabular}




\section{Summary of Chapter 9 \\ Quality Assurance}

The Environmental Science and Research Foundation, Lockheed Martin Idaho Technologies Company (LMITCO) and the United States Geological Survey (USGS) perform environmental monitoring at the Idaho National Engineering and Environmental Laboratory (INEEL). Each of these contractors maintains a quality assurance program which includes many quality control elements to ensure results are accurate and reliable (Section 9.1). Laboratories performing analyses for these programs maintain their own quality assurance programs. One part of a laboratory's quality assurance program is participation in a variety of intercomparison programs (Section 9.2), including those administered by the U.S. Department of Energy (DOE) Environmental Measurements Laboratory (EML), the National Institute of Standards and Technology (NIST), and the Environmental Protection Agency (EPA).

Another measure of the precision of data generated by environmental programs is gained through the use of duplicate samples. This chapter provides the results of duplicate samples collected by the Environmental Science and Research Foundation and Lockheed Martin Idaho Technologies Company (LMITCO) (Section 9.3). Data collected simultaneously at the same locations by three different organizations (the Foundation, LMITCO, and the state of Idaho) are also provided for comparison. In addition, the USGS compares data with the state of Idaho on the analysis of ground-water samples collected simultaneously. 



\section{QUALITY ASSURANCE}

\subsection{QUALITY ASSURANCE PROGRAMS}

Quality control and assurance programs are maintained by contractors conducting environmental monitoring, and by laboratories performing environmental analyses, to ensure accurate and reliable results and to maximize data completeness. Elements of typical quality control programs include the following:

- Adherence to peer-reviewed written procedures for sample collection and analytical methods;

- Documentation of program changes;

- Periodic calibration of instruments with standards traceable to the NIST;

- Chain of custody procedures;

- Equipment performance checks;

- Routine yield determinations of radiochemical procedures;

- Replicate samples to determine precision;

- Analysis of blind duplicate and replicate samples;

- Analysis of quality control standards in appropriate matrices to test accuracy;

- Analysis of reagent blanks to verify that there is no radiochemical contamination during analysis;

- Analysis of blind spike samples (samples containing a known amount of a contaminant) to verify measurement accuracy;
- Internal and external surveillance to verify quality elements; and

- Data verification and validation programs.

\subsection{LABORATORY INTERCOMPARISON PROGRAMS}

\section{General Information}

Radiological data reported in this document were obtained from several commercial, university, government, and government contractor laboratories, including the Idaho State University Environmental Assessment Laboratory (EAL), the Lockheed Martin Idaho Technologies Company Radiological Measurements Laboratory, Paragon Analytics, Inc., the DOE Radiological and Environmental Sciences Laboratory (RESL), the USGS National Water Quality Laboratory, and Quanterra, Inc. These laboratories participate in a variety of programs to ensure the quality of their analytical data.

\section{Quality Assessment Program (QAP)}

The QAP is administered by DOE's Environmental Measurements Laboratory (EML) in New York. EML prepares quality control samples containing various alpha-, beta-, and gamma-emitting nuclides in water, soil, air filter, vegetation, and tissue media and distributes them to numerous DOE contractor laboratories throughout the country. The program is an interlaboratory comparison in that results from the participants are compared with the experimentally determined results of EML. EML issues QAP reports twice per year in which the identities of participating laboratories, their results, and comparison to EML results are presented. Results from the QAP are presented in Tables 9-1 to 9-4 for laboratories used during 1997. 


\begin{tabular}{|c|c|c|c|c|c|c|c|}
\hline \multirow[b]{2}{*}{ Medium } & \multirow[b]{2}{*}{$\underline{\text { Units }}$} & \multirow[b]{2}{*}{ Radionuclide } & \multicolumn{2}{|c|}{ EAL } & \multicolumn{2}{|c|}{ EML" } & \multirow{2}{*}{$\frac{\text { EAL/EMI }}{\text { Ratio }}$} \\
\hline & & & $\frac{\text { Value }}{\text { June }}$ & June Distribution & Value & Error & \\
\hline \multirow[t]{8}{*}{ Air } & \multirow[t]{8}{*}{$\mathrm{Bq} /$ filter } & Gross alpha & 1.29 & 0.03 & 0.96 & 0.05 & 1.34 \\
\hline & & Gross beta & 0.55 & 0.02 & 0.45 & 0.03 & 1.22 \\
\hline & & ${ }^{54} \mathrm{Mn}$ & 6.2 & 0.3 & 7.6 & 0.6 & 0.81 \\
\hline & & ${ }^{57} \mathrm{Co}$ & 9.0 & 0.1 & 10.8 & 1.0 & 0.83 \\
\hline & & ${ }^{60} \mathrm{Co}$ & 4.9 & 0.7 & 5.0 & 0.3 & 0.98 \\
\hline & & ${ }^{134} \mathrm{Cs}$ & 10.3 & 0.1 & 10.9 & 1.0 & 0.95 \\
\hline & & ${ }^{137} \mathrm{Cs}$ & 6.8 & 0.1 & 8.7 & 0.8 & 0.78 \\
\hline & & ${ }^{125} \mathrm{Sb}$ & 10.6 & 0.2 & 12.3 & 1.0 & 0.86 \\
\hline \multirow[t]{3}{*}{ Soil } & \multirow[t]{3}{*}{$\mathrm{Bq} / \mathrm{kg}$} & ${ }^{40} \mathrm{~K}$ & 474 & 14 & 334 & 7 & 1.42 \\
\hline & & ${ }^{60} \mathrm{Co}$ & 0.5 & 0.2 & 1.1 & 0.1 & 0.47 \\
\hline & & ${ }^{137} \mathrm{Cs}$ & 620 & 14 & 826 & 14 & 0.75 \\
\hline \multirow{3}{*}{ Vegetation } & \multirow[t]{3}{*}{$\mathrm{Bq} / \mathrm{kg}$} & ${ }^{40} \mathrm{~K}$ & 916 & 38 & 812 & 12 & 1.13 \\
\hline & & ${ }^{60} \mathrm{Co}$ & 17.0 & 0.8 & 12.5 & 0.3 & 1.36 \\
\hline & & ${ }^{137} \mathrm{Cs}$ & 233 & 5 & 189 & 7 & 1.23 \\
\hline \multirow[t]{6}{*}{ Water } & \multirow[t]{6}{*}{$\mathrm{Bq} / \mathrm{L}$} & Gross alpha & 1232 & 38 & 1130 & 10 & 1.09 \\
\hline & & Gross beta & 552 & 23 & 744 & 10 & 0.74 \\
\hline & & ${ }^{54} \mathrm{Mn}$ & 6.2 & 1.4 & 20.9 & 0.3 & 0.30 \\
\hline & & ${ }^{55} \mathrm{Fe}$ & 21.5 & 0.6 & 235 & 20 & 0.09 \\
\hline & & ${ }^{60} \mathrm{Co}$ & 93 & 2 & 91 & 1 & 1.02 \\
\hline & & ${ }^{137} \mathrm{Cs}$ & 73 & 2 & 68 & 1 & 1.04 \\
\hline
\end{tabular}

National Institute of Standards and Technology (NIST)

RESL participates in a traceability program administered through NIST. NIST prepares several alpha-, beta-, and gamma-emitting standards, generally in liquid media, for analysis by RESL.

\section{EPA Intercomparison Studies Program}

The EPA's Environmental Monitoring Systems Laboratory in Las Vegas, Nevada, coordinates an intercomparison program for radionuclides in water. The laboratories used by contractors performing environmental monitoring at the INEEL participate in this program.

\section{Dosimetry}

To verify the quality of the environmental dosimetry program conducted by LMITCO, the Operational Dosimetry Unit has participated in
11 International Environmental Dosimeter Intercomparison Studies. The Operational Dosimetry Unit's results were within $\pm 30 \%$ of the test exposure values on all intercomparisons. Quality control of the environmental dosimetry program is maintained through internal check measurements every month.

\section{Blind Spikes}

The Foundation purchases samples spiked with various radioactive nuclides and submits these spikes, submitted as samples, to the laboratories performing the Foundation's environmental analyses. The analytical results are expected to compare to the known value to within $\pm 20 \%$ or three standard deviations.

\section{Other Programs}

INEEL contractors participate in additional performance evaluation programs, including those administered by the International Atomic 


\begin{tabular}{|c|c|c|c|c|c|c|c|}
\hline \multirow[b]{2}{*}{ Medium } & \multirow[b]{2}{*}{ Units } & \multirow[b]{2}{*}{ Radionuclide } & \multicolumn{2}{|c|}{ LMITCO } & \multicolumn{2}{|c|}{ EML* } & \multirow{2}{*}{$\begin{array}{c}\begin{array}{c}\text { LMITCO/ } \\
\text { EML }\end{array} \\
\text { Ratio }\end{array}$} \\
\hline & & & Value & Error & Value & Error & \\
\hline \multicolumn{8}{|c|}{$\begin{array}{l}\text { June Distribution } \\
7.5\end{array}$} \\
\hline \multirow{7}{*}{ Air } & $\mathrm{Bq} /$ filter & ${ }^{4} \mathrm{Mn}$ & 7.5 & 0.1 & 7.6 & 0.6 & 0.98 \\
\hline & & ${ }^{57} \mathrm{Co}$ & 10.8 & 0.5 & 10.8 & 1.0 & 1.00 \\
\hline & & ${ }^{60} \mathrm{Co}$ & 4.8 & 0.6 & 5.0 & 0.3 & 0.96 \\
\hline & & ${ }^{123} \mathrm{Sb}$ & 13.2 & 0.4 & 12 & 1 & 1.07 \\
\hline & & ${ }^{14} \mathrm{Mes}$ & 11.3 & 0.2 & 11 & 1 & 1.04 \\
\hline & & ${ }^{13} \mathrm{Cs}$ & 7.9 & 0.2 & 8.7 & 0.8 & 0.91 \\
\hline & & ${ }^{144} \mathrm{Ce}$ & 15,1 & 0.9 & 16 & 1 & 0.96 \\
\hline \multirow[t]{5}{*}{ Soil } & $\mathrm{B} q \mathrm{~kg}$ & ${ }^{40 \mathrm{~K}}$ & 422 & 12 & 334 & 7 & 1.26 \\
\hline & & 列 $\mathrm{Cs}$ & 967 & 19 & 826 & 14 & 1.17 \\
\hline & & ${ }^{235} \mathrm{Pu}$ & 0.54 & 0.22 & 0.53 & 0.11 & 1.02 \\
\hline & & ${ }^{2339} \mathrm{Pu}$ & 136 & 11 & 135 & 17 & 1.01 \\
\hline & & ${ }^{241} \mathrm{Am}$ & 5.2 & 0.7 & 5.7 & 0.5 & 0.91 \\
\hline \multirow[t]{3}{*}{ Vegetation } & $\mathrm{Bg} / \mathrm{kg}$ & ${ }^{\circ 0} \mathrm{~K}$ & 914 & 34 & 812 & 12 & 1.13 \\
\hline & & ${ }^{80} \mathrm{Co}$ & 13.4 & 0.7 & $\cdot 12.5$ & 0.3 & 1.07 \\
\hline & & ${ }^{137} \mathrm{Cs}$ & 204 & 2 & 189 & 7 & 1.08 \\
\hline \multirow[t]{7}{*}{ Water } & $\mathrm{Bq} / \mathrm{L}$ & ${ }^{\mathrm{s} M \mathrm{Mn}}$ & 25 & 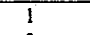 & 20.9 & 0.3 & 1.20 \\
\hline & & ${ }^{60} \mathrm{Co}$ & 106 & 2 & 91 & 1 & 1.17 \\
\hline & & ${ }^{90} \mathrm{Sr}$ & 22 & 2 & 23 & 1 & 0.94 \\
\hline & & ${ }^{19} \mathrm{Cs}$ & 79 & 3 & 70 & 1 & 1.13 \\
\hline & & ${ }^{238} \mathrm{Pu}$ & 1.59 & 0.15 & 1.29 & 0.06 & 1.23 \\
\hline & & ${ }^{239} \mathrm{Pu}$ & 0.84 & 0.11 & 0.85 & 0.05 & 0.99 \\
\hline & & ${ }^{24 i} \mathrm{Am}$ & 0.98 & 0.09 & 0.84 & 0.03 & 1.17 \\
\hline \multicolumn{8}{|c|}{ December Distribution } \\
\hline \multirow[t]{7}{*}{ Air } & Bq/filter & ${ }^{{ }^{4} \mathrm{Mn}}$ & 5.8 & 0.3 & 6.7 & 0.3 & 0.86 \\
\hline & & ${ }^{77} \mathrm{Co}$ & 11.0 & 0.2 & 12.6 & 0.4 & 0.87 \\
\hline & & ${ }^{80} \mathrm{Co}$ & 8.9 & 0.4 & 10.7 & 1.1 & 0.82 \\
\hline & & ${ }^{123} \mathrm{Sb}$ & 16.1 & 0.2 & 16.1 & 0.8 & 0.99 \\
\hline & & ${ }^{14} \mathrm{Cs}$ & 24.3 & 0.6 & 28.2 & 0.7 & 0.86 \\
\hline & & ${ }^{137} \mathrm{Cs}$ & 5.9 & 0.2 & 7.3 & 0.3 & 0.80 \\
\hline & & ${ }^{i 4} \mathrm{Ce}$ & 16.0 & 0.5 & 19.1 & 0.7 & 0.83 \\
\hline \multirow[t]{6}{*}{ Soil } & $\mathrm{Bq} / \mathrm{kg}$ & ${ }^{40} \mathrm{~K}$ & 294 & 6 & 315 & 20 & 0.93 \\
\hline & & ${ }^{90} \mathrm{SI}_{\mathrm{I}}$ & 90 & 16 & 35 & 1 & 2.58 \\
\hline & & ${ }^{\mathrm{m}} \mathrm{Cs}$ & 884 & 9 & 810 & 40 & 1.09 \\
\hline & & ${ }^{239} \mathrm{pu}$ & 11.7 & 1.2 & 10.2 & 0.4 & 1.15 \\
\hline & & ${ }^{204} \mathrm{Am}$ & 7.9 & 1.4 & 6.0 & 0.6 & 1.30 \\
\hline & & UBO & 87 & 12 & 72.9 & 0.8 & 1.19 \\
\hline \multirow[t]{3}{*}{ Vegetation } & Bq/kg & ${ }^{\circ 0 \mathrm{~K}}$ & 1250 & 70 & 1130 & 70 & 1.10 \\
\hline & & ${ }^{80} \mathrm{Co}$ & 37 & 2 & 32 & 2 & 1.13 \\
\hline & & ${ }^{137} \mathrm{Cs}$ & 669 & 3 & 624 & 31 & 1.07 \\
\hline \multirow[t]{9}{*}{ Water } & $\mathrm{Bg} / \mathrm{L}$ & ${ }^{54} \mathrm{Mn}$ & 44 & 1 & 38 & 2 & 1.15 \\
\hline & & ${ }^{60} \mathrm{Ca}$ & 26.3 & 0.2 & 23.3 & 1.2 & 1.12 \\
\hline & & ${ }^{90} \mathrm{SI}$ & 3.4 & 0.2 & 2.9 & 0.2 & 1.15 \\
\hline & & ${ }^{134} \mathrm{Cs}$ & 75 & 2 & 66 & 3 & 1.13 \\
\hline & & ${ }^{13} \mathrm{Cs}$ & 37 & 2 & 34 & 2 & 1.08 \\
\hline & & ${ }^{233} \mathrm{Pu}$ & 0.69 & 0.07 & 0.72 & 0.02 & 0.95 \\
\hline & & ${ }^{293} \mathrm{Pu}$ & 0.77 & 0.08 & 0.75 & 0.04 & 1.02 \\
\hline & & ${ }^{201} \mathrm{Am}$ & 0.77 & 0.06 & 0.75 & 0.02 & 1.02 \\
\hline & & UBO & 0.57 & 0.09 & 0.48 & 0.03 & 1.18 \\
\hline
\end{tabular}

Energy Agency and the American Society for Testing and Materials. Where possible, contractors use laboratories that are certified by the state of Idaho or certified by another state whose certification is recognized by the state of Idaho.

\subsection{DATA PRECISION AND VERIFICATION}

\section{Duplicate Sampling}

As a measure of the quality of data collected, the Foundation, LMITCO, USGS and other contractors performing monitoring used a variety of quality control samples of different media. Quality control samples include duplicate samples (separate samples taken at the same time), split samples (two portions of a sample 


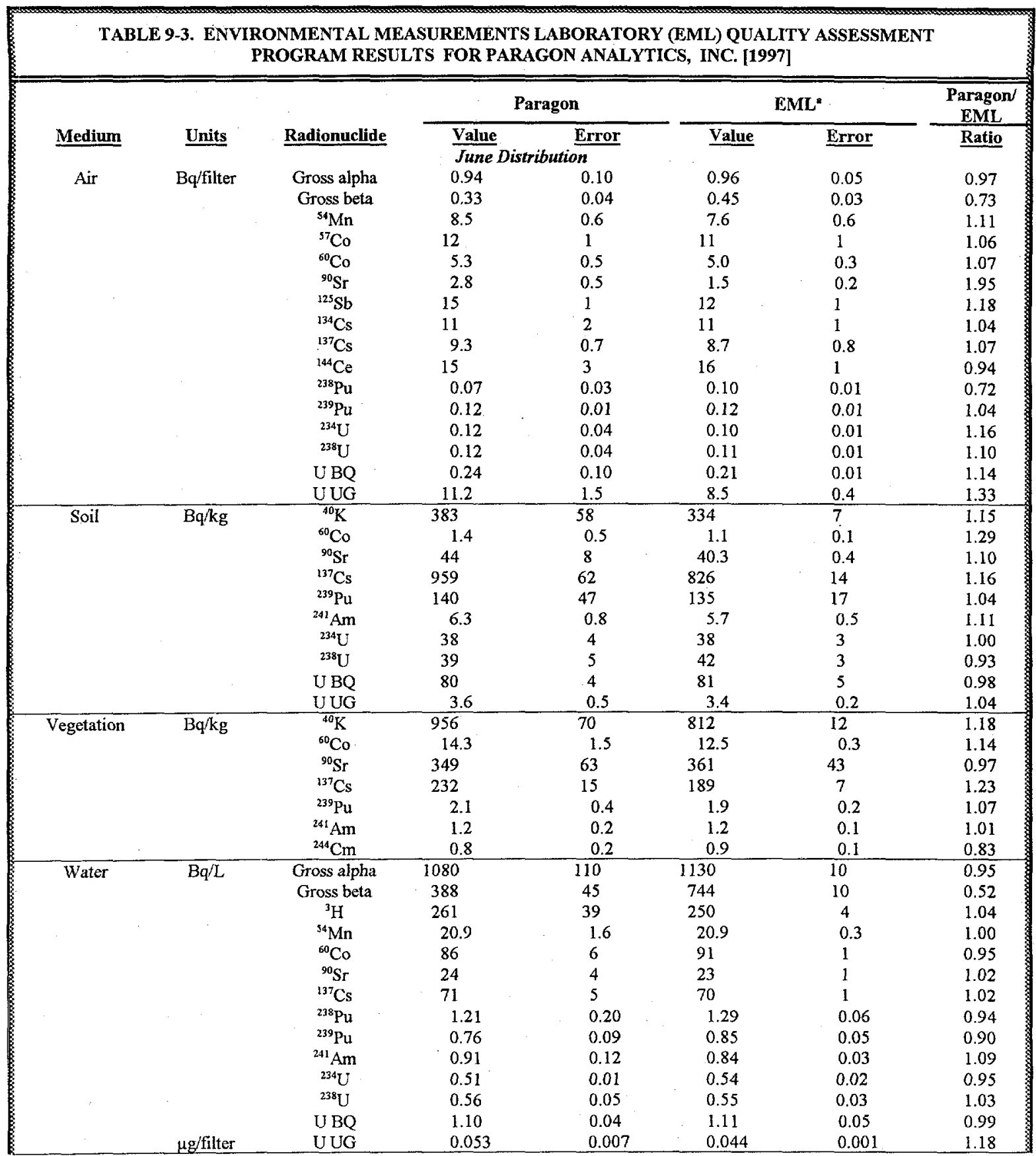




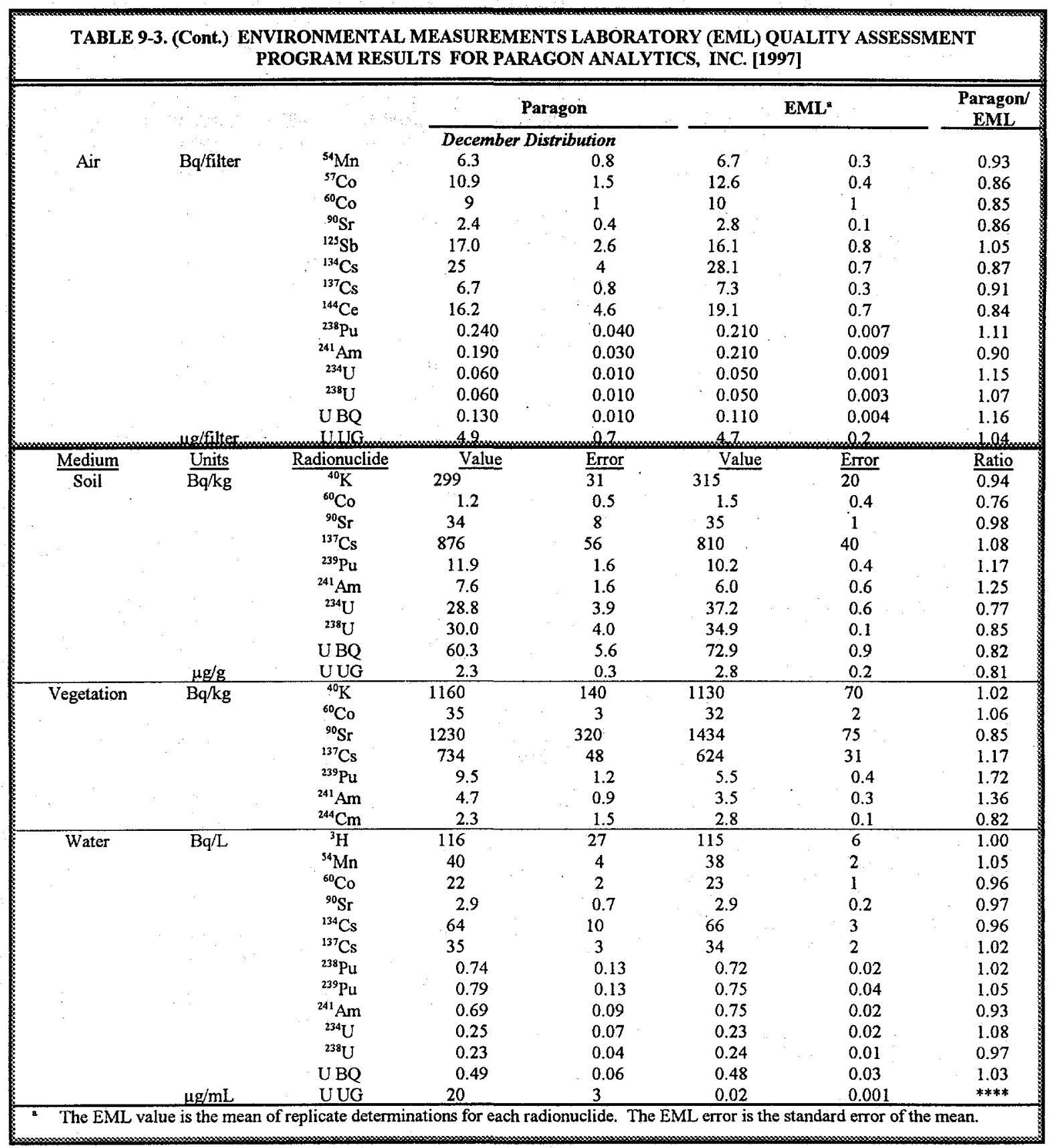




\begin{tabular}{|c|c|c|c|c|c|c|c|}
\hline TAB & 4. ENV & $\begin{array}{l}\text { NMENTAL M } \\
\text { PROGRAM }\end{array}$ & $\begin{array}{l}\text { UREMEN } \\
\text { SULTS F }\end{array}$ & $\begin{array}{l}\text { ORATO } \\
\text { NTERR }\end{array}$ & $\begin{array}{l}\text { EML) QU } \\
\text { C. [1997]. }\end{array}$ & ASSES & \\
\hline \multirow{2}{*}{ Medium } & \multirow[b]{2}{*}{ Units } & \multirow[b]{2}{*}{ Radionuclide } & \multicolumn{2}{|c|}{ Quanterra } & \multicolumn{2}{|c|}{$\mathbf{E M L}^{\mathbf{a}}$} & $\begin{array}{l}\text { Quanterra } \\
\text { EML }\end{array}$ \\
\hline & & & \multicolumn{2}{|c|}{ June Distribution } & Value & Error & Ratio \\
\hline \multirow[t]{14}{*}{ Air } & $\mathrm{Bq} /$ filter & Gross alpha & 1.02 & 0.03 & 0.96 & 0.05 & 1.06 \\
\hline & & Gross beta & 0.51 & 0.04 & 0.45 & 0.03 & 1.13 \\
\hline & & ${ }^{54} \mathrm{Mn}$ & 7.7 & 0.1 & 7.6 & 6 & 1.01 \\
\hline & & ${ }^{57} \mathrm{Co}$ & 10.6 & 0.2 & 10.8 & 1.0 & 0.98 \\
\hline & & ${ }^{60} \mathrm{Co}$ & 5.0 & 0.3 & 5.0 & 0.3 & 1.00 \\
\hline & & ${ }^{90} \mathrm{Sr}$ & 1.47 & 0.01 & 1.45 & 0.15 & 1.01 \\
\hline & & ${ }^{123} \mathrm{Sb}$ & 13.0 & 0.5 & 12.3 & 1.0 & 1.83 \\
\hline & & ${ }^{134} \mathrm{Cs}$ & 10.1 & 0.1 & 10.9 & 1.0 & 0.93 \\
\hline & & ${ }^{137} \mathrm{Cs}$ & 8.3 & 0.2 & 8.7 & 0.8 & 0.95 \\
\hline & & ${ }^{144} \mathrm{Ce}$ & 14.6 & 0.1 & 15.7 & 1.0 & 0.93 \\
\hline & & ${ }^{238} \mathrm{Pu}$ & 0.110 & 0.010 & 0.100 & 0.006 & 1.10 \\
\hline & & ${ }^{239} \mathrm{Pu}$ & 0.125 & 0.001 & 0.119 & 0.006 & 1.05 \\
\hline & & ${ }^{241} \mathrm{Am}$ & 0.14 & 0.01 & 0.15 & 0.01 & 0.92 \\
\hline & $\mu \mathrm{g} / \mathrm{filter}$ & UUG & 9.09 & 0.08 & 8.45 & 0.40 & 1.08 \\
\hline \multirow[t]{10}{*}{ Soil } & $\mathrm{Bq} / \mathrm{kg}$ & ${ }^{40} \mathrm{~K}$ & 375 & 3 & 334 & 7 & 1.12 \\
\hline & & ${ }^{60} \mathrm{Co}$ & 1.7 & 0.8 & 1.1 & 0.1 & 1.61 \\
\hline & & ${ }^{90} \mathrm{Sr}$ & 41 & 3 & 40.3 & 0.4 & 1.02 \\
\hline & & ${ }^{137} \mathrm{Cs}$ & 993 & 9 & 826 & 14 & 1.20 \\
\hline & & ${ }^{238} \mathrm{Pu}$ & 0.31 & 0.07 & 0.53 & 0.11 & 0.59 \\
\hline & & ${ }^{239} \mathrm{Pu}$ & 92 & 18 & 135 & 17 & 0.68 \\
\hline & & ${ }^{234} \mathrm{U}$ & 43 & 4 & 38 & 3 & 1.13 \\
\hline & & ${ }^{238} \mathrm{U}$ & 45 & 1 & 42 & 3 & 1.05 \\
\hline & & ${ }^{241} \mathrm{Am}$ & 5.9 & 0.3 & 5.7 & 0.5 & 1.05 \\
\hline & $\mu \mathrm{g} / \mathrm{g}$ & U UG & 3.32 & 0.04 & 3.43 & 0.2 & 0.97 \\
\hline \multirow[t]{7}{*}{ Vegetation } & $\mathrm{Bq} / \mathrm{kg}$ & ${ }^{40} \mathrm{~K}$ & 949 & 26 & 812 & 12 & 1.17 \\
\hline & & ${ }^{60} \mathrm{Co}$ & 15.0 & 0.6 & 12.5 & 0.3 & 1.20 \\
\hline & & ${ }^{90} \mathrm{Sr}$ & 395 & 9 & 361 & 43 & 1.09 \\
\hline & & ${ }^{137} \mathrm{Cs}$ & 228 & 3 & 189 & 7 & 1.20 \\
\hline & & ${ }^{239} \mathrm{Pu}$ & 2.0 & 0.2 & 1.9 & 0.2 & 1.05 \\
\hline & & ${ }^{241} \mathrm{Am}$ & 1.17 & 0.07 & 1.18 & 0.11 & 0.99 \\
\hline & & ${ }^{244} \mathrm{Cm}$ & 0.81 & 0.08 & 0.90 & 0.05 & 0.89 \\
\hline \multirow[t]{11}{*}{ Water } & $\mathrm{Bq} / \mathrm{L}$ & Gross alpha & 988 & 107 & 1130 & 10 & 0.87 \\
\hline & & Gross beta & 565 & 12 & 744 & 10 & 0.75 \\
\hline & & ${ }^{3} \mathrm{H}$ & 235 & 8 & 250 & 4 & 0.94 \\
\hline & & ${ }^{54} \mathrm{Mn}$ & 14.4 & 0.5 & 20.9 & 0.3 & 0.69 \\
\hline & & ${ }^{60} \mathrm{Co}$ & 165 & 2 & 91 & 1 & 1.82 \\
\hline & & ${ }^{90} \mathrm{Sr}$ & 24 & 1 & 23 & 1 & 1.05 \\
\hline & & ${ }^{137} \mathrm{Cs}$ & 74 & 3 & 70 & 1 & 1.06 \\
\hline & & ${ }^{238} \mathrm{Pu}$ & 1.33 & 0.07 & 1.29 & 0.06 & 1.03 \\
\hline & & ${ }^{239} \mathrm{Pu}$ & 0.83 & 0.05 & 0.85 & 0.05 & 0.98 \\
\hline & & ${ }^{241} \mathrm{Am}$ & 0.75 & 0.05 & 0.84 & 0.03 & 0.90 \\
\hline & $\mu \mathrm{g} / \mathrm{mL}$ & U UG & 0.049 & 0.011 & 0.044 & 0.001 & . $\quad 1.11$ \\
\hline
\end{tabular}




\begin{tabular}{|c|c|c|c|c|c|c|c|}
\hline \multirow[b]{2}{*}{ Medium } & \multirow[b]{2}{*}{ Units } & \multirow[b]{2}{*}{ Radionuclide } & \multicolumn{2}{|c|}{ Quanterra } & \multicolumn{2}{|c|}{ EML: } & \multirow{2}{*}{$\begin{array}{c}\begin{array}{c}\text { Quanterra } \\
\text { EML }\end{array} \\
\text { Ratio }\end{array}$} \\
\hline & & & \multicolumn{2}{|c|}{ December Distribution } & Value & Error & \\
\hline \multirow[t]{15}{*}{ Air } & $\mathrm{Bq} /$ filter & Gross alpha & 2.04 & 0.05 & 1.49 & 0.09 & 1.36 \\
\hline & & Gross beta & 3.53 & 0.01 & 3.00 & 0.14 & 1.17 \\
\hline & & ${ }^{54} \mathrm{Mn}$ & 6.5 & 0.2 & 6.7 & 0.3 & 0.97 \\
\hline & & ${ }^{57} \mathrm{Co}$ & 11.7 & 0.6 & 12.6 & 0.4 & 0.92 \\
\hline & & ${ }^{60} \mathrm{Co}$ & 9.6 & 0.4 & 10.7 & 1.1 & 0.89 \\
\hline & & ${ }^{90} \mathrm{Sr}$ & 3.0 & 0.6 & 2.8 & 0.1 & 1.08 \\
\hline & & ${ }^{125} \mathrm{Sb}$ & 7.5 & 0.2 & 16.1 & 0.8 & 0.46 \\
\hline & & ${ }^{134} \mathrm{Cs}$ & 24.1 & 0.9 & 28.2 & 0.7 & 0.85 \\
\hline & & ${ }^{137} \mathrm{Cs}$ & 6.6 & 0.1 & 7.3 & 0.3 & 0.90 \\
\hline & & ${ }^{238} \mathrm{Pu}$ & 0.24 & 0.01 & 0.21 & 0.01 & 1.11 \\
\hline & & ${ }^{239} \mathrm{Pu}$ & 0.120 & 0.010 & 0.100 & 0.004 & 1.16 \\
\hline & & ${ }^{241} \mathrm{Am}$ & 0.20 & 0.01 & 0.21 & 0.01 & 0.94 \\
\hline & & ${ }^{234} \mathrm{U}$ & 0.050 & 0.001 & $0.050^{\circ}$ & 0.001 & 1.03 \\
\hline & & ${ }^{238} \mathrm{U}$ & 0.060 & 0.006 & 0.050 & 0.003 & 1.12 \\
\hline & $\mu g /$ filter & UUG & 4.70 & 0.02 & 4.65 & 0.21 & 1.01 \\
\hline \multirow[t]{10}{*}{ Soil } & $\mathrm{Bq} / \mathrm{kg}$ & ${ }^{40} \mathrm{~K}$ & 332 & 7 & 315 & 20 & 1.05 \\
\hline & & ${ }^{60} \mathrm{Co}$ & 1.5 & 0.6 & 1.5 & 0.4 & 1.02 \\
\hline & & ${ }^{90} \mathrm{Sr}$ & 37.3 & 0.8 & 34.8 & $1: 0$ & 1.07 \\
\hline & & ${ }^{137} \mathrm{Cs}$ & 903 & 2 & 810 & 40 & 1.11 \\
\hline & & ${ }^{238} \mathrm{Pu}$ & 0.44 & 0.07 & 0.44 & 0.09 & 1.00 \\
\hline & & ${ }^{239} \mathrm{Pu}$ & 10.9 & 0.3 & 10.2 & 0.4 & 1.06 \\
\hline & & ${ }^{241} \mathrm{Am}$ & 6.0 & 0.1 & 6.0 & 0.6 & 0.99 \\
\hline & & ${ }^{234} \mathrm{U}$ & 35.8 & 1.1 & 37.2 & 0.6 & 0.96 \\
\hline & & ${ }^{238} \mathrm{U}$ & 33.8 & 0.5 & 34.9 & 0.1 & 0.96 \\
\hline & $\mu \mathrm{g} / \mathrm{g}$ & U UG & 2.72 & 0.06 & 2.82 & 0.20 & 0.96 \\
\hline \multirow[t]{7}{*}{ Vegetation } & $\mathrm{Bq} / \mathrm{kg}$ & ${ }^{40} \mathrm{~K}$ & 1120 & 82 & 1130 & 70 & 0.99 \\
\hline & & ${ }^{60} \mathrm{Co}$ & 36 & 2 & 32 & 2 & 1.11 \\
\hline & & ${ }^{90} \mathrm{Sr}$ & 1405 & 63 & 1434 & 75 & 0.97 \\
\hline & & ${ }^{137} \mathrm{Cs}$ & 617 & 33 & 624 & 31 & 0.98 \\
\hline & & ${ }^{239} \mathrm{Pu}$ & 6.5 & 0.5 & 5.5 & 0.4 & 1.18 \\
\hline & & ${ }^{241} \mathrm{Am}$ & 3.8 & 0.2 & 3.5 & 0.3 & 1.10 \\
\hline & & ${ }^{244} \mathrm{Cm}$ & 2.28 & 0.02 & 2.75 & 0.10 & 0.82 \\
\hline \multirow[t]{14}{*}{ Water } & $\mathrm{Bq} / \mathrm{L}$ & Gross alpha & 576 & 67 & 557 & 60 & 1.03 \\
\hline & & Gross beta & 754 & 22 & 712 & 70 & 1.05 \\
\hline & & ${ }^{3} \mathrm{H}$ & 127 & 9 & 115 & 6 & 1.10 \\
\hline & & ${ }^{54} \mathrm{Mn}$ & 40 & 1 & 39 & 2 & 1.05 \\
\hline & & ${ }^{60} \mathrm{Co}$ & 23 & 1 & 23 & 1 & 0.99 \\
\hline & & ${ }^{90} \mathrm{Sr}$ & 3.0 & 0.2 & 2.9 & 0.2 & 1.02 \\
\hline & & ${ }^{194} \mathrm{Cs}$ & 67 & 2 & 66 & 3 & 1.00 \\
\hline & & ${ }^{137} \mathrm{Cs}$ & 34 & 3 & 34 & 2 & 1.00 \\
\hline & & ${ }^{238} \mathrm{Pu}$ & 0.71 & 0.02 & 0.72 & 0.02 & 0.98 \\
\hline & & ${ }^{239} \mathrm{Pu}$ & 0.77 & 0.05 & 0.75 & 0.04 & 1.02 \\
\hline & & ${ }^{241} \mathrm{Am}$ & 0.71 & 0.02 & 0.75 & 0.02 & 0.94 \\
\hline & & ${ }^{234} \mathrm{U}$ & 0.25 & 0.02 & 0.23 & 0.02 & 1.08 \\
\hline & & ${ }^{238} \mathrm{U}$ & 0.27 & 0.02 & 0.24 & 0.01 & 1.12 \\
\hline & & UUG & 0.020 & 0.000 & 0.020 & 0.001 & 1.03 \\
\hline
\end{tabular}

that are analyzed separately), and spike samples (samples to which a known amount of a contaminant is added).

Both the Foundation and LMITCO maintained duplicate air samplers at two locations during 1997 (Table 9-5). The Foundation operated these samplers at Monteview and the FAA
Tower and the LMITCO samplers were at the Central Facilities Area (CFA) and Test Area North (TAN). Filters from these samplers were collected and analyzed in the same manner as filters from regular air samplers. 


\begin{tabular}{|c|c|c|c|c|c|c|c|c|}
\hline \multicolumn{9}{|c|}{$\begin{array}{r}\text { TABLE 9-5. COMPARISON OF DUPLICATE AIR MONITORING R } \\
\text { Environmental Science and Research Foundation Data }\end{array}$} \\
\hline & \multicolumn{4}{|c|}{ Gross Alpha $\left(10^{-15} \mu \mathrm{Ci} / \mathrm{mL}\right)^{a}$} & \multicolumn{4}{|c|}{ Gross Beta $\left(10^{-15} \mu \mathrm{Ci} / \mathrm{mL}\right)^{a}$} \\
\hline & \multicolumn{2}{|c|}{ Monteview } & \multicolumn{2}{|c|}{ FAA Tower } & \multicolumn{2}{|c|}{ Monteview } & \multicolumn{2}{|c|}{ FAA Tower } \\
\hline Mionth & Sampler & Duplicate & Sampler & Duplicate & Sampler & Duplicate & Sampler & Duplicate \\
\hline January & $2.9 \pm 3.5$ & $2.7 \pm 2.0$ & $1.7 \pm 2.9$ & $3.3 \pm 0.4$ & $28 \pm 23$ & $24 \pm 12$ & $21 \pm 24$ & $24 \pm 21$ \\
\hline February & $2.5 \pm 2.7$ & $2.5 \pm 1.8$ & $2.1 \pm 2.0$ & $2.0 \pm 1.5$ & $21 \pm 19$ & $19 \pm 8$ & $18 \pm 18$ & $18 \pm 10$ \\
\hline March & $2.5 \pm 0.5$ & $2.1 \pm 0.4$ & $2.1 \pm 1.0$ & $1.7 \pm 0.4$ & $16 \pm 5$ & $14 \pm 4$ & $15 \pm 5$ & $14 \pm 4$ \\
\hline April & $2.8 \pm 1.2$ & $2.0 \pm 1.4$ & $2.0 \pm 2.1$ & $2.4 \pm 1.0$ & $20 \pm 9$ & $18 \pm 6$ & $18 \pm 11$ & $17 \pm 6$ \\
\hline May & $1.5 \pm 0.9$ & $1.7 \pm 0.5$ & $1.9 \pm 1.2$ & $1.8 \pm 0.7$ & $26 \pm 12$ & $24 \pm 6$ & $24 \pm 8$ & $23 \pm 6$ \\
\hline June & $0.9 \pm 0.2$ & $0.9 \pm 0.4$ & $1.0 \pm 0.2$ & $0.7 \pm 0.6$ & $23 \pm 4$ & $21 \pm 4$ & $19 \pm 6$ & $20 \pm 4$ \\
\hline July & $1.4 \pm 0.9$ & $1.3 \pm 0.5$ & $1.0 \pm 0.1$ & $1.0 \pm 0.2$ & $29 \pm 7$ & $30 \pm 5$ & $24 \pm 8$ & $24 \pm 5$ \\
\hline August & $1.3 \pm 0.5$ & $1.3 \pm 0.5$ & $1.2 \pm 0.8$ & $1.3 \pm 0.4$ & $26 \pm 6$ & $29 \pm 4$ & $23 \pm 4$ & $26 \pm 5$ \\
\hline September & $1.8 \pm 0.8$ & $1.2 \pm 0.5$ & $1.1 \pm 0.8$ & $0.7 \pm 0.5$ & $29 \pm 8$ & $25 \pm 5$ & $21 \pm 8$ & $22 \pm 3$ \\
\hline October & $1.4 \pm 0.9$ & $1.5 \pm 0.4$ & $1.8 \pm 3.2$ & $1.0 \pm 0.6$ & $29 \pm 15$ & $31 \pm 13$ & $36 \pm 42$ & $26 \pm 10$ \\
\hline November & $2.2 \pm 1.1$ & $1.8 \pm 0.4$ & $1.3 \pm 0.8$ & $1.1 \pm 0.5$ & $33 \pm 21$ & $35 \pm 10$ & $24 \pm 14$ & $25 \pm 11$ \\
\hline December & $1.3 \pm 0.4$ & $1.8 \pm 0.4$ & $0.6 \pm 0.4$ & $0.5 \pm 0.3$ & $30 \pm 7$ & $32 \pm 4$ & $18 \pm 5$ & $25 \pm 2$ \\
\hline Annual & $1.9 \pm 0.4$ & $1.7 \pm 0.3$ & $1.5 \pm 0.3$ & $1.5 \pm 0.5$ & $26 \pm 3$ & $25 \pm 4$ & $22 \pm 3$ & $22 \pm 3$ \\
\hline \multicolumn{9}{|c|}{ LMITCO Data } \\
\hline & \multicolumn{4}{|c|}{ Gross Alpha $\left(10^{-15} \mu \mathrm{Ci} / \mathrm{mL}\right)^{\mathrm{a}}$} & \multicolumn{4}{|c|}{ Gross Beta $\left(10^{-15} \mu \mathrm{Ci} / \mathrm{mL}\right)^{\mathrm{a}}$} \\
\hline & \multicolumn{2}{|c|}{ CFA } & \multicolumn{2}{|c|}{ TAN } & \multicolumn{2}{|c|}{ CFA } & \multicolumn{2}{|c|}{$\mathbf{T A N}$} \\
\hline Month & Sampler & Duplicate & Sampler & Duplicate & Sampler & Duplicate & Sampler & Duplicate \\
\hline January & $0.4 \pm 0.7$ & $0.5 \pm 1.0$ & $0.5 \pm 0.7$ & $0.5 \pm 0.6$ & $16 \pm 9$ & $22 \pm 14$ & $19 \pm 12$ & $20 \pm 10$ \\
\hline February & $-0.0 \pm 0.9$ & $0.3 \pm 0.7$ & $0.4 \pm 1.0$ & $0.1 \pm 0.9$ & $15 \pm 7$ & $19 \pm 14$ & $20 \pm 12$ & $19 \pm 13$ \\
\hline March & $-0.2 \pm 0.5$ & $0.1 \pm 0.9$ & $1.1 \pm 0.4$ & $0.7 \pm 0.8$ & $10 \pm 6$ & $13 \pm 7$ & $15 \pm 4$ & $17 \pm 4$ \\
\hline April & $0.8 \pm 0.3$ & $0.3 \pm 0.3$ & $1.1 \pm 0.5$ & $0.5 \pm 0.6$ & $16 \pm 5$ & $15 \pm 2$ & $16 \pm 2$ & $16 \pm 1$ \\
\hline $\mathrm{May}$ & $1.0 \pm 0.8$ & $0.7 \pm 1.0$ & $1.6 \pm 0.3$ & $1.3 \pm 0.4$ & $18 \pm 6$ & $21 \pm 8$ & $20 \pm 5$ & $19 \pm 4$ \\
\hline June & $0.8 \pm 0.8$ & $1.0 \pm 0.8$ & $0.8 \pm 0.3$ & $0.5 \pm 0.7$ & $16 \pm 4$ & $22 \pm 2$ & $19 \pm 1$ & $18 \pm 3$ \\
\hline July & $0.5 \pm 0.8$ & $1.1 \pm 1.0$ & $1.0 \pm 0.5$ & $0.4 \pm 0.5$ & $22 \pm 6$ & $15 \pm 4$ & $23 \pm 5$ & $21 \pm 4$ \\
\hline August & $0.9 \pm 0.3$ & $0.7 \pm 0.5$ & $1.5 \pm 0.7$ & $1.0 \pm 0.4$ & $22 \pm 6$ & $23 \pm 1$ & $24 \pm 2$ & $23 \pm 6$ \\
\hline September & $0.5 \pm 0.9$ & $1.1 \pm 1.3$ & $1.0 \pm 1.0$ & $1.3 \pm 0.3$ & $17 \pm 5$ & $22 \pm 5$ & $18 \pm 5$ & $20 \pm 5$ \\
\hline October & $0.9 \pm 1.3$ & $2.1 \pm 1.1$ & $1.2 \pm 0.4$ & $1.3 \pm 0.8$ & $24 \pm 10$ & $25 \pm 12$ & $23 \pm 9$ & $26 \pm 9$ \\
\hline November & $0.7 \pm 0.7$ & $0.9 \pm 0.9$ & $1.5 \pm 0.8$ & $1.2 \pm 0.5$ & $28 \pm 11$ & $27 \pm 11$ & $22 \pm 6$ & $26 \pm 11$ \\
\hline December & $1.1 \pm 0.6$ & $0.7 \pm 0.8$ & $-0.1 \pm 0.2$ & $0.4 \pm 0.3$ & $26 \pm 3$ & $24 \pm 5$ & $27 \pm 5$ & $28 \pm 5$ \\
\hline Annual & $0.6 \pm 0.3$ & $0.8 \pm 0.3$ & $1.0 \pm 0.3$ & $0.8 \pm 0.3$ & $19 \pm 3$ & $21 \pm 3$ & $21 \pm 2$ & $21 \pm 2$ \\
\hline
\end{tabular}

\section{Duplicate Data Comparisons}

Another measure of data quality can be made by comparing data collected simultaneously by different organizations. The Foundation, LMITCO, and the state of Idaho collected air monitoring data throughout 1997 in conjunction with the INEEL at three sampling locations, the distant location of Craters of the Moon and on the INEEL at the Experimental Field Station (EFS) and Van Buren Avenue. Data from these three sampling locations for gross alpha and gross beta are shown in Tables 9-6 and 9-7.
The Foundation also collects quarterly samples of drinking and surface water jointly with the State Oversight Program at five locations in the Magic Valley area. Table 9-8 contains results from analysis of 1997 samples from these locations. Also, the USGS collects groundwater samples simultaneously with the state of Idaho. 


\begin{tabular}{|c|c|c|c|c|c|c|c|c|c|}
\hline \multicolumn{10}{|c|}{$\begin{array}{l}\text { TABLE 9-6. COMPARISON OF FOUNDATION (F), LMITCO (L) AND STATE OF IDAHO (S) } \\
\text { AIR MONITORING RESULTS-GROSS ALPHA (1997) }\end{array}$} \\
\hline \multirow{3}{*}{$\begin{array}{l}\text { Week } \\
\text { Ending }\end{array}$} & \multicolumn{9}{|c|}{ Gross Alpha $\left(10^{-15} \mu \mathrm{Ci} / \mathrm{mL}\right)^{2}$} \\
\hline & \multicolumn{3}{|c|}{ Craters of the Moon } & \multicolumn{3}{|c|}{ EFS } & \multicolumn{3}{|c|}{ Van Buren } \\
\hline & $\overline{\mathbf{F}}$ & $\bar{L}$ & $\overline{\mathbf{S}}$ & $\overline{\mathbf{F}}$ & $\mathrm{L}$ & $\mathbf{S}$ & $\bar{F}$ & $\overline{\mathrm{L}}$ & $\overline{\mathbf{S}}$ \\
\hline $1 / 8$ & $0.4 \pm 0.6$ & $-0.2 \pm 1.4$ & $1.5 \pm 0.8$ & $0.8 \pm 0.7$ & $\mathrm{NS}^{\mathrm{b}}$ & $2.2 \pm 1.2$ & $0.7 \pm 0.6$ & $0.5 \pm 2.0$ & $1.5 \pm 0.7$ \\
\hline $1 / 15$ & $1.6 \pm 0.7$ & $1.4 \pm 1.6$ & NS & $2.1 \pm 0.8$ & $1.5 \pm 1.8$ & $2.1 \pm 0.8$ & $1.8 \pm 0.8$ & $0.9 \pm 2.0$ & $1.3+0.7$ \\
\hline $1 / 22$ & $6.1 \pm 1.2$ & $-0.1+1.2$ & $1.8 \pm 0.8$ & $6.0 \pm 1.3$ & $0.4 \pm 1.4$ & $1.5 \pm 0.8$ & $4.8 \pm 1.1$ & $0.5 \pm 1.8$ & $1.9 \pm 0.8$ \\
\hline $1 / 29$ & $1.5 \pm 0.7$ & $-1.1 \pm 1.2$ & $3.4 \pm 1.0$ & $2.6 \pm 0.9$ & $1.9 \pm 1.6$ & $1.5 \pm 0.8$ & $1.9 \pm 0.7$ & $-0.2+1.8$ & $3.4 \pm 1.0$ \\
\hline $2 / 5$ & $1.2+0.6$ & $1.3+1.4$ & $0.8+0.6$ & $1.9+0.8$ & $-0.3+1.2$ & $0.5+0.6$ & $1.5+0.7$ & $-0 . \overline{-1}+1.8$ & $\overline{0.6+0.6}$ \\
\hline $2 / 12$ & $5.0+1.1$ & $-0.5+1.4$ & $2.6+0.9$ & $4.7+1.2$ & $1.9+1.8$ & $3.4+1.5$ & $4.0+1.1$ & $0.8+2.0$ & $2.4+0.9$ \\
\hline $2 / 19$ & $1.3+0.6$ & $\overline{0.3+1.4}$ & $0.9 \overline{+0.6}$ & $3.0+0.9$ & $0.8+1.6$ & $1.4+0.9$ & $1.5+0.7$ & $-0.8+1.8$ & $0.5+0.5$ \\
\hline $2 / 26$ & $1.7 \pm 0.7$ & $0.9 \pm 1.4$ & $0.6 \pm 0.5$ & $1.5 \pm 0.8$ & $-0.4 \pm 1.2$ & $0.9 \pm 0.8$ & $1.2 \pm 0.7$ & $-0.3 \pm 1.4$ & $0.9+0.6$ \\
\hline $3 / 5$ & $1.4 \pm 0.7$ & $0.0 \pm 1.6$ & $1.2 \pm 0.7$ & $1.2 \pm 0.7$ & $0.0 \pm 1.4$ & NS & $1.5+0.7$ & $-1.1+2.0$ & $0.4 \pm 0.5$ \\
\hline $3 / 12$ & $2.3+0.8$ & $-0.6 \pm 1.6$ & $3.5 \pm 1.0$ & $3.0 \pm 1.0$ & $0.2 \pm 1.4$ & $1.1 \pm 0.6$ & $3.0+0.9$ & $-0.7+2.0$ & $1.1 \pm 0.7$ \\
\hline $3 / 19$ & $2.0 \pm 0.7$ & $0.2 \pm 1.2$ & $3.4 \pm 1.0$ & $2.2 \pm 0.9$ & $\overline{\mathrm{NS}}$ & $1.5 \pm 0.7$ & $2.2 \pm 0.9$ & $0.6+1.8$ & $0.7 \pm 0.6$ \\
\hline $3 / 26$ & $2.5 \pm 0.8$ & $0.0 \pm 1.4$ & $1.3 \pm 0.7$ & $3.5 \pm 1.0$ & $2.9 \pm 2.0$ & $0.4+0.5$ & $3.3+1.1$ & $1.0 \overline{+2.0}$ & $0.5+0.5$ \\
\hline $4 / 2$ & $1.6 \pm 0.7$ & $0.0 \pm 1.4$ & $1.4 \pm 0.7$ & $2.0 \pm 0.8$ & $-0.4+1.8$ & $1.9 \pm 0.8$ & $2.0 \pm 0.8$ & $0.5 \pm 2.2$ & $1.1 \pm 0.6$ \\
\hline $4 / 9$ & $0.7 \pm 0.8$ & $0.9 \pm 1.6$ & $0.9 \pm 0.7$ & $1.3 \pm 1.2$ & $1.3 \pm 2.2$ & $2.1 \pm 0.9$ & $1.2 \pm 0.9$ & $\mathrm{NS}$ & $1.9 \pm 0.9$ \\
\hline $4 / 16$ & $\overline{\mathrm{NS}}$ & $0.8 \pm 1.6$ & $1.0 \pm 0.7$ & $4.0 \pm 1.5$ & $1.7 \pm 2.0$ & $1.6 \pm 0.8$ & $3.8+1.4$ & NS & $2.4 \pm 1.0$ \\
\hline $4 / 23$ & $1.6 \pm 1.0$ & $-0.6 \pm 1.6$ & $0.6 \pm 0.6$ & $2.4 \pm 1.2$ & $0.5 \pm 2.0$ & $1.2 \pm 0.8$ & $3.0 \pm 1.2$ & $-0.3 \pm 2.4$ & $1.4 \pm 0.8$ \\
\hline $4 / 30$ & $0.4 \pm 0.7$ & $0.5 \pm 1.4$ & $1.4 \pm 0.8$ & $2.5 \pm 1.1$ & $-0.1 \pm 1.8$ & $0.9 \pm 0.7$ & $0.8 \pm 0.9$ & $-0.1+2.0$ & $1.0+0.7$ \\
\hline $5 / 7$ & $2.2 \pm 1.0$ & $0.3 \pm 1.4$ & $1.7 \pm 0.9$ & $2.0 \pm 1.2$ & $2.7 \pm 2.0$ & $1.8 \pm 1.0$ & $2.2 \pm 1.2$ & $1.3 \pm 2.0$ & $2.5 \pm 1.0$ \\
\hline $5 / 14$ & $1.2 \pm 0.7$ & $1.2 \pm 1.6$ & $2.2 \pm 1.0$ & $3.6 \pm 1.1$ & $0.6 \pm 1.6$ & $4.0 \pm 1.2$ & $3.2 \pm 1.0$ & $1.7 \pm 2.0$ & $3.2 \pm 1.1$ \\
\hline $5 / 21$ & $1.3 \pm 0.8$ & $1.1 \pm 1.6$ & $1.8 \pm 0.9$ & $0.6 \pm 0.8$ & $\overline{\mathrm{NS}}$ & $1.9 \pm 0.9$ & $0.9 \pm 0.7$ & $1.0 \pm 1.8$ & $2.4 \pm 1.5$ \\
\hline $5 / 28$ & $0.8 \pm 0.6$ & $0.9 \pm 1.2$ & $2.3 \pm 0.1$ & $1.6 \pm 0.8$ & $1.4 \pm 1.6$ & $2.1 \pm 0.9$ & $1.1 \pm 0.7$ & $1.8 \pm 2.0$ & $1.5 \pm 0.8$ \\
\hline $6 / 4$ & $0.6+0.6$ & $1.1+1.2$ & $2.4+1.0$ & $0.6 \pm 0.7$ & $1.6 \pm 1.6$ & $3.1+1.1$ & $0.8+0.7$ & $1.0+1.8$ & $4.0+1.3$ \\
\hline $6 / 11$ & $0.8+0.6$ & $0.1+1.0$ & $1.6+0.8$ & $0.9 \pm 0.7$ & $0.2+1.4$ & $2.3+1.0$ & $1.2+0.7$ & $-1.0+1.4$ & $1.6+0.9$ \\
\hline $6 / 18$ & $0.8+0.6$ & $0.7+1.2$ & $1.1+0.8$ & $1.2+0.7$ & $1.3+1.6$ & NS & $0 . \overline{0+0.6}$ & $1.5+1.8$ & $1.2+0.8$ \\
\hline $6 / 25$ & $0.5 \pm 0.6$ & $0.4 \pm 1.0$ & $2.2 \pm 1.0$ & $1.5 \pm 0.8$ & $1.3 \pm 1.6$ & $2.2 \pm 1.1$ & $1.1 \pm 0.7$ & $1.4+2.0$ & $1.9+1.0$ \\
\hline $7 / 2$ & $0.7 \pm 0.6$ & $0.8 \pm 1.2$ & $2.6 \pm 1.0$ & $1.6 \pm 0.8$ & $0.0 \pm 1.2$ & $\overline{\mathrm{NS}}$ & $1.8 \pm 0.8$ & $3.5 \pm 2.2$ & $3.3 \pm 1.1$ \\
\hline $7 / 9$ & $1.1+0.7$ & $0.6 \pm 1.2$ & $1.5+0.9$ & $1.0 \pm 0.8$ & $2.8 \pm 1.8$ & $1.1 \pm 1.0$ & $1.2+0.7$ & $1.9+1.8$ & $2.5+1.1$ \\
\hline $7 / 16$ & $0.5 \pm 0.6$ & $0.9 \pm 1.2$ & $1.6 \pm 0.9$ & $0.8 \pm 0.8$ & $1.2 \pm 1.6$ & $4.5 \pm 1.8$ & $1.3 \pm 0.7$ & $2.1 \pm 2.0$ & $2.6 \pm 1.1$ \\
\hline $7 / 23$ & $1.0 \pm 0.7$ & $1.2 \pm 1.2$ & $0.5 \pm 0.7$ & $1.3 \pm 0.8$ & $1.3 \pm 1.6$ & $2.1 \pm 1.0$ & $1.2 \pm 0.7$ & $0.8 \pm 1.8$ & $1.5 \pm 0.9$ \\
\hline $7 / 30$ & $1.4 \pm 0.7$ & $0.3 \pm 1.0$ & $1.3 \pm 0.9$ & $1.2 \pm 0.8$ & $-0.2 \pm 1.4$ & NS & $1.0 \pm 0.7$ & $2.1 \pm 2.0$ & $1.3+0.9$ \\
\hline $8 / 6$ & $0.1 \pm 0.9$ & $0.3+1.0$ & $2.0+1.0$ & $0.8 \pm 0 . \overline{9}$ & $2.0 \pm 1.6$ & $\mathrm{NS}$ & $0.5+0.7$ & $1.0+1.6$ & $2.3+1.0$ \\
\hline $8 / 13$ & $1.3+0.6$ & $1.0+1.2$ & $2.4+1.1$ & $1.4 \pm 0.8$ & $1.1 \pm 1.8$ & NS & $1.5+0.7$ & $1.2+2.0$ & $2.3+1.1$ \\
\hline $8 / 20$ & $1.3+0.8$ & $\overline{0.6+1.0}$ & $1.4+0.9$ & $1.2+0.8$ & $1.0+1.6$ & $2.0+1.0$ & $1.2+0.8$ & $0.2+1.0$ & $2.3+1.0$ \\
\hline $8 / 27$ & $1 . \overline{0.8}$ & $1.1+1.2$ & $1.7+0.9$ & $0.7+0.9$ & $0.6+1.4$ & $1 . \overline{2+0.9}$ & $1.4+0.8$ & $1.8+1.8$ & $1 . \overline{5+0.9}$ \\
\hline $9 / 3$ & $2.4 \pm 0.9$ & $0.4 \pm 1.0$ & $2.0 \pm 1.0$ & $2.7 \pm 1.1$ & $1.5 \pm 1.8$ & $\overline{\mathrm{NS}}$ & $1.4 \pm 0.8$ & $1.0 \pm 1.6$ & $2.2 \pm 1.0$ \\
\hline $9 / 10$ & $1.1 \pm 0.9$ & $0.5 \pm 1.0$ & $0.3 \pm 0.7$ & $0.3 \pm 1.4$ & $1.0 \pm 1.4$ & $1.3 \pm 0.9$ & $1.4 \pm 0.9$ & $1.1 \pm 1.6$ & $0 . \overline{9} \pm 0.8$ \\
\hline $9 / 17$ & $0.6 \pm 0.6$ & $0.9 \pm 1.2$ & $0.9 \pm 0.8$ & $\overline{\mathrm{NS}}$ & $0.4 \pm 1.4$ & $1.1 \pm 0.8$ & $1.4 \pm 0.8$ & $1.6 \pm 1.8$ & $0.9 \pm 0.8$ \\
\hline $9 / 24$ & $0.8 \pm 0.6$ & $0.3 \pm 1.2$ & $0.8 \pm 0.8$ & $1.2 \pm 1.0$ & $-2.0 \pm 1.4$ & $4.9 \pm 1.4$ & $1.3 \pm 0.7$ & $1.0 \pm 2.0$ & $2.5 \pm 1.1$ \\
\hline $10 / 1$ & $1.8+0.8$ & $0.0 \pm 1.2$ & $1.8+0.9$ & $2.0 \pm 1.1$ & $1.2+1.6$ & $2.1+1.0$ & $3.5+1.0$ & $0.4+2.0$ & $0.9+0.9$ \\
\hline $10 / 8$ & $0.4+0.7$ & $0.0+1.0$ & $1.5+0.9$ & $0.3 \pm 0.9$ & $0.2+2.0$ & $1.8+1.0$ & $0.9+0.7$ & $1.0+1.8$ & $1.5+0.2$ \\
\hline $10 / 15$ & $0.8+0.7$ & $0.6+1.2$ & $1.4+0.9$ & $0.6+0.6$ & $0.7+1.4$ & $2.5+1.1$ & $0.9+0.8$ & $1.8+1.8$ & $\overline{\mathrm{NS}}$ \\
\hline $10 / 22$ & $1.3 \pm 1.0$ & $2.0 \pm 1.8$ & $2.0 \pm 1.0$ & $2.6 \pm 1.2$ & $0.5 \pm 1.4$ & $1.8 \pm 1.0$ & $2.5 \pm 1.1$ & $1.1+2.0$ & $4.1+1.4$ \\
\hline $10 / 29$ & $1.0 \pm 0.8$ & $0.8 \pm 1.6$ & $1.1 \pm 0.8$ & $1.6 \pm 0.9$ & $2.5 \pm 1.8$ & $1.3 \pm 0.9$ & $1.6 \pm 1.0$ & $2.3+2.4$ & $1.5+0.9$ \\
\hline $11 / 5$ & $1.1 \pm 0.7$ & $0.7 \pm 1.4$ & $1.1 \pm 0.8$ & $1.9 \pm 0.8$ & $1.6 \pm 1.6$ & $\overline{\mathrm{NS}}$ & $2.6 \pm 0.9$ & $2.3 \pm 2.0$ & $0.6 \pm 0.7$ \\
\hline $11 / 12$ & $1.3 \pm 0.9$ & $0.3 \pm 1.2$ & $1.6 \pm 0.9$ & $1.2 \pm 0.7$ & $1.3 \pm 1.6$ & $2.3 \pm 1.0$ & $1.5 \pm 0.9$ & $0.9 \pm 1.8$ & $1.7 \pm 1.0$ \\
\hline $11 / 19$ & $2.3 \pm 0.9$ & $0.4 \pm 1.6$ & $1.1 \pm 0.5$ & $3.9 \pm 1.1$ & $1.7 \pm 1.8$ & $1.9 \pm 0.6$ & $3.4 \pm 1.1$ & $0.2 \pm 1.8$ & $1.2 \pm 0.5$ \\
\hline $11 / 25$ & $0.6+0.6$ & $-0.1+1.2$ & $0.4+0.5$ & $1.2 \pm 0.6$ & $0.4 \pm 1.4$ & $0.2 \pm 0.3$ & $1.5 \pm 0.8$ & $-0.3+1.8$ & $0.6+0.5$ \\
\hline $12 / 3$ & $1.1 \pm 0.7$ & $0.3 \pm 1.4$ & $0.9 \pm 0.4$ & $0.8+0.6$ & $1.3+1.6$ & $0 . \overline{7 \pm 0.5}$ & $1.1+0.7$ & $-0.6+1.6$ & $\overline{0.5+0.4}$ \\
\hline $12 / 10$ & $1.0 \pm 0.6$ & $-0 . \overline{2}+1.4$ & $\overline{\mathrm{NS}}$ & $1.0 \pm 0.5$ & $-0.5 \pm 1.4$ & $1.4+0.6$ & $1.0+0.6$ & $0.4+2.2$ & $0.7+0.5$ \\
\hline $12 / 17$ & $1.1+0.6$ & $0.9+1.6$ & $\overline{N S}$ & $1.1+0.6$ & $-0.1+1.6$ & $1.0+0.5$ & $1 . \overline{2+0.7}$ & $1.7+2.4$ & $0.6+0.4$ \\
\hline $12 / 23$ & $1.1+0.6$ & $0.0+1.4$ & $0.6+0.5$ & $0.6+0.5$ & $0.3+1.6$ & $0.6+0.5$ & $0.3+0.5$ & $-0.1+2.0$ & $0 . \overline{9+0.5}$ \\
\hline $12 / 31$ & $0.7+0.5$ & $0 . \overline{1+0.8}$ & $0.5+0.4$ & $0.7+0.5$ & $0.3+0.8$ & $0.7+0.4$ & $0.8+0.5$ & $0.2+1.0$ & $0.5+0.4$ \\
\hline
\end{tabular}




\begin{tabular}{|c|c|c|c|c|c|c|c|c|c|}
\hline \multirow{4}{*}{$\begin{array}{c}\text { Week } \\
\text { Ending }\end{array}$} & \multicolumn{9}{|c|}{ AIR MONITORING RESULTS_-GROSS BETA (1997) } \\
\hline & \multicolumn{9}{|c|}{ Gross Beta $\left(10^{-15} \mu \mathrm{Ci} / \mathrm{mL}\right)^{2}$} \\
\hline & \multicolumn{3}{|c|}{ Craters of the Moon } & \multicolumn{3}{|c|}{ EFS } & \multicolumn{3}{|c|}{ Van Buren } \\
\hline & $\mathbf{F}$ & $\mathbf{L}$ & $\mathbf{S}$ & $\mathbf{F}$ & $\mathbf{L}$ & $\mathbf{S}$ & $\mathbf{F}$ & $\mathbf{L}$ & $\overline{\mathbf{S}}$ \\
\hline $1 / 8$ & $9 \pm 1$ & $14 \pm 3$ & $18 \pm 3$ & $9 \pm 1$ & $\mathrm{NS}^{\circ}$ & $22 \pm 5$ & $11+1$ & $16 \pm 4$ & $22 \pm 3$ \\
\hline $1 / 15$ & $22 \pm 2$ & $20 \pm 3$ & NS & $32 \pm 2$ & $27 \pm 4$ & $38 \pm 4$ & $27 \pm 2$ & $20 \pm 4$ & $\overline{36 \pm 4}$ \\
\hline $1 / 22$ & $36 \pm 2$ & $31 \pm 4$ & $36 \pm 4$ & $52 \pm 3$ & $41 \pm 4$ & $43 \pm 5$ & $50 \pm 3$ & $40 \pm 4$ & $\overline{36 \pm 4}$ \\
\hline $1 / 29$ & $10 \pm 1$ & $11 \pm 3$ & $15 \pm 1$ & $16 \pm 2$ & $11 \pm 3$ & $25 \pm 4$ & $8 \pm 1$ & $9+3$ & $18 \pm 3$ \\
\hline $2 / 5$ & $11 \pm 1$ & $9 \pm 2$ & $20 \pm 3$ & $18 \pm 2$ & $16 \pm 3$ & $22 \pm 4$ & $16 \pm 2$ & $17 \pm 4$ & $21 \pm 3$ \\
\hline $2 / 12$ & $32 \pm 2$ & $12 \pm 3$ & $43 \pm 5$ & $38 \pm 3$ & $30 \pm 4$ & $45 \pm 7$ & $39 \pm 3$ & $26 \pm 4$ & $47 \pm 5$ \\
\hline $2 / 19$ & $10 \pm 1$ & $9 \pm 2$ & $13 \pm 3$ & $15 \pm 2$ & $13+3$ & $23 \pm 5$ & $14 \pm 2$ & $9 \pm 3$ & $11 \pm 3$ \\
\hline $2 / 26$ & $12 \pm 2$ & $12 \pm 3$ & $16 \pm 3$ & $13 \pm 2$ & $13 \pm 3$ & $18 \pm 4$ & $12 \pm 2$ & $8 \pm 3$ & $18 \pm 3$ \\
\hline $3 / 5$ & $9 \pm 1$ & $9 \pm 3$ & $11 \pm 3$ & $13 \pm 2$ & $13 \pm 3$ & $\mathrm{NS}$ & $12 \pm 2$ & $12 \pm 4$ & $13 \pm 3$ \\
\hline $3 / 12$ & $20 \pm 2$ & $16 \pm 3$ & $20 \pm 3$ & $24 \pm 2$ & NS & $19 \pm 3$ & $24 \pm 2$ & $18 \pm 4$ & $24 \pm 4$ \\
\hline $3 / 19$ & $13 \pm 1$ & $13 \pm 3$ & $16 \pm 3$ & $16 \pm 2$ & $\mathrm{NS}$ & $20 \pm 3$ & $16 \pm 2$ & $8+3$ & $15 \pm 3$ \\
\hline $3 / 26$ & $16 \pm 2$ & $16 \pm 3$ & $15 \pm 3$ & $22 \pm 2$ & $15 \pm 4$ & $18 \pm 3$ & $20 \pm 3$ & $16 \pm 4$ & $15 \pm 3$ \\
\hline $4 / 2$ & $9 \pm 1$ & $7 \pm 2$ & $16 \pm 3$ & $15 \pm 2$ & $11 \pm 3$ & $16 \pm 3$ & $11 \pm 2$ & $9 \pm 4$ & $17 \pm 3$ \\
\hline $4 / 9$ & $14 \pm 2$ & $18 \pm 3$ & $21 \pm 4$ & $21 \pm 3$ & $17 \pm 4$ & $20 \pm 4$ & $17 \pm 2$ & NS & $24 \pm 4$ \\
\hline $4 / 16$ & $\mathrm{NS}$ & $16 \pm 3$ & $33 \pm 4$ & $33 \pm 3$ & $17 \pm 3$ & $34 \pm 4$ & $32 \pm 3$ & $\mathrm{NS}$ & $36 \pm 5$ \\
\hline $4 / 23$ & $17 \pm 2$ & $17 \pm 4$ & $20 \pm 4$ & $25 \pm 2$ & $18 \pm 4$ & $26 \pm 4$ & $21 \pm 2$ & $13 \pm 4$ & $22 \pm 4$ \\
\hline $4 / 30$ & $13 \pm 2$ & $10 \pm 2$ & $16 \pm 3$ & $17 \pm 2$ & $13 \pm 3$ & $21 \pm 4$ & $16 \pm 2$ & $12 \pm 4$ & $25 \pm 4$ \\
\hline $5 / 7$ & $19 \pm 2$ & $14 \pm 3$ & $26 \pm 4$ & $26 \pm 3$ & $17 \pm 4$ & $8 \pm 3$ & $22 \pm 2$ & $16 \pm 4$ & $29 \pm 4$ \\
\hline $5 / 14$ & $30 \pm 3$ & $21 \pm 4$ & $40 \pm 5$ & $39 \pm 3$ & $30 \pm 4$ & $49 \pm 5$ & $34 \pm 3$ & $24 \pm 4$ & $41 \pm 5$ \\
\hline $5 / 21$ & $25 \pm 2$ & $18 \pm 4$ & $32 \pm 4$ & $32 \pm 3$ & NS & $32 \pm 4$ & $27 \pm 2$ & $21 \pm 4$ & $51 \pm 8$ \\
\hline $5 / 28$ & $17 \pm 2$ & $11 \pm 3$ & $17 \pm 4$ & $25 \pm 2$ & $18 \pm 4$ & $28 \pm 4$ & $20 \pm 2$ & $17 \pm 4$ & $19 \pm 4$ \\
\hline $6 / 4$ & $17 \pm 2$ & $15 \pm 3$ & $27 \pm 4$ & $22 \pm 2$ & $15 \pm 3$ & $28 \pm 4$ & $20 \pm 2$ & $23 \pm 4$ & $\overline{26 \pm 4}$ \\
\hline $6 / 11$ & $18 \pm 2$ & $13+3$ & $26 \pm 4$ & $23 \pm 2$ & $19 \pm 4$ & $25 \pm 4$ & $19 \pm 2$ & $21 \pm 4$ & $\overline{31 \pm 4}$ \\
\hline $6 / 18$ & $14 \pm 2$ & $14 \pm 3$ & $25 \pm 4$ & $24 \pm 2$ & $17 \pm 4$ & $\mathrm{NS}$ & $21 \pm 2$ & $15 \pm 4$ & $28 \pm 4$ \\
\hline $6 / 25$ & $20 \pm 2$ & $16 \pm 3$ & $25 \pm 4$ & $27 \pm 3$ & $20 \pm 4$ & $29 \pm 5$ & $24 \pm 2$ & $27 \pm 4$ & $30 \pm 5$ \\
\hline $7 / 2$ & $20 \pm 2$ & $19 \pm 3$ & $34 \pm 5$ & $29 \pm 3$ & $18 \pm 4$ & $\mathrm{NS}$ & $26 \pm 2$ & $21 \pm 4$ & $32 \pm 4$ \\
\hline $7 / 9$ & $24 \pm 2$ & $19 \pm 3$ & $35 \pm 5$ & $30 \pm 3$ & $22 \pm 4$ & $38 \pm 5$ & $28 \pm 2$ & $24 \pm 4$ & $37 \pm 5$ \\
\hline $7 / 16$ & $19 \pm 2$ & $15 \pm 3$ & $29 \pm 4$ & $25 \pm 3$ & $12 \pm 3$ & $26 \pm 6$ & $24 \pm 2$ & $22 \pm 4$ & $29 \pm 4$ \\
\hline $7 / 23$ & $29 \pm 2$ & $23 \pm 3$ & $33 \pm 4$ & $34 \pm 3$ & $25 \pm 4$ & $38 \pm 5$ & $34 \pm 3$ & $25 \pm 4$ & $34 \pm 4$ \\
\hline $7 / 30$ & $26 \pm 2$ & $23 \pm 3$ & $33 \pm 4$ & $30 \pm 3$ & $23 \pm 4$ & NS & $31 \pm 3$ & $22+4$ & $38 \pm 5$ \\
\hline $8 / 6$ & $23 \pm 2$ & $20 \pm 3$ & $39 \pm 5$ & $30 \pm 3$ & $23 \pm 4$ & NS & $27 \pm 2$ & $16 \pm 4$ & $37 \pm 5$ \\
\hline $8 / 13$ & $25 \pm 2$ & $18 \pm 3$ & $33 \pm 5$ & $29 \pm 3$ & $20 \pm 4$ & NS & $26 \pm 2$ & $24 \pm 4$ & $33 \pm 5$ \\
\hline $8 / 20$ & $25 \pm 2$ & $19 \pm 3$ & $31 \pm 4$ & $30+3$ & $26 \pm 4$ & $35+5$ & $27 \pm 3$ & $13+3$ & $33+4$ \\
\hline $8 / 27$ & $23 \pm 2$ & $17 \pm 3$ & $28 \pm 4$ & $29 \pm 3$ & $16 \pm 3$ & $30 \pm 4$ & $28 \pm 2$ & $23 \pm 4$ & $32 \pm 4$ \\
\hline $9 / 3$ & $32 \pm 2$ & $27 \pm 3$ & $36 \pm 5$ & $34 \pm 3$ & $33 \pm 4$ & NS & $34 \pm 3$ & $22 \pm 4$ & $41 \pm 5$ \\
\hline $9 / 10$ & $27 \pm 2$ & $23 \pm 3$ & $40 \pm 5$ & $28 \pm 3$ & $17 \pm 3$ & $34 \pm 4$ & $31 \pm 3$ & $27 \pm 4$ & $38 \pm 5$ \\
\hline $9 / 17$ & $18 \pm 2$ & $12 \pm 2$ & $24 \pm 4$ & NS & $17 \pm 4$ & $28+4$ & $21 \pm 2$ & $13 \pm 4$ & $27 \pm 4$ \\
\hline$9 \longdiv { 2 4 }$ & $19 \pm 2$ & $16 \pm 2$ & $32 \pm 4$ & $23 \pm 3$ & $17 \pm 3$ & $32 \pm 5$ & $24 \pm 2$ & $22+4$ & $\overline{31 \pm 4}$ \\
\hline $10 / 1$ & $25 \pm 2$ & $22 \pm 3$ & $35 \pm 5$ & $28+3$ & $27 \pm 4$ & $42 \pm 5$ & $32 \pm 2$ & $28 \pm 6$ & $\overline{34 \pm 5}$ \\
\hline $10 / 8$ & $16 \pm 2$ & $13 \pm 3$ & $16 \pm 4$ & $21+3$ & $18 \pm 3$ & $17 \pm 4$ & $21 \pm 2$ & $18 \pm 4$ & $18+7$ \\
\hline $10 / 15$ & $14 \pm 2$ & $15 \pm 3$ & $22 \pm 4$ & $17 \pm 2$ & $17 \pm 3$ & $32 \pm 4$ & $19 \pm 2$ & $7 \pm 3$ & $\overline{\mathrm{NS}}$ \\
\hline $10 / 22$ & $40 \pm 3$ & $30 \pm 4$ & $60 \pm 6$ & $46 \pm 3$ & $33 \pm 4$ & $66 \pm 6$ & $47 \pm 3$ & $36 \pm 6$ & $\overline{70 \pm 7}$ \\
\hline $10 / 29$ & $31 \pm 3$ & $24 \pm 4$ & $37 \pm 5$ & $41 \pm 3$ & $39 \pm 4$ & $47 \pm 5$ & $42 \pm 3$ & $35 \pm 6$ & $46 \pm 5$ \\
\hline $11 / 5$ & $20 \pm 2$ & $14 \pm 3$ & $28 \pm 4$ & $26 \pm 2$ & $28+4$ & $\overline{\mathrm{NS}}$ & $28 \pm 2$ & $18 \pm 4$ & $27 \pm 4$ \\
\hline $11 / 12$ & $32 \pm 3$ & $22+3$ & $45 \pm 5$ & $33 \pm 2$ & $33 \pm 4$ & $47 \pm 5$ & $41 \pm 3$ & $25 \pm 4$ & $36 \pm 5$ \\
\hline $11 / 19$ & $40 \pm 3$ & $32 \pm 4$ & $65 \pm 4$ & $56 \pm 3$ & $48 \pm 4$ & $79 \pm 4$ & $53 \pm 3$ & $23 \pm 4$ & $76 \pm 4$ \\
\hline $11 / 25$ & $15 \pm 2$ & $10 \pm 2$ & $18 \pm 2$ & $15 \pm 2$ & $13 \pm 3$ & $22 \pm 2$ & $18 \pm 2$ & $15 \pm 4$ & $23 \pm 2$ \\
\hline $12 / 3$ & $19 \pm 2$ & $17 \pm 3$ & $32 \pm 3$ & $26 \pm 2$ & $28+4$ & $45 \pm 3$ & $27 \pm 2$ & $23 \pm 4$ & $40 \pm 3$ \\
\hline $12 / 10$ & $26+2$ & $20 \pm 3$ & $\mathrm{NS}$ & $34 \pm 2$ & $30 \pm 4$ & $60 \pm 4$ & $34+3$ & $24 \pm 4$ & $55 \pm 3$ \\
\hline $12 / 17$ & $22 \pm 2$ & $21 \pm 3$ & NS & $38 \pm 3$ & $32 \pm 4$ & $57 \pm 3$ & $33 \pm 3$ & $30 \pm 6$ & $49 \pm 3$ \\
\hline $\mathrm{I} 2 / 23$ & $14 \pm 2$ & $13 \pm 3$ & $32 \pm 3$ & $22 \pm 2$ & $21 \pm 4$ & $48 \pm 3$ & $25 \pm 2$ & $16 \pm 4$ & $44 \pm 3$ \\
\hline $12 / 31$ & $16 \pm 2$ & $14 \pm 2$ & $22 \pm 2$ & $28 \pm 2$ & $28+3$ & $42+3$ & $19 \pm 3$ & $21 \pm 2$ & $40 \pm 3$ \\
\hline
\end{tabular}




\begin{tabular}{|c|c|c|c|c|c|c|c|}
\hline \multirow[b]{3}{*}{ Location } & \multicolumn{7}{|c|}{$\begin{array}{l}\text { TABLE 9-8. COMPARISON OF FOUNDATION AND STATE OF IDAHO } \\
\text { WATER MONITORING RESULTS (1997) }\end{array}$} \\
\hline & \multirow[b]{2}{*}{ Date } & \multicolumn{2}{|c|}{$\begin{array}{c}\text { Gross Alpha } \\
\left(10^{-9} \mu \mathrm{Ci} / \mathrm{mL}\right)^{\mathrm{a}}\end{array}$} & \multicolumn{2}{|c|}{$\begin{array}{c}\text { Gross Beta } \\
\left(10^{-9} \mu \mathrm{Ci} / \mathrm{mL}\right)^{\mathrm{a}}\end{array}$} & \multicolumn{2}{|c|}{$\begin{array}{c}\text { Tritium } \\
\left(10^{-9} \mu \mathrm{Ci} / \mathrm{mL}\right)^{a}\end{array}$} \\
\hline & & Foundation & State & Foundation & State & Foundation & State \\
\hline \multirow{4}{*}{$\begin{array}{c}\text { Minidoka } \\
\text { (Drinking } \\
\text { Water) }\end{array}$} & $02 / 97$ & $0 \pm 1$ & $1 \pm 3$ & $4 \pm 3$ & $6 \pm 3$ & $12 \pm 113$ & $-20+90$ \\
\hline & $05 / 97$ & $1 \pm 2$ & $1 \pm 8$ & $6 \pm 3$ & $5+3$ & $80 \pm 80$ & $30 \pm 100$ \\
\hline & $08 / 97$ & $0 \pm 1$ & $2 \pm 2$ & $3 \pm 2$ & $3 \pm 2$ & $14 \pm 100$ & $120 \pm 100$ \\
\hline & $11 / 97$ & $0+1$ & $3 \pm 5$ & $4+2$ & $4+3$ & $-80+100$ & $30 \pm 90$ \\
\hline \multirow{4}{*}{$\begin{array}{c}\text { Shoshone } \\
\text { (Drinking } \\
\text { Water) }\end{array}$} & $02 / 97$ & $0 \pm 2$ & $0 \pm 3$ & $4 \pm 2$ & $6+3$ & $52+56$ & $80 \pm 100$ \\
\hline & $05 / 97$ & $0 \pm 1$ & $4 \pm 8$ & $5 \pm 2$ & $5 \pm 3$ & $90 \pm 80$ & $30+100$ \\
\hline & $08 / 97$ & $0 \pm 1$ & $4+6$ & $2+2$ & $4 \pm 2$ & $-47+100$ & $60 \pm 100$ \\
\hline & $11 / 97$ & $0 \pm 1$ & $-2+5$ & $2+2$ & $5 \pm 3$ & $40 \pm 100$ & $30 \pm 90$ \\
\hline \multirow{4}{*}{$\begin{array}{c}\text { Bill Jones } \\
\text { Hatchery } \\
\text { (Surface } \\
\text { Water) }\end{array}$} & $02 / 97$ & $0 \pm 1$ & $1 \pm 2$ & $3 \pm 2$ & $6 \pm 2$ & $30 \pm 110$ & $0 \pm 90$ \\
\hline & $05 / 97$ & $0+1$ & $-6 \pm 5$ & $4 \pm 2$ & $6 \pm 3$ & $70 \pm 80$ & $-10 \pm 100$ \\
\hline & $08 / 97$ & $0 \pm 1$ & $1 \pm 6$ & $3+2$ & $2+2$ & $-35+100$ & $10 \pm 100$ \\
\hline & $11 / 97$ & $\overline{0 \pm 1}$ & $-2 \pm 5$ & $4+2$ & $6+3$ & $-10+100$ & $10 \pm 90$ \\
\hline \multirow{4}{*}{$\begin{array}{l}\text { Clear } \\
\text { Springs } \\
\text { (Surface } \\
\text { Water) }\end{array}$} & $02 / 97$ & $0 \pm 1$ & $0 \pm 3$ & $6+2$ & $6 \pm 3$ & $30 \pm 110$ & $40 \pm 100$ \\
\hline & $05 / 97$ & $0 \pm 1$ & $5 \pm 9$ & $4 \pm 2$ & $7 \pm 3$ & $-10 \pm 80$ & $-65 \pm 100$ \\
\hline & $08 / 97$ & $0 \pm 1$ & $2 \pm 7$ & $5+2$ & $4+3$ & $14 \pm 100$ & $90 \pm 100$ \\
\hline & $11 / 97$ & $0+1$ & $1 \pm 7$ & $4 \pm 2$ & $7 \pm 4$ & $30 \pm 100$ & $10 \pm 90$ \\
\hline \multirow{4}{*}{$\begin{array}{l}\text { Alpheus } \\
\text { Spring } \\
\text { (Surface } \\
\text { Water) }\end{array}$} & $02 / 97$ & $0 \pm 2$ & $2 \pm 4$ & $7 \pm 3$ & $9 \pm 3$ & $37 \pm 93$ & $60 \pm 100$ \\
\hline & $05 / 97$ & $0 \pm 2$ & $-1+4$ & $8+3$ & $10 \pm 3$ & $70 \pm 80$ & $30 \pm 100$ \\
\hline & $08 / 97$ & $0 \pm 1$ & $1 \pm 9$ & $7 \pm 2$ & $8+3$ & $35 \pm 100$ & $20 \pm 100$ \\
\hline & $11 / 97$ & $\overline{0+1}$ & $-6 \pm 7$ & $12 \pm 4$ & $9 \pm 3$ & $30+100$ & $70 \pm 90$ \\
\hline
\end{tabular}




\section{APPENDIX A ENVIRONMENTAL STANDARDS AND REGULATIONS}

The following environmental standards and regulations are applicable, in whole or in part, on the INEEL or at the INEEL boundary.

U.S. Environmental Protection Agency, "National Primary and Secondary Ambient Air Quality Standards;" 40 CFR 50, 1997.

U.S. Environmental Protection Agency, "National Emission Standards for Hazardous Air Pollutants," 40 CFR 61, 1997.

U.S. Environmental Protection Agency, "National Pollutant Discharge Elimination System," 40 CFR 122, 1997.

U.S. Environmental Protection Agency, "National Interim Primary Drinking Water Regulations," 40 CFR 141, 1997.

U.S. Environmental Protection Agency, "Hazardous Waste Management System: General," 40 CFR 260, 1997.

U.S. Environmental Protection Agency, "Identifying and Listing of Hazardous Wastes," 40 CFR 261, 1997.

U.S. Environmental Protection Agency, "Standards Applicable to Generators of Hazardous Waste," 40 CFR 262, 1997.

U.S. Environmental Protection Agency, "Standards Applicable to Transporters of Hazardous Waste," 40 CFR 263, 1997.

U.S. Environmental Protection Agency, "Standards for Owners and Operators of Hazardous Waste Treatment, Storage and Disposal Facilities," 40 CFR 264, 1997.

U.S. Environmental Protection Agency, "Interim Status Standards for Owners and Operators of Hazardous Waste Treatment, Storage and Disposal Facilities," 40 CFR 265, 1997.
U.S. Environmental Protection Agency, "Interim Standards for Owners and Operators of New Hazardous Waste Land Disposal Facilities," 40 CFR 267, 1997.

Department of Health and Welfare, State of Idaho, "Rules and Regulations for the Control of Air Pollution in Idaho," 1972, as amended through May 1990.

Department of Health and Welfare, State of Idaho, "Idaho Regulations for Public Drinking Water Systems," 16.01.8000-16.01.8999, October 1993.

The Derived Concentration Guides (DCGs) are based on the DOE standard [Reference A-1] and have been calculated using DOE models and parameters for internal [Reference A-2] and external [Reference A-3] exposure. These are shown in Table A-1. The most restrictive guide is listed when there is a difference between the soluble and insoluble chemical forms. The DCGs consider only the inhalation of air, the ingestion of water, and submersion in air. The principal standards and guides for release of radionuclides at the INEEL are those of DOE Order 5400.5, entitled "Radiation Protection of the Public and the Environment." The DOE standard is shown in Table A-2 along with the EPA standard for protection of the public, airborne pathway only.

Ambient air quality standards are shown in Table A-3. Water quality standards are dependent on the type of drinking water system sampled. Table A-4 is a partial list of maximum contaminant levels set by the EPA for public community drinking water systems in 40 CFR 141. 


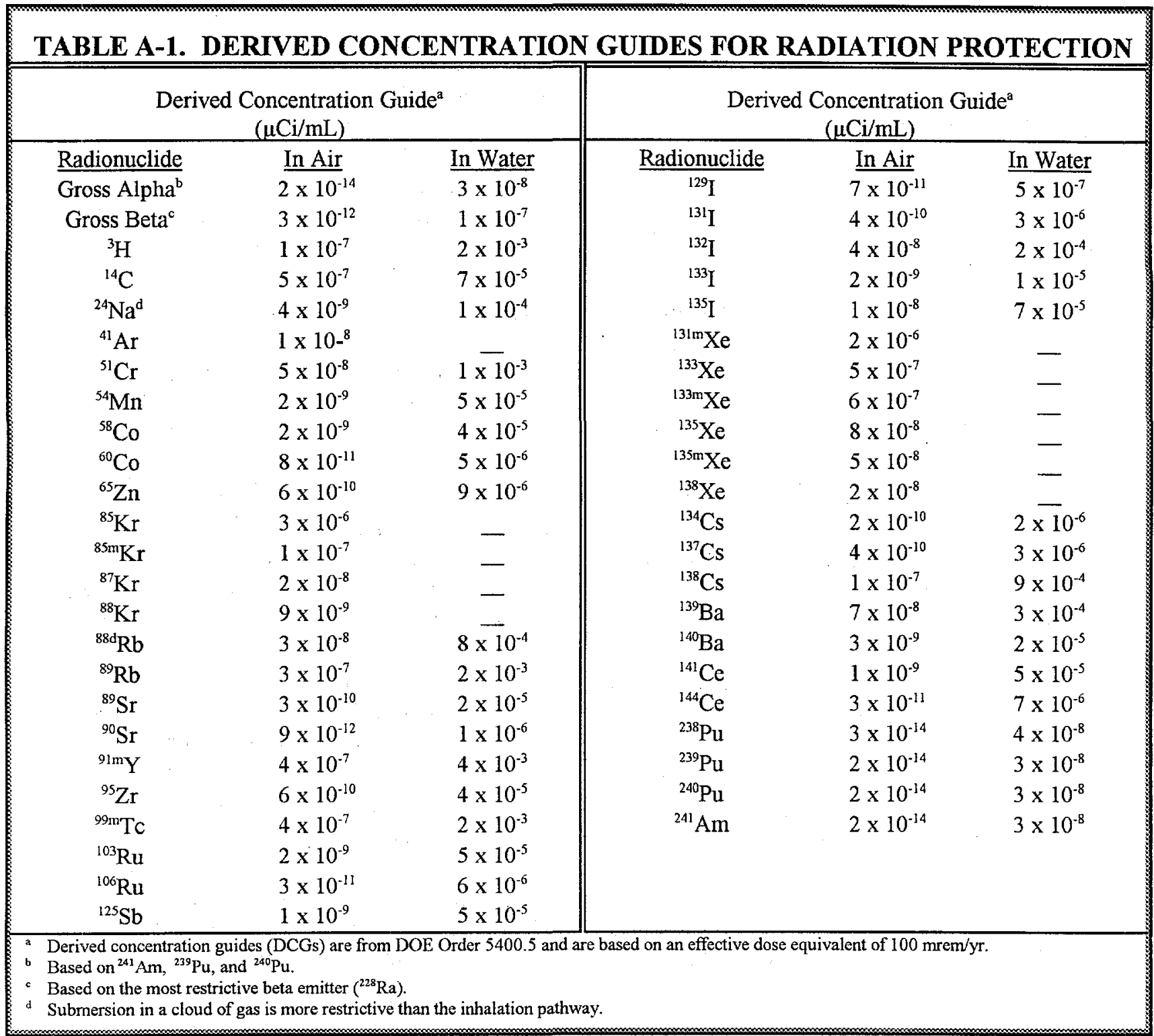


TABLE A-2. RADIATION STANDARDS FOR PROTECTION OF THE PUBLIC IN THE VICINITY OF DOE FACILITIES

\begin{tabular}{|c|c|c|}
\hline & \multicolumn{2}{|c|}{ Effective Dose Equivalent } \\
\hline & mrem/yr & $\underline{\mathrm{mSv} / \mathrm{yr}}$ \\
\hline $\begin{array}{l}\text { DOE Standard for routine DOE activities } \\
\text { (all pathways) }\end{array}$ & 100 & 1 \\
\hline $\begin{array}{l}\text { EPA Standard for site operations } \\
\text { (airborne pathway only) }\end{array}$ & 10 & 0.1 \\
\hline
\end{tabular}

\begin{tabular}{|c|c|c|c|}
\hline \multicolumn{4}{|c|}{ TABLE A-3. EPA AMBIENT AIR QUALITY STANDARDS } \\
\hline Pollutant & Type of $\underline{\text { Standard }}^{\mathrm{a}}$ & Sampling Period & $\underline{\operatorname{EPA}\left(\mu \mathrm{g} / \mathrm{m}^{3}\right)^{\mathrm{b}}}$ \\
\hline $\mathrm{SO}_{2}$ & $\mathrm{~S}$ & 3-hour average & 1300 \\
\hline \multirow{4}{*}{$\mathrm{NO}_{2}$} & $\mathrm{P}$ & 24-hour average & 365 \\
\hline & $\mathrm{P}$ & Annual average & 80 \\
\hline & S\&P & Annual average & 100 \\
\hline & $\mathrm{S}$ & 24-hour average & 150 \\
\hline Total Particulates ${ }^{\mathrm{c}}$ & $\mathrm{S} \& \mathrm{P}$ & Annual average & 50 \\
\hline \multicolumn{4}{|c|}{$\begin{array}{l}\text { National primary (P) ambient air quality standards define levels of air quality to protect the public health. Secondary (S) ambient air quality } \\
\text { standards define levels of air quality to protect the public welfare from any known or anticipated adverse effects of a pollutant. } \\
\text { The State of Idaho has adopted these same ambient air quaiity standards. } \\
\text { - The primary and secondary standard to the annual average applies only to "particulates with an aerodynamic diameter less than or equal to a } \\
\text { nominal } 10 \text { micrometers." }\end{array}$} \\
\hline
\end{tabular}




\begin{tabular}{|c|c|}
\hline \multicolumn{2}{|c|}{$\begin{array}{l}\text { TABLE A-4. EPA MAXIMUM CONTAMINANT LEVELS FOR } \\
\text { NONTRANSIENT NONCOMMUNITY DRINKING WATER } \\
\text { SYSTEMS }\end{array}$} \\
\hline Gross alpha & $1.5 \times 10^{-8} \mu \mathrm{Ci} / \mathrm{mL}$ \\
\hline Gross beta & $5.0 \times 10^{-8} \mu \mathrm{Ci} / \mathrm{mL}$ \\
\hline Manmade radionuclides & $\begin{array}{l}\text { Concentrations resulting in } 4 \mathrm{mrem} \text { total } \\
\text { body or organ dose equivalent }\end{array}$ \\
\hline Nitrate (as N) & $10 \mathrm{mg} / \mathrm{L}$ \\
\hline Fluoride & $4 \mathrm{mg} / \mathrm{L}$ \\
\hline Trihalomethanes (Chloroform) & $0.1 \mathrm{mg} / \mathrm{L}$ \\
\hline Carbon Tetrachloride & $0.005 \mathrm{mg} / \mathrm{L}$ \\
\hline Tetrachloroethylene & $0.005 \mathrm{mg} / \mathrm{L}$ \\
\hline Toluene & $1.0 \mathrm{mg} / \mathrm{L}$ \\
\hline 1,1,1-trichloroethane & $0.2 \mathrm{mg} / \mathrm{L}$ \\
\hline Trichloroethylene & $0.005 \mathrm{mg} / \mathrm{L}$ \\
\hline Arsenic & $0.05 \mathrm{mg} / \mathrm{L}$ \\
\hline Barium & $2 \mathrm{mg} / \mathrm{L}$ \\
\hline Cadmium & $0.005 \mathrm{mg} / \mathrm{L}$ \\
\hline Chromium & $0.1 \mathrm{mg} / \mathrm{L}$ \\
\hline Lead & $0.05 \mathrm{mg} / \mathrm{L}$ \\
\hline Mercury & $0.002 \mathrm{mg} / \mathrm{L}$ \\
\hline Selenium & $0.05 \mathrm{mg} / \mathrm{L}$ \\
\hline Silver & $0.05 \mathrm{mg} / \mathrm{L}$ \\
\hline
\end{tabular}




\section{APPENDIX B \\ STATISTICAL METHODS USED \\ FOR THE ENVIRONMENTAL SURVEILLANCE PROGRAM}

Relatively simple statistical procedures are used to analyze the data from the INEEL environmental surveillance program. Environmental surveillance program personnel initially review field collection information and analytical results to determine whether there are identifiable errors that would invalidate or limit the use of the results. Examples of these might be power outages at air sampler locations, torn membrane filters, or evidence of laboratory cross-contamination. Data that pass this initial screening are then evaluated for statistical significance with respect to laboratory analytical uncertainties, sample locations, reported releases from INEEL operations, meteorological data, and worldwide events that might conceivably have an effect on the INEEL environment.

For radiological data, individual analytical results are presented in this report with plus or minus $( \pm)$ two analytical standard deviations (2s), where all analytical uncertainties have been estimated, and "s" is an estimate of the population standard deviation " $\sigma$." Many of the results were less than or equal to $2 \mathrm{~s}$ (and, in fact, some were negative), which means that they were below the minimum detectable concentration. For example, in gamma spectro-metric analyses, a given radionuclide is not considered detected unless the net count in the peak is greater than three times its estimated analytical uncertainty (3s). If the result lies in the range of two to three times its estimated analytical uncertainty ( $2 \mathrm{~s}$ to $3 \mathrm{~s}$ ), and assuming that the result belongs to a Gaussian distribution, detection of the material by the analysis may be questionable because of statistical variations within the group of samples. If the result exceeds $3 \mathrm{~s}$, there is confidence that the material was detected (or, that the radionuclide was present in the sample).

A deliberate search for specific nuclides can be made and results reported, but such results might include negative values or small positive values where the result is less than or equal to $2 \mathrm{~s}$.
Analyses with results in the questionable range (2s to $3 \mathrm{~s}$ ) are published in this report with the understanding that there is some doubt as to whether the material was actually present.

There are many factors that can influence the result to some degree, and these factors are considered and included in the methods used to determine the estimated uncertainty of the measurement. Uncertainties in measurements near the minimum detectable concentration are primarily caused by counting statistics. For low concentrations near the minimum detectable concentration, the uncertainty in the measurement is nearly equal to the measurement itself, and the lower limit of the range of the measurement approaches "zero." Such a result might not be very reliable because the uncertainty is only an estimate and the actual probability distribution of the results is not usually known. In reality, the material being measured may not actually be present in the sample. Therefore, when analytical results show a measurement very near the minimum detectable concentration, statistical tools, meteorological data, and Site release information are all considered when interpreting and evaluating the results.

Arithmetic means were calculated using actual assay results, regardless of their being above or below the minimum detectable concentration. The uncertainty of the mean, or the $95 \%$ confidence interval, was determined by multiplying the standard deviation of the mean (also called the standard error of the mean) or $s /(n)^{1 / 2}$ by the $t_{(0.05)}$ statistic. Means for which the $95 \%$ confidence interval does not include zero were assumed to indicate detectable amounts of activity. In situations where the analytical results of a group of samples are near the minimum detectable concentration, the $95 \%$ confidence interval for the mean may not include zero and thus appears to be statistically significant even though, on the basis of the $2 \mathrm{~s}$ to $3 \mathrm{~s}$ criterion, it is doubtful that any individual sample contained detectable radioactivity. 
Geometric means were calculated by summing the natural logarithms (In) of the positive analytical results, dividing by the number of samples (n), and then transforming the quotient. If the result was either a negative number or a zero, the $\ln$ of the smallest positive, nonzero measurement in the group was used. The $95 \%$ confidence interval was determined by multiplying the standard deviation of the geometric mean by the $t_{(0.05)}$ statistic and then transforming the result. The actual interval is determined by dividing the transformed mean by the transformed $95 \%$ confidence interval term for the lower limit, then multiplying the mean by the confidence interval term for the upper limit.

Unpaired t-tests were used to determine whether the annual means for the INEEL or boundary stations were greater than the annual means for the distant stations. All statistical tests used a level of significance of $5 \%(\alpha=0.05)$. 


\section{REFERENCES}

Number

P-1 National Council on Radiation Protection and Measurements, Ionizing Radiation Exposure of the Population of the United States, NCRP Report No. 93, September 1, 1987.

P-2

U.S. Department of Energy Order 5400.1, General Environmental Protection Program, November 9, 1988.

Department of Energy National Environmental Research Parks, DOE/ER-0615P, July 1994.

Climatography of the Idaho National Engineering Laboratory, 2nd Edition, DOE/ID12118, December 1989.

Anderson, J.E., Ruppel, K.T., Glennon, J.M., Holte, K.E., and Rope, R.C., Plant Communities, Ethnoecology, and Flora of the Idaho National Engineering Laboratory, ESRF-005, June 1996.

Arthur, W.J., Connelly, J.W., Halford, D.K., and Reynolds, T.D., Vertebrates of the Idaho National Engineering Laboratory, DOE/ID-12099, July 1984.

Idaho National Engineering Laboratory Comprehensive Facility \& Land Use Plan, DOE/ID-10514,December 1997.

Idaho National Environmental Research Park, INEL BP499-R1091-1M-T, no date

Lindholm, G.F., Summary of the Snake River Plain Regional Aquifer-System Analysis in Idaho and Eastern Oregon, U.S. Geological Survey Professional Paper 1408-A, 1996.

The Site, the Plain, the Aquifer, and the Magic Valley (Part One of Four), Foundation Focus, Volume 3, Issue 3, October 1996.

U.S. Department of Energy Idaho Operations Office 1997 Annual Report, No Date.

Idaho 1996 Official Highway Map, Idaho Transportation Department.

VanHorn, R.L., Hampton, N.L., and Morris, R.C., Guidance Manual for Conducting Screening Level Ecological Risk Assessments at the INEL, INEL-95/0190, June 1995.

DOE, Natural Resource Trusteeship and Ecological Evaluation for Environmental Restoration at Department of Energy Facilities, DOE/EH-0192, June 1991.

Sagendorf, J.F., Precipitation Frequency and Intensity at the Idaho National Engineering

Laboratory, NOAA Technical Memorandum ERL ARL-215, September 1996. 


\section{REFERENCES (Cont.)}

Number

\section{Reference}

U.S. Environmental Protection Agency, 40 CFR 261.4, Treatability Studies, 1996.

Reynolds, T.D., and Warren, R.W., Environmental Science and Research Foundation Annual Technical Report to DOE-ID, Calendar Year 1997, ESRF-027.

Frederick, D.B. and Johnson, G., Estimation of Hydraulic Properties and Development of a Layered Conceptual Model for the Snake River Plain Aquifer at the Idaho National Engineering Laboratory, Idaho.

McCurry, M. and Welhan, J., Summary of Analytical Results for Hydrologic Studies of Wells Open through Large Intervals of the Snake River Plain Aquifer at the Idaho National Engineering Laboratory.

Agreement to Resolve Disputes, Docket No. 1088-06-29-120, March 18, 1997.

Remedial Design/Remedial Action Scope of Work and Remedial Design Work Plan: Operable Unit 7-10 (Pit 9 Project Interim Action)," October 1997, Revision 2, Document \# INEL-94/0110.

Over 2,000 Unexploded Ordnance Removed From the Idaho National Engineering and Environmental Laboratory (INEEL), 97-561-1-28

U.S. Environmental Protection Agency, Compilation of Air Pollutant Emission Factors, AP-42, Part A, August 1982; pp. 1.3-2.

State of Idaho INEEL Oversight Program Environmental Surveillance Report 1996.

U.S. Environmental Protectión Agency, Environmental Radiation Data Reports 79-82, July 1994 - June 1995.

Yoder, R.C., et al., Confirmation of Conversion Factors Relating Exposure and DoseEquivalent Index Presented in ANSI N13.11, NUREG/CR-1057, PNL-3219: Pacific Northwest Laboratory, Richland, WA, 1979.

National Council on Radiation Protection and Measurements, Exposure of the Population in the United States and Canada from Natural Background Radiation, NCRP Report No. 94, December 30, 1987.

U.S. Environmental Protection Agency, National Primary and Secondary Ambient Air Quality Standards for Particulate Matter, 40 CFR 50.6, 1996.

U.S. Environmental Protection Agency, National Primary Ambient Air Quality Standards for Nitrogen Oxides, 40 CFR 50.4 and National Secondary Ambient Air Quality 


\section{REFERENCES (Cont.)}

Number

\section{Reference}

Standards for Sulfur Oxides, 40 CFR 50.5, 1996.

Annual Report, Aerosol Collection and Compositional Analysis for IMPROVE, July 1993-June 1994, Air Quality Group, Crocker Nuclear Laboratory.

"Final National Pollutant Discharge Elimination System Storm Water Multi-Sector General Permit for Industrial Activities; Notice, Federal Register, Vol. 60, No. 189, p. 50826, Sept. 29, 1995.

Bartholomay, R.C., Tucker, B.J., Ackerman, D.J., and Liszewski, M.J., Hydrologic Conditions and Distribution of Selected Radiochemical and Chemical Constituents in Water, Snake River Plain Aquifer, Idaho National Engineering Laboratory, Idaho, 1992 through 1995, U.S. Geological Survey, Water-Resources Investigation Report 97-4086, DOE/ID-22137, April 1997.

Bartholomay, R.C., Williams, L.M., U.S. Geological Survey, and Campbell, L.J., Idaho Department of Water Resources, Evaluation of Radionuclide, Inorganic Constituent, and Organic Compound Data from Selected Wells and Springs from the Southern Boundary of the Idaho National Engineering Laboratory to the Hagerman Area, Idaho, 1989 through 1992; Water Resources Investigation Report 97-4007, DOE/ID-22133, January 1997.

Berenbrock, C. and Kjelstrom, L.C., Simulation of Water-Surface Elevations for a Hypothetical 100-Year Peak Flow in Birch Creek at the Idaho National Engineering and Environmental Laboratory, Idaho; Water Resources Investigations Report 97-4083, DOE/ID-22138, 1997.

Knobel, L.L., Bartholomay, R.C., and Orr, B.R., Preliminary Delineation of Natural Geochemical Reactions, Snake River Plain Aquifer System, Idaho National Engineering Laboratory and Vicinity, Idaho; Water-Resources Investigations Report 97-4093, DOE/ID-22139, May 1997.

Liszewski, M.J., U.S. Geological Survey; Jeffrey J. Rosentreter, Idaho State University; and Kevin E. Miller, U.S. Geological Survey; Strontium Distribution Coefficients of Surficial Sediment Samples from the Idaho National Engineering Laboratory, Idaho; Water Resources Investigations Report 97-4044, DOE/ID-22140, May 1997.

Bartholomay R.C., and Williams, L.M., U.S. Geological Survey, and Campbell, L.J., Idaho Department of Water Resources, Radiochemical and Chemical Constituents in Water from Selected Wells and Springs from the Southern Boundary of the Idaho National Engineering Laboratory to the Hagerman Area, Idaho, 1996; USGS OpenFile Report 97-360, DOE/ID-22141, June 1997.

Anderson, S.R., and Liszewski, M.J., Stratigraphy of the Unsaturated Zone and the Snake 


\section{REFERENCES (Cont.)}

Number

$6-8$

6-10

$6-11$

$6-12$

$6-13$

$6-14$

$6-15$

$7-1$

\section{Reference}

River Plain Aquifer at and near the Idaho National Engineering Laboratory, Idaho; Water Resources Investigations Report 97-4183, DOE/ID-22142, August 1997.

Anderson, S.R. Ackerman, D.J., and Liszewski, M.J., Stratigraphic Data for Wells at and near the Idaho National Engineering Laboratory, Idaho; DOE/ID-22127; USGS Open-File Report 96-248; May 1996.

Bartholomay, R.C., Knobel, L.L., and Tucker, B.J., Chemical and Radiochemical Constituents in Water from Wells in the Vicinity of the Naval Reactors Facility, Idaho National Engineering Laboratory, Idaho, 1994-95; USGS Open-File Report 97-806, DOE/ID-22143, December 1997.

Liszewski M.J., and Mann, L.J., Purgeable Organic Compounds in Ground Water at the Idaho National Engineering Laboratory, Idaho--1990 and 1991, DOE/ID-22104, USGS Open-File Report 92-174, July 1992.

Bartholomay, R.C., Tucker, B.J., Ackerman, D.J., and Liszewski, M.J., Hydrologic Conditions and Distribution of Selected Radiochemical and Chemical Constituents in Water, Snake River Plain Aquifer, Idaho National Engineering Laboratory, Idaho, 1989 through 1991, U.S. Geological Survey, Water-Resources Investigation Report 95-4175, DOE/ID-22123, August 1995.

Orr, B.R., and Cecil, L.D., Hydrologic Conditions and Distribution of Selected Radiochemical and Chemical Constituents in Water, Snake River Plain Aquifer, Idaho National Engineering Laboratory, Idaho, 1986 through 1988, U.S. Geological Survey, Water-Resources Investigation Report 91-4047, DOE/ID-22096, 1991.

Bartholomay, R.C., Williams, L.M., and Campbell, L.J., Radionuclides, Stable Isotopes, Inorganic Constituents, and Organic Compounds in Water from Selected Wells and Springs from the Southern Boundary of the Idaho National Engineering Laboratory to the Hagerman Area, Idaho, 1995; DOE/ID-22130; USGS Open-File Report 96-496; September 1996.

Mann, L.J., Purgeable Organic Compounds in Ground Water at the Idaho National Engineering Laboratory, Idaho--1988 and 1989, DOE/ID-22089, USGS Open-File Report 90-367, July 1990.

Tucker B.J., Knobel, L.L., and Bartholomay, R.C., Chemical Constituents in Water from Wells in the Vicinity of the Naval Reactors Facility, Idaho National Engineering Laboratory, Idaho, 1991-93. DOE/ID-22125; USGS Open-File Report 95-725; November 1995.

1997 INEEL National Emissions Standard for Hazardous Air Pollutants - Radionuclides, 


\section{REFERENCES (Cont.)}

Number

Reference

DOE/ID-10342(97), June 1998.

7-2 Whicker, F.W. and Schultz, V., Radioecology: Nuclear Energy and the Environment, Volume 1, CRC Press, 1982.

Air Emissions Inventory for the Idaho National Engineering Laboratory-1997 Emissions Report, DOE/ID-10594, June 1998.

U.S. Environmental Protection Agency, Toxicity Characteristic, 40 CFR 261.24, 1996.

8-1 Start, G.E., and Wendell, L.L., Regional Effluent Dispersion Calculations Considering Spatial and Temporal Meteorological Variations, NOAA Technical Memorandum ERL ARL-44, May 1974.

U.S. Department of Energy, Internal Dose Conversion Factors for Calculation of Dose to the Public, DOE/EH-0071, July 1988.

8-3 U.S. Department of Energy, External Dose Conversion Factors for Calculation of Dose to the Public, DOE/EH-0070, July 1988.

8-4 Hoff, D.L., Chew, E.W., and Rope, S.K., 1986 Environmental Monitoring Program Report for the Idaho National Engineering Laboratory Site, DOE/ID-12082(86), May 1987.

Hoff, D.L, Chew, E.W., and Rope, S.K., 1986 Environmental Monitoring Program for the Idaho National Engineering Laboratory Site, DOE/ID-12082(86), May 1987.

8-6 Chew, E.W., and Mitchell, R.G., 1987 Environmental Monitoring Program Report for the Idaho National Engineering Laboratory Site, DOE/ID-12082(87), May 1988.

Hoff, D.L., Mitchell, R.G., and Moore, Richard, 1988 Environmental Monitoring Program Report for the Idaho National Engineering Laboratory Site, DOE/ID-12082(88), June 1989.

Halford, D.K., Markham, O.D., and White, G.C., Biological Elimination of Radioisotopes by Mallards Contaminated at a Liquid Radioactive Waste Disposal Area, Health Physics, 45 , pp. $745-756$.

Halford, D.K., Millard, J.B., and Markham, O.D., Radionuclide Concentrations in Waterfowl Using a Liquid Radioactive Disposal Area and the Potential Radiation Dose to Man, Health Physics, 40, February 1981, pp. 173-181. 


\section{REFERENCES (Cont.)}

Number

8-10

$8-11$

8-12

$8-13$

A-1

A-2

A-3

Reference

Morris, R.C., The Implications of Lined Radioactive Waste Ponds for Waterfowl Contamination, Environmental Health Physics: Proceedings of the Twenty-sixth Midyear Topical Meeting of the Health Physics Society, R.L. Kathren et al., eds., pp. 147-155.

Markham, O.D. and Halford, D.K., Radionuclides in Mourning Doves Near a Nuclear Facility Complex in Southeastern Idaho, The Wilson Bulletin, 94, 2, June 1982, pp. 185195.

Markham, O.D. and Halford, D.K., Effects of Decreased Effluents from Nuclear Fuel Reprocessing on Cs-137 Concentrations in Wildlife, Northwest Science, 59, 3, August 1985.

Connelly, J.W. and Markham, O.D., Movements and Radionuclide Concentrations of Sage Grouse in Southeastern Idaho, Journal of Wildlife Management, 47, 1, January 1983, pp. 169-175.

U.S. Department of Energy Order 5400.5, Radiation Protection of the Public and the Environment, January 7, 1993.

U.S. Department of Energy, Internal Dose Conversion Factors for Calculation of Dose to the Public, DOE/EH-0071, July 1988.

U.S. Department of Energy, External Dose Conversion Factors for Calculation of Dose to the Public, DOE/EH-0070, July 1988. 